Consortium for Economic Policy Researchand Advice

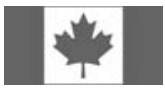

Canadian International Development Agency

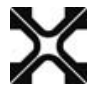

Association of Universities and Colleges of Canada
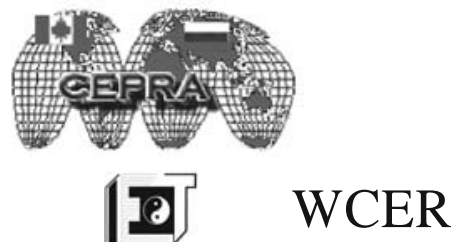

Institute of Economy

Working

Center

in Transition
Academy

of National

Economy

\title{
The institution of bankruptcy: development, problems, areas of reforming
}


UDC $658.16+347.736$

BBC 65.290-93+67.404

T44

The institution of bankruptcy: development, problems, areas of reforming. M.: IET, 2005. P. 281.

Agency CIP RSL

Authors: Radygin A.D. (Team Leader), Gontmakher A.E., Kuzyk M.G., Mezheraups I.V., Swain H., Simachiov Yu. V., Shmeleva N.A., Entov R. M.

The research focuses on the analysis of the emergence of the institution of bankruptcy (insolvency) in Russia. More specifically, it centers on studying the evaluation of its legal base, specific purposes of its use in the national transition economy, motives and objects of application of the given procedures and development of the respective country-specific recommendations. While analyzing theoretical approaches to the problem of bankruptcy, the authors focus on market financial regulation mechanisms, forms and options of bankruptcy procedures, as well as evaluation of first results of application of the new, 2002-2004, Russian law. In parallel with the analysis of the Canadian experiences in the area of corporate bankruptcy, the authors consider economic fundamentals of bankruptcy and provide a review of the contemporary legal and law enforcement systems in this particular area.

JEL Classification: G33, G38, P2, P31

Editors: Moldavsky A., Serianova S.

Page setting: $V$. Yudichev

The research and the publication were undertaken in the framework of CEPRA (Consortium for Economic Policy, Research and Advice) project funded by the Canadian Agency for International Development (CIDA).

ISBN 5-93255-162-3

5, Gazetny per., Moscow, 103918 Russia

Tel. (095) 229-6736, Fax (095) 203-8816

E-MAIL - info@iet.ru, WEB Site - http://www.iet.ru 


\section{Content}

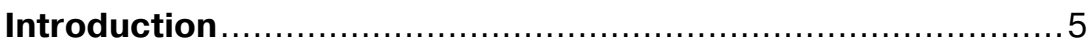

Chapter 1. The problems of bankruptcy:

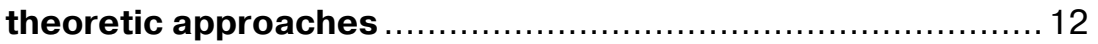

1.1. Market mechanisms for financial

regulation and their boundaries .................................... 13

1.2. The forms of bankruptcy: liquidation

or reorganization? ................................................... 20

1.3. Choices of bankruptcy procedures............................ 32

Chapter 2. Main legal phases in the development of the institution of insolvency in contemporary Russia

2.1. Traditional models and specific features

of the economy in transition

2.2. A general estimation of the provisions

of the 3rd Law on bankruptcy

2.3. The formation of a subordinate legal

base and regulation of the powers

of the bodies of state authority during

the period of the new Law being in force

2.4. Prospects for the modification

of bankruptcy legislation ........................................... 98

Chapter 3. Bankruptcy issues in regional legislations.......... 103

Chapter 4. The economic aspects

of the formation of the institution

of bankruptcy and the dynamics of cases

115

4.1. The specific economic

and institutional conditions for applying

bankruptcy procedures

4.2. The financial aspects of the activity

of large industrial enterprises in the context

of their potential insolvency.

4.3. The main trends in applying bankruptcy

procedures during 1998-2002 
4.4. The 3rd Law on bankruptcy: the first

results of its application in 2003 .

Chapter 5. The practice of applying bankruptcy

procedures for control takeover

and property redistribution

144

Chapter 6. The institution of bankruptcy

commissioners in contemporary Russia 168

6.1. Main Principles 168

6.2. Regulation of the activity of bankruptcy

commissioners: phases of development 171

Chapter 7. Canadian corporate bankruptcy: law and public policy 189

7.1. Background: economics of bankruptcy.................. 190

7.2. The Canadian system ....................................... 194

7.3. Legislative reform of the Canadian Acts ................... 204

7.4. The example of Air Canada ................................ 216

7.5. Matters of special interest in Russia....................... 237

Annex A: The ten acts of bankruptcy...................... 241

Annex B: Powers and liabilities of trustees under the BIA .................................. 242

Annex C: Statutory priorities in business insolvencies ............................................... 244

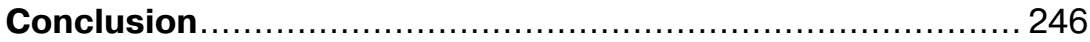

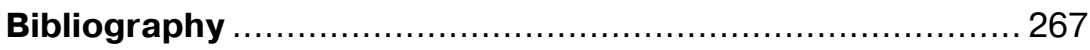




\section{Introduction}

Theoretically, the legal norms designed to regulate insolvency of enterprises may imply the achievement of the following goals: at the macrolevel - to decrease the levels of economic risks in the economy through liquidating inefficient enterprises, redistributing industrial assets in favor of efficient ones, and developing a competitive environment; at the microlevel - to protect creditors' rights, ensure financial discipline, improve the safety of credit circulation, reorganize enterprises, which includes financial restructuring; to improve the quality of corporate governance, redistribute property in favor of "efficient" owners, replace inadequately qualified managers, and implement rational management systems at enterprises.

At the same time, the effectuation of bankruptcy procedures always implies certain losses to creditors, debtors, and the State. Foreign countries with developed economies are no exception in this respect. The possibilities for applying bankruptcy procedures in order to reform businesses and to replace "inefficient" owners are quite limited, their basic goal being that of liquidating inefficient production, redistributing unreasonably utilized assets, and lowering economic risks in the economy; that is, bankruptcy procedures may serve a creative purpose primarily at the macrolevel.

The experience of foreign developed countries has not provided us with sufficient grounds for a firm belief that regulation of insolvency is to be effectuated only with the creditors' priority in mind; there do exist examples demonstrating that insolvency is primarily orientated toward protecting the interests of the debtor or the State. It all depends on the specific economic policy of a given state and is largely associated with the scope of its state-owned sector and the standpoints as to the necessity of its presence.

The role of bankruptcy as a means of exerting pressure on corporations' CEOs in a market economy is well-known and has been described in all of its aspects (both positive and negative) in the vast literature existing on this subject. The threat of a corporation's bankruptcy as a result of its CEOs' erroneous policy on the markets (and as the extreme variant - the taking of control by its creditors) is usually regarded as the most important external instrument of corporate governance. An 
obvious expected result of applying this mechanism (irrespective of the faults and merits of specific country-based models - be they procreditor or pro-debtor) must the rehabilitation of finances and improved efficiency of a corporation which has been subjected to such procedures.

At the same time, those specific objective limitations that characterize the situations existing in Russia and some other countries with transition economies and impede an efficient mass-scale application of this mechanism are also very well known:

- an unfavorable financial situation experienced by a considerable number of newly created corporations;

- the traditions of soft budget constraints;

- the preservation of a substantial number of corporations with the State's participation;

- the lack of an appropriate and highly qualified executive and judicial infrastructure;

- social and political barriers hampering the implementation of genuine bankruptcy procedures in respect to loss-making corporations, especially in the instances of very large enterprises or those forming company towns;

- numerous technical difficulties associated with objective estimation of the financial status of potential bankrupts;

- corruption and other criminal aspects of the problem, including those associated with property redistribution.

National legislation on bankruptcy is oriented towards a developed market economy, where the percentage of the economic subjects in respect to which it might be necessary to apply bankruptcy procedures is relatively small. However, the economic situation in Russia is fundamentally different. There exist, in fact, no doubts as to the necessity to create a well-developed institution of bankruptcy in Russia, and almost no doubts as to its positive influence already being felt in the sphere of small and medium-size business. The main object of criticism in Russia has now become the practice of bankruptcies of large enterprises.

Throughout the 1990s, the institution of bankruptcy in Russia was being applied either as a method for property redistribution (seizure, retention, privatization), or as a highly selective method of exerting political and economic pressure on enterprises by the State. A paradoxical 
situation could be thus observed: those enterprises that had a sufficient stability resource were being involved in bankruptcy procedures (due to the existence of a situation that favored the seizure of control over them by their competitors), while hopeless enterprises were avoiding this procedure (because there were no likely candidates willing to seize them, and the chances of recovering debts during the procedure of bankruptcy were slim).

While the institution of bankruptcy in the years 1992-1998 was more resembling an imitation of itself, the second law (adopted in 1998) distorted the situation still further, by making the institution of bankruptcy, instead of a method for ensuring financial discipline, an instrument for property redistribution and asset withdrawal. This had a direct bearing on tax payments. According to the Federal Service for Financial Rehabilitation and Bankruptcy ${ }^{1}$, every fifth bankruptcy had certain characteristics of premeditated criminal actions (in particular, bankruptcy as a way of writing-off debts). It should be admitted that the State, in its turn, also sometimes resorts to the threat of bankruptcy as an instrument of exerting pressure upon an enterprise in order to make it pay its tax debts, or for other purposes, including non-economic ones.

As a result, although the Russian Law "On insolvency (bankruptcy)", while being in force during 1998-2002, was formally quite progressive from the point of view of international practice, and implied that there existed a certain balance of debtors' and creditors' interests, the practical application of its norms became one of the most notorious examples of discrimination against some of the process' participants (the owners of an enterprise, or various creditors, including the State, depending on a specific situation).

Quite obviously, it was necessary, on the one hand, to ensure the protection of creditors' rights during the process of an enterprise's bankruptcy, and on the other, to protect the debtor from simplified procedures of a hostile takeover of control (or of a part of its assets) being applied to it within the framework of bankruptcy procedures.

\footnotetext{
${ }^{1}$ Since September 1993, there existed in Russia the Federal Administration for Insolvency (Bankruptcy) (FAIB) at the RF State Committee for State Property; in March 1997 the Federal Service for Insolvency and Financial Rehabilitation of Russia (FSIFR) was created, which in June 1999 was transformed into the Federal Service for Financial Rehabilitation and Bankruptcy of Russia (FSFRB). From March 2004, the FSFRB's functions have been distributed among several State bodies.
} 
Throughout the whole period of the 2nd Law on bankruptcy (now abolished) being in force, attempts were being made to somehow correct its provisions. During the discussion of the draft new (3rd) Law on bankruptcy, all the parties recognized the importance of finding solutions to the following problems pertaining to insolvency regulation:

- violation of the rights of the debtor enterprise and its owners, no possibilities for the latter to rehabilitate the enterprise under the creditors' control;

- insufficient protection of the rights of secured creditors;

- very limited rights of the State as the creditor in respect to mandatory payments, the need to further specify the procedures for the State's participation as a creditor in bankruptcy procedures;

- the problem of a conflict of interests among empowered State bodies, the legitimacy and consequences of the suggested extended powers;

- the widespread practice of applying bankruptcy procedures in order to seize (or intercept) the management of an enterprise and to withdraw the most attractive assets in the interests of some of the creditors;

- undeveloped mechanisms for enforcing the responsibility of bankruptcy commissioners;

- the need to specify the status of self-regulating organizations of bankruptcy commissioners, the terms of membership therein, and guarantee funds;

- the lack of reasonable special mechanisms for the effectuation of bankruptcy of enterprises belonging to the military-industrial complex and natural monopolies;

- the need to consider the feasibility of preventing the arbitrage court (which bears no responsibility) from making any decisions concerning the candidacy and qualifications of a bankruptcy commissioner, or decisions (or the approving of decisions) concerning an enterprise's assets;

- the need to discuss the issue concerning the elimination, in principle, of the procedures of "external administration" and "financial rehabilitation".

However, the existing notions as to possible solutions to the abovesaid problems in many cases frequently turned out to be directly con- 
tradicting one another. There existed no relatively uniform standpoint adopted by all State bodies concerning the possible transformation of insolvency regulation. It should be noted that in recent years the views of some of the State departments have undergone dramatic changes.

The intensity of the discussion on the new (third) Law on bankruptcy has increased, primarily, due to the drawbacks of this law (as well as any other law) within the general institutional context, which is characterized by problems associated with corruption, property redistribution, arbitrary approaches and incompetence of various State structures.

As a result, the new (third) Law "On insolvency (bankruptcy)" No. 127-FZ, adopted on 26 October 2002, contains the following fundamentally new provisions:

- greater protection of the rights and legitimate interests of creditors;

- an extended range of the right of honest owners (founders, participants) of a debtor enterprise, as well as stronger protection of their interests in bankruptcy procedures;

- the protection of honest participants in bankruptcy procedures from unfair actions of other persons;

- a change in the status of the bankruptcy commissioner;

- a change in the status of the State bodies participating in the procedure of bankruptcy;

- the introduction of a new procedure of bankruptcy to be applied to the debtor in order to restore solvency and redeem debts (financial rehabilitation).

The main goals of the present study are to analyze the formation of the institution of bankruptcy (insolvency) in Russia - in particular, to investigate the evolution of its legal base, the specific purposes of applying the institution of bankruptcy as a mechanism for property redistribution in Russia's economy in transition, and the motives and objects for applying these procedures; as well as to develop appropriate recommendations applicable to Russia's situation.

The study is designed as follows.

When analyzing the theoretic approaches to the problem of bankruptcy, the main focus of attention is the market mechanisms for financial regulation, the forms of bankruptcy (liquidation or reorganization) and the choice of bankruptcy procedures. 
The discussion of the general evolution of legal phases in the development of the institution of insolvency in modern Russia is preceded by a brief analysis of traditional models and the peculiar features of the economy in transition. In addition to an overall description of the first (1993-1997) and the second (1998-2002) phases, some specific issues are discussed - like, for example, the peculiarities of bankruptcies of certain groups of debtors, the basic insolvency procedures, etc. Nevertheless, in legal terms, the focus of attention is placed on the third phase (from 2002 onward), which implies an analysis and a general estimation of the main innovations introduced in the 3rd Law on Insolvency, a discussion of the issues pertaining to the formation of the subordinate base, the regulation of the powers of the State authority, and the prospects for the modification of legislation on bankruptcy. The analysis of the legal aspects is augmented by a discussion of the issues of bankruptcy in terms of regional legislations, as well as of a number of specific problems, e.g., that of the institution of bankruptcy commissioners, and some other issues.

The study on the economic aspects of the formation of the institution of bankruptcy involves a statistical analysis of the evolution of specific cases, as well as an investigation of the specific economic and institutional conditions for the application of bankruptcy procedures. This section addresses the main trends in the application of bankruptcy procedures during 1998-2002 and analyzes the preliminary results of applying new legislation in the year 2003.

When analyzing the economic aspects of the problem, special attention was paid to the practice of applying bankruptcy procedures for control seizure and property redistribution, as well as to the financial aspects of the activity of large industrial enterprises in the context of their potential insolvency.

Considerable attention in this study has also been given to the most important problems associated with law enforcement in the sphere of bankruptcy legistation. In particular, the following aspects of the lawenforcement practice have been investigated, which were of utmost importance in 2003-2004: the initiation of proceedings in the instance of insolvency (bankruptcy proceedings); a new procedure for appointing bankruptcy commissioners; the application of the norms concerning financial rehabilitation; the application of the norms concerning external 
administration; the application of the norms regulating bankruptcy proceeding and the procedure of amicable settlement; the application of the norms concerning bankruptcy in respect to an absent debtor; the bankruptcy of a debtor which is being liquidated; bringing to responsibility those violating the Law "On bankruptcy".

When analyzing the experience of corporate bankruptcies in Canada, the economic foundations of bankruptcy are discussed, and an overview is offered on the contemporary system of law and law enforcement in this sphere. Of especial interest, in terms of Russia's contemporary practice, is the study on the issues of reforming Canadian laws on bankruptcy. The case of "Air Canada" is discussed as an example of dealing with the most acute problems that may arise in bankriptcy.

The conclusion contains the principal deductions achieved during the study, as well as the main recommendations regarding further improvement of the institution of bankruptcy in Russia. 


\section{Chapter 1 . The problems of bankruptcy: theoretic approaches}

The determination of property rights in a situation where financial markets do exist cannot be regarded as complete, or even, quite simply, clear enough without finding solutions to problems associated with companies' insolvency ${ }^{2}$. To which degree the "automatic" functioning, as such, of the market mechanisms and/or the actions of the legal agencies undertaken in accordance with existing legislation are capable of protecting the interests of an owner of debt notes? And to what degree those bankruptcy procedures, which are being offered as "the optimal" ones, are capable not only of determining the range of an owner's rights, but also of ensuring a sufficiently active protection of his interests?

The economic and legal regulation of problems arising as a result of a company's insolvency belongs to the category of key issues pertaining to the functioning of private property and market relations; in particular, smooth functioning of the system of settlements and payments, as well as the intensity and profundity of the development of financial markets depend on the efficiency of such regulation. Nevertheless, so far the issues of bankruptcy, obviously, have not become fully reflected in standard neoclassical theory ${ }^{3}$. In day-to-day life and in the actual strategies of banks, corporations-borrowers and other participants in the economic process, the prospects of potential bankruptcy and its expected results usually are assigned a far more important role than in refined theoretic models of corporate behavior.

\footnotetext{
${ }^{2}$ Since only the most general aspects of the issue of bankruptcy are being dealt with here, while the "technical" (narrowly legal) details are left out, in the majority of cases (with the exception of some clearly specified points) no special distinctions are made between the notions of a company's "bankruptcy", "default", "inability to pay" or "insolvency".

${ }^{3} \mathrm{~J}$. Stiglitz in his Nobel Winner's Speech specially mentioned this circumstance. Stiglitz J. Information and the Change in the Paradigm in Economics. - "American Economic Review", 2002. Vol. 92, pp. 460-501.
} 


\subsection{Market mechanisms for financial regulation and their boundaries}

The analysis of the prospects for financing investment projects always takes into account the risk of bankruptcy ("credit risk"), and the interest rates being established on the market invariably include a risk premium. The amount of a credit risk premium depends on many factors: the borrower's credit history, the current and expected liquidity indices, the volatility of prices of the products manufactured by the borrower, etc. Thus, within the framework of certain boundaries, the market itself is redistributing incomes (or property) so as to answer the requirements established for private property functioning: all other terms being equal, the current value of a company on the verge of bankruptcy goes down, and accordingly increases the value of the creditor company.

Strictly speaking, the requirement that all the losses resulting from a failure to effect timely payments be redeemed can be envisaged in the terms of an appropriately drawn credit contract. However, the complexity of modern economic life and the impact of the factors of uncertainty and risk result in a situation when the formalization of a more or less complete contract might involve unreasonably high transaction costs ${ }^{4}$. It would be sufficient just to refer to the great variability of potential situations arising from insolvency, as well as to the possibility that, with time, the size and structure of a borrower's assets may undergo fundamental changes, whereas the terms for creditor compensation as stated in a contract will remain fixed.

An important role is also played by those information structures that determine the relationship in question. Given the existing uncertainty and information asymmetry, it is not easy to describe a situation when the problem of liquidity becomes acute and timely payments are impossible to effect by means of an ordinary determinist model of the market relations' functioning. In actuality, the relationships developing on fi-

\footnotetext{
${ }^{4}$ The concept of contract incompleteness put forth by $\mathrm{O}$. Hart and J. Moore, as well as the on-going theoretical debate concerning this issue, are discussed at greater length in the book: Radygin A., Entov R. (2001), Korporativnoe upravlenie i zashchita prav sobstvennosti: empiricheskii analiz i aktual'nye napravleniia reform (Corporate governance and protection of property rights: empirical analysis and vital areas of reforming). Moscow, 2001.
} 
nancial markets are characterized not only by uncertainty, but also by asymmetric information: as rule, a creditor has no direct access to the whole body of information available to the CEOs of a borrower company and is obliged to be oriented by current "signals". The main "signal", consolidated in a credit contract, becomes invariably the borrower's readiness to make the standard commitment to pay the debt and the interest thereof (as well as the consent to pay the established fines in the event of the said conditions being violated).

The equilibrium in a model that implies the use of such uniform signals and excludes any better differentiated information has been traditionally called "a pooling equilibrium". Economic theory states that in a situation of information asymmetry the participants (borrowers) would prefer to implement strategies implying that their signals will contain uniform (minimal) information. A pooling equilibrium is usually characteristic of a situation of a higher spending level (as compared to structures characterized by bilateral information flows), and the resulting economic efficiency, according to Pareto's criterion, will be lower ${ }^{5}$.

No less significant is the impact of externalities associated with the presence of several creditors and other participants in the economic process. This mutual dependency becomes especially obvious if one assumes for a moment that there exist no uniform bankruptcy procedures, and that the problems arising from the borrower's insolvency are to be solved only on the basis of the terms stipulated in an individual contract. How could then the impact of the said external effects reveal itself in the situation in question?

In such a situation, each creditor would conclude with the borrower an individual contract, stipulating therein appropriate specific terms for debt servicing. In the event of a violation of these terms, the creditor must be granted the right to enforce the recovery, for his benefit, of (a part of) the debtor's property. In reality, however, the range of liabilities of a borrower is almost never limited to money loans.

It will suffice to mention casual employees, who usually sign shortterm contract with their employer; such contracts, as a rule, do not envisage (at least explicitly) the company's possible insolvency. This consideration may also be true in respect to those contracts which a given

\footnotetext{
${ }^{5}$ See, e.g., Mas-Collel A., M. Whinston, J. Green. Microeconomic Theory. - Oxford University Press: New York, 1995, Chapter 13, Section C.
} 
borrower corporation has concluded with its other employees. Then, resulting from a violation of certain terms of the credit contract, the company's (entire) property will be utilized to cover its liabilities to a given creditor, while those to the employees (as well as to other participants in economic operations) will be left unpaid. Such situations represent an evidence as to how far from optimal (or simply unfair) may become the results of income and/or property redistribution in the event of a decentralized settlement of the financial problems of a borrower.

Similarly, complete fulfillment of a company's liabilities to one of its creditors may result in an impossibility to fulfill its liabilities to all the other creditors. In this connection, alongside the contracts between a borrower, on the one hand, and each of its creditors, on the other, contacts between creditors would also become necessary. The former group of contracts would then be determining the priorities of payments to different creditors, as well as the proportions of debt redemption in those instances when the mass of a bankrupt's estate is insufficient for the redemption of all liabilities.

It is clear that in a modern developed economy, numbering many thousands of stakeholders - creditors, employees, suppliers, etc., i.e., all those participants whose material interests are directly linked to the functioning of a given corporation, the formalization of such contacts would have required unimaginably high transaction costs. And the law on bankruptcy, which implies the existence of certain methods for uniform centralized settlement of financial problems arising as a result of a company's insolvency, can be regarded, according to one of the most eminent experts in the field of economics and law, simply as a standard contract, whose very existence would mean economizing on transaction costs ${ }^{6}$.

The existence of externalities in this sphere results in a search for appropriate terms to be stipulated in credit contracts that would ensure a relatively greater protection of property rights. For this purpose, in particular, mortgage notes have already been applied for a long time, when a loan is secured by certain real assets or securities. In the event of a violation of the credit contract, the creditor, in the majority of cases,

\footnotetext{
${ }^{6}$ Posner R. Economic Analysis of Law. 5-th ed. - A Wolters Kluwer Company, 1998, p. 442.
} 
could appropriate these assets in lieu of compensation (or the proceeds of their sale); in some countries, such claims to property have been put forth even irrespective of whether the registration of a bankruptcy procedure is effectuated.

Still, the development of the market for securities and bank credits can by no means be limited to mortgage notes. The role of "security" for liabilities being formed within various sectors of the financial market in the modern situation is being played primarily by a regular cash inflow to a company.

It is in the situation of a considerably worsened financial status of a given company that the priority for the fulfillment of obligations by a borrower is playing an especially significant role. This, as has been noted earlier, represents an important aspect of those externalities that influence the functioning of the credit relations which reveal the links existing between different markets.

When a company is making use of the services of only one creditor, has no obligations to any other stakeholders, and an appropriate credit contract provides a sufficiently clear statement of property rights ex post, an efficient solution, in fact, could be achieved through the "Coasean" processes (described by R. Coase ${ }^{7}$ ) of market bidding which utilize side payments. However, the uncertainty as to the subsequent distribution of property rights ${ }^{8}$, still further augmented by the presence of numerous creditors and other stakeholders, makes the overall picture look entirely different ${ }^{9}$.

The following circumstance is also worth considering. A creditor with certain claims presents these claims in respect to a part of property owned by the debtor, whereas the debtor company, even when capable of continuing its activity, can do so only if it utilizes all its assets (sup-

\footnotetext{
${ }^{7}$ See, e.g., Coase R. The Problem of Social Cost. - "Journal of Law and Economics", 1960. Vol. 1, pp. 1-44.

${ }^{8}$ Stressing this aspect of the problem is seen as especially important due to the enormous transaction costs required in such a situation.

${ }^{9}$ One, a simplest, example will suffice. Assume that a company's liquidation value amounts to 300 million roubles, while the amount of its liabilities to Creditor $X$ is 250 million roubles, that to Creditor $Y$ is 350 million roubles, etc. Then, by resorting to appropriate "compensational" incentives, Bank $X$ would be able to achieve an agreement with the debtor's CEOs concerning a complete repayment of its credits; the other creditors would then have to get reconciled to only a small proportion of the bankrupt's assets.
} 
posedly, the difficulties befallen to a company may represent an evidence that it has exhausted all its liquid, as well as all the other, reserves). And even if the company suspends its activity and makes an attempt to sell a part of its property in order to settle those liabilities in respect to which payments are due, this procedure of "partial" sale would result in a substantial reduction in its assets' total value.

Let us now discuss in more detail the relations developing between creditors, on the one hand, and the borrower company, on the other, during the period when the company begins to experience serious troubles. In a situation of growing financial tension and "setbacks" in fulfilling the terms of credit contracts, each creditor utilizes, when developing an appropriate strategy, the widest possible range of market "signals". When discussing the issue as to a possible interpretation of these signals in face of information asymmetry, P.Milgrom and J. Roberts convincingly demonstrated that given sufficiently plausible prerequisites, the only sequential equilibrium that can be possible within their model is based on an assumption that each of the decision-making participants is oriented to the most pessimistic interpretation of the signals being received. This principle is formulated as "assume the worst"

At a certain stage in the development of this process (when many creditors have the possibility to petition the court concerning a violation of a credit contract), the phenomenon of spontaneous realization of pessimistic prophecies inevitably occurs. In face of the expected attack, the most cautious (or active) creditors urgently present their claims to payment, and this, in its turn, induces other creditors to act, at the same time dramatically reducing the possibilities for refinancing the liabilities for which payments are due by means of new credits ${ }^{11}$.

The strategy of preemptive actions is an indispensable component of the zero-sum game. (From the point of view of efficiency in terms of

\footnotetext{
${ }^{10}$ See Milgrom P., J. Roberts. Relying on the Information of Interested Parties. - "Rand Journal of Economics", 1986. Vol. 17, pp. 18-32.

${ }^{11}$ In some theoretic papers, models of depositors' attack on a bank were built, describing in detail the logic of evolving "banking panic" and "mob behavior" in a situation of information asymmetry - see, e.g., Bryant J. Bank Collapse and Depression. - "The Journal of Money, Credit, and Banking”, 1981 Vol. 13, pp. 454-464; Diamond D., P. Dybwig Bank Runs, Deposit Insurance, and Liquidity. - "Journal of Political Economy", 1983 Vol. 91, pp. 401-419; Von Thadden "Optimal Liquidity Provision and Dynamic Incentive Compatibility". - 1995 .
} 
society as a whole, the game in question represents a negative-sum game, because the participants' strategies require substantial efforts and material resources). The competition in caution among the creditors, especially if one considers the random enough choice of "signals" and discrepancies in their interpretation, as well as the looming threat of attack on the company, must undermine any stability of production and financial operations being conducted by the borrower company.

In a situation of increasing financial troubles, the behavior of owners (holders of the main bulk of shares), as well as of the top managers of a borrower company would also display dramatic changes. The threat of a company's total collapse, coupled with limited liability of the shareholders in respect to its property, will promote a switchover to more risky operations.

This switchover is dictated by a certain logic. In face of a looming threat, entrepreneurs seemingly abandon their former caution and, in fact, attempt to utilize every opportunity for survival and recovery of income, including "too risky" ones ${ }^{12}$.

This trend is even more distinctly outlined in those actions of shareholders and CEOs that directly contradict the principles of efficient functioning of private property. Here we mean the strategy that involves the liquidation "from inside" of a company which is nearly bankrupt and a gradual withdrawal of a part of its assets from the company. The evolving operations are also characteristic of a negative-sum game: the resources and efforts of a company's owners and/or CEOs are spent on "recombining" - a redistribution of the actual ownership rights - thus resulting in destruction of the informational and organizational capital embodied in the economic structures that are being undermined.

Thus, the functioning of decentralized market mechanisms can ensure only a partial protection of the creditors' property rights. At the

\footnotetext{
${ }^{12}$ Since the 1970s, economic theory has been commonly applying option models of an insolvent company (among the most well-known publications in this field, a Nobel Prize winner's work can be mentioned - see Merton R. On the Pricing of Corporate Debt: The Risky Structure of Interest Rates. - "The Journal of Finance". 1974. Vol. 29, pp. 449-470. Within the framework of theoretic models like Merton's model, the transition to investment projects with a comparatively wide dispersion of expected incomes and losses can be easily explained by the growing value of the corresponding call option, which supposedly belongs to a company's owners (the price of the execution of such an option is equal to the nominal value of a company's debt liabilities).
} 
same time, while the structure of property relations is becoming more complex, the "explosive" trends also become more evident, of an opposite orientation.

As a company's financial status worsens, the scope of destructive processes also inevitably grows, which - in absence of efficient bankruptcy procedures - would logically follow the decentralized solutions to the problems resulting from insolvency. In such situations, the corresponding costs would also be increasing in leaps - the costs of insolvency resulting from the behaviors of both the creditors, who are trying to ensure the salvation of their loaned money, and the shareholders, as well as of the CEOs who are in charge of the borrower company. All this sets the boundaries for potential internalization of the abovesaid external effects, and more clearly reveals not only the functions of the centrally established bankruptcy procedures, but also the special ("priority") character of appropriate legislation.

The system of laws on bankruptcy establishes, in a mandatory procedure, unified criteria of a company's insolvency, regulates the procedure of registration in bankruptcy, as well as the procedures implying simultaneous consideration of all the liabilities of a debtor company to all interested parties. Thus, the existence of unified State standards, norms and procedures eliminates the possibility for constructing any special terms of settlement with one or other participant - the terms that could have been envisaged in individual contracts with regard to the event of a company's insolvency.

In this connection, the criteria of insolvency may originate not only from the fact of a failure to make payments against those liabilities whose time for redemption is approaching, but also from the overall indices of a company's financial status. Thus, in the USA, a company's "insolvency in a bankrupt sense" is determined on the basis of registered accounting records: the evidence of such insolvency can be provided, in accordance with the established definitions, by a negative net present value (in the document in question, the situation is being discussed when a company's liabilities are higher than its fair market 
value). Therefore, even companies that have never used loans may become insolvent in terms of bankruptcy ${ }^{13}$.

It should be noted that legislation on bankruptcy designed to overcome the limitations associated with the incompleteness of individual contracts, is also incomplete to a significant degree. An outcome of the proceedings in bankruptcy also largely depends upon the way the law's provisions can be interpreted in respect of a certain specific situation. Vivid evidence as to the incompleteness of the laws on bankruptcy can be provided by the huge amounts of money spent by interested parties on attracting "experts" - lawyers' companies specializing in bankruptcy proceedings, payment for the services of investment banks, etc.

Since bankruptcy norms and procedures must be uniform, the corresponding laws are usually adopted at the federal (national) level. However, the law-enforcement practice, as a rule, varies considerably depending on a particular region. The variable degree of creditor protection represents one of the factors that determine, in particular, the uneven distribution of non-payments and unequal development of credit and insurance operations in different administrative entities (states, republics, provinces, oblasts).

\subsection{The forms of bankruptcy: liquidation or reorganization?}

A theoretical analysis of the problem proceeds from the assumption that bankruptcy procedures must ensure the following:

- firstly, maximization of the current value of a company undergoing a liquidation or a reorganization procedure (efficiency conditions being realized ex post), and

- secondly, an optimal distribution (redistribution) of the said value among interested parties.

It is the latter condition, that is, the norms determining the proportions of income (or property) redistribution among interested parties, that influences the pre-bankruptcy actions of borrowers, creditors and

\footnotetext{
${ }^{13}$ Thus, a joint-stock company without any debts may find itself, in accordance with the abovesaid definition, "insolvent in terms of bankruptcy" in those instances, when, e.g., its average aggregate costs are higher than its average revenues (gross incomes).
} 
other participants in this relationship (stakeholders) (efficiency conditions being realized ex ante).

By setting certain standards in the sphere of property rights protection in the event of a company's insolvency, and thereby determining the "degree of reliability" of various liabilities, legislation on bankruptcy serves as a starting point for settlements effected between the participants in the economic process. Thus, specially determined terms and procedures of bankruptcy to a substantial degree influence the choice made by the owners (or CEOs) of a debtor company - either to sell the company, or to make a private agreement with creditors, or to officially declare the company bankrupt. The degree of protection of the owner's interests, as determined by bankruptcy procedures, is directly taken into consideration by creditors when estimating their investment risks.

As a company's financial troubles grow more serious, a dramatic confrontation is becoming obvious, which takes its root in a conflict of interests between its main participants - the owners of a borrower company, its CEOs, managers and creditors.

Joint-stock companies usually have an interest in bankruptcy being formalized after the moment of default on a flow basis, that is, after the period during which it is revealed that current revenues have become smaller than expenses. Shareholders count on the possibility ${ }^{14}$ that a rapid interruption of current operations can enable them to salvage a greater part of their own capital.

Creditors are rather more inclined to demand that bankruptcy procedures be effectuated at a later stage, when a default on a stock basis is revealed, which implies that current revenues become persistently (for a long time) smaller than required expenditures. In this instance, creditors may rely on exchanging at least a part of stale debt for shares in the company which has declared the default.

In the previous section, we already mentioned the limitations that may appear when the solutions to problems resulting from a company's insolvency are being sought by resorting to decentralized (purely "market") measures. However, the establishment of centralized bankruptcy procedures (involving all interested parties) does not (nor can it) exclude the application of market methods of financial regulation; such

${ }^{14}$ See Wruck K. Financial Distress, Reorganization, and Organizational Efficiency. "Journal of Financial Economics", 1990, Vol. 27, pp. 419-444. 
procedures may be regarded, rather, as representing only one of the components of the infrastructure serving as a framework for market processes. In this connection, we should like to refer to one of the manifestations of these connections. Before appealing to court with a petition in bankruptcy, each party invariably tests the situation by making an attempt to seek more beneficial terms through private agreements with its partners.

The negotiations initiated shortly after a default on a flow basis is revealed are usually more productive (and more often result in compromise settlements), the narrower is the circle of "strategic" creditors". Experience has shown that many conflicts can be resolved during such negotiations ${ }^{16}$. If the participants are still unable to come to an agreement, then bankruptcy procedures as regulated by the law are initiated.

Behind the confrontation of the interests of various participants, there is actually an objective conflict - that of the functions which are to be realized during the process of bankruptcy. Such procedures have as their primary objective the compliance with the rules dictated by the existence of property rights. In the event of a company's persistent insolvency, this implies the sale of a debtor's property on the most beneficial terms (the first of the conditions listed in the first paragraph of this section) and the fulfillment of this company's obligations to all interested parties to a maximum degree.

For another thing, a company's liquidation, with sale of all its property, is not always justified from the point of view of the economy's functioning as a whole. Moreover, such actions are not always justified even on the basis of the abovementioned efficiency conditions being realized ex post: support to and reorganization of a "viable" company may result in a growth of its NPV (net present value). A company's liqui-

\footnotetext{
${ }^{15}$ See, e.g., Gilson S., K. John, L. Lang Troubled Debt Restructurings: an Empirical Study of Private Reorganization of Firms in Default. - "Journal of Financial Economics", 1990. Vol. 27, pp. 315-354.

${ }^{16}$ The above-mentioned paper by S. Gilson, K. John and L. Lang gives the results of a study of 387 corporations whose shares were circulating on the New York and American Stock Exchanges (1978-1987) and were listed as the lowest 5\% of shares (the least "successful", according to the exchanges' criteria). Up to one-half (or, more exactly, $47 \%$ ) of those companies that had faced serious financial problems and were, at least temporarily, insolvent, were able to achieve an agreement concerning the restructuring of their debts in the course of private negotiations with their creditors. Thus, only about onehalf of the insolvent companies had to directly undergo bankruptcy procedures.
} 
dation must serve, in fact, as the evidence of it having exhausted all its potential for utilizing the assets in question within the framework of established property structures; it is often followed, as mentioned earlier, by an irreversible destruction of all accumulated informational and organizational capital.

Earlier it has been noted that by far not every inefficient ("nonviable") company undergoes official bankruptcy procedures. The other side of this equation should be noted, too: by far not every company that has been officially declared bankrupt is truly "non-viable". In actual practice, the situations when a company's insolvency arises due to a temporarily unfavorable economic situation, e.g., a minor error in managing cash funds, various transient "shocks", etc., are rather common. Liquidity problems, commonly associated with fluctuations on the financial markets, especially often serve as direct causes of default.

In this connection, however, the following circumstance should also be taken into consideration. Suppose that a given industrial company may be utilizing state-of-the-art technologies and sufficiently good equipment, and at the same time find itself in a troublesome financial situation due to transient market "shocks" or inadequate quality of management. Then the most probable method of reorganizing this company in the contemporary situation would be its takeover (with a possible subsequent replacement of the CEOs). However, if potential investors display no active interest in a company (while the lack of market demand is not associated with any specific circumstances, like too large a size of a company), this may be interpreted as an indirect evidence of the prospects for the reorganization of this company being rather dubious, or fraught with too many risks ${ }^{17}$.

\footnotetext{
${ }^{17}$ As to the percentages of "culling" of private corporations through different channels, the results of the study by Ogden J., F. Jen and P. O'Connor can be cited. These authors demonstrated that among approximately 5,000 American non-financial corporations, whose shares were in public circulation at the end of the year 1995, by the end of 2000 one-fifth had been out of operation (22\%). More than three-quarters of all "vanished" companies (848) had been taken over. And less than one-tenth of the vanished companies (amounting to only $2 \%$ of the total number of corporations studied) chose to be officially declared bankrupt (see Ogden J., F. Jen, P. O'Connor "Advanced Corporate Finance: Politics and Strategies" Prentice Hall: Upper Saddle River, N.J. 2003, pp. 626627). Thus, the majority of the vanishing companies are being directly "sorted out" by the market's special sector - the market for corporate control.
} 
P. Bolton and D. Scharfstein, in their theoretical model ${ }^{18}$, differentiate between liquidity default, when cash inflow during a certain (not too long) period of time proves insufficient, and a strategic default, when a company's revealed insolvency has originated from its CEOs' strategy aimed at buying-out the company after it becomes clear of debt. From the point of view of efficient management, as follows from the authors' argumentation, it is by far not always reasonable to undertake a company's liquidation shortly after its default (especially liquidity default). If the participants - CEOs and creditors - conclude contracts on optimal terms, strategic default may no longer be attractive in the eyes of the CEOs.

In reality, however, it is not easy to find any distinct criteria that might help to subdivide private companies undergoing a period of financial trouble into "viable" (in terms of economics) and "non-viable". Balance sheets as such contain little information for making adequate judgments as to the degree of efficiency of one or other method for an alternative utilization of real assets. Difficulties of this sort have often been mentioned in literature on economics: by a number of the most common accounting indices, the companies on the verge of bankruptcy (or those that have directly revealed their inability to make payments against current liabilities) may closely resemble those operating in the most dynamic sectors of the economy ${ }^{19}$, and this resemblance can hardly be regarded as simply accidental.

As an example of the conditions influencing the choice between a company's liquidation and reorganization, the contemporary US prac-

\footnotetext{
${ }^{18}$ Bolton P., D. Scharfstein Optimal Debt Structure and the Number of Creditors. - "The Journal of Political Economy", 1996. Vol. 104, pp. 1-25.

${ }^{19}$ Thus, P. Booth and B. Hutchison made an interesting comparison between basic economic indices of 33 Australian companies that have been registered as insolvent, and 33 new Australian corporations whose shares have for the first time entered public circulation. The authors could not distinguish any considerable statistical differences between these two groups. Both were demonstrating not only lower profitability indices (as compared to the economy's averages), but also comparatively lower liquidity. Moreover, in both groups the specific weight of borrowed funds in total liabilities (the size of the "financial lever") was found to be considerably greater than the average indices computed for all companies - see Booth P., P. Hutchison Distinguishing Between Failing and Growing Firms: a Note on the Use of Decomposition Measure Analysis. - "The Journal of Business Finance and Accounting". 1989, pp. 267-271).
} 
tice may be reviewed (the peculiarities of legislations on bankruptcy existing in other countries will be dealt with later).

In accordance with Article 11 of the 1978 Law, the filing of a petition in bankruptcy by a borrower company may automatically grant it a certain "pause": in those instances when a company continues to function and its market value remains above zero, creditors (including the owners of mortgages notes) for a certain time cannot set up their claims to the property owned by that company.

Article 11 of the Law "On Bankruptcy" grants to managers an exclusive right to develop, during the first 120 days after bankruptcy registration, their plans for reorganizing a bankrupt company (in some instances this period may be extended by a court decision). At the same time, within 180 days the reorganization plan's developers must obtain the creditors' approval of their variants of reorganization. If the CEOs have failed to produce such a plan (or it is not supported by the creditors), the latter may offer their own plan of the company's reorganization $^{20}$. In a vast majority of cases such a project is presented by the CEOs' of a company experiencing a critical situation ${ }^{21}$.

As a rule, the discussion of the plans for a company's reorganization and the subsequent court decision lasts for no longer than one or one and a half years. The period of reorganization is usually lengthier, especially in the economy's more capital-intensive sectors. Thus, the average reorganization period of bankrupt railway companies in the USA in the last century exceeded 13 years ${ }^{22}$.

Modern analysis of the interactions between the main participants in bankruptcy procedures - the creditors and CEOs of a borrower company - often makes use of game models, and particularly of the wellknown bargaining model offered by A. Rubinstein ${ }^{23}$.

\footnotetext{
${ }^{20}$ Reorganization plans suggested by banks are usually less trusted by participants, and sometimes by the judicial authorities as well. Therefore, in the majority of cases such plans are submitted for several experts' estimations, and are reviewed far more thoroughly and carefully.

${ }^{21}$ Weiss L. Bankruptcy Resolution: Direct Costs and Violation of Priority of Claims. "Journal of Financial Economics", 1990. Vol. 27, pp. 285-314.

${ }^{22}$ Warner J. Bankruptcy Costs: Some Empirical Evidence. - "The Journal of Finance", 1977. Vol. 32.

${ }^{23}$ Rubinstein A. Perfect Equilibrium in a Bargaining Model. - "Econometrica", 1982. Vol. 50, pp. $97-110$.
} 
In accordance with this model's general logic, let us assume that two persons participate in bargaining - a borrower company's CEO (hereinafter - the Manager), and a representative of united creditors (hereinafter - the Creditor). In this conflict, each party has access to certain means of exerting pressure on its partner in the negotiations.

The Manager can, as noted earlier, suggest a plan for the company's reorganization. However, in accordance with US legislation, the Creditor may veto the implementation of this plan, if therein it is envisaged that the creditors' claims to property be secured by amounts that are not even as high as the company's liquidation value.

On the other hand, the Manager may make the Creditor face a situation when the former quits his post for another job with a higher income. Consequently, the Manager's share in the incomes of the company being reorganized in accordance with his plan is expected to be no less than the salary he can hope to receive at another company. The less the losses caused by the Manager's quitting his position and the subsequent devaluation of the specific investments of human capital, the stronger the Manager's position in the conflict with the Creditor will be, all other positions being equal.

The US practice of choosing between liquidation and reorganization may be an evidence of the fact that the CEOs and owners of a borrower company in many cases succeeded in implementing a plan that enabled creditors to trade their debt notes (bonds) for shares in a new company in an amount that was only slightly greater than the old company's liquidation value. In accordance with such an agreement, a company's former obligations are redeemed by its shares (if it continues to exist) or the shares in a newly organized corporation. Having achieved an agreement with its creditors as to property rights redistribution and the court's approval, the company may continue to operate $^{24}$.

Moreover, by applying, with the purpose of exerting pressure on the Creditor, those reorganization projects that must result in a substantial

\footnotetext{
${ }^{24}$ Thus, in 2003 the largest ever bankrupt in the USA's history - the company "World Com" succeeded in achieving an agreement with its creditors as to restructuring its liabilities. By transferring a past of its assets and providing shares in exchange for its debt liabilities, the company managed to reduce its debt from 30 billion USD to 3.5-4.5 billion USD. By the year's end, the court is to bring its verdict concerning the achieved agreement.
} 
reduction in a company's liquidation value, the Manager sometimes have succeeded in getting the Creditor to make even more important concessions (which corresponds, naturally, to the interests not only of the CEOs, but also the owners of the old company). In those instances when the potential losses associated with the CEOs' plan of trading debt liabilities for shares seem not to be "too great", as noted by Y. Bergman and J. Callen, the threat appears to be effective, and the creditors agree to give in to reasonable demands. They believe that in many cases it is this "trading" that provides the foundation for negotiating as to the destiny of existing debts between the company's owners and creditors ${ }^{25}$.

The arsenal of effective threats applied by the Manager includes, as noted earlier, certain ultimatum-like proposals to the effect that if the Creditor rejects the plan, its author will simply quit the company. Can the Manager, through blackmailing the Creditor with such prospects, negotiate an even greater share for himself in the reorganized company and force the Creditor to be content with the amounts of money that would not even be equal to the old company's liquidation value? And if such a possibility does exist, can the scope of the entailing concessions be clearly determined? The authors of a monograph, specifically discussing the application of game models in studying the conflicts arising in the sphere of economic law, comment rather skeptically that there obviously exist no clear answer to either of these questions ${ }^{26}$.

It has been already mentioned earlier that one of the conditions for a company's reorganization is the restructuring of debt liabilities and/or changing of property structure: the creditors thus become co-owners of the new corporation. In this connection, considerable difficulties are given rise to by externalities and the problems associated with coordinating the interests of different creditors. Consider, e.g., those cases when a part of debt is represented by corporate bonds circulating on the securities market. As has been shown by the practice of bankruptcies of large US companies, the banks that have granted loans to a bankrupt company usually agree to more beneficial (for that company)

\footnotetext{
${ }^{25}$ Bergman Y., J. Callen Opportunistic Behavior in Debt Renegotiations and an Interior. 1991, p. 138.

${ }^{26}$ Baird D., R. Gertner, R. Picker "Game Theory and the Law". - Harvard University Press: Cambridge, Mass, 1998, p. 235.
} 
financial terms of reorganization only when it becomes clear that the trust companies or banks representing the interests of their bonds' owners are also ready to make appropriate concessions.

An acute conflict of interests, naturally, arises between the owners of secured and non-secured liabilities. When trading for shares in the new companies, the owners of mortgage notes are trying to negotiate the amounts of money that would be at least no less than the value of mortgage securities. At the same time, growing risks and uncertainties during reorganization in some instances induce the owners of bale bonds to oppose the majority of other participants and to prefer the liquidation of the bankrupt company ${ }^{27}$. Also, after reorganization has been completed, the privileged position of mortgage notes is gradually "being eroded": in order to provide financing for the newly created company, the highest status, under the existing laws, is granted to the claims of those creditors who are ready to offer new loans to the company in question.

Assume, however, that the conflicting parties - say, the Manager and the Creditor - have failed to come to an agreement. It is only in this case that the judicial agencies in charge of bankruptcy proceedings must make the decision as to the company's destiny and the entailing procedures of its liquidation or preservation. In the event of reorganization they not only determine the "genuine value" of a new corporation, but also make the decision as to how the securities to be issued by that company against a particular amount of money are going to be distributed among all the interested parties.

It is not difficult to notice that the bankruptcy system described here can ensure sufficiently favorable conditions for reorganizing bankrupt

\footnotetext{
${ }^{27}$ Suppose, e.g., that in one year the value of the reorganized company, with probability of $4 / 5$, may amount to 150 (money units), and with probability of $1 / 5$ - 900 (the mathematic expectation of the company's value will accordingly amount to 300 ), whereas this company's today's liquidation value is 190, while the claims of mortgage owners amount to 200. Assume that these participants' attitude to risk is neutral; discounting, for simplicity's sake, is disregarded. Then the majority of the participants will be for the company's reorganization $(300>190)$, whereas mortgage owners will be against it - because their expected income $(150 \cdot 4 / 5+200 \cdot 1 / 5=160)$ will be less than the income which they would have received in the event of the company's immediate liquidation (190). Discussing bankruptcy of Macy, a large US trade company, $\mathrm{O}$. Hart notes the influence of the liquidation strategy supported by mortgage owners (see Hart O. "Firms, Contracts and Financial Structure". - Clarendon Press: Oxford, 1995 p. 166).
} 
companies. By contrast, the US procedures may be compared to the British bankruptcy practices. In the UK, the Manager of a debtor company has no right, without the Creditor's consent, to file a petition in bankruptcy, and bankruptcy procedures as such are never implemented through enforcement. (A somewhat similar situation can be seen in Canada, where the Creditor, after several months have passed since the formalization of a petition in bankruptcy, is granted the right to appropriate the debtor's property ${ }^{28}$ ).

Among factors determining the specific features of the British bankruptcy system, we are going to stress only the following circumstance. In the UK, the prevailing majority of companies are serviced by only one creditor (floating charge creditor). Until a non-financial company makes the decision as to placing its bonds with a comparatively wider circle of investors, the problems caused by externalities are not felt too acutely.

This system, in its essence, is close to the credit contract privately concluded between a borrower and a creditor, described in the previous section. In accordance with the standard credit contract, in the event of a borrower company's insolvency, its "strategic" creditor may have justified claims to its incomes secured by sale of (part) of its property, primarily liquid financial assets and inventory holdings.

When applying A. Rubinstein's game bargaining model, it can be argued that in the UK and Canada the Creditor enjoys far greater exit options. Because of this, the equilibrium determining the distribution of funds resulting from a company's liquidation, or the securities issued by a new company as a result of reorganization, can be substantially tipped in favor of the Creditor.

In order to make more explicit the special role being played, during such bargaining, by the ratio between the current market value of a company continuing its activity (estimated value of the plans being offered) and the liquidation value of an old company, let us return to US bankruptcy legislation. In the USA, the Creditor's exit options are represented, as noted earlier, mainly by his rights to the bankrupt company's liquidation value.

Suppose that a company is continuing its economic operations, and it becomes known that its current market value is not higher than the liquidation value (an explicit evidence of the market's pessimistic atti-

\footnotetext{
${ }^{28}$ The procedure of bankruptcy in Canada is discussed in a special section.
} 
tude to the prospects of an alternative utilizations of the assets owned by the company in question). In this case, the Creditor, in accordance with established bankruptcy procedures, may reject the provision concerning an automatic suspension of all claims and immediately put forth his claims to the bankrupt company's property.

However, it follows that the choice between a bankrupt company's liquidation or reorganization by no means can always ensure an efficient solution: it may be made in favor of reorganization exactly at the moment when the prospects for such a "reorganization" are rather far from beneficial. It is true that the decision concerning a company's reorganization may simply result from the fact that this company's very outdated (or highly specialized) equipment cannot find any potential buyers on the market, and thus its market value becomes low. The low liquidation value of property (serving as the grounds for the court's decision to reorganize the company) as such may be an evidence an unfavorable estimation, on the part of the majority of the participants in the economic process, of the prospects for this property's alternative utilization (in our example, the obsolete industrial equipment).

Nevertheless, despite all the reservations, bankruptcy procedures are often constructed so as to ensure an adequate comparison between the potential benefits offered by a bankrupt company's reorganization and those incomes that may be generated by the sale of its property on the market. This comparison, in particular, constitutes "the core" of US bankruptcy legislation. According to a number of experts (R. Pozner, M. White), in the USA and France bankruptcy procedures are somewhat "biased" toward preservation and/or subsequent reorganization of companies experiencing financial troubles ${ }^{29}$. In the UK, as noted earlier, these procedures have a certain "bias" in the opposite direction.

Reorganization and liquidation of an insolvent company often represent two alternative opportunities in bankruptcy. However, in actual practice this opposition may become only temporary. The US experi-

\footnotetext{
${ }^{29}$ Earlier, we cited the results of a survey of approximately 5,000 US corporations, whose shares were being publicly circulated (Ogden J., F. Jen, P. O'Connor "Advanced Corporate Finance: Politics and Strategies" Prentice Hall: Upper Saddle River, N.J., 2003, pp. 626-627). Among the 107 companies declared bankrupt in 1996-2000, 95 were maintained and reorganized, while only 12 companies were liquidated, that is, no more than $1 \%$ of the total number of the companies which "had expired" since the end of 1995.
} 
ence has shown that quite a few plans end up in the liquidation of a "reorganized" company, or in the necessity of a new reorganization (restructuring of financial liabilities) $)^{30}$.

The frequent failures of reorganization may be explained by several factors, some of which have been mentioned earlier in this paper. Therefore we are going to make here only a reference to the very imperfect information that is often taken as the foundation for the plans of restructuring the economic operations aimed at "extending the life" of a bankrupt company. M. White, Professor at the University of Michigan, points out the following specific features of "pooling equilibrium" in signal models describing the situation of bankruptcy and applied to them the term "filtering failure" (failure to achieve "filtering")

Thus, the CEOs of "non-viable" companies (e.g., companies utilizing outdated technologies and worn-out equipment) strive to prove that the costs of the company's reorganization would not be too high. In face of the still asymmetrical information flows, the determination of the true scope of these costs turns out to be quite an expensive affair (substantial expenditures are needed, in the first place, simply for estimating the real amount of expected costs). Besides, the CEOs' opponents - the creditors - are by no means interested in a noticeable "fall" in the market value of the property which is subject to conflicting claims.

Quite often a company encounters financial difficulties due to the fact that its products have become outdated and are less in demand (an evidence of the transition to the final phases in the product's life cycle). Then, even after a "cosmetic" reorganization, as well as the restructuring of financial liabilities, haven taken place, the market price may still be lower than aggregate costs. This situation has been describes in detail in economic theory. The "reorganized" company will, for a certain period of time, continue its activity in instances when its price is higher than variable costs; the period of the company's unprofitable functioning is determined by the amount of its accumulated liabilities, as well as by other factors.

\footnotetext{
${ }^{30}$ Hotchkiss E. Postbankruptcy Performance and Management Turnover. - "The Journal of Finance", 1995. Vol. 50, pp. 3-21.

${ }^{31}$ White M. Corporate Bankruptcy as a Filtering Device: Chapter 11 Reorganizations and Out-of-Court Debt Restructurings. - "Journal of Law, Economics, and Organization", 1994. Vol. 10, pp. 268-295.
} 


\subsection{Choices of bankruptcy procedures}

Bankruptcy legislation, as it currently exists in the developed market economies, has been subject to intense criticism. Some of its limitations are clearly exemplified by the USA's bankruptcy procedures discussed in the previous section. The choice between a company's liquidation and reorganization depends on each of the participants' actions, aimed at increasing their incomes (or reducing the revealed losses). Given the contemporary bankruptcy practices in the majority of countries, the strong market positions of one of the parties involved, its selfish interests and manipulations may result in an inefficient decision as to the future destiny of a bankrupt company. The role of these circumstances is especially important in situations when it becomes possible to exert political pressure and engage the judicial agencies for a personal benefit, while the judges and bankruptcy commissioners are corrupt.

According to the principles of microeconomic analysis, the decisions concerning the future destiny of a bankrupt company must, to the greatest possible degree, be separated from those concerning the distribution of incomes (or property) among interested parties. So far, a number of sound considerations have been offered concerning optimal bankruptcy procedures and possible areas for the practical implementation of appropriate reforms.

The majority of economists and lawyers agree that the bargaining, which in fact goes on directly between all the participants in bankruptcy, must be limited in favor of open auctioning procedures (see Section 1). L. Bebchuk ${ }^{32}$, followed by P. Aghion, O. Hart and J. Moore (hereinafter referred to as $A H M)^{33}$, offered the following solution to this problem: bankruptcy procedures must lead to the creation of a new corporation, wherein all interested parties may become shareholders. Such a company is much less in debt; the stale debts of the bankrupt company (fully, or at least in part) are traded for shares in the new corporation.

Among the decisions to be taken by shareholders, the following two, in AHM's opinion, should be specifically mentioned: 1) whether the

\footnotetext{
${ }^{32}$ Bebchuk L. A New Approach to Corporate Reorganizations. - "Harvard Law Review", 1988 . Vol. 101, pp. 775-804.

${ }^{33}$ Aghion P., O. Hart, J. Moore Insolvency Reform in the UK: A Revised Proposal. - "Insolvency Law and Practice", 1995 Vol. 11, pp. 67-74.
} 
company should be reorganized or liquidated, and 2) what should be the percentages for exchanging the former debts for shares. In accordance with the procedures suggested by these authors, the issue of making a choice between maintaining or liquidating a company becomes to a much greater degree separated from that of income and property redistribution.

The issue concerning the future destiny of a bankrupt company, according to AHM's initial plan, must be resolved through open auctioning $^{34}$. The proposals put forth during such auctioning may include not only considerations concerning the company's reorganization, but also the terms for buying it out, which have been submitted for the consideration by a shareholder meeting. Thus, the CEOs of another company may offer a certain price for the bankrupt company, using as a means of payment (as it often happens in reality) shares in the company for which these CEOs are working. Such a proposal under certain conditions may imply, in fact, a takeover of the insolvent company effectuated within the framework of bankruptcy procedures.

Free bidding at an auction must ensure a free choice among the widest range of possible variants envisaging different ways for utilizing the assets owned by the bankrupt company. An overall supervision over the auctioning is effected by an arbitrage court, while the decision concerning the submitted proposals (including the proposals to liquidate the company and to purchase its property) is to be made by a shareholder meeting and to be submitted for the approval of appropriate judicial agencies.

The submitted projects are also aimed at limiting distortions caused by the asymmetry of the informational structures. The judicial agencies responsible for supervision must carefully see to it that each of an auction's participants (or potential shareholders) have free access to all the data contained in the company's accounting reports.

In accordance with the scheme suggested by L. Bebchuk, conflicts between the owners of mortgage notes and other creditors may be settled in the following way: the owners of preferred debt notes receive (in

\footnotetext{
${ }^{34}$ As D. Baird has shown, the more developed the capital markets, the stronger is the inclination of the bankruptcy procedure toward auction bidding (Baird D. The Uneasy Case for Corporate Reorganizations. - "The Journal of Legal Studies", 1986. Vol. 15, pp. 127-147.
} 
accordance with the amount of a specific debt) shares in a newly organized company, whereas all the other creditors, in exchange for their debt notes, are to be given options for purchasing shares in the new company. In the event when the value of a bankrupt company exceeds the amount of money needed for satisfying claims of all the creditors registered in a settlement in bankruptcy (or determined by a court decision), the owners (or shareholders) of the bankrupt company, posterior to the least preferred creditors, also receive options. As for the cost of option implementation, it may be different for each of the specified groups of participants. Before voting, the owners of options make a decision as to which possibilities, out of those granted by their options, they are willing to implement, and, accordingly, which portion of shares they are going to buy out from the owners of preferred debt notes ${ }^{35}$.

When setting the prospects for reforming UK bankruptcy legislation, AHM have somewhat modified this scheme ${ }^{36}$.

The first step in implementing these procedures could become the replacement of a bankrupt company's CEOs by an independent expert experienced in dealing with issues of bankruptcy - a "bankruptcy practitioner" ${ }^{37}$. It is this expert and his office who put forth the company's reorganization plan (or its sale as a going concern, or termination of its business operations and liquidation of its property). The practitioner may, of course, abstain from offering any rigid recommendations and simply present a document estimating the faults and merits of each available variant. As in the latter case, the ultimate decision is to be made by a shareholder meeting, and then be submitted for the approval of the judicial agencies.

When making a general review and critical estimation of the previously applied bankruptcy schemes, O. Hart, R. La Porta, F. Lopez-deSilanes and J. Moore in 1997 suggested a new plan. The shares that used to be part of the former procedures were now given a new name -

\footnotetext{
${ }^{35}$ Bebchuk L. "Using Options to Divide Value in Corporate Bankruptcy". NBER Working Paper №7614, Cambridge, Mass, 2000.

${ }^{36}$ Aghion P., O. Hart, J. Moore Insolvency Reform in the UK: A Revised Proposal. - "Insolvency Law and Practice", 1995. Vol. 11, pp. 67-74.

${ }^{37}$ Under UK conditions, the functions of such an expert could be performed, according the authors, by one of investment or commercial banks, while in Germany or Japan - by the "head bank" of a financial-industrial group.
} 
"reorganization rights". The distribution of these rights is to be effected through auction bidding.

At an "internal" auction, these rights may be purchased by a bankrupt company's creditors, while the terms of such purchase, naturally, depend on the "degree of preference" of each of the claims. An "external" auction is a public one, where any person, and primarily investors convinced in the need for the company's reorganization, may purchase these rights from the bankrupt's creditors. And finally, one more auction takes place, during which the decision as to the future destiny of the bankrupt company is made - whether it is to be liquidated or maintained - is held by a meeting of the owners of the reorganization rights $^{38}$.

In the above-mentioned (as well as in some other) plans, one common feature can be discerned: their authors are always eager to place bankruptcy procedures in the mainstream of ordinary corporate governance patterns, given that after the implementation of options and final distribution of shares, a newly formed corporation will strongly resemble an ordinary joint-stock company, which will have to make decisions concerning possible ways for overcoming its financial difficulties (it should also be noted that in contrast to the former (bankrupt) company the new one will be free from debts that are too heavy to shoulder).

In accordance with this bankruptcy procedure, a participant (or group of participants) interested in reorganization will have to spend certain funds in order to purchase - at a more or less preferential price the amount of shares, or "reorganization rights", that would enable them to ensure the passing of a certain decision at a shareholder meeting. This must induce investors to examine the real prospects for the planned reorganization with especial care. Among the drawbacks of such a scheme, one may point out the privileges (which are not necessarily justified) granted in this instance to the owners of "the most preferred" obligations: these owners will be able to appropriate, without any risk, a substantial portion of the incomes resulting from the company's reorganization.

\footnotetext{
${ }^{38}$ In more detail this plan is described in: Hart O., R. La Porta Drago, F. Lopez-de-Silanes, J. Moore A New Bankruptcy Procedure That Uses Multiple Auctions. - "European Economic Review", 1997. Vol. 41, pp. 461-473.
} 
The option-based methods of settlement, suggested by Professor of Harvard University L. Bebchuk, and openness of information make these procedures more flexible. The interested parties thus get an opportunity for a certain (naturally, not very long) period of time to review the available economic data and, after evaluating the prospects for reorganization, make more efficient market-based decisions.

The general orientation of the above-mentioned reforms can hardly be met with any serious objections. The suggested changes in bankruptcy procedures may contribute to a more sound settlement of the central issue - that of a choice between a bankrupt company's liquidation or reorganization. A more clear and consistent implementation of the principle of auction bidding, both at the stage of forming the core owners of "reorganization rights" and at the stage of collecting proposals as to the company's destiny, could, without any doubt, improve the efficiency of bankruptcy procedures.

However, the implementation of these proposals, even in developed market economies, usually encounters resistance on the part of those creditors and CEOs who can benefit greatly from the existing system of bankruptcy. At the same time, the implementation of such reforms is fraught with some practical difficulties (the need to change bankruptcy's legislative base, the shortage of highly qualified independent experts who are playing a central role in all abovementioned plans, the inevitably high expenditures involved in the organization of proposed auctions, etc.).

Lately, there have appeared quite a few theoretic studies on the development of optimal bankruptcy procedures ${ }^{39}$. In some of them, a comparatively more flexible approach can be detected: for different economic systems, similarly different optimal bankruptcy rules are of-

\footnotetext{
${ }^{39}$ See, e.g., Povel P. "Optimal "Soft" and "Tough" Bankruptcy Procedures" Financial Markets Group. Discussion Paper No. 240, London School of Economics: London, 1996; Berkovich E., R. Israel, J. Zender Optimal Bankruptcy Law and Firm Specific Investments. "European Economic Review", 1997. Vol. 41, pp. 487-497; Berkovich E., R. Israel, J. Zender The Design of Bankruptcy Law: a Case for Management Bias in Bankruptcy Reorganizations. - "Journal of Financial and Quantitative Analysis", 1998. Vol. 33, pp. 441464.
} 
fered. Below we are going to discuss in somewhat more detail one of such models ${ }^{40}$.

The central role in this model is played by the quality of the borrower company's management (which reveals itself, in particular, in the degree of efficiency of the investment project chosen by a CEO) and the asymmetrical structure of information flows. The main actors, as before, are the Creditor and the Manager.

In the theoretic model discussed by the authors, the group of variables that influence cash inflow to the company contains $\mathrm{M}$, which characterizes the project's "quality" at moment $t=1$. By that time, the credit contract has already been signed (it is signed at moment $t=0$ ). The Manager succeeds in obtaining timely information (at $t=1$ ) concerning the value of $M$. At moment $t=1$ the Creditor, who does not possess direct information as to the value of $\mathrm{M}$, makes a decision, in accordance with which he may expect debt settlement at moment $t=2$ or initiate proceedings in bankruptcy against the borrower.

This signal model is reflexive: an important role is played therein not only by the question as to how high the possibility is that the Creditor will be able to find out the true value of $\mathrm{M}$ (in accordance with the model's assumptions, the probability that the Creditor will be able to find out the exact value of $M$ is $1-r$ ), but also by another question - that as to what the Manager may know about the actual estimation of the value of $M$ having been made by the Creditor. Therefore, two types of information structures are distinguished: those where the Manager at moment $t=1$ knows only structural characteristics $(1-r)$, that is, only the probability that after the realization of a random value of $M$ the Creditor, shortly after the Manager, will be able to determine its value (this type of information in named "soft information" by the authors), and those where the Manager, by taking advantage of the existing economic institutions, is able to know exactly the Creditor's notions as to the value of $\mathrm{M}$ (hard information).

The classification of economic, or, more exactly, financial systems in this paper is rather traditional; the authors apply well-known schemes

\footnotetext{
${ }^{40}$ Berkovich E., R. Israel Optimal Bankruptcy Laws Across Different Economic Systems. "The Review of Financial Studies", 1999. Vol. 12, pp. 347-377.
} 
suggested in the mid-1990s by F. Allen and D. Gale ${ }^{41}$. The following main groups are singled out:

1. Systems based on the capital market's functioning. This type of the economy is characterized by the greatest "depth" in the development of financial markets, in particular the securities markets. The best example of such a system, in the authors' opinion, is the US economy. In these systems, soft information structures prevail, while probability $(1-r)$ must be high enough.

2. Systems where the central role is played by large financial intermediaries, primarily banks (in the terminology of Allen and Gale, "the German model"). Owing to active monitoring, banks possess a vast body of information, which, according to the authors, predetermines high values of probability $(1-r)$. At the same time, close economic links between banks and non-financial companies make it possible to assume that there exists the prevalence of hard information structures.

3. Systems characterized by a comparatively low level of development of financial markets (Under-Developed Systems). The main bulk of the financing relied upon by commercial and industrial companies is provided by banks. However, the informational content of the process being formed in different sectors of the nascent financial markets turns out to be scarcer; also, the companies' reporting is less transparent, and there are no reliable ratings. All this must induce comparatively lower values of structural characteristics $(1-r)$. On the other hand, the CEOs of non-financial companies have clear notions as to the creditors' possible sources of information; also, these CEOs often have secure ("personal") connections with banks. Consequently, here the prevalence of hard information structures may also be assumed.

By plotting values $(1-r)$ on $\mathrm{X}$ axis, and specific weight of hard information, $h$, on $Y$ axis, the author can characterize the relations developing between different systems in the following way ${ }^{42}$ (see fig. 1):

\footnotetext{
${ }^{41}$ Allen F., D. Gale A Welfare Comparison of the German and U.S. Systems. - "European Economic Review", 1995. Vol. 39, pp. 179-209. Более подробно см. Allen F., D. Gale "Comparing Financial Systems" MIT Press: Cambridge, 2000.

${ }^{42}$ Berkovich E., R. Israel Optimal Bankruptcy Laws Across Different Economic Systems. "The Review of Financial Studies", 1999, Vol. 12, p.p. 368.
} 


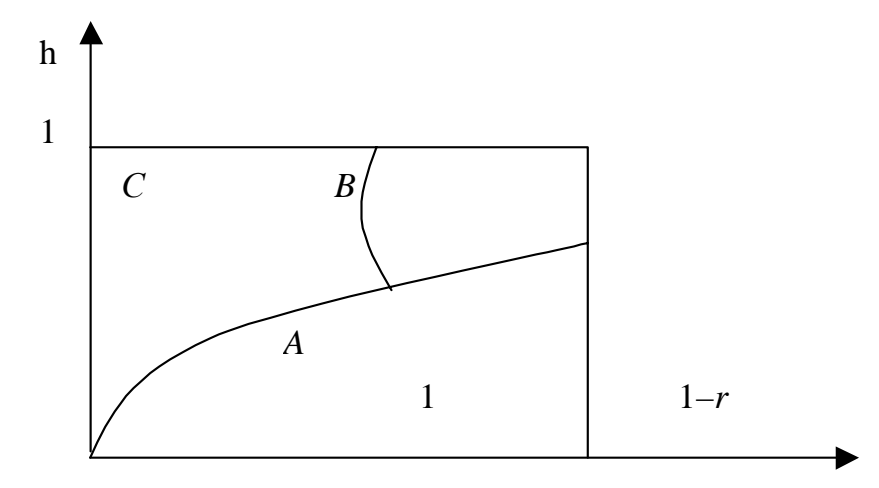

Fig. 1. Information structures in different economic systems

Area $A$, according to the authors, must characterize economic systems based on the capital market's functioning; area $B$ - economic systems where the central role is played by banks; area $C$ - systems where a comparatively lower level of financial markets' development can be observed.

In actual practice, bankruptcy's characteristics, naturally, cannot be reduced just to an unlucky choice of a plan and the possibility (or impossibility) to conceal from the Creditor, for a certain period of time, the information concerning the plan's quality. In real life, both the sources of a company's insolvency and the relations developing between the interested parties, as noted earlier, are far more variable and complex. Nevertheless, in the model under consideration the authors have succeeded in stating certain peculiar features of the relationship between the Manager and the Creditor. Besides, the model is of a rather general character: bankruptcy is only one of the outcomes that can potentially be realized in the course of the discussed interaction between the said actors. So, let us make up a short list of the numerous conclusions that can be drawn on the basis of this model.

Two mechanisms of bankruptcy can be singled out: 1) the one corresponding to the creditor's strategy, and 2) the one corresponding to the debtor's strategy. For a system where the central role is played by banks, the optimal procedures envisage only the mechanism corresponding to the creditor's strategy. This mechanism is determined as follows. After the Creditor has initiated the proceedings in bankruptcy, the Manager is allowed to submit his proposals concerning the future 
destiny of the bankrupt company. If the Creditor rejects these proposals, the court makes the decision that the company be liquidated, and utilizes the incomes from the market sale of the bankrupt's assets for repaying its debts. If the project submitted by the Manager has satisfied the Creditor, it becomes the basis for a new credit contract.

For economic systems based on the capital market's functioning, the optimal bankruptcy procedures envisage that the court resorts to the mechanisms which correspond to the creditor's strategy. More complex (randomized) procedures are envisaged for the instance when a company's bankruptcy is declared by the Manager. With probability $(1-r)$, the court resorts to the same mechanism, corresponding to the creditor's strategy, and with probability $r$ applies the mechanism corresponding to the debtor's strategy. In the latter case, the roles become reversed: the mechanism corresponding to the debtor's interests implies that in accordance with the court's decision the Creditor submits for the Manager's consideration the project for settling the problems that have arisen. If such a project is to the Manager's satisfaction, the claims of the owners of debt obligations are considered to have been satisfied, and the suggested project lays the foundation for a new credit contract. If the Manager rejects the Creditor's proposal, the former credit contract remains in force ${ }^{43}$.

For underdeveloped systems, the optimal bankruptcy procedure does not require any randomization - it simply implies separate application of the procedures described: in those instances when the proceedings in bankruptcy are initiated by the Creditor, the court must trigger a mechanism compatible with the creditors' strategy, whereas when the initiator is the Manager, the mechanism must be compatible with the debtor's strategy. It is assumed that the personnel, which in this system has monopoly over the access to information, can realize this strategic advantage and resort to the bankruptcy mechanism which best corresponds to the debtor's interests.

\footnotetext{
${ }^{43}$ Note a curious consideration that can be found in these recommendations. In the latter of the cases under study (bankruptcy is declared by the Manager; a mechanism corresponding to the debtor's strategy is put into action, whereas the Manager refuses to accept the creditors' proposal; in this event, the creditors may have an interest in the continued functioning of a non-profitable company). The Creditor is obliged to pay a certain fine. In accordance with this model's logic, this must undermine the interest of the creditors in the continuation of the inefficient functioning of the borrower company.
} 
The analysis of situations in the systems with nascent financial markets seems to be somewhat superficial - anyway, not touching upon the essence of the most serious problems faced by the economy in transition. Under the conditions when property rights are not consistently and clearly enough determined by legislation, and the judicial system is corrupt and inefficient (including the system of bankruptcy commissioners), bankruptcy procedures inevitably become the embodiment of abuse and an instrument applied in the struggle for redistribution of property and shareholder control. In more detail these issues will be dealt with in the next sections; here we are simply going to note the role of some of the requirements imposed by the optimal bankruptcy procedures.

In the described bankruptcy practice, when it is applied in a developed market economy, and especially - in projects designed to further reform this practice, the range of powers and the ability to make independent decisions are reduced to a minimum. The act of bankruptcy as such represents, in fact, a signal informing that the State is not going to predetermine the outcome of the emerging conflict in any way - and will not support an insolvent company by the government funds, or enforce its closure. The arising losses must be borne by (and somehow distributed between) private parties - the company's owners and creditors.

The procedure for settling this conflict implies, first of all, that the debtor and creditors must have every possibility for achieving a mutual agreement. In such instances, any subsequent application of bankruptcy procedures becomes superfluous.

If, however, there is no possibility to avoid court proceedings, the solution to the problem associated with a possible property and control redistribution is sought along the lines of finding a mutually beneficial equilibrium of interests, and through applying various mechanisms of checks and balances. By way of illustration, it will suffice to refer to the abovesaid considerations determining "the optimal bankruptcy procedures" (those compatible with the interests of both the creditors and the debtor). Each of the conflicting parties is granted certain opportunities for withdrawal, which are not the same in different economic systems: thus, one of the parties offers its own plan for the conflict's settlement, and this plan cannot be accepted without the other party's approval. Such an approach imposes serious barriers against a possible 
violation of property rights and against bankruptcy being applied as an instrument for arbitrary redistribution of property and shareholder control.

However, the procedure cannot be limited to bilateral bargaining. Wherever possible, economically reasonable bankruptcy procedures appeal to competition mechanisms. Efficient solutions in this context most often are associated with widening the range of information being collected and processed, as well as with the choice of the best plan, based on multi-step market auctioning.

The potential distribution of options with different premiums between the interested parties is also aimed at reducing the "rigidity" of these procedures. Owing to such schemes, the degree of participation of each of the parties in settling the issue of whether to reorganize or liquidate a bankrupt company directly depends on their decision to use (or not to use) the options granted, and this, in the final analysis, is regulated by the situation developing on the market and the expectations of the parties involved.

The courts of justice (and genuinely independent experts) are assigned the roles of primarily an organizer and coordinator of these procedures. The optimal bankruptcy rules and the reforms proposed in this sphere most often rely on the application of efficient self-regulation mechanisms, where the process' outcome is determined by the results of bidding and by market forces, and is not reduced to arbitrary decisions of the judicial and legal agencies (or the executive authority, when it intrudes in this sphere). The bankruptcy rules as such, as well as the competition procedures to which these rules are applied, limit the sphere of activity and the powers of the judicial agencies.

The expansion of these powers seems especially dangerous in situations when the arbitrage courts actually depend on the regional or federal administration. Thereby the opportunities for interested parties to influence the process' outcome through direct bribing or the proposals "to trade services" are also expanded ${ }^{44}$.

\footnotetext{
${ }^{44}$ Thus, in a case when proceedings in bankruptcy are initiated with the goal of property redistribution, delegating extensive powers to the bankruptcy commissioner at the initial stages (while the grounds for initiating such proceedings are being investigated) may result, as shown by experience, in a situation when CEOs, with their own gains in mind, "increase the defendant's insolvency".
} 
In a number of instances, an important role can be played by factors associated with political engagements (thus, representatives of judicial agencies, especially the "older-generation" judges, are quite often opposed to transfers of large enterprises into the hands of foreign owners, "oligarchs", etc. $)^{45}$. Instead of being an instrument for economic recovery, bankruptcies become simply a tool for achieving transient political goals.

Bankruptcy regulation existing in some countries with nascent financial markets impose strong limitations on the real opportunities that can be opened not only by auction bidding, but also by bilateral compromise settlements between the participants (earlier, much attention has been given to the important place they occupy, e.g., in the US bankruptcy practices). It is symbolic that negotiations between creditors and the CEOs of a bankrupt company do not play any serious role not only in many transition economies, but also in the countries of South-East $\mathrm{Asia}^{46}$. It is these procedures, vastly limiting the performance of competition mechanisms, that open the ways for "external pressure", corruption and inefficient administration.

An optimal functioning of property rights must imply, in particular, an efficient protection of a bankrupt company's property from misappropriation. It has already been noted (see Section 1) that even in a developed economy there may appear incentives for the CEOs of a company on the verge of bankruptcy to withdraw the largest possible part of its assets. Therefore, one more function of the judicial authorities would be to actively and carefully protect this company's property from covert plundering. This task becomes even more important in countries with economies in transition where, due to the imperfection of legislation designed to regulate property rights and to inefficient control mecha-

\footnotetext{
${ }^{45}$ The opportunities for arbitrary administrative decisions become even greater when factors like a company's (or enterprise's) "social significance" are made relevant in the course of these procedures. By compiling special "social significance lists", the implementation of the strategy pursued not by the third, but already by the second (executive) authority, as well as the partied hiding behind it, can be made easier.

${ }^{46}$ See, e.g., Claessens S., S. Djankov, D. Klingebiel "Financial Restructuring in East Asia: Halfway There?" in: "Resolution of Financial Distress: An International Perspective on the Design of Bankruptcy Laws" ed. by S. Claessens, S. Djankov, A. Mody. World Bank: Washington, 2000.

Claessens, Djankov, Klingebiel, 2001.
} 
nisms, asset withdrawal begins long before the initiation of bankruptcy procedures.

This factor is also responsible for the widespread practice of "premeditated bankruptcies", when the CEOs (often performing, in fact, the functions of a company's owners), having withdrawn much of its assets, resort to bankruptcy procedures in order to get rid of their arrears of payments due to the State and private partners. In such situations, the judicial authorities, naturally, are unable to recover (in full) the money due against these liabilities, the economic structures having become emptied from inside ${ }^{47}$.

The problem associated with asset withdrawal from companies prior to premeditated bankruptcies is, certainly, far broader than the issues discussed here, and requires a special study. Still, we should like to note three points that have a direct bearing on bankruptcy procedures.

Firstly, a bankruptcy commissioner's independence is by no means an "independence" from the law, which requires that property rights be protected in every possible way. The powers of bankruptcy commissioners, after the decision concerning the liquidation of a bankrupt company has been made, must be sufficient for preventing asset withdrawal to be effectuated by its owners or CEOs. In this connection, an optimal bankruptcy mechanism must envisage not only strict responsibility of the commissioners, but also an efficient supervision over the performance of their functions.

Secondly, clarity and transparency of reporting, as well as of the documents concerning the registration of the bankrupt company's property, are among the most necessary prerequisites for adequate protection of creditors' interests (and for a realistic assessment of the plans for the company's reorganization). Meanwhile, it is exactly the interest in asset withdrawal that causes incorrect reporting, as well as deliberately complicated and incomplete information concerning the company's registered property.

\footnotetext{
${ }^{47}$ Any attempts to struggle against this phenomenon by applying purely administrative measures, for example by punishing for "premeditated bankruptcy", have turned out to be purely declarative, since in most instances the actions that may result in a company's bankruptcy can be likened to an erroneous choice of a strategy and undequate professional qualification of the managerial personnel.
} 
And thirdly, the need to protect property rights has also resulted in the requirement that bankruptcy procedures be completed within the shortest possible period of time. Thus, the procedures established in some West European countries prescribe that CEOs register their company as bankrupt immediately after its insolvency has been revealed. Serious sanctions, even criminal responsibility and imprisonment, are envisaged for those CEOs who have allowed a substantial delay in bankruptcy registration. Very short periods for the judicial procedures in bankruptcy are established as a mandatory norm. The longer the period of the proceedings in bankruptcy, the slimmer is the chance that a bankruptcy commissioner will be able (and genuinely willing) to prevent covert plundering of the company's property, and the less secure are property rights.

During the past century, several serious studies were undertaken in order to see how legal structures influence the processes of economic growth and the development of financial markets ${ }^{48}$. One of the areas for such research is the analysis of bankruptcy procedures and their impact on the debt market. Based on the results of those studies, R. La Porta and F. Lopez-de-Silanes conducted a comparative analysis of the legal norms on bankruptcy existing in 49 countries. In order to assess the degree of protection of creditors' rights in each of these countries, four indices were applied in the analysis:

1) Is there an automatic suspension, for a certain period of time, of the claims to the debtor after the proceedings in bankruptcy have been initiated? (no - 1 point, yes - 0),

2) Is there a priority for satisfying the claims of the creditors with mortgage notes? (legislation does envisage such a priority - 1 point, no priority -0),

3) Can the plans for reorganizing a bankrupt company be accepted for consideration without the creditors' approval? (no - 1 point, yes - 0 ); and, finally,

\footnotetext{
${ }^{48}$ See, e.g., La Porta R., F. Lopes-de-Silanes, A. Shleifer, R. Visny Legal Determinants of External Finance. - "The Journal of Finance", 1997. Vol. 52, pp. 1131-1150; La Porta R., F. Lopes-de-Silanes, A. Shleifer, R. Vishny Law and Finance. - "Journal of Political Economy", 1998. Vol. 106, pp. 1113-1155; La Porta R., F. Lopes-de-Silanes, A. Shleifer, R. Vishny Investor Protection: Origins, Consequences, and Reform. - "Journal of Financial Economics", 2003; Beck T., A. Demiguc-Kunt, R. Levine Law, Endowments and Finance. "Journal of Financial Economics", 2003. Vol. 58, etc.
} 
4) Can the CEOs of a bankrupt company handle its property while making the decision as to the company's reorganization? (no - 1 point, yes -0$)$.

After comparing the answers to these questions offered by legislations existing in different countries, it can be stated than in many countries with nascent markets the creditors' rights appear to be inadequately protected. Thus, the total number of points in respect to Mexico, Columbia, Peru and the Philippines amounts to zero (none of the requirements is satisfied), in respect to Argentina, Brazil, Greece and Portugal - to one, while in the UK - the country which serves as "a standard" for creditors' rights protection - it is as high as four (all the four requirements are satisfied).

It has already been noted above that creditors' rights protection represents only one of the necessary aspects of an optimal bankruptcy procedure, and so it would hardly make sense to limit this analysis just to the results of the comparison described above, the problem in itself being far more complex. It would suffice to note that in France, where bankruptcy procedures are clearly biased toward the reorganization of bankrupt companies, the total number of points is also zero, whereas in the USA it is 1, and in Germany - 3.

The formally similar indices may mask the existence of qualitatively different processes. The low numbers of points calculated for countries with nascent markets have demonstrated (in contrast to the majority of developed countries) unreliable credit relations and inadequate efficiency of bankruptcy procedures. In Mexico and Peru (as well as in Russia) private creditors can recover, in the course of bankruptcy, no more than 3-6\% of their loaned funds. As for bankruptcy procedures as such, in Mexico and Peru they may last for a period of between three and seven years, while in Thailand - for more than ten years.

In countries like the USA and France, certain limitations imposed on the creditors' rights (at least as believed by those who support the existence of such procedures) are capable of promoting the opportunities for maintaining and reorganizing a bankrupt company. In countries with nascent markets, including many transition economies, "reorganization" procedures are quite often applied to "non-viable" economic structures emptied by the insiders. In such instances, not only reorganization, but at least the revival of economic operations and the mainte- 
nance of "socially relevant" enterprises represents a very hard task to achieve. As noted by R. La Porta and F. Lopez-de-Silanes, without an efficient bankruptcy procedure the enterprises that face serious financial trouble may stay in limbo, being able neither to restructure their debts, nor to mobilize the resources needed for implementing new projects $^{49}$.

The inadequate efficiency of property-rights protection, which reveals itself, in particular, in less than optimal bankruptcy procedures, may unfavorably influence the processes of economic growth. Some areas of such influence have been already mentioned in our previous discussion; by way of conclusion, we are going to simply list those "channels of influence" that are believed to be the most important ones.

Due to the uncertainty in respect to property rights, which temporarily becomes obvious in a situation when a borrower company becomes insolvent, bankruptcy becomes a potent instrument of redistributing owners' and shareholders' control. As a matter of fact, when bankruptcy practice is less than optimal, such redistribution may result, and actually does result, in inefficient decisions. The evidence of this is the tendency to create huge and poorly managed "economic empires" (conglomerates), which can be seen in some countries; these "empires" grow at the expense of a variety of enterprises, the control over which has been achieved as a result of "subjecting them to bankruptcy".

On the other hand, too soft ("sparing") bankruptcy procedures can, in fact, undermine the action of the mechanisms designed to ensure marker discipline, and under conditions of an economy in transition - to impede the transition from soft to hard budget constraints ${ }^{50}$. The possibility to accumulate stale debts for a long period of time can create especially favorable conditions for destructing companies "from inside" and withdrawing a part of assets from a company which continues to function despite its revealed insolvency. The devastating "epidemics of non-payments", which have sometimes been springing up in Russia

\footnotetext{
${ }^{49}$ La Porta R., F. Lopes-de-Silanes "Creditor Protection and Bankruptcy Law Reform" in: "Resolution of Financial Distress: An International Perspective of the Design of Bankruptcy Laws" Ed. by S. Claessens, S. Djankov, A. Mody. World Bank Washington, 2001, p. 79.

${ }^{50}$ See, e.g., Roland G. "Transition and Economics: Politics, Markets, and Firms" The MIT Press: Cambridge, Mass 2000, Chapter 9.
} 
and some other countries with economies in transition, considerably restrained the development of market relations ${ }^{51}$.

The limited possibilities for insuring credit risks by applying "purely market" mechanisms have already been mentioned. The rules for regulating the problems that inevitably arise in the event of a company's insolvency that are centralized, equal for all the participants, and stable, have always been regarded as one of the most important components of the infrastructure ensuring an efficient functioning of financial intermediaries and the securities market. Therefore, less than optimal bankruptcy procedures represent a serious obstacle in the way of the development of the debt market, which, in its turn, considerably limits the opportunities for financing new capital investments.

\footnotetext{
${ }^{51}$ See Coricelli F., G.-M. Milesi-Ferreti On the Credibility of "Big Bang" Programs: A Note on Wage Claims and Constraints in Economy in Transition. - "European Economic Review", 1993. Vol. 37, pp. 387-395; Karpov P. "O prichinakh nizkoi sobiraemosti nalogov (neplatezhei fiskal'noi sisteme), obshchikh prichinakh "krizisa neplatezhei" i vozmozhnosti vosstanovleniia platezhesposobnosti rossiiskikh predpriiatii". Otchiot mezhvedomstvennoi balansovoi komissii." "On the causes of low tax collection (non-payments in the fiscal system), the general causes of "the crisis of non-payments" and possibilities of restoring solvency of Russian enterprises". Report of the Inter-Departmental Balance Commissions). Moscow, 1997.
} 


\section{Chapter 2. Main legal phases in the development of the institution of insolvency in contemporary Russia}

\subsection{Traditional models and specific features of the economy in transition}

Regulation of insolvency represents the most rapidly developing area of law in foreign developed countries, while the national economies are promoting continual updating of appropriate norms ${ }^{52}$. The main purpose of the institution of insolvency is to ensure a predictable distribution of risks for the creditors. Theoretically, the legal norms designed to regulate insolvency of enterprises may pursue the following goals:

- $\quad$ protecting creditors' rights, ensuring financial discipline, improving the reliability of credit circulation;

- lowering the level of economic risks in the economy through liquidating inefficient works;

- ensuring redistribution of industrial assets in favor of efficiently operating enterprises, developing competition;

- effectuating reorganization of enterprises and their financial restructuring;

- improving the quality of corporate governance, replacement of "inefficient" owners;

- $\quad$ ensuring the replacement of poorly qualified managers, and introducing a rational management system at enterprises.

It should be noted that the effectuation of bankruptcy procedures always means losses to the creditors, the debtor enterprise, its owners, and the State. Foreign countries with developed economies are no exception in this respect. The possibilities offered by bankruptcy in terms of reforming a business and replacing its "inefficient" owner are quite limited, its main purpose being that of liquidating inefficient sources of production, redistributing irrationally used assets and lowering the economic risks in the economy.

\footnotetext{
${ }^{52}$ See Teliukina M. Osnovy konkursnogo prava (The basics of bankruptcy law). - M., Volters, Kluver, 2004, p. 77-82. Stepanov V. Nesostoiatel'nost' (bankrotstvo) v Rossii, Frantsii, Anglii, Germanii. (Insolvency (bankruptcy) in Russia, France, England, Germany). M., "Statut", 1999.
} 
The experience of foreign developed countries does not make it possible to unequivocally assert that the regulation of insolvency should be based on creditors' priority. A characteristic feature of most of the contemporary developed systems for regulating insolvency consists in the presence and further development of rehabilitative procedures designed to maintain a business, as an addition to the classical bankruptcy mechanism that involves the selling-out of the debtor's assets as part of bankruptcy procedures.

In principle, all insolvency and bankruptcy systems may be subdivided into two mutually opposing categories: pro-debtor (USA, France) and pro-creditor (UK, Germany) ${ }^{53}$.

Thus, the German model is oriented toward improving the efficiency of satisfying creditors' claims, the rehabilitative procedures being aimed at maximizing the debtor's assets for their subsequent redistribution among the creditors. The typical UK model is oriented toward protecting credit circulation and creating efficient effectuation of bankruptcy procedures, the enterprise is being controlled by a third party acting on behalf of the creditors. An obvious drawback of this model is the explicit promotion of an enterprise's liquidation instead of its rehabilitation, since the creditors are primarily interested in selling the assets of a company in financial trouble, and not in its rescue.

In the USA, and even more so, in France, the commonly applied models are based on a combination of two sets of goals: those of achieving stability and consistent economic growth (macroeconomic problems), and those aimed at creating efficient mechanisms for distributing debtors' assets. In France, in particular, the institution of insolvency is to a substantial degree pro-debtor, being focused on restructuring. US legislation allows a debtor to retain control over an insolvent juridical person, and grants the former an exclusive right to submit its own reorganization plan within a specified period of time. The distribution of rights in favor of the debtor has largely been determined by a political choice, since the preservation, as a going concern, of a company against which a petition in bankruptcy has been filed, instead of its

\footnotetext{
${ }^{53}$ See also Radygin A.D., Gontmakher A.Ye., Mezheraups I.V., Turuntseva M.Yu. Ekonomiko-pravovye factory i ogranicheniia v stanovlenii modelei korporativnogo upravleniia (The economic and legal factors and limitations during the consolidation of corporate governance models). M., IET, 2004.
} 
annulment by way of liquidation, is being recognized as a priority. An important limitation of this model is the existence of an opportunity for the debtor to misuse the granted rights.

All intermediate models differ primarily from the point of view of the degree of equilibrium being achieved between violating creditors' rights and maintaining an enterprise as a going concern.

According to the EBRD's estimates, legislation on bankruptcy procedures in the countries with economies in transition is less developed than legislation addressing other areas of commercial law. In particular, this is true of the efficiency with which this legislation is being applied. Proceedings in bankruptcy often are very protracted and yield no actual results. The qualifications of the appointed external administrators, as well as the scope of their powers, are also quite often questionable. Despite the serious steps that have been taken in the countries of Central and Eastern Europe, the Baltic states and the CIS in order to improve both existing legislations and the practices in the sphere of corporate bankruptcies, no significant improvements have been observed ${ }^{54}$.

At the same time, those specific objective limitations that characterize the situations in Russia and some other countries with economies in transition and are impeding an effificnt and mass-scale application of this mechanism are also well-known:

- an unfavorable financial status of a considerable number of newly created corporations;

- the traditions of soft budget constraints;

- the preservation of a large number of corporations where the State has a stake;

- the need for an adequate and highly qualified executive and judicial infrastructure;

- socio-political obstacles that prevent the application of genuine bankruptcy procedures to loss-making corporations, especially if they are very large or city-forming enterprises;

- multiple technical difficulties associated with objective estimations of the financial status of potential bankrupts;

- corruption and other criminal aspects of this problem, especially those associated with property redistribution.

${ }^{54}$ See EBRD Transition Reports, 1999-2003. EBRD. 
Pro-debtor bankruptcy legislations exist in Uzbekistan, Moldova, Lithuania, Ukraine (although in the latter case the overall pro-debtor orientation is combined with some important pro-creditor provisions).

The systems of bankruptcy law existing in Azerbaijan, Kazakhstan and Georgia can be characterized as pro-creditor. Strong pro-creditor elements also exist in Latvia's and Estonia's legislations.

Initially, the countries of Central and Eastern Europe and the CIS faced the necessity of a choice to be made between these two models. However, since in the majority of developed countries a mixed model is being applied, which incorporates elements characteristic of both the USA and the UK in order to achieve a proper balance between creditors' and debtors' rights (thus, the management of an enterprise undergoing the procedure of bankruptcy is usually delegated to a commissioner who is neutral in respect to both the creditors and the debtor), many countries with economies in transition have also attempted to follow this example.

The system of bankruptcy law existing in Russia may be called neutral, with a considerable pro-debtor bias (since 2002).

In this connection, so far three main phases in the development of the institution of insolvency in Russia can be distinguished:

- from the end of 1992 till early 1998 - the period when the Law of the Russian Federation of 11.19.1992, No. 3929-1, "On insolvency (bankruptcy) of enterprises" (hereinafter - the $1^{\text {st }}$ Law on bankruptcy) was in effect;

- from early 1998 till the end of 2002 - the period when the Federal Law of 01.08. 1998, No. 6-FZ, "On insolvency (bankruptcy)" (hereinafter - the 2nd Law on bankruptcy) was in effect;

- from the end of 2002 till the present time - the period of the Federal Law No. 127-FZ "On insolvency (bankruptcy)" (hereinafter - the $3^{\text {rd }}$, or New, Law on bankruptcy) being in effect.

The first phase (1993-1997)

For fairness' sake, it should be noted that the legal history of bankruptcy in Russia had begun prior to the onset of the first phase, as specified above. The first set of key provisions on bankruptcy - in particular, those concerning the application of rehabilitative procedures to state enterprises, appeared in the RF President's Edict of 14 June 
1992, No. 623, "On the measures designed to support and rehabilitate insolvent state enterprises (bankrupts) and the application of special procedures to them". The Edict envisaged the administrative procedure for state enterprises (as well as those where the State's stake amounted to $50 \%$ or more) being deemed insolvent. After such enterprises had been recognized as bankrupt, the application to them of "special liquidation procedures, including reorganization and other measures aimed at rehabilitating the economic and financial status of enterprises", was envisaged. It is noteworthy that this Edict is still formally being in force.

One more act preceding the $1^{\text {st }}$ Law on bankruptcy was the ordinance of the RF State Committee for Managing State Property of 5 November 1992, No. 717-r, "On approving the Model Provision on conducting a tender to sell a bankrupt enterprise and its property". This ordinance was adopted in order to develop the provisions established by the Presidential Edict of 14 June 1992 No. 623. The Model Provision envisaged two types of an enterprise's sale: the sale in full, when it remained a single property complex with the same specialization as before, or the sale of an enterprise's property part by part. The selling-out of an enterprise was envisaged in the event when the attempt to sell it in the course of a commercial tender had been unsuccessful $\left.\right|^{55}$.

The $1^{\text {st }}$ Law on bankruptcy was enacted in Russia approximately at the same time as in other countries with economies in transition. Though during 1995-1997 the number of petitions in bankruptcy submitted to the arbitrage courts demonstrated a noticeable growth, the procedure of bankruptcy as such did not become as common in Russia as in other countries with transition economies. This law was based on the principle of unpayability, stipulating that, when the ratio between the values of assets and liabilities is being estimated, and if the amount of credit indebtedness is higher than the value of an enterprise's estate, that enterprise is recognized as insolvent on the balance-sheet basis.

The $1^{\text {st }}$ Law on bankruptcy is usually commented upon as very imperfect. An overwhelming majority of authors share the opinion that this law is too lax in respect to debtors. According to V. Vitrianskii, the notion

\footnotetext{
${ }^{55}$ Yu. Svit. Vosstanovitel'nye protsedury - sposob predotvrashcheniia bankrotstva. (Rehabilitative procedures - a way of preventing bankruptcy). - Rossiiskaia lustiysiia, No. 3, 1998.
} 
and indicia of bankruptcy as stated in the $1^{\text {st }}$ Law have become outdated and incompatible with the modern ideas of property turnover and the requirements to the participants in this turnover. In this Law, insolvency (bankruptcy) was understood as a debtor's inability to satisfy a creditor's claims concerning payments for goods (or works, services), including an inability to make mandatory payments to the budget and offbudget funds, due to the debtor's liabilities being higher than its estate's value, or due to an unsatisfactory structure of the debtor's balance sheet.

It was not enough that a debtor had for a long time (more than three months) failed to pay debts, and was unable to pay in principle; in order to recognize a debtor as bankrupt, a court was obliged to review the composition and value of its estate, as well as to estimate the structure of its balance sheet from the point of view of asset liquidity. And only when credit indebtedness was higher than the balance-sheet value of total assets could a debtor be declared bankrupt. This approach made possible a situation when persons (organizations and entrepreneurs) incapable of paying for the goods, works and services supplied to them could become participants in property turnover, as a result of which their contractors were becoming insolvent, too.

On the other hand, the conditions were thus created, under which those directors of commercial organizations who "knew the law" to a certain practical degree could, without paying their debts, use the funds, earmarked exactly for that purpose, as their own circulating assets, just taking care that their total credit indebtedness not become higher than their organization's total assets value. The then existing legal notions and indicia of bankruptcy were protecting dishonest debtors and thus undermined the principles of property turnover ${ }^{56}$.

The practice of applying this law has demonstrated that creditors' rights were being significantly restricted due to the difficulties associated with the estimation of true estate value by the arbitrage court, and, therefore, to the delayed decisions to deem debtors to be bankrupt. In the Russian situation, when the balance-sheet value of property does not reflect its real value, when it is very difficult to estimate the liquid part of a debtor's assets, and when accounting documentation is unre-

\footnotetext{
${ }^{56}$ V.Vitrianskii. Novoe zakonodatel'stvo o nesostoiatel'nosti (bankrotstve). (New legislation on insolvency (bankruptcy). - Khoziaistvo i pravo. No. 3, 1998.
} 
liable, such an approach in some instances resulted in arbitrary or unpredictable decisions having been made by arbitrage courts ${ }^{57}$. The then existing legal notions and indicia of bankruptcy were protecting dishonest debtors and thus undermined the principles of property turnover ${ }^{58}$.

During this phase, the most important external factors determining the interests of conflicting parties in the sphere of insolvency were as follows:

- $\quad$ as the grounds for declaring an enterprise bankrupt, an excess of its total debts over the value of its property was established, which created considerable problems in respect to initiating bankruptcy procedures;

- a considerable number of large attractive enterprises remained in the State's or mixed ownership;

- the economy was characterized by a high level of barter transactions, as well as by an acute problem of non-payments, including debts to the State in respect to taxes and mandatory payments.

Among the reasons for insufficiently active application of the 1992 Law on bankruptcy ${ }^{59}$, the lack of a systematic practice of applying bankruptcy procedures on the part of the State as a tax creditor was pointed out, as well as its orientation towards the use of certain instruments like imposing fines for delays in payment. It was senseless for ordinary creditors to initiate bankruptcy procedures, because all liquid assets in this case were used to repay the stale debts to the State as a preferred creditor.

In 1995-1997, certain trends appeared that manifested an expansion of the scope of applying bankruptcy procedures to potentially highly profitable enterprises, as well as to those likely to receive a big

\footnotetext{
${ }^{57}$ See, e.g., Zakliucheniie po zakonoproektu "O vnesenii izmenenii i dopolnenii v Federal'nyi zakon "O nesostoiatel'nosti (bankrotstve)". (An estimation of the draft law "On insolvency (bankruptcy)"). Rossiiskoe obshchestvo nezavisimykh ekspertov i antikrizisnykh upravliaiushchikh (Russian Society of Independent Experts and Anti-Crisis Managers). February 1999.

${ }^{58}$ V. Vitrianskii. Novoe zakonodatel'stvo o nesostoiatel'nosti (bankrotstve). (New legislation on insolvency (bankruptcy). - Khoziaistvo i pravo. No. 3, 1998.

${ }^{59}$ O. Pak'e, R. Seligman. Ugroza bankrotstva i restrukturizatsii (na primere moskovskikh predpriiatii). (The threat of bankruptcy and restructuring (as exemplified by Moscow enterprises) - Predprinimatel'stvo v Rossii, 1997, No. 2.
} 
order. Some experts ${ }^{60}$ associated this with the desire of the Federal Administration on Insolvency to accelerate the process of privatization.

Due to the substantial limitations of the $1^{\text {st }}$ Law on bankruptcy, it produced no noticeable impact on the Russian economy. According to the authors of the report published by the Russian-European Center for Economic Policy ${ }^{61}$, bankruptcy became neither a serious threat for inefficient directors of the majority of Russian enterprises, nor a means for ensuring the protection of rights of external creditors.

The second phase (1998-2002)

As the main reason for the adoption of the 2nd Law on bankruptcy, experts have most often pointed out the low efficiency of the previous law, resulting from its excessively lax attitude toward debtors, and as the main innovation - a fundamental change in the approach to determining the criteria for insolvency (bankruptcy) of debtors - juridical persons, which considerably strengthened the position of creditors. The 2nd Law on bankruptcy was founded on the principle of insolvency: the focus of attention became the inability of an enterprise to timely fulfill its obligations as regards the redemption, and in this instance the enterprise was recognized as insolvent on a cash basis. This resulted in considerable lowering of the barriers for initiating the proceedings in bankruptcy. Therefore, the scope of applying bankruptcy procedures in the economy began to grow rather rapidly.

Experts had warned that the enactment of the 2nd Law on bankruptcy would result in a dramatic rise in the number of bankruptcies, because a majority of Russian companies prior to the year 1998 had accumulated substantial arrears of debt to the federal and regional budgets, as well as to private creditors, due to the absence of efficient regulations concerning bankruptcy. As expected, the number of bankruptcies surged after the 2 nd Law on bankruptcy had come into force.

\footnotetext{
${ }^{60}$ Medlit' s sozdaniiem effektivnogo mekhanisma bankrotstva opasno. Interv'iu s D. Nokologorskim. (It is dangerous to delay the creation of an efficient mechanism of bankruptcy. An interview with D. Nikologorskii). -Rynok tsennykh bumag, 1997, No. 12.

${ }^{61} \mathrm{~K}$. Son in, Ye. Zhuravskaia. Bankrotstvo v Rossii: ni zashchity kreditorov, ni restrukturirovaniia. Spetsial'nyi doklad. - Obzor ekonomiki Rossii. Osnovnye tendentsii razvitiia. $2000 \mathrm{~g}$. (Bankruptcy in Russia: neither creditors' protection, nor restructuring. A special report. An overview of Russia's economy. Main trends of development. 2000). I: Transl. from the English. - M., RETsEP, 2000.
} 
This growth in the number of bankruptcies was interpreted by many experts as an evidence that owing to the enactment of the 2nd Law on bankruptcy the budget restraints for Russian enterprises became harder.

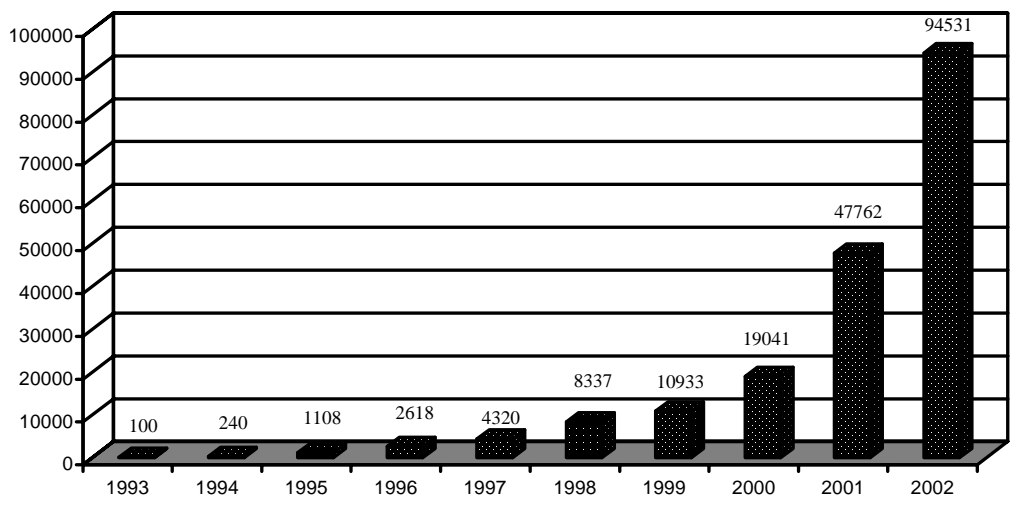

Fig. 2. Numbers of petitions in bankruptcy resulting in initiated proceedings

At the same time, the experience of applying the 1998 Law on bankruptcy demonstrated the simplicity of initiating bankruptcy procedures against large enterprises when their debts were small, as compared to the scope of their business. The reason was that, in accordance with this law, a creditor could petition with the arbitrage court that its debtor be deemed to be bankrupt when the latter had failed to fulfill its obligations during three months, and the amount of debt exceeded 500 minimum salaries. Thus, the principle of insolvency was to a markedly higher degree promoting payment discipline, creating equal opportunities for creditors in respect to initiating a bankruptcy procedure, was not requiring a mandatory high professional qualification for making a court decision concerning a specific case; however, this approach did not take into account the scope of a business or potential cash gaps that might not be necessarily indicative of the enterprise's true inefficiency.

It should be noted that the 2nd Law on bankruptcy also made use, in a "soft" form, of the principle of unpayability. Thus, in accordance with Item 2 of Article 51 of this law, if a debtor possessed a liquid property 
sufficient to redeem its debts, the arbitrage court had the right to suspend the proceedings in bankruptcy, having suggested that the debtor satisfy the creditors' claims within a certain period of time.

The second phase in the development of the institution of insolvency, especially after the 1998 financial crisis, was characterized by a fundamental change in the composition of the main factors influencing the implementation of bankruptcy procedures:

- the "threshold" for initiating bankruptcy procedures was considerably lowered;

- the processes of industrial integration were intensified, while the law-making activity aimed at protecting the interests of minority shareholders became more intense;

- a significant number of enterprises showed production growth, with a still high level of tax arrears $^{62}$; the State had no right of vote when the most important decisions were being adopted by shareholder meetings;

- the system of arbitrage courts was developing, however they were found to be strongly dependent on regional and local authorities;

- problems pertaining to the training of bankruptcy commissioners and their affiliation to certain creditors.

Issues relating to the initiation of the bankruptcy process have, in a variety of ways, been touched upon in a majority of publications concerning legal regulation in the sphere of insolvency. Some categories of the institution of insolvency, like the criteria for and indicia of bankruptcy and the grounds for initiating courts proceedings, are discussed in detail, for example, by $\mathrm{V}$. Vitrianskii ${ }^{63}$, who disagrees with the common point of view that the main reason for the ability, under the 2nd Law on bankruptcy, to have any commercial organization be deemed "to be bankrupt", no matter what the status of its property might be, were the too soft, too liberal criteria of bankruptcy established by this law: the three-month delay in the redemption of a liability in the amount in excess of 500 minimum salaries. Actually, as the author argues, the

\footnotetext{
${ }^{62}$ Budget constraints began to be systematically hardened only from the second half of 2001 onward, due to the then initiated campaign for restructuring enterprises' arrears of debts against mandatory payments.

${ }^{63} \mathrm{~V}$. Vitrianskii. Puti sovershenstvovaniia zakonodatelstva o bankrotstve. (Ways for improving bankruptcy legislation). - Vestnik VAS RF, No. 3, 2001.
} 
amount of a liability and the period of delay in its execution are not the true criteria of bankruptcy, and represent only the external indicia of a debtor's potential insolvency. The true criterion of bankruptcy is a debtor's inability to satisfy its creditors' claims and to make mandatory payments, as established by a court of justice. When this criterion in applied, the conclusion as to a debtor's insolvency is based on the assumption that a debtor who is not making proper settlements with its creditors and failing to pay taxes, evidently, does not possess sufficient liquid property, since any other causes of non-payments are excluded in accordance with the principle of reasonability and honesty of the participants in property turnover. Meanwhile, the law-makers are free to determine those external indicia of a debtor's financial status, in the presence of which creditors have the right to make assumptions as to the debtor's insolvency in respect to property.

Thus, the role of external indicia of bankruptcy is that their presence grants a debtor's creditors the right to make assumptions as to the latter's insolvency. The final and decisive solution is to be made by an arbitrage court, which (and none other!) may declare a debtor bankrupt. Therefore, no less important than the criteria and external indicia of a debtor's insolvency are also the grounds for the proceedings in bankruptcy being initiated by an arbitrage court, in order to declare a debtor bankrupt.

It is exactly this that is regarded by the author as the most serious limitation of the 2nd Law on bankruptcy, its essence being that an arbitrage court operates under the conditions that force it to blindly obey the wishes of the creditors who are initiating the proceedings in bankruptcy. According to this Law, in the presence of external indicia of bankruptcy, which, if desired, can be found in respect to any Russian participant in property turnover, and on the condition that the creditors comply with the basic requirements established by the law concerning the formalization of a petition that a debtor be deemed to be bankrupt, an arbitrage court, on accepting such a petition, must in the shortest possible period initiate the proceedings in bankruptcy. And under the specific Russian conditions, the very fact of the proceedings in bank- 
ruptcy having been initiated against a particular debtor inevitably results in very negative consequences for the latter ${ }^{64}$.

The same point of view is shared by Head of the Department of the Ministry for Economic Development and Trade Ts. Tserenov. In his opinion, there should not be any discussion concerning the indicia of bankruptcy, because this is an issue relating to an enterprise's financial policy. A good administrator must know ALL of his or her financial liabilities, both big and small. At the same time, the initiation of the proceedings in bankruptcy sometimes can be effected on grounds that are not really justified. A creditor may simply file a petition in bankruptcy, and the court will at once initiate the proceedings, thus triggering the procedure ${ }^{65}$.

After the enactment of the 2nd Law on bankruptcy, there was much campaigning in order to demonstrate the "creative potential" of bankruptcy procedures ${ }^{66}$. It was postulated that in $90 \%$ of cases the causes of an enterprise's troublesome situation have their roots in the sphere of business management, and only in $10 \%$ the inherited structure of the economy is to be blamed. Therefore it was hoped that the procedures of external administration would make it possible to dismiss an incompetent manager and replace him or her by a competent bankruptcy commissioner, who would "rehabilitate" the enterprise. Many experts at that time (and some are still doing it) tended to "demonize" the image of a "red director", seeing neither any possible ways for his selfdevelopment nor any instruments for CEOs' replacement that would be an alternative to bankruptcy.

A number of specialists have also noted the problem of premeditated bankruptcy. It can be applied as a measure for protecting the director from shareholders. Managers can relatively easily arrange for their trusted partners to consolidate an enterprise's deliberate debts, buy out its bills and effectuate a bankruptcy procedure, making a rep-

\footnotetext{
${ }^{64} \mathrm{~V}$. Vitrianskii. Puti sovershenstvovaniia zakonodatelstva o bankrotstve. (Ways for improving legislation on bankruptcy). - Vestnik VAS RF, No. 3, 2001.

${ }^{65}$ Institut bankrotstva stanovitsia vsio bolee vostrebovannym ekonomikoi mekhanizmom (The institution of bankruptcy is becoming a mechanism the demand for which is more and more growing in the economy.) An Interview with Head of a Department of the RF Ministry for the Management of State Property Tseren Tserenov. See www.opec.ru.

${ }^{66}$ Gorelov A. O rossiiskoi spetsifike instituta bankrotstva (On the Russian specificity of the institution of bankruptcy). - Rynok tsennykh bumag, 1998, No. 19.
} 
resentative of the former CEOs the new top manager. The representatives of the RF Ministry for the Management of State Property ${ }^{67}$ have stated that bankruptcy is becoming an instrument for protection from the State as an owner. For example, in some instances, when preparing an enterprise for privatization, potential buyers were trying to "knock down" its price by means of threats that bankruptcy procedures could be initiated in respect to the object of privatization; in others, when the State attempted to use its shareholder rights in order to replace a director, the latter initiated bankruptcy procedures against the enterprise in question.

Some representatives of state authorities ${ }^{68}$, as one of the motives for premeditated bankruptcy that appeared after the enactment of the 1998 Law, have named the desire to withdraw the most liquid assets from an enterprise burdened with tax arrears. They associated such opportunities with the State's limitations as a tax creditor in the course of effectuating bankruptcy procedures. As estimated by the Federal Service for Financial Rehabilitation and Bankruptcy ${ }^{69}$, every fifth bankruptcy has the indicia of premeditated criminal actions (in particular, bankruptcy in order to write-off debts).

It should be admitted that the State, in its turn, sometimes resorts to the threat of bankruptcy as an instrument for exerting pressure on an enterprise in order to force it to redeem its tax debts, or for other purposes.

In one of the studies ${ }^{70}$ it has been demonstrated that the danger of bankruptcy of a large regional enterprise results in a merger of the interests of CEOs and those of the regional authorities. Neither of them

\footnotetext{
${ }^{67}$ Bekker A. Pogonshchiki slonov (Elephants' shepherds). (An interview with V. Pyl'nev). Vedomosti, 7.06.2000.

${ }^{68}$ Komarov Yu. Glavnoe - finansovoe ozdorovleniie (The main thing is financial rehabilitation). (An interview with G. K. Tal'). - Zhurnal dlia aktsionerov (Journal for shareholders), 1998, No. 11.

${ }^{69}$ Since September 1993, Russia had the Federal Agency for Issues of Insolvency (Bankruptcy) (FAll) at the RF State Committee for the Management of State Property), in March 1997 the RF Federal Service for Insolvency and Financial Rehabilitation (FSIFR) was created, and in June 1999 it was transformed in the RF Federal Service for Financial Rehabilitation and Bankruptcy (FSRFB).

${ }^{70}$ Lambert-Mogilianskaia A., Sonin K., Zhuravskaia Ye. Politicheskie aspekty bankrotstva v perekhodnyi period (The political aspects of bankruptcy during transition). - M., RussianEuropean Center for Economic Policy, 2000.
} 
have an interest in the enterprise's liquidation or fundamental restructuring, since the former do not want to make efforts in order to reform its business, while the latter are afraid of the possibility to lose tax revenues, jobs and the public services being rendered, and do not think it necessary to contribute to the redemption of the enterprise's debts to creditors from other regions.

However, it should be recognized that the behavior of regional authorities in respect to bankruptcies of enterprises is by no means uniform. Thus, according to representatives of the Federal Service for Financial Rehabilitation and Bankruptcy, it is often difficult to investigate the cases of premeditated and fictitious bankruptcies because of the pressure exerted by local authorities, since the latter regard the withdrawal of assets, with subsequent foundation of a new enterprise on their basis, to be an important mechanism for improving business efficiency.

During the part few years, certain fundamental changes have taken place in the sphere of corporate governance: the rotation of directors has become much more common and the number of enterprises with outsider's stakes higher, while the influence of regional authorities has weakened. Thus, although the orientation toward a regional patronage of bankruptcy procedures is still maintained, and they are applied by CEOs in order to preserve their control, it is, nevertheless, giving way to property redistribution between different business groups.

The initiation of bankruptcy procedures has become a low-cost alternative to a hostile takeover ${ }^{71}$. Corporate law provides numerous instruments for protection against takeovers, whereas the law on insolvency creates ideal conditions for an "aggressor", which almost entirely exclude the possibility of a failure. Sometimes the views of some large business groups as to the economic role of bankruptcy are expressed by individual experts very explicitly and astonishingly frankly ${ }^{72}$. While quite justly pointing to the problems associated with Russia's entry into the WTO and the need for increasing economic concentration in some

\footnotetext{
${ }^{71}$ Radygin A. Sobstvennost' i integratsionnye protsessy v korporativnom sektore (Property and integration processes in the corporate sector). - Voprosy ekonomiki, 2001, No. 5.

${ }^{72}$ Tsygichko A. Innovatsionnye pigmei, chlenstvo v VTO i zakonodatel'stvo o bankrotstve (Innovational pygmies, membership in the WTO and bankruptcy legislation). See www.rsppr.ru, 2001.
} 
sectors in order to ensure their competitive capacities on the international markets, the experts come to a rather disputable conclusion that the existing institution of insolvency is on the whole quite adequate, since the State has the right to effectuate "low-cost property redistribution in order to improve the efficiency of societal production", while the largest enterprises and holdings have real opportunities "to rapidly and cheaply expand their businesses..."

On the whole, it can be stated that the institution of bankruptcy in Russia, as it has emerged so far, cannot be regarded as a stable and efficient corporate governance mechanism aimed at rehabilitating the management and finances of companies - an overwhelming majority of private creditors are not in a hurry to apply the legal schemes offered by the Law on bankruptcy, preferring "private enforcement".

\section{The specific features of bankruptcies in certain groups of debtors}

In order to lower the risks associated with applying bankruptcy procedures to enterprises belonging to the category of subjects of natural monopolies, in mid-1999 the law "On the peculiarities of insolvency (bankruptcy) of subjects of natural monopolies in the fuel-and-energy sector" was enacted ${ }^{73}$. In fact, this law builds upon the principle of unpayability. The introduction of an entirely new principle for defining insolvency increases the risk of debts being artificially "knocked off" or accumulated at the enterprises within natural monopolies by those enterprises in respect to which the old conditions for determining insolvency are applied.

\footnotetext{
${ }^{73}$ It would be appropriate to comment here that even at the level of declarations, the state policy in respect to the development of the institution of bankruptcy was very controversial. For example, in 1999, in order to receive credits from the IMF, the RF Government, in its «Letter concerning development policy for the purposes of the third loan for restructuring of the economy", declared its intention to intensify bankruptcy processes, in particular, by lifting the moratoria on bankruptcies of enterprises initiated by the State, by expanding the possibilities for their liquidation, and by eliminating the practice of submitting draft laws concerning the specific features of insolvency in certain sectors. However, in the same year, the RF Government did submit two draft laws designed to regulate the specific features of insolvency in the sphere of natural monopolies and in the military establishment, and resulting was the enactment, on 24 June 1999, of the Law "On the peculiarities of insolvency (bankruptcy) of subjects of natural monopolies in the fuel-andenergy sector".
} 
According to some eminent experts, the practice of applying the norms established for the bankruptcy of enterprises forming company towns deserves a rather positive estimation ${ }^{74}$. The bankruptcy procedures designed for this category of debtors envisage the participation of an appropriate local self-government body; in response to a petition filed by the bodies of executive authority, an arbitrage court, contrary to the decision of a creditors' meeting, may impose external administration (when there is suretyship issued by such bodies in respect to the debtor's liabilities); in exceptional cases, the period of external administration may be extended for up to 10 years. At the same time, experts have noted the imperfection of the procedure for granting suretyships by the bodies of executive authority. In some instances, such suretyships have the form of "soft guarantees", are granted without any conditions concerning the status of local budgets or an estimation of the financial possibilities for executing the suretyships, and are limited by the local leaders' tenure of office.

\section{Basic insolvency procedures}

The 2nd Law on bankruptcy, by way of augmenting the provisions established by the previous law, introduced a new procedure of supervision. This procedure was aimed at ensuring the safety of a debtor's property during the period when the creditors were being identified, the register of the creditors' claims compiled, and the debtor subjected to financial analysis. The essence of supervision was that the debtor's CEOs continued to execute their powers; however, certain transactions could be effectuated by them only with the consent of a temporary administrator. Besides, if a debtor's director was not implementing appropriate measures to safeguard its property or prevents the bankruptcy commissioner from adequately executing his duties, the arbitrage court could dismiss the director from his post.

At the same time, the supervision procedure was not described precisely enough; the period of time established for this procedure was too

\footnotetext{
${ }^{74}$ In "The Law on bankruptcy" (Article 132), the enterprises forming company towns are understood as enterprises whereat the employees (including their families) constitute no less than one-half of the total population of a given settlement. Besides, the provisions of the Law on bankruptcy concerning enterprises forming company towns are applied also to other enterprises whereat the number of employees is over 5,000 .
} 
short; while the register of the creditors' claims was being prepared, manipulations were possible in respect to the recognition of certain creditors; the amounts of debts to those creditors could be distorted. During the supervision procedure, creditors had the right to submit their claims to the debtor. The bankruptcy commissioner was responsible for identifying the debtor's creditors and for sending to them notifications concerning their right to submit their claims to the creditor. The practice of implementing this law has shown that the bankruptcy commissioner was unable to identify all of the creditors; in particular, this is true in respect to depersonalized creditors (bills, securities to bearer).

During the supervision procedure, neither the debtor's administration nor the temporary administrator were protected securely enough from one another's arbitrary actions ${ }^{75}$. In accordance with the 2nd Law on bankruptcy, the register was to be kept by the bankruptcy commissioner alone. It sometimes so happened that the register of creditors was changed several times prior to a creditor's meeting.

External administration has been established as one of the bankruptcy procedures by the previous law as well, however the new law expanded the debtor's capacities for regaining solvency. When external administration was introduced, the powers of the debtor's director were terminated, and a moratorium was imposed on satisfying the creditors' claims (excepting those obligations, the time for the fulfilling of which came after the imposition of external administration).

During the period of external administration, creditors had the right to participate in the management of the debtor. Creditors were granted the right to approve the external administration plan, coordinate big transactions implemented by the debtor, as well as related parties' transactions. In fact, during the procedure of external administration, the debtor's administrative bodies were partly substituted for by the bankruptcy commissioner, creditors' meeting and creditors' committee. The debtor's administrative bodies were dismissed from the process of decision-making concerning the debtor's property, as well as from the reorganization (rehabilitation) of its business. The actual result of implementing such a concept of external administration quite often became an uncontrolled withdrawal of the debtor's assets. In practice,

\footnotetext{
${ }^{75}$ Nabliudeniie - novaia protsedura v zakone o bankrotstve. (Supervision - a new procedure in the law on bankruptcy). - Rynok tsennykh bumag, No. 12. 1999.
} 
quite frequently it happened so that during external administration all liquid property was sold, and the organization itself thereafter became non-viable. There were instances when during external administration decisions were made regarding an issue of additional shares, which resulted in property redistribution.

Many disputes and questions were given rise to by the regime involving the State's participation in bankruptcy procedures, especially within the framework of external administration. In principle, it is the State that ought to have represented public interests not only in respect to mandatory payments but also to the reorganization or rehabilitation of large and socially relevant enterprises. However, the State in the part concerning the recovery of tax debts and other mandatory payments had no right of vote at a creditors' meeting in respect to most of the key issues - for example, regarding the approval of an enterprise's external administration plan. As a result, in some instances the State, possessing a high amount of tax claims, found itself, alongside other creditors, without any satisfaction, since the property complex had been sold under a direct contract at an underestimated price to one of the creditors.

The exclusion of the State from participating in bankruptcy procedures has been explained by the specific nature of the claims relating to taxes and other mandatory payments, however the degree of this exclusion from bankruptcy procedures was obviously too high.

During bankruptcy proceedings, creditors had the right to participate in managing the debtor's property (disposing of the mass of the bankrupt's estate). The sale of the debtor's property was effectuated under the creditors' and the court's control. The norms establishing the procedure for disposing of a debtor's property and the control over the sale of this property by the receiver were on the whole designed to protect creditor's rights. At the same time, the sale of the debtor's property was not public to a sufficient degree. As has been shown by practice, receivers were striving to create conditions under which a debtor's most liquid property was to be sold to organizations related to those receivers.

It would have been wrong to affirm that the 2nd Law on bankruptcy as such offered no mechanisms for maintaining an enterprise as a going concern. One of attractive available methods was an amicable settlement. However, the State was excluded from the number of potential 
participants in such an agreement due to the tax-oriented character of its claims (Article 120 of the Law on bankruptcy). As a result, the interest of other creditors in making such a settlement was dramatically diminished.

Within the framework of the measures envisaged by the 2nd Law on bankruptcy in order to prevent bankruptcy, pre-trial reorganization ${ }^{76}$ may be noted, consisting in financial support to the debtor from aside, including from the owner of the debtor's property and the debtor's founders (or participants) (Article 27 of the Law on bankruptcy). In the course of pre-trial reorganization, it was possible for the debtor or for other persons to take upon themselves liabilities to the benefit of the persons who had provided the financial support. Thus, there did exist certain possibilities for the State to prevent bankruptcy of especially relevant enterprises, but because of shortage of budget resources this method of bankruptcy prevention could be applied only in singular cases, when all other means had failed. The abovesaid does not mean that the State, when appropriate resources were available, could implement pre-trial reorganization whenever necessary. In accordance with Item 3 of Article 27, the terms for pre-trial reorganization being implemented at the expense of the federal budget and state off-budget funds should have been established by the laws on the federal budget and the budgets of state off-budget funds.

The third phase (from 2002 onward)

The most important constructive criticism of the Russian institution of insolvency in recent years has been focused on the practices of bankruptcy of large, economically and socially relevant enterprises, as well as on the expansion of the scope of applying bankruptcy procedures for dishonest purposes and the violation of the interests of the State as a creditor and owner.

In the second half of the year 2001, the preconditions necessary for fundamental reform of the institution of (or legislation on) insolvency emerged. The dominant position was thus given to the standpoint oriented not so much to making amendments to the 2nd Law on bank-

\footnotetext{
${ }^{76}$ Teliukina M. Osobennosti novogo zakonodatelstva o nesostoiatel'nosti (bankrotstve) (The peculiarities of new legislation on insolvency (bankruptcy). - Zakonodatel'stvo (Legislation), No. 5, 1999.
} 
ruptcy, but rather to adopting its new version (or novellization ${ }^{77}$ ). At the governmental level, the following issues in the sphere of insolvency (bankruptcy) were stated as the most vital ones:

- violation of the debtor's rights and those of the debtor's founders (initiation of bankruptcy procedures on the basis of fake documentation; on the grounds of a negligible amount of debt, without granting to the debtor any opportunities for repayment; no opportunities for the debtor's founders to rehabilitate their enterprise under the creditors' control after the proceedings in bankruptcy have already been initiated);

- violation of the State's rights as a tax creditor;

- withdrawal of the debtor's assets in the interests of a specific group of creditors as part of the procedures of external administration and bankruptcy proceedings; a common practice of applying premeditated bankruptcy as an instrument for an uncivilized property takeover;

- non-transparency and inadequate regulation of bankruptcy procedures, which make it possible for bankruptcy commissioners and other participants in bankruptcy proceedings to take advantage of this inadequacy; the lack of efficient mechanisms for bringing to responsibility dishonest and inefficient bankruptcy commissioners;

- unjustified specific features established for bankruptcy of enterprises belonging to the fuel-and-energy complex, while no specific features of bankruptcy in the military-industrial complex and natural monopolies outside the fuel-and-energy complex were consolidated in legislation.

The problems listed above provided the grounds for fundamental reforming of the institution of (or legislation on) bankruptcy. In late 2001, the new draft law "On insolvency (bankruptcy)" was submitted to the State Duma, having been developed by the Ministry for Economic Development and Trade. The consideration of the new draft law on insolvency by the RF Federal Assembly was a complicated process, during which more than 3000 amendments were discussed. After lengthy discussions of the draft by the Federal Assembly, the new (third) Law "On

\footnotetext{
${ }^{77}$ V. Vitrianskii. Puti sovershenstvovaniia zakonodatelstva o bankrotstve. (Ways for improving bankruptcy legislation). - Vestnik Vysshego Arbitrazhnogo Suda Rossiiskoi Federatsii (The herald of the Supreme Arbitrage Court of the Russian Federation No. 3, 2001.
} 
insolvency (bankruptcy)" was enacted in October 2002. This Law contains many new provisions, which have the potential for a cardinal transformation of the entire existing bankruptcy practice.

During the discussion of the draft law's provisions, all the parties involved recognized the importance of reforming the following areas of insolvency regulation:

- $\quad$ strengthening the protection of the rights of honest owners;

- optimizing the methods for protecting creditors' interests;

- increasing the State's role in bankruptcy procedures;

- strengthening the protection of the participants in bankruptcy procedures from dishonest actions of third parties;

- increasing the responsibility and improving the qualification of bankruptcy commissioners.

However, the notions as to the possible ways for such reforming turned out to be quite different in some instances.

Firstly, the Ministry for Economic Development and Trade proceeded from the need to remove excessive administrative barriers imposed onto bankruptcy commissioners; to expand the possibilities for self-regulation in this sphere; to develop a system for insuring the responsibility of bankruptcy commissioners. This standpoint was strongly opposed by the Federal Service for Financial Rehabilitation and Bankruptcy (FSFRB), which was arguing in favor of the necessity to maintain and further strengthen the state control over the activity of bankruptcy commissioners.

Secondly, the FSFRB suggested that, in order to restrict the violations in respect to initiating bankruptcy procedures, it should be established that the proceedings could be initiated only if a creditor's claim is confirmed by a court decision that has entered into legal force. For its part, the Ministry for Economic Development and Trade declared that such a change would result in limited rights of small-sized creditors.

Thirdly, the FSFRB and the Ministry for Economic Development and Trade, having recognized the danger associated with bankruptcy of organizations that are strategically significant in terms of national security, differed in their opinions as to how to effectuate the rules determining the specific features of regulating the insolvency of this debtor category. 
Fourthly, the Ministry for Economic Development and Trade suggested that, as one of rehabilitative procedures, an additional issue of the debtor's shares be established ${ }^{78}$. The basic argument against this measure on the part of the FSFRB was that this would result in a new spiral of property redistribution through bankruptcy procedures.

Finally, there were difficulties in respect to the State's participation in bankruptcy procedures in the part of its claims in respect to mandatory payments, because resulting from lengthy arguments was the following decision: the State was granted rights equal to those of other creditors; however, at the same time it had the same priority for satisfying its claims as bankruptcy creditors. This suggestion, no doubt, will give rise to numerous violations, e.g., unpredictable terms for repaying debts to the State, as well as more intense struggle of private structures for making use of the administrative resource.

\section{The main innovations introduced in the $3^{\text {rd }}$ Law on bankruptcy}

By Regulation of the RF Government of 24 December 2001 No. 1696-r, the new draft Law "On insolvency (bankruptcy)" was submitted to the State Duma, elaborated by the Ministry for Economic Development and Trade of Russia. This draft law, as compared to the then existing law, contained a series of significant changes in the sphere of legislative regulation of bankruptcy procedures. According to the results of an interdepartmental coordination, in accordance with the draft law submitted by the RF Government to the State Duma, it was suggested that legislation on insolvency (bankruptcy) be reformed in the following main areas:

\footnotetext{
${ }^{78}$ In principle, this mechanism is being applied in actual practice, and in some cases creditors receive shares in a newly created enterprise (which has received debt-free assets of a debtor enterprise), while in others they receive an additional issue of shares of a debtor enterprise. However, such mechanisms must be determined in sufficient detail in the law on bankruptcy. In order to lower the risk of a premeditated of fictitious bankruptcy aimed at property redistribution, it seems important, on the one hand, to envisage for shareholders an exclusive right to purchase the new shares being issued, and on the other, to establish the possibility to petition to the arbitrage court that a debtor be recognized as bankrupt only on the condition that its creditor has exhausted all other means of debt recovery. Besides, it will be necessary to envisage norms against the possibility of dispersing the State's share in a debtor enterprise's share capital. The main problem is that the State, due to its specific features as a legal subject, cannot take advantage in an operative manner of its preferred right (as a shareholder) to purchase additional shares.
} 
1. Optimization of the rights and methods for protecting creditor's lawful interests

In order to protect the interests of the State as a tax creditor and to grant equal rights to creditors in bankruptcy and the State as a creditor, it was suggested that an empowered federal agency be granted the right of vote in bankruptcy procedures, with a simultaneous placing of the claims concerning mandatory payments in the same category as other commercial creditors. Previously, the State as a creditor was a preferred creditor in bankruptcy proceedings, that is, its tax claims were given priority over the claims of commercial creditors; however, the State, as a tax creditor, had no right of vote at creditors' meetings, excepting at the first meeting.

It was suggested that creditors secured by a pledge be granted a preferred right to the proceeds from the sale of the object of the pledge, as well as the right to veto such a sale. In this connection, the rest of the claims (in excess of the amount of the pledge) of such creditors were to be satisfied in the ordinary procedure, on equal terms with the other creditors.

The draft law established the possibility of settlement before time with creditors in the course of external administration. The execution of the debtor's obligations by a third party (or parties) is also possible. Previously, settlements before time were possible only during the supervision procedure.

2. Expansion and protection of the rights of a debtor's honest owners, including the State as an owner and shareholder

In the draft law, it was suggested that a new reorganization procedure be introduced - that of financial rehabilitation, designed to make it possible for a debtor's founders (or participants), under certain conditions, to keep their control over the enterprise's destiny even during initiated proceedings in bankruptcy.

In order to eliminate the possibilities for law abuse on the part of dishonest creditors, the procedure for initiating bankruptcy was improved. The observation procedure was to be initiated on the basis of a creditor's or an empowered agency's petition that a debtor be declared bankrupt only after their claims had been verified in the course of a special court session. For the proceedings in bankruptcy to be initiated, the claims to the debtor were to be taken into consideration and were to 
be confirmed by a court decision that had entered into legal force, or by a document confirming the arrears of mandatory payments, or by another document of execution, as well as the claims recognized by the debtor no less than one month prior to the date of submitting the petition in bankruptcy.

The draft law envisaged the possibility for representatives of a debtor's founders (or participants) to participate in the proceedings in bankruptcy. The representatives of the debtor's founders were granted all the rights established by arbitrage procedural legislation for persons participating in the proceedings (e.g., to know the results of the debtor's property estimation made by a bankruptcy commissioner). The debtor's participants (or shareholders) were to have the right to be acquainted with the information concerning the proceedings' development, as well as the right to appeal against certain decisions and actions of the bankruptcy commissioner and creditors.

The mechanisms for maintaining a debtor's business have been expanded, in particular, by adding the possibility for returning to external administration from the proceedings in bankruptcy when there exists a real opportunity for restoring solvency; for an additional issue of shares in the course of external administration, on the condition that there was the debtor's owner's consent thereto.

3. Changes in the status of and the procedures for regulating the activity of a bankruptcy commissioner

One of the main goals of the draft law was to establish efficient supervision over the activity of bankruptcy commissioners, through the abolition of the licensing of their activity.

In order to maintain supervision over the activity of bankruptcy commissioners, it was suggested that the protection by the court of justice of the rights of interested persons be strengthened, the supervision effectuated by the court of justice be augmented by professional public control (on the part of self-regulating organizations of bankruptcy commissioners). Due to the absence of uniform legislation on selfregulating organizations, one of the goals of bankruptcy legislation was to establish legal prerequisites for the creation and development of self-regulating organizations (SRO) of bankruptcy commissioners. The SRO's main tasks were to become those of developing the standards for their activity, dealing with complaints and appeals of third parties 
concerning the activity of bankruptcy commissioners, as well as granting financial guarantees to creditors.

It was proposed to replace the administrative barriers in the way of entering the profession of a commissioner by exigent professional requirements, thereby promoting the professional development of bankruptcy commissioners. Besides, it was suggested that the financial responsibility of bankruptcy commissioners be established through their insurance.

4.Improvement of state regulation of bankruptcy procedures

In order to ensure equal rights of the State and creditors in bankruptcy, the draft law envisaged that the State as a mandatory payment creditor be granted the right of vote equal to that granted to creditors in bankruptcy, as well as equal priority for satisfying their claims in bankruptcy proceedings.

The draft law envisaged that the rights of the State as a property owner be expanded. The representative of a debtor's property owner (the debtor being a unitary enterprise), as well as the representative of a debtor's founders (or participants) (the debtor being a juridical person), were to be persons participating in the proceedings in bankruptcy, with the right to appeal against the actions of a bankruptcy commissioner, the decisions of the creditors' meeting and the creditors' committee, the decisions of an arbitrage court concerning the imposition of external administration and management in bankruptcy, etc.

Besides, in order to eliminate the violations on the part of bodies of executive authority, the procedure of granting state guarantees was improved. In order to issue a suretyship, the presence of adequate resources in the corresponding budgets was necessary, as well as the decision to this effect made by an appropriate body of legislative authority.

5. Protection of honest participants in bankruptcy procedures from dishonest actions committed by other parties

Among other mechanisms designed to protect the participants in the process from dishonest actions committed by other parties, the following innovations were envisaged:

- it became impossible to initiate, against the debtor, new proceedings in bankruptcy within three months after the moment of the effectuation of an amicable settlement; 
- it became possible to appeal against the verdicts issued during bankruptcy procedures concerning the results of settling the disputes between the persons participating in the proceedings;

- $\quad$ the procedure for selling the debtor's property was improved, and mandatory public bidding in respect of its sale was established, in the event the balance-sheet value of this property, confirmed by an independent expert, was in excess of 1 million roubles.

6. Establishing the necessary specific features of bankruptcy for certain debtor categories in a single law

The draft law envisaged certain specific features of bankruptcy for organizations belonging to the defense industry and for subjects of natural monopolies. In particular, it was proposed, in respect to organizations belonging to the defense industry, to establish the right for the State to suspend the sale of their property for a period of up to 3 months, in order to develop proposals concerning the restoration of an organization's solvency, including a transition into the procedure of financial rehabilitation.

It is not feasible to establish specific features of bankruptcy for organizations belonging to other branches, because their introduction, as shown by practice, results in an unjustified withdrawal of enterprises belonging to certain branches from the sphere of the application of bankruptcy procedures, which is contrary to the principles of civil law.

The discussion of the new draft law on insolvency in the RF Federal Assembly was rather difficult ${ }^{79}$, for more than 3000 amendments were under consideration. As the most important ones, experts ${ }^{80}$ note the following provisions of the new (third) Law on bankruptcy:

\footnotetext{
${ }^{79}$ The draft law was approved by the State Duma in the first reading on 6 March 2002. When preparing a new version of the draft law for the second reading in the State Duma, more than 3,500 amendments were discussed. After three and a half months of deliberations, on 20 June 2002, the draft law was approved in the second reading, and in less than two weeks thereafter, on 1 July 2002, in the third reading. Finally, on 10 July, the Council of the Federation approved the Law's new version. However, on 6 August is became known that the RF President had rejected the new version of the Law "On insolvency (bankruptcy)". After that, the necessary changes were introduced in the draft law, and it was adopted by the State Duma on 27 September in three readings during one session; the Council of the Federation approved it on 16 October, and on 26 October 2002 it was signed by the RF President.

${ }^{80}$ See, e.g., Skliarova I. Prezident nastaivaet na maksimal'nom usilenii roli gosudarstva v protsedure bankrotstva (The President insists on maximum strengthening of the State's
} 


\section{Lower risk of law abuse on the part of creditors.}

The Law envisages that the initiation of a bankruptcy procedure on a creditor's petition can be possible only after the latter has produced a writ of execution stating that he has made an attempt to have the debts repaid within the framework of execution proceedings, and that all the attempts of a bailiff to recover the debt within 30 days from the moment of a court decision as to the debt recovery have failed, and only the bankruptcy procedure in respect to the debtor remains as the last resort for the creditor to recover the money loaned.

2. Granting equal rights to the State and creditors in bankruptcy; consolidating the State's claims.

The Law equalized the State in its rights with the other creditors in bankruptcy. Now the State, through its empowered agency, has been granted the right of vote at all creditors' meetings, while the State's claims are given the same priority as the claims of creditors in bankruptcy.

3. Expanding the mechanisms for protecting the rights of honest owners.

Now, the owners of a debtor enterprise have become participants in the bankruptcy procedure. The Law establishes the right for the representative of the debtor's owners to repeal in the court the creditors' claims, as well as the right for the debtor, the debtor's owners and any third parties, to terminate, with the bankruptcy commissioner's consent, the bankruptcy procedure at any stage, by repaying the enterprise's debts.

The Law has established a new reorganization procedure - financial rehabilitation, designed to make it possible for a debtor's founders (or participants), under certain conditions, to keep their control over the enterprise's destiny, even during initiated proceedings in bankruptcy. The mechanisms for preserving a debtor's business have been expanded, in particular, by the possibility for returning to external administration from the proceedings in bankruptcy when there exists a real opportunity for restoring solvency, and for an additional issue of shares

role in bankruptcy procedures). See www.bpi.ru Dmitrii Arefiev. O Federal'nom zakone "O nesostoiatel'nosti (bankrotstve) (On the Federal Law "On insolvency (bankruptcy)" (new version). See www.bpi.ru. 
in the course of external administration, on the condition that the debtor's owner have given their consent thereto.

4. Protection of honest participants in bankruptcy procedures from dishonest actions committed by other parties

The following innovations are envisaged:

- the impossibility to initiate new proceedings in bankruptcy against a debtor during the three-month period after the moment of effectuating an amicable settlement;

- the possibility to repeal the verdicts issued during bankruptcy procedures concerning the results of settling the disputes between the persons participating in the proceedings;

- the procedure for selling the debtor's property was improved, and mandatory public bidding in respect of its sale was established, in the event the balance-sheet value of this property, confirmed by an independent expert, is in excess of a certain threshold level.

5. Higher efficiency of the control over the activity of bankruptcy commissioners

One of the main goals of the draft law was to introduce efficient supervision over the activity of bankruptcy commissioners, due to the abolition of licensing their activity. The whole system of ensuring responsibility and supervision over the activity of bankruptcy commissioners has undergone a fundamental change. The functions of supervising the activity of bankruptcy commissioners were transferred from the State, represented by the FSFRB, to non-commercial selfregulating organizations (SRO). The Law grants to the SRO the right to apply to their members disciplinary sanctions, the most serious being the expulsion from the membership in a SRO, as well as petitioning to the arbitrage court that their members be dismissed from participating in bankruptcy procedures as bankruptcy commissioners.

Income qualification has been established for bankruptcy commissioners - a certain amount of money, to be transferred by each bankruptcy commissioner as a lump sum, when entering a SRO, to that organization's compensation fund. The Law established mandatory insurance of the civil responsibility of bankruptcy commissioners by insurance organizations accredited by a SRO.

6. Establishing the necessary specific features of bankruptcy for certain debtor categories in a single law 
The Law envisages certain specific features of bankruptcy for organizations belonging to the defense industry and subjects of natural monopolies. The Law, having abolished the previously existing (in respect to subjects of natural monopolies) principle of unpayability, established no special insolvency criterion for organizations of the military-industrial complex, subjects of natural monopolies and other organizations of high socio-economic and strategic significance. Thus, in respect to the latter, the same insolvency criterion as for all the other categories will be applied, based on the principle of insolvency. Its specificity consists in external indicia of insolvency: in order to initiate proceedings in bankruptcy against the abovementioned organizations, it is sufficient to have debts in the amount of 500,000 roubles, with the delay in repayment of 6 months. Besides, in respect to strategic enterprises it was established that the State has the right to suspend the sale of their property for a certain period of time, in order to develop proposals concerning the restoration of an organization's solvency, including a transition into the procedure of financial rehabilitation.

7. Restrictions against of bankruptcy procedures being too frequently applied for the liquidation of absent debtors

The Law has established that bankruptcy procedures be applied to absent debtors only when appropriate funds are available in the budget.

\subsection{A general estimation of the provisions of the $3^{\text {rd }}$ Law on bankruptcy}

When estimating the provisions contained in the $3^{\text {rd }}$ Law on bankruptcy, the following comments appear noteworthy:

1. On the whole, the provisions of the new law on insolvency stipulating that the State, in the part concerning the requirements in respect to mandatory payments, acquires voting rights equal to those of creditors in bankruptcy, but at the same time has the same priority as they do (third priority) regarding the satisfaction of their claims, appear to be reasonable. Besides, the State in the part concerning the claims in respect to mandatory payments, now can participate in an amicable settlement. However, this approach also has some limitations.

Firstly, without a considerable expansion of the institution of the State's representatives in bankruptcy, there is a much higher risk of corruption growth, due to "trading" the State's votes during the deci- 
sion-making process at creditors' meetings; the risk of a growing activity of local authorities in respect to covert nationalization and property redistribution for the benefit of third parties. It seems necessary, when the State is participating in bankruptcy procedures involving large, socially and economically important enterprises, to envisage the creation of Boards of Authorized Representatives of the State in order to guarantee a balanced representation of various interests of the State.

Secondly, the State's direct participation in an amicable settlement can considerably increase the risk of unequal approaches to different enterprises. It is necessary to legislatively determine (at least the framework for) the conditions on which the State can agree to an amicable settlement.

2. Certain norms contained in the new Law on bankruptcy, in the part dealing with the appointment and activity of bankruptcy commissioners, appear to be rather controversial. In particular, in accordance with the Law, it is mandatory that a bankruptcy commissioner be a member of one of the existing self-regulating organizations. This stipulation in the Law, in its essence, contradicts the RF Constitution, wherein Article 30 states: "Everyone shall have the right to association, including the right to create trade unions in order to protect one's interests. The freedom of public associations activities shall be guaranteed". Also, "No one may be coerced into joining any association or into membership thereof".

In should also be noted that in accordance with the RF Civil Code, one of the fundamentals of civil legislation is the principle that citizens (physical persons) and juridical persons acquire and executte their civil rights by their own will and in their own interest. They are free in establishing their rights and duties on the basis of a contract and in determining any conditions of a contract which are not contrary to legislation. In this connection, it is clearly stated in Article 1 of the RF Civil Code that civil rights may be limited only in the instances specified in this Article, namely:

- the defense of the constitutional system's fundamental principles;

- the defense of morality;

- the defense of public health;

- the defense of the rights and legal interests of other persons;

- to ensure the defense of the country and the security of the state. 
The bankruptcy commissioners' mandatory membership in SRO has no connection whatsoever to either of the abovementioned conditions.

It should be noted that the issue of mandatory membership in selfregulating organizations (and not only for bankruptcy commissioners, but, e.g., for professional participants in the securities market, etc.) is presently the subject of hot disputes. Many experts, who argue that mandatory membership in SRO is legal, are referring to Ruling of the RF Constitutional Court of 28 January 1997 No. 2- ${ }^{81}$ and Ruling of the RF Constitutional Court of 19 May 1998 No. 15- $\mathrm{P}^{82}$. In particular, as follows from the Ruling of the RF Constitutional Court on the case dealing with the verification of the constitutionality of certain provisions of Articles 2, $12,17,24$ and 34 of the fundamental principles of RF legislation on the notariat, "it is especially due to the public purpose of notarial chambers that for their organization the principle of voluntary participation, characteristic of the membership in other associations, which are created for the purpose of satisfying material and other non-material requirements of citizens, exclusively on the basis of the unity of their interests, in unacceptable" (Article 30 of the Constitution of the Russian Federation, Article 117 of the Civil Code of the Russian Federation, Part 1 of Article 3 of the Federal Law "On public associations").

The mandatory membership in a notarial chamber for notaries engaged in private practice, as the condition for practicing the said profession, is contrary neither to the constitutional principle of equality, nor to the constitutional rights of free associations and free choice of activity or professions (Articles 19, 30 and 37 of the Constitution of the Russian Federation), since the State has no right to establish for all the citizens, who are willing to pursue a public (notarial) activity, any mandatory conditions for being appointed to a post and for occupying a post.

From the abovesaid, it follows that, in accordance with the standpoint of the Constitutional Court, the establishing of mandatory membership in self-regulating organizations can be possible in those instances when a certain activity, the pursuance of which is made de-

\footnotetext{
${ }^{81}$ Ruling of the RF Constitutional Court on the case dealing with the verification of the constitutionality of Part Four of Article 47 of the Criminal Procedure Code of the RSFSR, in connection with the complaints of citizens B.V. Antipov, P.L. Gitis and S.V. Abramov.

${ }^{82}$ Ruling of the RF Constitutional Court on the case dealing with the verification of the constitutionality of certain provisions of Articles 2, 12, 17, 24 and 34 of the fundamental principles of RF legislation on the notariat.
} 
pendent on membership in a SRO, has a publicly legal status and is associated with the performance of certain functions on behalf of the State, which entails the necessity to organize an efficient control over the activity of the specialists engaged in the publicly legal activity. Nevertheless, as follows from Article 2 of the Law "On bankruptcy", a bankruptcy commissioner is a RF citizen, appointed by an arbitrage court to effectuate bankruptcy procedures, as well as to implement other powers established by the Law "On bankruptcy". In this connection, the effectuation of bankruptcy procedures cannot be recognized as publicly legal activity, since such an activity means primarily an activity on behalf of the State.

In our opinion, the most correct is the standpoint in accordance with which the membership of bankruptcy commissioners in self-regulating organizations must be voluntary, because it is fully compatible with the fundamental law of the RF - the RF Constitution, as well as with civil legislation of the RF.

3. One of the fundamentally new provisions in the Law "On bankruptcy" is the established wider range of persons capable of participating in the arbitrage proceedings in bankruptcy. Now, alongside the representatives of the debtor's employees and the representative of the owner of the debtor's property - a unitary enterprise, the representatives of the debtor's founders (or participants) can also participate in the arbitrage proceedings, which is undoubtedly a positive development, since the said persons have an interest in protecting the debtor's rights, and their participation actually is a guarantee of the protection of the debtor's rights and interests.

Nevertheless, as justly notes V. Vitrianskii ${ }^{83}$, "one cannot but be alerted by the fact that the Law on bankruptcy contains a number of provisions concerning the so-called third parties, who, being neither the persons participating in a bankruptcy case, nor the persons participating in the arbitrage proceedings in bankruptcy, are sometimes invested with the powers similar to those granted to the founders (or participants) of economic societies and partnerships, as well as to the owner of a debtor's property - a unitary enterprise". It is true that, although according to Article 35 of the Law "On bankruptcy", "other persons, in

\footnotetext{
${ }^{83}$ Novoe v pravovom regulirovanii nesostoiatel'nosti (bankrotstva) (Innovations in legal regulation of insolvency (bankruptcy). - Khoziaistvo i pravo, No. 1, 2003.
} 
the instances envisaged by the RF Arbitrage Procedural Code", may participate in the arbitrage proceedings in bankruptcy, in many cases they are granted too many powers. For example, as follows from Article 76 of the Law, that in the course of supervision a third party (or third partiers), in the procedure established by the law, has the right to address the first creditors' meeting, and in the instances envisaged by the Law "On bankruptcy" - to petition to the arbitrage court that financial rehabilitation be implemented.

Also, as follows from Article. 113 of the Law "On bankruptcy", a third party (or third partiers), at any time prior to the completion of external administration, in order to terminate the proceedings in bankruptcy, has the right to satisfy all the creditors' claims specified in accordance with the register of creditors' claims, or to transfer money to the debtor in an amount sufficient for satisfying all the creditors' claims in accordance with the register of creditors' claims.

The Law also allows that an agreement be concluded between a third party (or third partiers) and the debtor's managerial bodies, empowered in accordance with the constitutive documents to make decisions concerning the implementation of big transactions, as well as concerning other conditions for the transfer of money funds for the fulfillment of the debtor's obligations.

It should be noted that the said norms stipulated in the Law have received a variety of estimations made by different experts.

For example, according to some experts ${ }^{84}$, the said norm has been introduced in the Law as a measure "against the so-called orchestrated bankruptcies".

Nevertheless, V. Vitrianskii believes ${ }^{85}$ that, "by transferring a certain amount of money to satisfy the claims of the debtor's creditors, a third party thus becomes its sole creditor, while the debtor becomes fully dependent on this third party, the only motivation for whose actions (if it is not a charitable organization) can be property redistribution, that is, complete control over the debtor's activity. Therefore, the said provi-

\footnotetext{
${ }^{84}$ Kommentarii k Federal'nomu zakonu "O nesostoiatel'nosti (bankrotstve) (A commentary to the Federal Law "On insolvency (bankruptcy)", ed. by V.V. Zalesskii. - M. Izdatel'stvo g-na Tikhomirova M.Yu., 2003.

${ }^{85}$ Novoe v pravovom regulirovanii nesostoiatel'nosti (bankrotstva) (Innovations in legal regulation of insolvency (bankruptcy). - Khoziaistvo i pravo, No. 1, 2003.
} 
sions in the Law represent nothing else but a legal mechanism for a "takeover" of a debtor's property".

In our opinion, the viewpoint expressed by V. Vitrianskii should be agreed with. Also, in order to further improve bankruptcy legislation, it is advisable to consider the feasibility of establishing a certain limited range of persons empowered for executing the actions described above during the arbitrage proceedings in bankruptcy.

4. The rehabilitation and reorganization procedures envisaged in the 2nd Law on bankruptcy for debtor enterprises have proved to be of a very low efficiency. In this connection it can be mentioned that the new Law on bankruptcy (the third) has both greatly expanded the set of available instruments and improved their "quality" and degree of protection from abuse. However, the following problems deserve to be mentioned.

It should be admitted that the necessity for the State to participate in bankruptcy procedures has significantly distorted the motivations of all the parties involved. Therefore, certain measures should be introduced for regulating the accruals of payments to the budgets and other mandatory payments outside bankruptcy procedures. In this connection, the mechanisms for debt restructuring seem efficient, but the incentives for implementing the restructuring are not equally strong enough for all the shareholders (or owners) of an enterprise. In fact, the decision concerning the implementation of restructuring at an enterprise's level can be blocked by minority shareholders. In this connection, if the State later does initiate a bankruptcy procedure, all the shareholders will be placed under equal conditions. So, it appears important to investigate the feasibility of establishing different rights in bankruptcy procedures for those shareholders who have voted "for" or "against" debt restructuring.

5. In respect to large strategic enterprises, among the measures designed to prevent bankruptcy in accordance with the $2^{\text {nd }}$ Law on bankruptcy, one can single out pre-trial reorganization (Article 27), aimed at providing financial support to the debtor from aside, including from the owner of the debtor's property and from the debtor's founders (or participants). In the course of pre-trial reorganization, the debtor or other persons may take upon themselves certain liabilities for the benefit of those persons who have provided the financial support. It does not fol- 
low herefrom that the State may, when resources are available, at a necessary moment effectuate pre-trial reorganization - the conditions for pre-trial reorganization at the expense of the federal budget and state off-budget funds must be established by the laws on the federal budget and the budgets of state off-budget funds. It should be noted that while the federal budgets were being formed, such expenditures were never envisaged, and so the provisions concerning pre-trial reorganization became non-operatve.

In the new Law on bankruptcy, there are also norms concerning pretrial reorganization (Article 31). The fact that within the framework of the new Law the need for the State to allocate appropriate funds in the federal budget has never been mentioned does not mean, in our opinion, that these funds are not to be preliminarily specified in the budget. Thus, there arise the tasks of estimating the minimum amounts of expenditures to be envisaged in the budgets for pre-trial reorganization and including such expenditures in the draft budget. Besides, a certain limited entity of enterprises should be determined, in respect to which, in case the situation develops unfavorably, the State would be ready to resort to pre-trial rehabilitation, and (importantly) the necessary content of debtors' liabilities to the State in terms of pre-trial reorganization should also be preliminarily specified.

6 . By the $3^{\text {rd }}$ Law on bankruptcy, a new bankruptcy procedure has been introduced - that of financial rehabilitation (Chapter 5, Articles 7692). This procedure may become an important instrument for an enterprise's rehabilitation and reforming under the control of its owners (including the State as a shareholder). At the same time, attention should be paid to the fact that this procedure can be imposed by an arbitrage court without the creditors' consent (Items 2 and 3 of Article 75, Item 1 of Article 80). However, the financial rehabilitation plan and debt redemption schedule prepared by a debtor's owner must be approved by a creditors' meeting. In this connection, it is not quite clear what would happen if a creditors' meeting refuses to approve the financial rehabilitation plan (which can be very probable if the creditors' meeting is opposed to the introduction of this procedure). Also, the issue concerning the compatibility of the provisions of Article 5 (e.g., Items 1 and 2 of Article 77 ) with some of the norms established by corporate legislation (in 
particular, with the provisions of the Federal Law "On joint-stock companies" designed to protect the interests of minority shareholders).

7. The exchange of an enterprise's debts for shares transferred to the creditors during bankruptcy procedures may become one of efficient enough mechanisms for maintaining the activity of large, economically and socially relevant enterprises. The $2^{\text {nd }}$ Law on bankruptcy did not specify the issues concerning additional issues of shares. In principle, this mechanism has been applied in actual practice, and the creditors in some cases received shares in newly created enterprises (to which debt-free assets of the debtor enterprise had been transferred), while in others - the shares of an additional issue of the debtor enterprise.

We should like to note the following elements in the regulation of an additional issue of shares during external administration in accordance with the new $3^{\text {rd }}$ Law on bankruptcy:

- $\quad$ shareholders have a preferred right for purchasing the shares being placed;

- the shares are placed only by a closed subscription;

- the additional shares are to be paid for only by money.

Thus, the situation when the State is one of the shareholders has not received due attention. For one thing, there exist legislative restrictions to "dispersing" the State's share during an additional issue of shares. For another, the State, due to the peculiar features of its status as a legal subject is unable to operatively enough apply its preferred right (as a shareholder) to purchase additional shares - the period established for shareholders to implement their preferred right to purchase shares cannot be longer than 45 days from the date of their placement. As a result, this form of business rehabilitation may not operate efficiently enough in respect to enterprises in the public sector.

8. It appears important to pay attention to one of the provisions concerning the sale of strategic enterprises during the implementation of bankruptcy procedures, which was contained in the RF President's Estimation of the Law's new version: in accordance with Item 8 of Article 195 , the creditors in bankruptcy and their affiliated persons are not allowed to participate in the bidding. We believe that this proposal, while being absolutely correct and reasonable in its idea, in the specific Rus- 
sian situation, in the event of the bankruptcy of a large enterprise, may give rise to some significant problems.

Firstly, under the conditions of well-developed genuine affiliation of financial structures (including through industrial enterprises), a high concentration of financial resources and the presence of many different creditors in the instances of large debtors, the range of potential, financially prosperous buyers may become considerably narrower. This is fraught not only with creditors' losses (and losses suffered by the State, as one of the creditors), if the enterprise is sold at a lower price, but also with a possible transition (when it becomes impossible to sell an enterprise as a whole entity) to the sale of separate assets. Secondly, the detection of affiliated persons, as has been demonstrated by the practical experience of the antimonopoly agencies, is a process that requires much effort, arguments and time. This creates even more fertile grounds for corruption and voluntarism, as well as for scandals arising after the bankruptcy procedures have been completed.

At the same time, if the State does operatively apply its preferred right (under the new Law) during the sale of strategic enterprises, the abovelisted risks will become less important.

9. One of effective forms of preserving a business may become the sale (as a single property complex) of a city-forming organization. The terms of this sale, as stipulated in the $2^{\text {nd }}$ Law (Article 137), were too cumbersome for the buyer, and so this form did not become commonly applied. Therefore, the softer requirements to the buyer in Article 175 of the $3^{\text {rd }}$ Law on bankruptcy (lowered mandatory number of preserved jobs from $70 \%$ to $50 \%$, a specified period for implementing this requirement (three years), more possibilities for changing an enterprise's specialization) will make enterprises forming company towns more attractive in terms of their purchase as a single complex.

At the same time, the formal (non-economic) character of the requirements to the buyer has remained unchanged. Indeed, a dishonest buyer may slightly reduce the personnel's number, while at the same time dramatically lowering the average wage at an enterprise. In fact, this may result only in keeping "hidden unemployment" at the same level as before, or even making it higher. Therefore, it appears necessary to establish also a certain framework for changing the enterprise's 
general payroll fund, at the same time envisaging more opportunities for personnel cuts.

10. In terms of preventing premeditated bankruptcies, implementing reorganization procedures and maintaining the businesses of large socially and economically relevant enterprises, the norms established by the $2^{\text {nd }}$ Law in respect to enterprises forming company towns deserve a positive estimation. The $2^{\text {nd }}$ Law envisages that in the bankruptcy procedures established for this debtor category, a local self-government body is to participate; the arbitrage court, in a petition filed by the bodies of executive authority, may impose external administration, including against a decision to the contrary made by a creditors' meeting (when such bodies issue a suretyship in respect to the debtor's liabilities), and in some cases the period of external administration may be extended for up to ten years; also, on a petition filed by the bodies of executive authority, an enterprise may be sold at a tender, provided that certain conditions are specified.

The new Law on bankruptcy also stipulates the specific features of the bankruptcies of enterprises forming company towns (Articles 168176). However, the innovations in this sphere appear dubious. The "modified" criteria for placing enterprises in the "enterprises forming company towns" category are rather disputable.

Firstly, although the threshold level has been lowered from $50 \%$ to $25 \%{ }^{86}$, at the same time, on the one hand, the families of an enterprise's employees are not taken into consideration, while on the other, the number of those employed at the enterprise is compared not to the total size of population in a given settlement (Item 1 of Article 132 of the $2^{\text {nd }}$ Law on bankruptcy), but to the size of the working population. Thus, the criterion for defining enterprises forming company towns in the draft law on insolvency has been tightened, as compared to the existing regulation.

Secondly, the formal character of defining company-town forming category of enterprises has remained as before. The formal fact that many employees are registered as working at an enterprise does not

\footnotetext{
${ }^{86}$ See Item 1 of Article 169 of the new (third) Law on bankruptcy: "For the purposes of this Federal Law, it is those juridical persons that shall be recognized as enterprises forming company towns, whereat the number of employees constitute no less than twenty-five percent of the total working population of a given settlement".
} 
necessarily mean that it is a large-scale business, while the fact that those employees constitute a considerable percentage in a settlement's total work force is not always an evidence of the enterprise's actual company-town forming role, especially if it has substantial arrears of wages, or these wages are very low. In our opinion, it is more important to apply criteria like the percentage of an enterprise's tax payments in the total taxes collected in a given settlement; an enterprise's dominant position on the commodities market; etc. It should be noted that it is specifically those enterprises which generate a substantial percentage of tax revenues that may become an object for applying bankruptcy procedures with the purpose of property redistribution, because this is a more vivid sign of their financial potential.

11. The $3^{\text {rd }}$ Law on bankruptcy (Article 172) has dramatically reduced the opportunities for reorganizing company-town forming enterprises, because presently financial rehabilitation or external administration can be extended for no longer than one year, and the terms even for this modest prolongation have become tougher. If the $2^{\text {nd }}$ Law (Article 135) allowed that the arbitrage court may extend the period of external administration for up to one year, given a petition to this effect and a prepared financial rehabilitation plan, in accordance with the new law the extention for a similar period is allowed only when there are both a petition to this effect and a suretyship. The main drawback of insolvency regulation in respect to city-forming enterprises within the framework of the $2^{\text {nd }}$ Law was the insufficiently strict procedure for issuing suretyships by bodies of executive authority. In some cases such suretyships are, in fact, "soft guarantees", being granted without any specific terms as to the status of local budgets and the estimation of the financial capacities for implementing the suretyships, and are limited by the local leaders' tenure of office. However, in the new Law this problem has largely been solved.

Company-town forming enterprises probably represent the most difficult object in terms of financial rehabilitation. The inefficiency of such enterprises is due not so much to intrinsic factors (bad administration, outdated equipment, etc.), but to external ones - the region's general economic slump, low effective demand, low level of the local banking system's development, etc. For this reason, it would be unrealistic to expect that the reorganization of an enterprise which forms a company 
town may result in at least a breaking-even level of operation in less that 4 or 5 years. It is not accidental that, according to the arbitrage statistics, in 2000 the period of external administration was extended to 2.5 years for 187 enterprises and to 10 years for 47 enterprises, and in 2001 - for 146 and 31 enterprises, respectively.

\subsection{The formation of a subordinate legal base and regulation of the powers of the bodies of state authority during the period of the new Law being in force}

The adoption of the new Law on bankruptcy, resulting in an important modification of the institution of insolvency, determined the necessity to reconsider the subordinate normative base in this sphere. After the Law's coming into force, various bodies of state authority issued a number of subordinate acts, including the following ones:

- Decree of the RF Government of 30.11.2002, No. 855, "On the empowered and regulating body in bankruptcy cases and bankruptcy procedures" (hereinafter - Decree No. 855);

- Decree of the RF Government of 14.02.2003, No. 100, "On the empowered body in bankruptcy cases and bankruptcy procedures and the regulating body for effectuating the control over self-regulating organizations of bankruptcy commissioners" (hereinafter - Decree No. 100);

- Decision of the Plenum of the RF Supreme Arbitrage Court (SAC) of 08.04.2003 No. 4 "On some issues relating to the enactment of the Federal Law "On insolvency (bankruptcy)";

- Order of the RF Ministry of Justice of 09.04.2003 No. 84 "On approving the Provision on the procedure for keeping a single State Register of the self-regulating organizations of bankruptcy commissioners";

- Decree of the RF Government of 15.04.2003 No. 218 "On the procedure for presenting claims concerning the liabilities to the Russian Federation in bankruptcy cases and bankruptcy procedures" (hereinafter - Decree No. 218);

- Decree of the RF Government of 20.05.2003 No. 295 "On the representative of the owner of a debtor's property - a state unitary en- 
terprise - during the implementation of bankruptcy procedures" (hereinafter - Decree No. 295);

- Decree of the RF Government of 22.05.2003 No. 299 "On approving the general rules for preparing the reports (estimations) of a bankruptcy commissioner";

- Decree of the RF Government of 28.05.2003 No. 308 "On approving the rules for a theoretical examination according to a unified program for preparing bankruptcy commissioners" (hereinafter Decree No. 308);

- Decree of the RF Government of 25.06.2003 No. 365 "On approving the provision concerning the verification of the activity of a selfregulating organization of bankruptcy commissioners by a regulating body";

- Decree of the RF Government of 25.06.2003 No. 366 "On approving the rules for a verification by a self-regulating organization of bankruptcy commissioners of the activity of its members";

- Decree of the RF Government of 25.06.2003 No. 367 "On approving the rules for the conduct of a financial analysis by a bankruptcy commissioner";

- Decree of the RF Government of 09.07.2003 No. 414 "On approving the rules for the conduct of training on the job for the assistants of bankruptcy commissioners";

- Letter of the RF Ministry for Taxes and Levies of 25.07.2003 No. CA-6-04/825 "On some issues concerning the taxation of the incomes of bankruptcy commissioners";

- $\quad$ Order of the RF Ministry of Justice 06.08.2003 No. 189 "On approving the procedure for the operation of boards for organizing a theoretical examination in accordance with a single program for training bankruptcy commissioners";

- Decree of the RF Government of 14.11.2003 No. 688 "On the interdepartmental board for determining the feasibility of filing petitions that debtors be deemed to be bankrupt" (hereinafter - Decree No. 688).

It seems reasonable to discuss briefly the most important acts among those listed above.

In accordance with Decree No. 855, the functions of an empowered body representing in bankruptcy cases and bankruptcy procedures the 
claims concerning mandatory payments and the Russian Federation's claims concerning financial liabilities, as well as the functions of a regulating body effectuating control over the activity of self-regulating organizations of bankruptcy commissioners, were temporarily (for the period of three months, from the moment of coming into force of the new Law on bankruptcy) delegated to the Federal Service for Financial Recovery and Bankruptcy (FSFRB) of Russia.

Decree No. 100, adopted to replace this document, on a permanent basis consolidated to the FSFRB the functions of an empowered body which represents in bankruptcy cases and bankruptcy procedures both the claims concerning mandatory payments and the Russian Federation's claims concerning financial liabilities. As for the functions of a regulating body effectuating control over the activity of self-regulating organizations of bankruptcy commissioners, they, in accordance with Decree No. 100, from 3 March 2003 were to be transferred to the RF Ministry of Justice.

In accordance with Decree No. 295, the powers of a representative of the owner of a debtor's property - a federal state unitary enterprise are executed, during the implementation of bankruptcy procedures, by the Ministry for the Management of State Property of Russia, excepting the instances when by decision of the RF Government the said powers are delegated to another federal body of executive authority or to a juridical or physical person.

Decree No. 308, in addition to approving the rules for a theoretical examination according to a single program for preparing bankruptcy commissioners, delegates to the RF Ministry of Justice the powers to create the boards for organizing and conducting such an examination.

Decree No. 218 deserves special attention. Below we are going to discuss its main provisions in more detail.

1. The Decree establishes that in the event of a non-execution, by a debtor, of the liabilities concerning mandatory payments, or the Russian Federation's claims concerning financial liabilities, in the amount sufficient for initiating bankruptcy procedures, the appropriate bodies of state authority shall submit to the FSFRB of Russia or its territorial agency a notification concerning those debts.

2. The Decree recognizes four debtor categories: 
A - debtors, the amount of whose non-liquid assets exceeds 5 billion roubles, or strategic organizations, or those in respect to which the RF President or the RF Government have issued an order concerning the consideration of the filing against them a petition in bankruptcy;

B - debtors, the amount of whose non-liquid assets is between 1 and 5 billion roubles;

$\mathrm{C}$ - debtors, the amount of whose non-liquid assets is between 300 million and 1 billion roubles;

$\mathrm{D}$ - all the other debtors.

3. The level for making the decision concerning the initiation of bankruptcy procedures is determined in accordance with a debtor category.

The decision concerning the petition to deem a Category A debtor to be bankrupt is made by the RF Government, the Chairman of the RF Government, or, by the latter's commission, by the Deputy Chairman of the RF Government.

The decision concerning the filing of a petition to deem the debtors belonging to Categories $B-D$ to be bankrupt is made, in accordance with the established procedure, by the FSFRB of Russia.

4. The feasibility of petitioning to deem the debtors belonging to Categories A and B to be bankrupt is determined by the Interdepartmental Commission, whose composition is approved by the RF Government. The responsibility for conducting the sessions of this Commission is imposed on the FSFRB of Russia.

The proposals concerning the feasibility (or non-feasibility) of filing a petition in bankruptcy against a Category A debtor, with the protocol of a session of the Interdepartmental Commission, formalized in coordination with the RF Ministry for Economic Development and Trade, are submitted by the FSFRB to the RF Government.

The proposals concerning the feasibility (or non-feasibility) of filing a petition in bankruptcy against a Category B debtor, with the consent of the RF Ministry for Economic Development and Trade, is formalized by order of the FSFRB of Russia. In the event of an absence of such a consent, in the meeting's protocol a substantiated conclusion made by the RF Ministry for Economic Development and Trade is entered, on the basis of which the FSFRB of Russia prepares a report and submits it, with the protocol, to the RF Government. 
5. The feasibility of filing petitions in bankruptcy against debtors belonging to Categories $C$ and $D$ is determined by the interdepartmental meeting, the composition of which is approved by the FSFRB of Russia in coordination with the RF Ministry for Economic Development and Trade.

In respect to debtors belonging to Categories $C$ and $D$, the sessions of the interdepartmental meeting are held, respectively, by interregional-territorial or territorial bodies of the FSFRB of Russia and are formalized by protocols coordinated with the RF subjects' bodies of executive authority or bodies of local self-government at the place of a debtor's registration. In the event of consent, the decision concerning the feasibility (or non-feasibility) of filing a petition in bankruptcy against a debtor is formalized by order of a interregional territorial (or territorial) body of the FSFRB of Russia. In the event of absence of such consent, a substantiated conclusion of a coordinating body is reflected in the protocol, on the basis of which the interregional territorial (or territorial) body of the FSFRB of Russia prepares a report and submits it, with the protocol, to the FSFRB of Russia (or its interregional territorial body), to be considered by a superior interdepartmental commission (or an interdepartmental meeting).

6. In the event of receiving a decision made by the RF Government, the Chairman of the RF Government, or by the Deputy Chairman of the RF Government, concerning the filing of a petition that a debtor be deemed to be bankrupt, or the issuing of an order to this effect, the FSFRB of Russia (or its interregional territorial or territorial body) within a two-week period petitions the court that the debtor be deemed to be bankrupt.

7. The FSFRB of Russia represents, in bankruptcy cases and bankruptcy procedures, the Russian Federation's claims, including the participation in creditors' meetings, the filing of complaints concerning the actions of bankruptcy commissioners, the filing of other claims and petitions, as well as implements other powers envisaged by existing legislation.

8. Prior to participating in a creditors' meeting, the agenda of which contains the issue concerning the choice of a bankruptcy procedure, the FSFRB of Russia requests the opinion of the corresponding body of executive authority of a RF subject and a local self-government body in 
respect to applying bankruptcy procedures and the process of implementing a bankruptcy procedure.

The bodies of executive authority of RF subjects and local selfgovernment bodies may request from the FSFRB of Russia the information concerning the process of implementing bankruptcy procedures. This information must contain the data on the bankruptcy procedure being effectuated against a debtor, on the bankruptcy commissioner nominated by the arbitrage court, on the process of implementing the bankruptcy procedure and on the debtor's financial status.

9. The FSFRB, once in a half-year, informs the RF Ministry for Economic Development and Trade as to the number of bankruptcy procedures on the territory of each RF subject and as to the organizations belonging to each of the economy's branches, and also informs it on the types of the said procedures.

10. The RF Ministry for Economic Development and Trade of Russia, in cooperation with the FSFRB of Russia, annually submits information to the RF Government as to the number of bankruptcy procedures and proposals concerning the implementation of the State policy in the sphere of financial recovery and bankruptcy.

On the whole, the procedure for initiating the proceedings in bankruptcy established by Decree No. 218 was very complicated and bureaucratic; however, the very fact of its normative definition deserved a positive estimation.

Finally, Decree No. 688 envisaged the creation of the Interdepartmental Commission for determining the feasibility of filing petitions in bankruptcy and approved the Provision regarding this Commission.

By the end of 2003, the normative acts then in effect were establishing the following distribution of the powers of the federal bodies of executive authority within the framework of the institution of bankruptcy:

The RF Government:

- makes decisions concerning the filing of petitions that a Category $A$ debtor be deemed to be bankrupt;

- approves the composition of the Interdepartmental Commission; The FSFRB of Russia:

- represents, in bankruptcy cases and bankruptcy procedures, the claims concerning mandatory payments and the Russian Federation's claims concerning financial liabilities; 
- makes, in accordance with the established procedure, the decision concerning the filing of petitions that debtors belonging to Categories $B-D$ be deemed to be bankrupt;

- holds the Interdepartmental Commission's meetings, formalizes, in coordination with the RF Ministry for Economic Development and Trade, the protocol of the Commission's meeting, and in the established instances submits it to the RF Government;

- approves the composition of the interdepartmental meeting in coordination with the RF Ministry for Economic Development and Trade;

- in the established instances petitions the court that a debtor be deemed to be bankrupt;

- performs the functions of an empowered body representing in bankruptcy cases and bankruptcy procedures the claims concerning mandatory payments and the Russian Federation's claims concerning financial liabilities, including the participation in creditors' meetings, filing complaints of the actions of bankruptcy commissioners, and filing claims and petitions, etc.;

- $\quad$ prior to participating in a creditors' meeting, the agenda of which contains the issue concerning the choice of a bankruptcy procedure, requests the opinion of a corresponding body of executive authority of a RF subject and a local self-government body;

- $\quad$ submits to the bodies of executive authority of RF subjects and local self-government bodies, on their request, the information concerning the bankruptcy procedure being applied to a debtor, the bankruptcy commissioner appointed by the arbitrage court, the process of implementing the bankruptcy procedure, and the debtor's financial status;

- jointly with the RF Ministry for Economic Development and Trade, annually submits to the RF Government the information concerning the number of bankruptcy procedures and proposals concerning the implementation of the state policy in the sphere of financial recovery and bankruptcy;

The RF Ministry of Justice:

- $\quad$ performs the functions of a regulating body executing control over the activity of self-regulating organizations of bankruptcy commissioners; 
- implements the powers for forming the boards for organizing and conducting a theoretical examination according to a single program for training bankruptcy commissioners;

The RF Ministry for Economic Development and Trade:

- coordinates the decisions concerning the feasibility (or nonfeasibility) of filing a petition that debtors belonging to Categories $\mathrm{A}$ and $B$ be declared bankrupt;

- jointly with the FSFRB of Russia, annually submits to the RF Government the information concerning the number of bankruptcy procedures, as well as that regarding the implementation of the state policy in the sphere of financial recovery and bankruptcy;

The Ministry for the Management of State Property of Russia:

- executes the powers of a representative of the owner of a debtor's property - a federal state unitary enterprise - during the implementation of bankruptcy procedures, except in the instances when by decision of the RF Government the said powers are delegated to another federal body of executive authority or to a juridical or physical person;

The Interdepartmental Commission:

- determines the feasibility of filing a petition that debtors belonging to Categories A and B be deemed to be bankrupt.

In 2004, the "balance of forces" between the bodies of authority as regards the sphere of regulation and practical application of bankruptcy procedures underwent a fundamental change. By Edict of the RF President of 09.03.2004 No. 314 "On the system and structure of the federal bodies of executive authority", the following measures were envisaged:

- the abolition of the FSFRB and the Ministry for the Management of State Property of Russia;

- the formation of the Federal Agency for Managing Federal Property and the transfer to it of some of the FSFRB's functions;

- the transfer to the RF Ministry for Economic Development and Trade the functions of adopting normative-legal acts in the FSFRB's established sphere of activity;

- the transformation of the RF Ministry for Taxes and Levies into the Federal Tax Service; 
- the transfer to the Federal Tax Service of the FSFRB's functions of representing the interests of the Russian Federation before creditors in bankruptcy procedures.

In accordance with the said Edict,

- $\quad$ by Decree of the RF Government of 07.04.2004 No. 187, the functions of developing the state policy and normative legal regulation were delegated to the RF Ministry for Economic Development and Trade, including in the sphere of organizations' insolvency (bankruptcy);

- $\quad$ by Decree of the RF Government of 08.04.2004 No. 200, the functions of executing, during bankruptcy procedures, the powers of the owner of a debtor property - a federal state unitary enterprise were delegated to the Federal Agency for Managing Federal Property.

By Decree of the RF Government of 29.05.2004 No. 257 (hereinafter Decree No. 257), it was established that prior to the transformation into the Federal Tax Service, the empowered agency responsible for representing, in bankruptcy cases and bankruptcy procedures, the claims in respect to mandatory payments and other claims of the Russian Federation concerning financial liabilities shall be the RF Ministry for Taxes and Levies (MTL). Also, the said document recognized the following as null and void:

- the paragraph in Decree No. 100 , stipulating that the empowered agency representing, in bankruptcy cases and bankruptcy procedures, the claims in respect to mandatory payments and other claims of the Russian Federation concerning financial liabilities shall be the FSFRB;

- Decree No. 218;

- Decree No. 688.

Finally, Decree No. 257 approved the Provision on the procedure for presenting claims concerning the liabilities to the Russian Federation in bankruptcy cases and bankruptcy procedures, wherein, in particular, the following was stipulated:

- in the event of a debtor having failed to satisfy the Russian Federation's claims in the amount established by the Law on bankruptcy, the empowered body, in the established period, makes the decision 
concerning the petitioning to the arbitrage court that the debtor be deemed to be bankrupt;

- the procedure for making the decisions concerning the recognition, as bankrupt, of a debtor included in the list of strategic enterprises and organizations is to be established by the RF Ministry for Economic Development and Trade;

- the procedure for the choice of a SRO by an empowered body, when filing a petition against a debtor with the arbitrage court, is to be established by the RF Ministry for Economic Development and Trade;

- the empowered body, when participating in a creditors' meeting, votes in the procedure established by the RF Ministry for Economic Development and Trade;

- the empowered body, prior to participating in a creditors' meeting, the agenda of which contains the issue concerning the choice of a bankruptcy procedure, requests the opinion of a corresponding body of executive authority of a RF subject and a local selfgovernment body in respect to the application of bankruptcy procedures and the process of implementing the bankruptcy procedure;

- the federal bodies of executive authority, the bodies of executive authority of RF subjects and local self-government bodies have the right to request from the empowered body the information concerning the process of implementing bankruptcy procedures;

- the empowered body, on a quarterly basis, submits to the RF Ministry for Economic Development and Trade and the RF Ministry of Finance the information concerning bankruptcy cases and bankruptcy procedures;

- the empowered body, once in a half-year, submits to the RF Ministry for Economic Development and Trade analytical and statistical reports, as well as other information, on the Ministry's request, no later than 30 days after the date on which the request was received.

As a brief summary of the information presented above, the Table 1 shows the distribution of the main functions and powers regarding the regulation and practical implementation of the institution of bankruptcy between the bodies of executive authority as of 1 January and 1 June of the current year. 
Assignment of main functions and powers on regulation and implementation of the institution of bankruptcy between executive power agencies

\begin{tabular}{|c|c|c|}
\hline Functions & 01.01 .2004 & 01.06 .2004 \\
\hline $\begin{array}{l}\text { General regulation, } \\
\text { adoption of normative }\end{array}$ & FSFRB & $\begin{array}{l}\text { RF Ministry for Economic } \\
\text { Development and Trade }\end{array}$ \\
\hline $\begin{array}{l}\text { Making decisions } \\
\text { concerning petitions } \\
\text { that debtor be } \\
\text { deemed to be bank- } \\
\text { rupt }\end{array}$ & $\begin{array}{l}\text { in respect to Category A } \\
\text { debtor - by RF Government, } \\
\text { Chairman of RF Government, } \\
\text { or, by latter's commission, by } \\
\text { Deputy Chairman of RF Gov- } \\
\text { ernment, in respect to Cate- } \\
\text { gories B-D debtors - by } \\
\text { FSFRB }\end{array}$ & $\begin{array}{l}\text { MTL* } \\
\text { procedure for making deci- } \\
\text { sions as to debtor included in } \\
\text { list of strategic enterprises } \\
\text { and organizations being } \\
\text { deemed to be bankrupt is } \\
\text { established by RF Ministry for } \\
\text { Economic Development and } \\
\text { Trade }\end{array}$ \\
\hline $\begin{array}{l}\text { Voting at creditors' } \\
\text { meetings }\end{array}$ & $\begin{array}{l}\text { FSFRB } \\
\text { concerning choice of bank- } \\
\text { ruptcy procedure - with re- } \\
\text { gard to opinion of body of } \\
\text { executive authority of RF } \\
\text { subject and local self- } \\
\text { government body }\end{array}$ & $\begin{array}{l}\text { MTL } \\
\text { concerning choice of bank- } \\
\text { ruptcy procedure - with re- } \\
\text { gard to opinion of body of } \\
\text { executive authority of RF } \\
\text { subject and local self- } \\
\text { government body }\end{array}$ \\
\hline $\begin{array}{l}\text { Execution of powers } \\
\text { of owner of debtor's } \\
\text { property - federal } \\
\text { state unitary enter- } \\
\text { prise - during imple- } \\
\text { mentation of bank- } \\
\text { ruptcy procedures } \\
\text { Control over SRO's } \\
\text { activity }\end{array}$ & $\begin{array}{l}\text { RF Ministry for the Manage- } \\
\text { ment of State Property }\end{array}$ & $\begin{array}{l}\text { Federal Agency for Managing } \\
\text { Federal Property }\end{array}$ \\
\hline
\end{tabular}

\subsection{Prospects for the modification of bankruptcy legislation}

After approximately one year since the adoption of the new Law on bankruptcy, the state authorities began to improve it and, no less importantly, to bring the provisions contained in other legislative acts in conformity with this Law. Thus, the meeting of the RF Government on 25 December 2003 on the whole approved the draft plan for the RF Government's activity to implement, in 2004, the medium-term program of 
socio-economic development (2003-2005) submitted by the RF Ministry for Economic Development and Trade. This document, in particular, envisaged the following:

- the improvement of criminal and administrative legislation, as well as bankruptcy legislation in the part concerning the responsibility for law violations and crimes committed in the event of bankruptcy;

- the determination of the procedure and conditions for the participation of an empowered body in financial rehabilitation procedures and amicable settlement in bankruptcy, by means of making amendments to the Law on bankruptcy and adopting a special Decree by the RF Government;

- the improvement of the Law on bankruptcy in the part concerning:

- the refinement of the notion of current payments,

- the clarification of the requirements to a bankruptcy commissioner,

- the clarification of the consequences of relief or dismissal of a bankruptcy commissioner,

- the clarification of the status of compensation funds,

- the clarification of the status of mutual insurance societies,

- the clarification of the procedures for property sales during financial rehabilitation and external administration,

- the development of self-regulation.

The implementation of the first measure was planned for October 2004 (submitting the corresponding draft laws to the RF State Duma of the Federal Assembly), of the last two - for November 2004.

Then, at the same meeting of the RF Government on 25 December 2003, the draft plan for the preparation of draft laws by RF Government in the year 2004, submitted by the RF Ministry of Justice, was approved. This document, in particular, envisaged the following:

- the consideration, by the RF Government, in March, and the submitting to the State Duma in April 2004 of the draft law "On introducing amendments to the Tax Code of the Russian Federation and the Federal Law "On insolvency (bankruptcy)" in the part determining the procedure for adopting the decision by the empowered body as to the timelines for debt redemption in respect to taxes, levies and fines during financial rehabilitation and amicable settle- 
ment in bankruptcy procedures. In this connection, it was established that the purpose of the draft law was to be as follows:

- to create the legal foundation for bankruptcy procedures, financial rehabilitation and amicable settlement,

- to provide adequate opportunities for amicable settlements in bankruptcy procedures, when the main creditor is the Russian Federation;

- the consideration, by the RF Government, in March, and the submitting to the State Duma in May 2004 of the draft law "On introducing amendments to the Civil Code of the Russian Federation, the Budget Code of the Russian Federation, the Criminal Code of the Russian Federation, the Code of the Russian Federation on Administrative Violations", in the part concerning bringing their norms in conformity with the Law on bankruptcy. In this connection, it was envisaged that the draft law would bring the norms stipulated in the said laws in conformity with the Law on bankruptcy in the part concerning the following:

- expanding the range of juridical persons in respect to which the application of bankruptcy procedures is admissible,

- bringing the issues concerning the priorities of satisfying creditors' claims in conformity with existing legislation on bankruptcy;

- the consideration, by the RF Government in September, and the submitting to the State Duma in October 2004 of the draft law "On introducing amendments to the the Federal Law "On insolvency (bankruptcy)" in the part concerning the following:

- the clarification of the requirements to a bankruptcy commissioner,

- the clarification of the consequences of relief or dismissal of a bankruptcy commissioner,

- the clarification of the procedures for property sales during financial rehabilitation and external administration,

- the development of self-regulation.

In this connection, it was determined that the purpose of the draft law should be:

- to eliminate the intrinsic contradictions in the Law on bankruptcy, 
- to eliminate the non-conformities between the Law on bankruptcy and the RF Civil Code and the RF Code of Arbitrage Procedure,

- to refine the norms concerning some specific bankruptcy procedures;

- the consideration by the RF Government in September, and the submission to the State Duma in October 2004 of the draft law "On introducing amendments to the Criminal Code of the Russian Federation and the Code of the Russian Federation on Administrative Violations" in the part concerning the clarification of the provisions on premeditated and fictitious bankruptcy, and unlawful actions in bankruptcy. In this connection, it was established that the purpose of the draft law was to be as follows:

- property protection from criminal infringements and violations of the law,

- prevention of crimes and violations of the law through improving the efficiency of the provisions of the RF Criminal Code and the RF Code on Administrative Violations, which establish the responsibility for violations of the law during bankruptcy procedures and in anticipation of bankruptcy.

Finally, at the RF Government's meeting on 26.02.2004, the concept and draft technical assignment were approved for developing the draft Federal Law "On introducing amendments to the Tax Code of the Russian Federation and the Federal Law "On insolvency (bankruptcy)". The changes envisaged in this document were oriented to eliminating the non-conformities between the Law on bankruptcy and the RF Tax Code, the essence of those non-conformities being that the former requires that the schedule of debt redemption in respect to mandatory payments in the course of financial rehabilitation and the terms of an amicable settlement as to the redemption of arrears mandatory payments be compatible with the norms established by legislation on taxes and levies, while the latter established neither the foundation nor the procedure for the empowered bodies to make decisions that would allow for the inclusion of such provisions in the schedule of debt redemption and an amicable settlement. This discrepancy, as stated in the concept, "not only prevents the restoration of a debtor's solvency within the framework of the proceedings in bankruptcy and the application of such 
a rehabilitative procedure as financial recovery, or an amicable settlement, but also may result in the debtor's liquidation within the framework of bankruptcy procedures".

The modifications planned by the RF Government, in our opinion, "cover" almost the whole spectrum of the currently existing flaws and gaps in the Law on bankruptcy, and, in the event of their successful implementation, will make it possible to considerably improve the quality of this document. However, we believe it important to note the following two circumstances:

- a number of important changes to the Law on bankruptcy, envisaged in the draft plan for the activity of RF Government in respect to the implementation, in the year 2004 , of the medium-term program of socio-economic development (the years 2003-2005), were not reflected in the RF Government's draft plan for preparing draft laws in the year 2004. In particular, this is true of certain changes aimed at improving the regulation of SROs' creation and activity, e.g., a more precise definition of the status of compensation funds and mutual insurance societies;

- $\quad$ at present, the schedule for preparing draft laws is not being complied with: by the autumn of 2004, none of the draft laws, intended for the submission to the State Duma in April-May 2004, had actually been submitted. 


\section{Chapter 3. Bankruptcy issues in regional legislations}

The problems relating to bankruptcies of enterprises, absent debtors, and enforced liquidation of juridical persons are typical of almost all Russian regions. This also accounts for the existence of the regional legislative base for the issues relating to enterprises' insolvency (bankruptcy), which seems, at a first glance, to be sufficiently welldeveloped $^{87}$.

All these normative acts can be conventionally subdivided into two groups: those addressing the prevention of bankruptcy and those determining the bankruptcy procedure for enterprises. Nevertheless, it should be noted that the problem of preventing enterprises' insolvency almost always is reduced to the state support for some of them, while the procedure of bankruptcy - to the issue of an enterprise's arrears of debt to a region's budget. Thus, the normative base in the Russian Federation's regions in respect to enterprises' insolvency is rather imperfect and uniform.

In many cases, the enterprises entitled to the state support are established at a region's level simply in the form of a list (e.g., in the Republic of Tatarstan ${ }^{88}$, the Republic of Khakassia ${ }^{89}$, Krasnoyarsk Krai ${ }^{90}$, etc.), however there also are some examples of regional normative acts, where the criteria for placing a certain enterprise in a group with the right to demand a special approach are clearly defined.

In some instances, the criteria for determining such enterprises are purely quantitative ("enterprises forming company towns"). For example, in accordance with the Law of Volgograd Oblast "On enterprises

\footnotetext{
${ }^{87}$ Only the normative acts that came into force after the enactment of the 1998 Federal Law "On insolvency (bankruptcy)", except those that are not in force or have lost their force, are taken into consideration.

${ }^{88}$ Decree of the Cabinet of Ministers of the Republic of Tatarstan of 13 July 1999 No. 431 "On preventing insolvency and the financial recovery of enterprises and organizations of the Republic of Tatarstan" (as of 13.10.2000 No. 723).

${ }^{89}$ Decree of the Supreme Council of the Republic of Khakassia of 24 June 1999 No. 28515 "On approving the list of socially relevant enterprises of the Republic of Khakassia" (as of 12.01.2000 No. 2-p).

${ }^{90}$ Decree of the Administration of Krasnoyarsk Krai of 7 September 2000 No. 681-P "On approving the list of large organizations, economically and (or) socially relevant for the Krai".
} 
forming company towns", state support may be granted to an enterprise or organization whereat no less than one-half of a settlement's population (including families), or no less than $30 \%$ of the total working population (employed at enterprises or organizations) of this settlement are employed, or if it lists, among its fixed assets, objects of the utilities or engineering infrastructure servicing no less than $30 \%$ of the municipal entity's population, or if the specific weight of its tax revenues constitutes no less than $10 \%$ of the Oblast's budget tax revenues, or no less than $15 \%$ of the city budget tax revenues, or no less than $30 \%$ of the regional budget tax revenues ${ }^{91}$. There is a special stipulation to the effect that "this Law shall also be applied to organizations whose number of employees exceeds five thousand persons in cities of Oblastlevel relevance, and one thousand persons in other settlements".

Such enterprises are provided with state support, including "for preventing their insolvency (bankruptcy)", in the following forms: "restructuring arrears of taxes and levies in accordance with the normative legal acts of the Russian Federation and Volgograd Oblast, restructuring the debts to organizations and enterprises - suppliers of fuel and electric power, granting deferrals of debt repayment and installment plans in respect to mandatory payments to the Oblast budget, granting tax credit or investment tax credit in the procedure and on the conditions as envisaged by existing tax and budget legislation, issuing Volgograd Oblast's guarantees to organizations' liabilities, including when granting credits and money loans, in accordance with existing budget legislation" ${ }^{92}$.

In other cases, the criteria for categorizing enterprises are qualitative. One of the most detailed normative acts of this type is the Provision "On reorganization of and state financial support to enterprises", which is in effect in the Republic of Altai. Thereby, state support is granted to those enterprises "which would be capable of reviving economic activity in various branches of the economy, primarily in that part of the production infrastructure that is needed for accelerating the technological transformation of the production process"; which manufacture "competitive, import-substituting and export products, including by applying

\footnotetext{
${ }^{91}$ Law of Volgograd Oblast "On enterprises forming company towns in Volgograd Oblast" of 19 April 2001 (Law of Volgograd Oblast, as amended on 13.06.2001, No. 550-OD).

${ }^{92}$ Ibid.
} 
unique "breakthrough" technologies"; "whose production to a significant degree depends on supplies of raw materials, spare parts and equipment from the countries of near and far abroad, and where presently there are no guarantees of stable import due to shortage of hard currency and disrupted economic connections"; which "produce energy-conserving equipment and implement new progressive technologies enhancing labor productivity, improving the social conditions of labor, relying on the application of innovative materials, automation, and promoting environmental safety of production"; which create appropriate conditions for "increasing investment activity" and have "broad cooperative inter-branch and inter-regional connections".

The selection of enterprises also takes into account the estimated "social consequences of the stoppage of certain enterprises and productions in terms of the labor market's formation and employment regulation", including "the balances of credit and debit indebtedness, ratios of liabilities and reevaluated assets, the degree of asset liquidity", etc ${ }^{93}$.

An example of a municipal act addressing the issues of bankruptcy prevention is "The Provision on the procedure for Irkutsk City Administration's participation in the bankruptcy procedure for organizations", where, in particular, it is stated that the City Administration, "in order to prevent bankruptcies of organizations, jointly with the territorial agency of the Federal Insolvency (Bankruptcy) Agency, participates in developing and implementing programs for social protection of employees during bankruptcies of organizations; analyses the economic and financial status of organizations displaying the indicia of bankruptcy, and keeps their register" $"$.

The normative acts concerning the issues of financial recovery as a pre-trial procedure also are in force in other regions - in Primorskii Krai, Ivanovo Oblast ${ }^{95}$, Bashkortostan (the republican budget every year allo-

\footnotetext{
${ }_{93}^{93}$ Provision "On reorganization of and State financial support to enterprises", approved by the Government of the Republic of Altai of 15 June 1999 No. 222.

${ }^{94}$ Provision "The Provision on the procedure for Irkutsk City Administration's participation in the bankruptcy procedure for organizations", Annex to Decree of Irkutsk City Mayor of 29 December 1998 No. 031-06-1575/8.

95 "Main areas of the activity aimed at financial rehabilitation of enterprises (organizations) registered on the territory of Ivanovo Oblast", approved by Decree of the Government of Ivanovo Oblast as of 04.07.2001, No. 60-p.
} 
cates "the necessary amount of funds for the support of enterprises during their restructuring, reorganization and liquidation) ${ }^{96}$, the Republic of Buriatia (the State Tax Inspectorate for the Republic of Buriatia and the federal off-budget funds for the Republic of Buriatia must, prior to petitioning with the Republic's Arbitrage Court that an organization be deemed to be bankrupt, to ensure, in the procedure of pre-trial reorganization, that the economic status of those organizations be reviewed for the purposes of financial recovery." In this connection, "the reviewing is mandatory for budgetary, socially relevant organizations and enterprises whose debts have arisen as a result of fulfilling state orders" ${ }^{97}$ ), etc.

In some regions, there exist normative acts designed to support enterprises belonging to certain branches of the economy. Thus, in Volgograd, a special decree of the Oblast Administration was adopted in order to prevent bankruptcies of agricultural enterprises ${ }^{98}$.

A serious problem is also associated with premeditated bankruptcies of enterprises. Thus, in the Republic of Tatarstan there exists a coordinating experts' council "with the participation of representatives of law-enforcement, tax and other supervisory agencies", which performs the functions of "coordinating the activities and developing a complex of measures designed to create and ensure the functioning of a system for preventing premeditated bankruptcies of juridical persons in the Republic of Tatarstan, as well as of preparing appropriate proposals and expert's estimations in respect to certain juridical persons" ${ }^{\text {" }}$.

As for the issues associated with the bankruptcy procedure as such for enterprises, here the majority of acts address two basic points: the relations of a debtor with the budgets of all levels, and the department performing executive, authorization, supervisory and organizational

${ }^{96}$ Decree of the Cabinet of Ministers of the Republic of Bashkortostan of 29 April 1998 No. 85 "On the activity of the Republican Insolvency (Bankruptcy) Agency at the State Committee of the Republic of Bashkortostan for Managing State Property".

${ }^{97}$ Regulation of the Government of the Republic of Buriatia of 24 March 1999, No. 263-r

${ }^{98}$ Decree of the Head of Administration of Volgograd Oblast of 15 March 1999 No. 169

"On measures designed to prevent the bankruptcy of agricultural enterprises on the territory of Volgograd Oblast".

${ }^{99}$ Decree of the President of the Republic of Tatarstan of 1 August 2001 No. UP-655 "On measures designed to prevent premeditated bankruptcy of juridical persons in the Republic of Tatarstan". 
functions in a bankruptcy procedure, as well as the creditor's functions, on behalf of the State, in respect to debtor enterprises. Thus, in Kursk Oblast the legislative base concerning bankruptcy contains, almost exclusively, the acts which deal with restructuring the enterprises' arrears of payments to the Oblast budget.

According to the general rule, the State's interests in the bankruptcy procedure for enterprises are represented (alongside with the creditor's functions) by either the Committee (or Ministry) for managing state property, or by its department (as, for example, in the Republic of Bashkortostan ${ }^{100}$, Altai Krai ${ }^{101}$, Saratov Oblast ${ }^{102}$, Voronezh Oblast ${ }^{103}$ ), or by a territorial agency of the FSFRB or its subdivision (the Republic of Buriatia $^{104}$, the Republic of Karelia ${ }^{105}$, the Republic of Chiuvashia ${ }^{106}$,

\footnotetext{
${ }^{100}$ Decree of the Cabinet of Ministers of the Republic of Bashkortostan "On the Republican Bankruptcy and Financial Rehabilitation Agency" of 2 June 1999 No. 158.

${ }^{101}$ Decree of the Administration of Altai Krai "On additional measures for efficient implementation of RF legislation on insolvency (bankruptcy) in the territory of Altai Krai" of 7 March 2000 No. 179.

${ }^{102}$ Decree of Saratov Oblast Duma "On delegating to the Saratov Oblast's Ministry for Property and Bankruptcy Affairs the powers of a creditor in respect to money liabilities to the oblast budget" of 7 July 1998 No. 16-383.

${ }^{103}$ Decree of the Administration of Voronezh Oblast "On organizational measures designed to implement the RF Law "On insolvency (bankruptcy)" in the territory of Voronezh Oblast" of 3 September 1998 No. 856.

${ }^{104}$ Decree of the Government of the Republic of Buriatia "On measures designed to implement Law of the Russian Federation of 08.01.98 6-FZ "On insolvency (bankruptcy)" of 13 May 1998 No 159.

${ }^{105}$ Decree of the Chairman of the Government of the Republic of Karelia "On concluding the Agreement "On delegating powers of the RF Federal Service for Insolvency and Financial Rehabilitation" of 16 March 1999 No. 130.

${ }^{106}$ Decree of the Cabinet of Ministers of the Republic of Chiuvashia of 13 April 2001 No. 72 "On the Agreement with the RF Federal Service for Insolvency and Financial Rehabilitation".
} 
Krasnoyarsk Krai ${ }^{107}$, Archangel Oblast ${ }^{108}$, Ivanovo Oblast ${ }^{109}$, Kostroma Oblast $^{110}$, Moscow Oblast ${ }^{111}$, St. Petersburg ${ }^{112}$, etc.).

However, there are also some exceptions. Thus, in Novosibirsk Oblast, the state agency "performing executive, supervisory, authorization, regulatory and organizational functions in order to efficiently resolve the problems arising in insolvency (bankruptcy) and financial rehabilitation of organizations" is the linsolvency (Bankruptcy) Agency of Novosibirsk Oblast Administration ${ }^{113}$. And in the Republic of Sakha (Yakutia) the function of petitioning to the Arbitrage Court that an enterprise with arrears of payments to the republican budget be deemed to be bankrupt is delegated to the Republican Service for reforming and bankruptcy at the Republic's Government, which performs it in coordination with branch departments ${ }^{114}$.

In Moscow, the city's interests as a creditor in respect to liabilities and arrears of mandatory payments are represented in the arbitrage court by the Moscow Insolvency (Bankruptcy) Committee, while a specially established commission for non-payments and bankruptcy, among other issues, "develops recommendations for financial rehabilitation of the organizations - debtors of the Complex of City Services,

\footnotetext{
107 "Provision on the Department for Krai property", approved by Decree of Krasnoyarsk Krai's Administration of 27 June 2001 No. 466-P.

${ }^{108}$ Decree of the Head of Administration of Archangel Oblast "On delegating rights to the Territorial Agency of the RF Federal Service for Insolvency and Financial Rehabilitation in Archangel Oblast" of 19 March 2001 No. 84.

${ }^{109}$ Regulation of the Head of Administration of Ivanovo Oblast "On delegating the powers of the RF Federal Service for Financial Rehabilitation and Bankruptcy" of 28 June 2001 No. 722-r.

${ }^{110}$ Decree of the Governor of Kostroma Oblast "On delegating powers to the Territorial Agency of the RF Federal Service for Financial Rehabilitation and Bankruptcy in Kostroma Oblast" of 19 April 2001 No. 167.

${ }^{111}$ Decree of the Government of Moscow Oblast "On implementing in the territory of Moscow Oblast of legislation of the Russian Federation on insolvency (bankruptcy) of enterprises" of 9 February 1998 No. 13/4.

${ }^{112}$ Regulation of St. Petersburg's Administration "On measures designed to extend the practice of initiating bankruptcy procedures in respect to organizations with arrears of payments to the budget of St. Petersburg" of 2 August 2001 No. 581-ra.

113 "Provision on the Insolvency (Bankruptcy) Agency of Novosibirsk Oblast's Administration" approved by Decree of the Head of the Oblast Administration of 01.04.99 No. 206.

${ }^{114}$ Decree of the Government of the Republic of Sakha (Yakutia) "On measures designed to improve the efficiency of implementing bankruptcy procedures in the Republic of Sakha (Yakutia)" of 13 February 2001 No. 75.
} 
through the application of economic and legal levers", and "creates appropriate conditions for restructuring the financial liabilities of the organizations - debtors of the Complex of City Services, in order to improve the economic efficiency of their activity"115.

As a rule, the same regional agency works with specialists in anticrisis administration (bankruptcy commissioners), which includes their training, certification and licensing (for example, in Kaluga Oblast - the FSFRB's territorial agency, by referrals of municipal formations ${ }^{116}$ ), the supervision of their activity (in particular, in Altai Krai - the Krai Committee for Managing State Property ${ }^{117}$ ), etc. However, here there are also some exceptions - in Astrakhan Oblast it is recommended that not only the selection, but also the training of bankruptcy commissioners for their appointment to bankrupt enterprises be done by Heads of Administration of municipal formations ${ }^{118}$.

The funding for the training of bankruptcy commissioners, as a rule, comes from a region's budget (for representatives of a region's executive authority or bodies of local self-government), or from those enterprises that have sent them, and for unemployed - from the employment funds (for example, in the Republic of Bashkortostan ${ }^{119}$ ).

Much attention in the regions is being paid to developing a consolidated position for all state organizations - creditors of bankrupts. Thus, in the Republic of Sakha all related organizations with the right to file a petition in bankruptcy must submit "the documents necessary for applying to the arbitrage court with a single petition containing consolidated claims to the debtor" to the Republican Service for Insolvency

\footnotetext{
${ }^{115}$ Regulation of the Mayor of Moscow "On creating the Commission of the Moscow Government for non-payments and bankruptcies of organizations indebted to the city services" of 8 April 1998 No. 344-RM.

${ }^{116}$ Decree of the Government of Kaluga Oblast "On the activity of the Territorial Agency of the RF Federal Service for Insolvency and Financial Rehabilitation in Kaluga Oblast aimed at ensuring an interaction with the bodies of local self-government" of 27 November 1998 No. 125.

${ }^{117}$ Decree of the Administration of Altai Krai "On additional measures for efficient implementation of RF legislation on insolvency (bankruptcy) in the territory of Altai Krai" of 7 March 2000 No. 179.

${ }^{118}$ Decree of Head of Administration of Astrakhan Oblast "On the efficiency of implementing bankruptcy procedures in the Oblast" of 29 January 1999 No. 25.

${ }^{119}$ Decree of the Cabinet of Ministers of the Republic of Bashkortostan "On training crisis management specialists" (bankruptcy commissioners) of 29 September 1999 No. 311.
} 
and Financial Rehabilitation at the Ministry for State Property of Yakutia. In this connection, "the consolidated position of the State, when the cases of bankruptcy of juridical persons are being considered by an arbitrage court, is to be elaborated by the Board of empowered state representatives, to be created by the Republican Service for Insolvency and Financial Rehabilitation at the Ministry for State Property of the Republic of Sakha (Yakutia)" ${ }^{120}$.

In Volgograd Oblast, "the consolidated position of the State in the course of bankruptcy cases being considered by arbitrage courts is to be elaborated by the Board of empowered state representatives created by the FSFRB of Russia"121. In Lipetsk Oblast, it is recommended that the state departments "coordinate issues relating to initiating the proceedings in bankruptcy, as well as the candidates recommended for being appointed bankruptcy commissioners in charge of bankrupt enterprises, with the Territorial Agency of the RF Federal Service for Insolvency and Financial Rehabilitation in Lipetsk Oblast, as well as with Heads of Administrations of the Oblast's cities and regions"122.

In Moscow, a single commission for non-payments and bankruptcy in respect to the organizations - debtors of the Complex of City Services was established, which must ensure, among other things, the interaction between the federal and city departments concerning this issue $^{123}$. And in Voronezh Oblast, the responsibility "to coordinate the activities of the bodies of executive authority and the administration when effectuating bankruptcy procedures was delegated to the commission

\footnotetext{
${ }^{120}$ Decree of the Government of the Republic of Sakha (Yakutia) "On the procedure for creating and running the Board of empowered state representatives who develop the State's consolidated position concerning the proceedings in bankruptcy against debtors - juridical persons" of 15 January 2000 No. 16.

${ }^{121}$ Letter of the Administration of the RF Ministry for Taxes and Levies for Volgograd Oblast of 5 May 2000 No. 03-15/204.

${ }^{122}$ Decree of the Head of Administration of Lipetsk Oblast "On increasing control over the bankruptcy procedure" of 28 September 1998 No. 375.

${ }^{123}$ Regulation of the Mayor of Moscow "On creating the Commission of the Moscow Government for non-payments and bankruptcies of organizations indebted to the city services" of 8 April 1998 No. 344-RM.
} 
for redemption and restructuring of arrears of payments to the oblast and local budgets of Voronezh Oblast ${ }^{124}$.

The region, in the person of an agency performing the creditor's functions, as a rule, initiates a bankruptcy procedure in respect to an enterprise, if its total arrears of mandatory payments to the region's budget within three months from the date established for their execution exceed 500 minimum salaries (without penalties and fines). However, this provision is usually augmented by other stipulations. Thus, in St. Petersburg the enterprise with such arrears must also fail to comply with the schedule of repayments, the bankruptcy procedure being initiated primarily in respect to those enterprises whose main activities are "commerce, public catering and providing services to the population" 125 .

In Moscow Oblast, the bankruptcy procedure is initiated against those enterprises which for more than one year, have failed to engage in financial and economic activity, do not submit reports to the tax authorities, and have arrears of payments (for more than three months) to budgets of all levels and state off-budget funds, in excess of 500 minimum salaries, with an average number of employees of up to 15 persons $^{126}$.

Among the regions of the Russian Federation, the most welldeveloped legislative base concerning bankruptcies of juridical persons probably exists in the Republic of Tatarstan. In addition to normative acts concerning the usual issues (as those discussed above), the Republic has adopted documents containing methodological recommendations for evaluating the property of debtor enterprises ${ }^{127}$, the

\footnotetext{
${ }^{124}$ Decree of the Administration of Voronezh Oblast "On organizational measures designed to implement the RF Law "On insolvency (bankruptcy)" in the territory of Voronezh Oblast" of 3 September 1998 No. 856.

${ }^{125}$ Regulation of St. Petersburg's Administration "On measures designed to extend the practice of initiating bankruptcy procedures in respect to organizations with arrears of payments to the budget of St. Petersburg" of 2 August 2001 No. 581-ra.

${ }^{126}$ Decree of the Government of Moscow Oblast "On implementing in the territory of Moscow Oblast of legislation of the Russian Federation on insolvency (bankruptcy) of enterprises" of 9 February 1998 No. 13/4.

${ }^{127}$ Decree of the Cabinet of Ministers of the Republic of Tatarstan "The Provision concerning the procedure for the evaluation and sale of the property (including property rights) of
} 
procedure for restructuring socially relevant debtor organizations ${ }^{128}$, the procedure for enforced liquidation of juridical persons (this Commentary of the Arbitrage Court mostly addresses various aspects of federal legislation) $)^{129}$, the procedure for evaluating and selling the property of insolvent enterprises and organizations ${ }^{130}$, the presence or absence of the indicia of fictitious or premeditated bankruptcy ${ }^{131}$, an accelerated procedure (within 21 days from the moment of submitting the documents) for registering the juridical persons being formed during the effectuation of insolvency (bankruptcy) procedures and financial rehabilitation ${ }^{132}$, etc.

It should also be noted that the regions' normative bases also contain many various overviews as provisions and explanations of federal legislation (Krasnodar Krai ${ }^{133}$, Primorskii Krai ${ }^{134}$ (in Primorskii Krai, certain provisions of federal legislation are also explained in the "Methodological Recommendations for applying legislation of the Russian Federation on insolvency (bankruptcy) ${ }^{135}$ ), Penza Oblast ${ }^{136}$, the city of

debtor organizations in the course of insolvency (bankruptcy) procedures" of 26 October 2000 No. 746.

${ }^{128}$ Decree of the Cabinet of Ministers of the Republic of Tatarstan "The Provision concerning the procedure for restructuring socially important debtor organizations with the purpose of their financial rehabilitation" of 26 October 2000 No. 742.

${ }^{129}$ Commentary by the Supreme Arbitrage Court of the Republic of Tatarstan "Enforced liquidation and bankruptcy of juridical persons (The problems of legislation and the juducual practice of arbitrage courts)".

${ }^{130}$ Decree of the Cabinet of Ministers of the Republic of Tatarstan "The Provision concerning the evaluation and sale of the property of enterprises and organizations in the course of implementing the procedure of external administration and the proceedings in bankruptcy in the Republic of Tatarstan" of 13 July 1999 No. 431.

${ }^{131}$ Regulation of the Committee of the Republic of Tatarstan for issues of insolvency and financial rehabilitation "The procedure for making a conclusion as to the presence or absence of the indicia of fictitious or premeditated bankruptcy" of 6 July 1999 No. 4r.

${ }^{132}$ Decree of the Cabinet of Ministers of the Republic of Tatarstan "On introducing an accelerated procedure for registering the juridical persons being created during the implementation of insolvency (bankruptcy) procedures and financial rehabilitation" of $11 \mathrm{Au}-$ gust 1999 No. 503.

${ }_{133}$ Information of the State Tax Inspectorate for Krasnodar "Enterprises undergo the bankruptcy procedure" of 29 December 1998.

${ }^{134}$ Explanations of the State Tax Inspectorate for Primorskii Krai of 12 March 1998 No. 16-07.

${ }^{135}$ Regulation of the Justice Institution "Primorskii Krai Registration Center" "Methodological Recommendations for applying legislation of the Russian Federation on insolvency 
Moscow $^{137}$ etc.), as well as the practice of arbitrage courts (the Republic of Khakassia ${ }^{138}$, Krasnodar $\mathrm{Krai}^{139}$, Novosibirsk Oblast ${ }^{140}$, Penza Oblast ${ }^{141}$, etc.).

By way of conclusion, an extract from the Commentaries of the Arbitrage Court of the Republic of Tatarstan may be cited here: "Existing legislation, establishing the foundation and procedure for the liquidation of juridical persons, is rather imperfect and has considerable gaps, which can be eliminated only by means of legislation. While the issues pertaining to the creation of juridical persons and the financing for the procedure of their State registration are to a certain extent determined by federal and regional legislations (although not fully, because the Law on the registration of juridical persons, the elaboration of which is envisaged in Article 51 of the Civil Code, has not been adopted yet), the procedure of enforced liquidation and the issues of funding for the liquidation procedures are in need of legislative regulation, otherwise the court decisions concerning the liquidation of juridical persons are not

(bankruptcy) when effectuating State registration of the rights to immovable property and the transactions therewith" of 10.08.1999 No. 71.

${ }^{136}$ Recommendation of the Procuracy of Penza Oblast "On eliminating violations of legislation on insolvency (bankruptcy)" of 6 April 2000 No. 7-5-31-2000.

${ }^{137}$ Letter of the State Tax Inspectorate for the City of Moscow "On providing information to bankruptcy commissioners" of 22 December 1998 No. 13-06/37857.

${ }^{138}$ Annex to the Information Letter of the Presidium of the Arbitrage Court of the Republic of Khakassia "On some issues pertaining to the practice of implementing, by the Arbitrage Court of the Republic of Khakassia of the Federal Law "On insolvency (bankruptcy)", when dealing with complaints concerning the actions of bankruptcy commissioners in insolvency (bankruptcy) cases" of 28.08.2000 No. 3.

${ }^{139}$ Information of the Administration of the RF Ministry for Taxes and Levies for Krasnodar Krai "The implementation of bankruptcy procedure" of 30 November 2000.

140 "An overview of the arbitrage practice considering the complaints filed by employees of bankrupt enterprises against the actions of the bankruptcy commissioners in charge of bankrupt organizations"; "An overview of the practice of consideration, by the Arbitrage Court of Novosibirsk Oblast, of the complaints of depositors and physical persons against the actions of the bankruptcy commissioners in charge of bankrupt credit organizations"; "An overview of the complaints of creditors of juridical persons against the actions of bankruptcy commissioners considered by the Arbitrage Court of Novosibirsk Oblast"; prepared by the Arbitrage Court in 2001.

141 "A generalization of the judicial practice of the suits of tax agencies concerning the liquidation of juridical persons considered by the Arbitrage Court of Penza Oblast in the year 2000", prepared by the Arbitrage Court in 2001. 
going to be implemented, which will entail violations of the lawful rights and interests of both creditors and the State" ${ }^{142}$.

142 "Enforced liquidation and bankruptcy of juridical persons (The problems of legislation and the juducual practice of arbitrage courts)" A commentary by the Supreme Arbitrage Court of the Republic of Tatarstan. 


\section{Chapter 4. The economic aspects of the formation of the institution of bankruptcy and the dynamics of cases}

\subsection{The specific economic and institutional conditions for applying bankruptcy procedures}

In the Russian situation, the influence of the institution of bankruptcy on the economy appears to be quite ambiguous, especially in respect to large-size business. The reason for this is not so much legal regulation of insolvency in Russia, but rather those specific economic and institutional conditions in which the institution of insolvency is "submerged". We should like to point out some of these conditions, which appear to be the most important ones.

First. Stale debts of Russian enterprises are mostly represented by arrears of taxes and other mandatory payments to off-budget funds between January 2001 and June 2002, on the average at the enterprises of the main branches of the economy, the specific weight of arrears of mandatory payments varied between $35 \%$ and $42 \%$ of the total volume of stale debts due to creditors. Moreover, in some of the most important branches of the processing industry the enterprises' arrears of payments due to the State were dominating among their total stale debts. Thus, as of the end of June 2002, total stale debts in the timberprocessing complex, light industry and machine-building amounted to about 59\%, 54\% and 50\%, respectively.

On the whole, neither the State nor private creditors had any motivation for applying bankruptcy procedures in order to ensure direct debt repayment. For the creditors in bankruptcy (fifth priority) it did not appear beneficial due to the high level of the enterprises' debts to the State, the latter, in accordance with the $2^{\text {nd }}$ Law on bankruptcy, being a preferred creditor (in respect to mandatory payments - fourth priority). For the State this was not the best procedure either, because prior to the enactment of the $3^{\text {rd }}$ Law on bankruptcy it had no means of exerting genuine influence on the effectuation of bankruptcy procedures. 
Second. The State, for objective reasons, is unable to apply bankruptcy procedures to all debtor enterprises. The main problem here is not so much the lack of appropriate law-enforcement infrastructure capable of "servicing" the necessary number of bankruptcies, but rather the high probability of negative effects of sectoral and territorial nature.

The Russian Law on bankruptcy enacted in 1998 was oriented to a developed market economy, where the specific weight of economic subjects in respect to which it might be necessary to apply bankruptcy procedures is negligible (about 3-4\%). However, the number of lossmaking enterprises in the Russian economy is much higher. After the August Crisis, the financial status of industrial enterprises improved, and the proportion of loss-making enterprises in the total number of organizations in industry somewhat decreased - from 49\% in late 1998 to $40 \%$ in late 2000 ; however, later, as the post-crisis growth factors were exhausting their potential, the situation once again began to deteriorate, and by the second half of 2002 this index had grown to almost $47 \%$. Judging by the results of a number of studies ${ }^{143}$, it can be stated that even by the beginning of 2000 (after a considerable increase in the liquidity of enterprises) the State, in accordance with the Law on bankruptcy (i.e., when an enterprise's arrears of taxes and other mandatory payments amount to more than 500 minimum salaries, delayed for more than three months), could have initiated the proceedings in bankruptcy, according to our estimation, against every other industrial enterprise. The gravest situation existed in machine-building, where the proceedings in bankruptcy could have been initiated against approximately $60 \%$ of all enterprises (while, for example, in light industry the same was true for only $20 \%$ of all enterprises).

\footnotetext{
${ }^{143}$ Project of the Bureau for Economic Analysis "Napravleniia i faktory restrukturizatsii promyshlennykh predpriiatii" (Areas and factors of restructuring industrial enterpreises) (Project Director - Kuznetsov B. V.).
} 
Table 2

An estimation of the range of enterprises in respect to which the State had the legal right to initiate bankruptcy procedures ${ }^{144}$

\begin{tabular}{|c|c|c|c|c|c|}
\hline \multirow[t]{2}{*}{ Industry } & \multicolumn{5}{|c|}{$\begin{array}{l}\text { Distribution of enterprises within sample depends on ratio of } \\
\text { their arrears of taxes as of beginning of } 2000 \text { to normative } \\
\text { threshold established for initiation of bankruptcy procedures }\end{array}$} \\
\hline & $\begin{array}{c}\text { Between } 0 \\
\text { and } 1\end{array}$ & $\begin{array}{l}\text { Between } 1 \\
\text { and } 50\end{array}$ & $\begin{array}{l}\text { Between } 50 \\
\text { and } 200\end{array}$ & $\begin{array}{l}\text { Over } \\
200\end{array}$ & Total: \\
\hline $\begin{array}{l}\text { Machine-building } \\
\text { and metal process- } \\
\text { ing }\end{array}$ & $39 \%$ & $27 \%$ & $15 \%$ & $19 \%$ & $100 \%$ \\
\hline $\begin{array}{l}\text { Construction ma- } \\
\text { terials }\end{array}$ & $42 \%$ & $28 \%$ & $20 \%$ & $10 \%$ & $100 \%$ \\
\hline $\begin{array}{l}\text { Chemistry and } \\
\text { petrochemistry }\end{array}$ & $58 \%$ & $16 \%$ & $8 \%$ & $18 \%$ & $100 \%$ \\
\hline Light industry & $58 \%$ & $20 \%$ & $15 \%$ & $7 \%$ & $100 \%$ \\
\hline $\begin{array}{l}\text { Forest, woodwork } \\
\text { and timber, pulp } \\
\text { and paper indus- } \\
\text { tries }\end{array}$ & $59 \%$ & $20 \%$ & $16 \%$ & $5 \%$ & $100 \%$ \\
\hline $\begin{array}{l}\text { Food industry } \\
\text { Sample's average }\end{array}$ & $\begin{array}{l}81 \% \\
54 \%\end{array}$ & $\begin{array}{l}15 \% \\
22 \%\end{array}$ & $\begin{array}{l}4 \% \\
14 \%\end{array}$ & $\begin{array}{l}0 \% \\
11 \%\end{array}$ & $\begin{array}{l}100 \% \\
100 \%\end{array}$ \\
\hline
\end{tabular}

Now we are going to discuss the possible consequences in the regional aspect. Russian regions are very unequal in their levels of socioeconomic development, and the trends of this development are multidirectional. In particular, in the first half-year of 2002, in Moscow and St. Petersburg the proportion of loss-making enterprises in the total number of enterprises was $27 \%$ and $28 \%$, respectively, whereas, for example, in the Republic of Buriatia - 55\%, and in Tambov Oblast $66 \%$. Also, one cannot overlook the high level of economic concentration in some Russian regions, which results in a situation when the regional budgets' tax revenues become critically dependent upon the results of the activity of only a few very large enterprises, and in this connection one may already speak not only of the company-town forming, but also of the "subject-forming" character of certain enterprises. Thus,

\footnotetext{
${ }^{144}$ An empirical base for the analysis was formed by the results of a survey of the enterprises of processing industries, conducred in April-May of 2000. The poll among 438 industrial enterprises was conducted by GfK and ordered by NERA (UK) and the Bureau for Economic Analysis.
} 
mass-scale application of bankruptcy procedures would result in an increased territory-wise non-uniformity of Russia's development.

Third. The existing budget constraints (imposed by the State) in respect to enterprises are non-uniform and non-transparent ${ }^{145}$, which creates unequal conditions in terms of competition. Without applying bankruptcy procedures to all indebted enterprises, the State could, nevertheless, set truly operative criteria for selecting appropriate objects for bankruptcy. Had this happened, the State's behavior would have become understandable for economic subjects and created the conditions for systematic, consistent "pressure" on debtors. But, in fact, in the absence of practically applicable criteria for bankruptcy procedures being initiated on the State's initiative, the institute of insolvency in its hands, instead of being an instrument for pushing inefficient enterprises from the market and enforcing financial discipline, have been turned into a factor responsible for the growth of investment risks in the economy and higher probability of the interference of representatives of state agencies with the activity of private businesses.

Fourth. In the Russian economy, there have been accumulated numerous non-operating enterprises, which maintain only a formal existence ${ }^{146}$. Some of them are fly-by-night firms, and some - "abandoned firms". According to the MTL, as of 1 October 2002, there were about 3.25 million organizations in the tax register, and about 1.3 million of them had not submitted tax reports, while about 260,000 had submitted "zero" balance sheets. After a campaign aimed at reregistering juridical persons ${ }^{147}$, as of 1 January 2003 , only 1.6 million organizations had entered their data in the Unified State Register of juridical persons.

The $2^{\text {nd }}$ Law on bankruptcy, due to a broadened interpretation of its articles concerning absent debtors, provided the MTL with a sufficiently

\footnotetext{
145 Simachiov Yu. Masshtaby i formy gosudarstvennoi podderhzki promyshlennykh predpriiatii, biudzhetnye ogranicheniia na mikrourovne, vliianiie na reformirovaniie biznesa (Scope and forms of state support to industrial enterprises, budget constraints at the microlevel, influence on business reforming). - ASPE Seriia nauchnykh dokladov (Series of scientific reports). M.: Trovant, 2002.

${ }^{146}$ According to the MTL's datra, as of October 1, 2002, a total of 3.25 million organizations were in the tax register, and approximately 1.3 million of them had not submitted tax reports, while about 260 thousand had submitted zero balance sheets.

${ }^{147}$ In accordance with the Law "On State registration of juridical persons and individual entrepreneurs".
} 
effective instrument for the judicial liquidation of such companies. It is not accidental that in the recently adopted 3rd Law on bankruptcy the possibilities for applying bankruptcy procedures to absent debtors have been restricted ${ }^{148}$.

Fifth. Recent years have been characterized by dynamically ongoing integration processes in industry, involving not only large, but also medium-sized businesses. Thus, within the already mentioned study, it was demonstrated ${ }^{149}$ that in terms of both growth dynamics and the average stake in enterprises' capital owned by outsiders, the first and second places are occupied by other industrial enterprises: almost $30 \%$ of the sample's enterprises, by the year 2000 , had maintained or further increased the degree of their dependence on other enterprises in their charter capital, and this degree, on the average, was very high. The following fact is noteworthy: at $22 \%$ of the sample's enterprises (Category 3), the average stake in their capital owned by other industrial enterprises grew from $6.5 \%$ to $44,5 \%$, or, in fact, to the initial level of Category 1.

The same study established that greater participation in capital by other industrial enterprises was associated with the appointment of external hired directors and "ousting" of CEOs from the board of directors, that represented, in effect, a "hostile" takeover. Naturally, such processes entailed various corporate conflicts (protection of CEOs from owners, including new ones, struggle for dominating control among different shareholders, etc.).

Against this background, two beneficial goals were simultaneously being achieved at the legislative level: within the framework of the Law on joint-stock companies, the provisions designed to protect shareholders' interests (first of all, those of minority shareholders) were strengthened, while within the framework of the law on bankruptcy, the rights of small creditors were defended. The first limited the opportunities for "hostile takeovers" and strengthened the control over CEOs" activity, while the second ensured easy initiation of bankruptcy proce-

\footnotetext{
${ }^{148}$ However, this restriction is augmented by a rather vague stipulation to the effect that bankruptcy procedures be applied to absent debtors only when appropriate funds are available in the budget.

${ }^{149}$ Project of the Bureau for Economic Analysis "Napravleniia i faktory restrukturizatsii promyshlennykh predpriiatii" (Areas and factors of restructuring industrial enterpreises), this aspect was studied by B. V. Kuznetsov.
} 
dures. This combination gave rise to additional demand, on the part of various parties involved, for bankruptcy procedures as an instrument for implementing practical tasks in the sphere of corporate governance.

\section{Changes in the degrees of participation in enterprises' capital on the part of other industrial enterprises}

\begin{tabular}{lccc}
\hline $\begin{array}{l}\text { Category of en- } \\
\text { terprises }\end{array}$ & $\begin{array}{c}\text { Sample's distribu- } \\
\text { tion by categories, } \\
\text { as percentage of } \\
\text { total number }\end{array}$ & $\begin{array}{c}\text { Participation at } \\
\text { moment of privati- } \\
\text { zation, as average } \\
\text { percentage }\end{array}$ & $\begin{array}{c}\text { Participation as of } \\
\text { beginning of year } \\
\text { 2000, as average } \\
\text { percentage }\end{array}$ \\
\hline $\begin{array}{l}\text { 0- no present or } \\
\text { past participation by } \\
\text { other industrial } \\
\text { enterprises }\end{array}$ & 62 & 0.0 & 0.0 \\
$\begin{array}{l}1-\text { no changes in } \\
\text { degree of participa- } \\
\text { tion by other enter- } \\
\text { prises }\end{array}$ & 7 & & 43.8 \\
$\begin{array}{l}2-\text { participation by } \\
\text { other enterprises } \\
\text { decreased }\end{array}$ & & & \\
$\begin{array}{l}3-\text { participation by } \\
\text { other enterprises } \\
\text { increased }\end{array}$ & 9 & & \\
\hline
\end{tabular}

Sixth. The inadequately developed executive infrastructure had a very negative impact on the opportunities for applying the norms on bankruptcy. This can be said of the low "traffic capacity" of arbitrage courts, the lack of the necessary number of qualified bankruptcy commissioners, and the excessive workload imposed on the staff of the FSFRB. In addition, we may also mention the very low level of practical application of the norms that determine the responsibility for abuses in the sphere of bankruptcy. For example, the norms established by the Law on bankruptcy have stipulated that a bankruptcy commissioner must repay the losses suffered by the debtor and the creditors, if he has violated existing legislation; however, we do not know any instances when actual court decisions were adopted to the effect that such losses be repaid. 


\subsection{The financial aspects of the activity of large industrial enterprises in the context of their potential insolvency}

The list of large, economically or socially relevant organizations for the year 2000 consisted of 1714 organizations, their total number of employees being more than 7 million. Among these, there were 242 state-owned organizations and 151 organizations with a more-than $50 \%$ State's share in their charter capital. The State's stake in 217 organizations was between $25 \%$ and $50 \%$. As for the other organizations on this list, the State's share in their charter capital was less than $25 \%$, or was altogether absent.

According to the FSFRB's analysis ${ }^{150}$ involving 1529 organizations with the total number of employees of 7,233 thousand, one may make an estimation as to the financial status of large and superlarge industrial enterprises. The trend toward a gradual improvement of the situation in respect to the enterprises' mutual settlements notwithstanding, one may, nevertheless, conclude that the number of potential bankrupts is still high, especially in machine-building and metal processing industries.

Table 4

Solvency of large industrial enterprises by industry

(according to the FSFRB's data)

\begin{tabular}{lccc}
\hline \multirow{2}{*}{\multicolumn{1}{c}{ Industries }} & \multicolumn{3}{c}{$\begin{array}{c}\text { Average solvency index concerning current } \\
\text { liabilities, by month }\end{array}$} \\
\cline { 2 - 4 } & $\begin{array}{c}\text { as of } \\
\mathbf{0 1 . 0 1 . 2 0 0 0}\end{array}$ & $\begin{array}{c}\text { as of } \\
\mathbf{0 1 . 0 7 . 2 0 0 0}\end{array}$ & $\begin{array}{c}\text { as of } \\
\mathbf{0 1 0 . 2 0 0 0}\end{array}$ \\
\hline $\begin{array}{l}\text { Machine-building and metal } \\
\text { processing }\end{array}$ & 8.8 & 7.3 & 7.2 \\
$\begin{array}{l}\text { Chemistry and petrochemistry } \\
\text { Metallurgy (ferrous and non- }\end{array}$ & 6.2 & 5.4 & 4.7 \\
$\begin{array}{l}\text { ferrous) } \\
\text { Forest and woodwork-and- }\end{array}$ & 5.8 & 4.9 & 4.7 \\
timber industries & 3.8 & 3.7 & 3.5 \\
All organizations & 7.5 & 6.5 & 6.3 \\
\hline
\end{tabular}

\footnotetext{
${ }^{150}$ FSFRB. Analiticheskii obzor finansovogo sostoiianiia krupnykh, ekonomicheski ili sotsial'no znachimykh organizatsii, podlezhashchikh obiazatel'nomu monitoringu so storonu FSFO (An analytical overview of the financial status of large, economically or socially important organizations which are subject to mandatory monitoring by the FSFRB of Russia. October 2000).
} 
It seems important also that attention be paid to the substantial variations of the averaged solvency index throughout the Okrugs and to the absence of any significant trends for the improvement of this index. Moreover, in the Far East Federal Okrug the solvency of largest enterprises began to worsen toward the end of the year 2000 .

Table 5

Estimated solvency of large industrial enterprises, throughout Federal Okrugs (according to the FSFRB's data)

\begin{tabular}{lccc}
\hline & \multicolumn{3}{c}{$\begin{array}{c}\text { Average solvency index concerning } \\
\text { current liabilities, by month }\end{array}$} \\
\cline { 2 - 4 } Federal Okrugs & $\begin{array}{c}\text { as of } \\
\mathbf{0 1 . 0 1 . 2 0 0 0}\end{array}$ & $\begin{array}{c}\text { as of } \\
\mathbf{0 1 . 0 7 . 2 0 0 0}\end{array}$ & $\mathbf{0 1 . 1 0 . 2 0 0 0}$ \\
\hline Central & 7.2 & 6.3 & 6.2 \\
North-West & 5.8 & 4.7 & 4.8 \\
South & 6.4 & 5.6 & 5.1 \\
Siberian & 10.9 & 9.0 & 8.9 \\
Volga & 6.1 & 5.8 & 5.4 \\
Urals & 7.7 & 7.0 & 6.7 \\
Far east & 11.2 & 8.7 & 9.0 \\
All organizations & 7.5 & 6.5 & 6.3 \\
\hline
\end{tabular}

As for superlarge enterprises, the distribution of their debts by the main creditor categories is rather specific: as seen by the sample's average, only $15 \%$ in the total arrears of payments is constituted by mandatory payments, $28 \%$ - by payments to banks, and the main bulk $53 \%$ - by payments to suppliers or other organizations.

In terms of liquidity, the sample's enterprises do not fair too badly on the average, each rouble of debt corresponds to 1.07 roubles of current assets; however, the financial stability of the sample's enterprises is very low: for example, at machine-building enterprises, 99\% of the current assets were formed by loaned funds.

On the whole, judging by the results of 9 months of the year 2000, $84 \%$ of the analyzed sample's enterprises had stale debts for more than 3 months. Given that the stale debt threshold established for the initiation of bankruptcy procedures is not high (especially as compared to the enterprises' scopes of business), it can be assumed that petitions in bankruptcy could have been filed in respect to every 17 out of 20 sample's enterprises. It should be noted in respect to this sample that while $43 \%$ of the enterprises of the forest-industry complex were solvent, the 
same indices in metallurgy and petrochemical industry amounted to approximately $30 \%$, and in machine-building - to only $15 \%$.

\section{Estimation of enterprises' financial stability (according to the FSFRB's data)}

\begin{tabular}{lccc}
\hline & \multicolumn{3}{c}{ Average index of enterprise's own stake in current } \\
andustries & \multicolumn{3}{c}{ assets, \% } \\
\cline { 2 - 4 } & $\begin{array}{c}\text { as of } \\
\mathbf{0 1 . 0 1 . 2 0 0 0}\end{array}$ & $\begin{array}{c}\text { as of } \\
\mathbf{0 1 . 0 7 . 2 0 0 0}\end{array}$ & $\begin{array}{c}\text { as of } \\
\mathbf{0 1 0 . 2 0 0 0}\end{array}$ \\
\hline $\begin{array}{l}\text { Machine-building and metal } \\
\text { processing }\end{array}$ & $1 \%$ & $4 \%$ & $1 \%$ \\
$\begin{array}{l}\text { Metallurgy (ferrous and non- } \\
\text { ferrous) }\end{array}$ & $-8 \%$ & $-1 \%$ & $-7 \%$ \\
$\begin{array}{l}\text { Chemistry and petrochemis- } \\
\text { try }\end{array}$ & $-5 \%$ & $-5 \%$ & $-7 \%$ \\
$\begin{array}{l}\text { Forest and woodwork-and- } \\
\text { timber industries }\end{array}$ & $-21 \%$ & $-13 \%$ & $-13 \%$ \\
$\quad$\begin{tabular}{l} 
All organizations \\
\hline
\end{tabular} & $-1 \%$ & $1 \%$ & $-0,3 \%$ \\
\hline
\end{tabular}

\subsection{The main trends in applying bankruptcy procedures during 1998-2002}

During the past four years, the number of bankruptcy cases have been steadily growing ${ }^{151}$. Especially impressive are the figures relating to the last two years: if in 2000 there were about 19,000 accepted petitions in bankruptcy, in 2001 their number grew to about 48,000, and in 2002 there were already more than 94,000 accepted petitions. As a result, while as of 1 January 2001 the proceedings in bankruptcy were going on in approximately 24 cases, as of 1 January 2002 the number of cases was already about 53,000, and as of 1 January 2003 - more than 102,000 .

It should be noted that despite the external evidence of a dramatically growing number of bankruptcy cases, it has little relation to the

\footnotetext{
${ }^{151}$ The estimations presented in this and the following sections are mainly based on the author's computations, using the arbitrage statictical data of 1998-2003. (Vestnik Vysshego Arbitrazhnogo suda Rossiiskoi Federatsii.- 1999 No. 3; 2000 No. 3; 2001 No. 4; 2002 No. 4; 2003 No. 4; 2004 No. 4), the data of the FSFRB, as well as those published in the report "Preduprezhdeniie bankrotstva: analiz statisticheskikh dannykh za 2003 god (Prevention of bankruptcy: an analysis of statistical data of the year 2003".
} 
true insolvency of the actually functioning enterprises. The main bulk of the petitions in bankruptcy filed in 2000-2002 were associated with implementing simplified bankruptcy procedures against absent debtors ${ }^{152}$, which has no relation whatsoever to issues like the losses suffered by large (socially important) enterprises, property redistribution, premeditated bankruptcies. Thus, the proportion of bankruptcy cases in respect to absent debtors or the debtors being liquidated in the total number of petitions in bankruptcy filed against debtors in 2002 was almost as high as $89 \%{ }^{153}$ (while in $2000-58 \%$, in $2001-82 \%$ ).

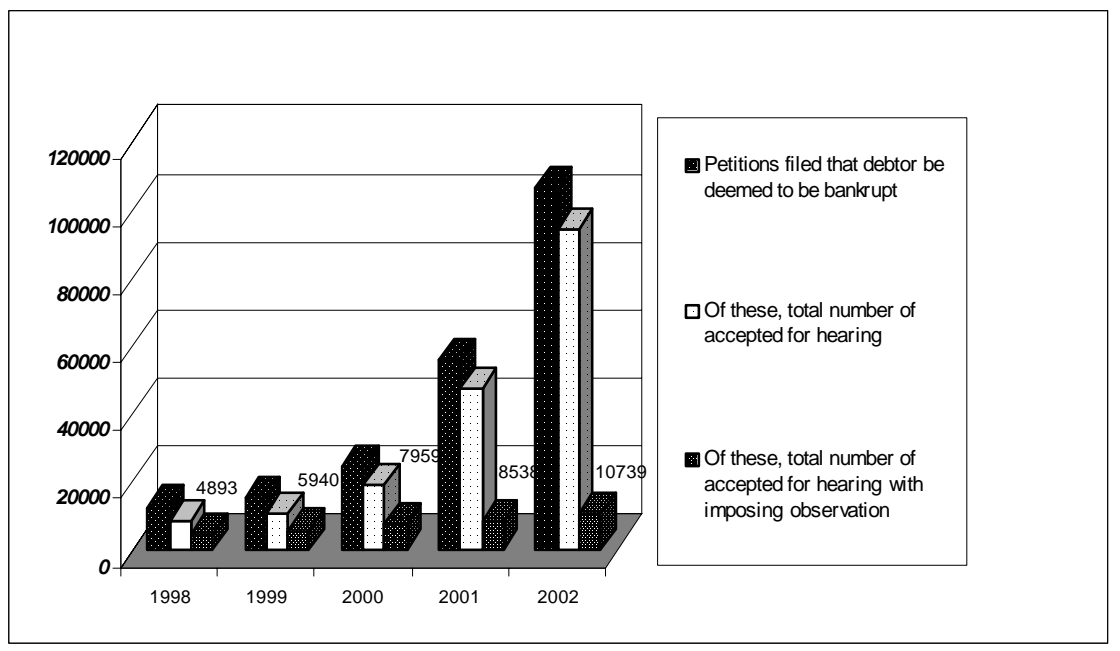

Fig. 3. Changes in the number of submitted and accepted petitions, and proceedings in bankruptcy being initiated against genuine debtors

Alongside the "overall" spread of bankruptcy procedures, they were also becoming more diversified in terms of their objects; thus, in 19992002 , the proportion, within the total number of petitions, of the peti-

\footnotetext{
${ }^{152}$ Kuznetsov B., Simachiov Yu. Praktika i rezultaty bankrotstva (Practice and results of bankruptcy). In: Rossiskaiia promyshlennost': institutsinal'noe razvitie (Russian industry: institutional development). - M: "TEIS". - 2002.

${ }^{153}$ More than 85 percent point in 2002 were constituted by bankruptcy cases in respect to absent debtors, and less than 4 percent point - by bankruptcy cases in respect to debtors being liquidated.
} 
tions filed against agricultural organizations, farms and individual entrepreneurs was growing, while almost at the same time, in 2001-2002, the proceedings in bankruptcy against city-forming enterprises became less numerous (down to 40-60 cases per annum).

Table 7

Proportion of petitions files in respect to some debtor categories

\begin{tabular}{|c|c|c|c|c|c|}
\hline \multirow[t]{2}{*}{ Debtor category } & \multicolumn{5}{|c|}{$\begin{array}{l}\text { Petitions in bankruptcy in respect to different } \\
\text { debtor categories in total amount of filed } \\
\text { petitions in bankruptcy, less those filed in } \\
\text { respect to debtors being liquidated and absent debtors, \% }\end{array}$} \\
\hline & 1998 & 1999 & 2000 & 2001 & 2002 \\
\hline $\begin{array}{l}\text { Agricultural organiza- } \\
\text { tions }\end{array}$ & 3.79 & 3.79 & 5.66 & 7.77 & 11.54 \\
\hline $\begin{array}{l}\text { Individual entrepre- } \\
\text { neurs }\end{array}$ & 1.15 & 1.35 & 1.42 & 3.77 & 5.34 \\
\hline $\begin{array}{l}\text { Peasants' (farmers') } \\
\text { farms } \\
\text { Citv-forming organi- }\end{array}$ & 0.41 & 0.72 & 1.85 & 3.32 & 9.63 \\
\hline zations & 1.40 & 1.06 & 0.40 & 0.19 & 0.26 \\
\hline
\end{tabular}

According to our estimations, the number of petitions in bankruptcy filed in respect to actually operating enterprises in industry, commerce, transport (we apply to them the arbitrary name - "substantive") and accepted for hearing were as follows: in 1998 - up to 5000, in 1999 - up to 6000 , in 2000 - up to 7000 , in $2001-$ up to 7500 , in 2002 - up to $7500^{154}$. Thus, it would not be incorrect (to put it mildly) to speak of any dramatic rise in the number of bankruptcies of industrial enterprises occurring in recent years.

By the intensity of their application, bankruptcy procedures are "pinpointed" and do not achieve, at the macrolevel, the goal of withdrawing inefficient enterprises from the market. The proportion of enterprises in respect to which bankruptcy procedures are effectuated is negligible, as compared to the total number of economic subjects (on the average, out of every 200 enterprises, only one is being bankrupt), especially if these figures are compared to the number of loss-making enterprises.

\footnotetext{
${ }^{154}$ In the years 2001-2002, the continuation of growth in the number of accepted petitions in bankruptcy, with subsequent introduction of supervision, was due to a considerable rise in the number of petitions filed against agricultural organizations and peasants' (farmers') farms.
} 


\section{Estimated intensity of applying bankruptcy procedures to economic subjects, region-wise}

\begin{tabular}{|c|c|c|c|}
\hline \multirow[t]{2}{*}{ Federal Okrugs } & \multicolumn{2}{|c|}{$\begin{array}{l}\text { Number of enterprises in respect to } \\
\text { which bankruptcy procedures are } \\
\text { effectuated, per } 1,000 \text { enterprises } \\
\text { (Okrug's average) }\end{array}$} & \multirow{2}{*}{$\begin{array}{c}\text { Reference: } \\
\text { number of loss-making } \\
\text { enterprises, per } 1,000 \\
\text { enterprises in } \\
2000 \\
\text { (Okrug's average) }\end{array}$} \\
\hline & $\begin{array}{c}\text { as of } \\
1 \text { January } 2001\end{array}$ & $\begin{array}{c}\text { as of } \\
1 \text { January } 2000\end{array}$ & \\
\hline Central Federal Okrug & 3.4 & 2.7 & 374 \\
\hline $\begin{array}{l}\text { North-Western Federal } \\
\text { Okrug }\end{array}$ & 6.4 & 4.3 & 355 \\
\hline $\begin{array}{l}\text { Southern Federal Ok- } \\
\text { rug }\end{array}$ & 7.8 & 3.8 & 346 \\
\hline Volga Federal Okrug & 9.6 & 5.8 & 416 \\
\hline Urals Federal Okrug & 4.4 & 3.0 & 418 \\
\hline Siberian Federal Okrug & 10.7 & 6.1 & 466 \\
\hline $\begin{array}{l}\text { Far Eastern Federal } \\
\text { Okrug }\end{array}$ & 14.5 & 8.7 & 466 \\
\hline Russian Federation & 6.7 & 4.2 & 398 \\
\hline
\end{tabular}

However, the "pin-pointed" character itself is the main object of criticism, since bankruptcy procedures are oriented toward large, potentially efficient enterprises. Besides, the intensity "span" across Russian regions is very variable (and is still becoming wider). Just note the following estimates: as of 1 January 2001, the number of bankruptcy cases per 1000 enterprises in Moscow was 0.92, in St. Petersburg 0.85 , while in the Republic of Altai - 65.9, and in the Republic of Sakha (Yakutia) - 53.1. Thus, in some Russian regions, the scope of bankruptcy can be considerable.

Now let us consider the results of applying different bankruptcy procedures to debtors.

The main trend in applying the procedure of observation is that of a growing percentage of the decisions concerning initiation of the proceedings in bankruptcy (especially in 2002) and a decline in the number of those concerning the imposition of external administration. On the whole, as seen by the results of 2002 , only about $5 \%$ of enterprises 
"came out of bankruptcy" in the course of the observation procedure, $10 \%$ - became subject to the reorganization procedure (external administration), while almost $80 \%$ entered the phase of bankruptcy proceedings (sale of property and liquidation of the business).

Table 9

\section{Results of applying supervision procedure}

\begin{tabular}{|c|c|c|c|c|c|}
\hline \multirow{2}{*}{$\begin{array}{l}\text { Main variants of decisions, by } \\
\text { results of effectuating supervi- } \\
\text { sion procedure }\end{array}$} & \multicolumn{5}{|c|}{$\begin{array}{l}\text { Number of decisions in respect to specific } \\
\text { variant, as \% of total number of decisions }\end{array}$} \\
\hline & 1998 & 1999 & 2000 & 2001 & 2002 \\
\hline $\begin{array}{l}\text { Initiation of bankruptcy proceed- } \\
\text { ings }\end{array}$ & 59.3 & 60.4 & 66.7 & 73.2 & 79.1 \\
\hline $\begin{array}{l}\text { Imposition of external admini- } \\
\text { stration }\end{array}$ & 21.8 & 17.9 & 13.9 & 13.2 & 10.1 \\
\hline $\begin{array}{l}\text { Termination of proceedings due } \\
\text { to approval of amicable settle- } \\
\text { ment }\end{array}$ & 4.7 & 6.3 & 5.1 & 4.2 & 1.6 \\
\hline Termination of proceedings & 8.5 & 9.3 & 9.8 & 5.8 & 3.9 \\
\hline $\begin{array}{l}\text { Refusal to deem debtor to be } \\
\text { bankrupt }\end{array}$ & 4.2 & 4.0 & 3.4 & 3.1 & 2.6 \\
\hline Other & 1.5 & 2.2 & 1.0 & 0.6 & 2.7 \\
\hline $\begin{array}{l}\text { Total number of decisions made } \\
\text { during effectuation of supervi- } \\
\text { sion procedures }\end{array}$ & 3200 & 5938 & 7156 & 8412 & 9224 \\
\hline
\end{tabular}

The results of applying the procedure of external administration appear to be rather controversial. During the period of 1998-2002, every year the procedures of external administration were imposed on 10001200 debtor enterprises (Table 9). Until 2002, the practice of resorting to amicable settlements was gradually becoming more common, but simultaneously the specific weight of the decisions concerning the initiation of bankruptcy proceedings was also growing.

In 2002, rather noticeable negative developments occurred in the effectuation of the procedure of external administration: resulting from such procedures, no more than $10 \%$ of enterprises "came out of bankruptcy" (in 2001 - about 20\%), more than 30\% - remained under this reorganization procedure due to its prolongation, while $60 \%$ transited into the liquidation phase (whereas in 2001 - less than 50\%). Not counting the decisions to the effect of extending external administration, then the "regidity" of this procedure (in terms of making the deci- 
sions concerning a debtor's liquidation) becomes approximately the same as in the case of observation. This is an evidence of a very low efficiency of the procedure of external administration in terms of reorganizing and reforming a debtor's business.

Table 10

Results of applying the procedure of external administration

\begin{tabular}{|c|c|c|c|c|c|}
\hline \multirow{2}{*}{$\begin{array}{l}\text { Main variants of decisions, by re- } \\
\text { sults of effectuating external ad- } \\
\text { ministration procedure }\end{array}$} & \multicolumn{5}{|c|}{$\begin{array}{l}\text { Number of decisions in respect to specific } \\
\text { variant, as \% of total number of decisions }\end{array}$} \\
\hline & 1998 & 1999 & 2000 & 2001 & 2002 \\
\hline Initiation of bankruptcy proceedings & 48.8 & 33.7 & 42.5 & 48.3 & 58.8 \\
\hline $\begin{array}{l}\text { Period of external administration ex- } \\
\text { tended by } 6 \text { months }\end{array}$ & 15.3 & 30.7 & 24.1 & 21.3 & 21.5 \\
\hline $\begin{array}{l}\text { Period of external administration ex- } \\
\text { tended by more than } 6 \text { months }\end{array}$ & 15.6 & 16.3 & 14.8 & 10.8 & 9.6 \\
\hline $\begin{array}{l}\text { Termination of proceedings due to } \\
\text { approval of amicable settlement }\end{array}$ & 6.6 & 12.9 & 13.9 & 16.9 & 7.1 \\
\hline $\begin{array}{l}\text { Termination of proceedings due to } \\
\text { restored solvency }\end{array}$ & 9.9 & 4.3 & 2.3 & 2.7 & 1.2 \\
\hline Termination of proceedings & 3.8 & 2.0 & 2.4 & 0.0 & 1.7 \\
\hline $\begin{array}{l}\text { Total number of decisions made dur- } \\
\text { ing effectuation of external admini- } \\
\text { stration }\end{array}$ & 695 & 1523 & 2135 & 1922 & 1695 \\
\hline
\end{tabular}

In 2002, within the framework of bankruptcy proceedings, only $0.3 \%$ of bankruptcy cases were closed by way of an amicable settlement. Such a low proportion of amicable settlements within the framework of this procedure is largely due to the fact that it is the procedure of bankruptcy proceedings that "receives" the "flow of cases" in respect to absent debtors or debtors being liquidated, which thus bypasses all other procedures. While in 1998-1999 at the "input" of bankruptcy proceedings the ratio between "substantive" debtors to absent debtors was about $1: 1$, in 2000 it became about 1:2, in 2001 - about 1:4, and in $2002-1: 10$.

Even if we disregard those debtors that undergo a simplified bankruptcy procedure, still, according to our gross estimation, bankruptcy proceedings result in an amicable settlement, at most, in 1 or 2 cases out of 100 . 
Results of applying bankruptcy proceedings

\begin{tabular}{|c|c|c|c|c|c|}
\hline \multirow{2}{*}{$\begin{array}{c}\text { Main variants of decisions, by re- } \\
\text { sults of effectuating proceedings in } \\
\text { bankruptcy }\end{array}$} & \multicolumn{5}{|c|}{$\begin{array}{l}\text { Number of decisions in respect to specific } \\
\text { variant, as \% of total number of decisions }\end{array}$} \\
\hline & 1998 & 1999 & 2000 & 2001 & 2002 \\
\hline Bankruptcy proceedings completed & 77.1 & 66.8 & 66.7 & 70.3 & 77.2 \\
\hline $\begin{array}{l}\text { Period of bankruptcy proceedings ex- } \\
\text { tended for } 6 \text { months }\end{array}$ & 12.6 & 23.6 & 22.3 & 21.0 & 16.0 \\
\hline $\begin{array}{l}\text { Period of bankruptcy proceedings ex- } \\
\text { tended for more than } 6 \text { months }\end{array}$ & 7.2 & 8.4 & 10.3 & 8.2 & 6.5 \\
\hline Amicable settlements approved & 3.1 & 1.2 & 0.7 & 0.5 & 0.3 \\
\hline $\begin{array}{l}\text { Total number of decisions made during } \\
\text { effectuation of bankruptcy proceed- } \\
\text { ings, and such proceedings completed }\end{array}$ & 1479 & 5818 & 12325 & 22752 & 51250 \\
\hline
\end{tabular}

When considering on the whole the "outcome" of all bankruptcy procedures, it can be noted that in a vast majority of cases they result in the sale of a debtor's assets in the course of bankruptcy proceedings. Indeed, the visible dramatic rise in the proportion of outcomes in the form of bankruptcy proceedings in the total number of completed bankruptcy cases, once again, is associated mainly with the growth in the number of petitions in bankruptcy in respect to absent debtors. According to the FSFRB, in the first half-year of 2002 , about $90 \%$ of the total number of completed bankruptcy cases resulted in the debtor's liquidation, and $2 / 3$ of the organizations liquidated during that period were $a b-$ sent debtors.

At the same time, within the framework of both the procedure of external administration and, especially, that of supervision, an increase in the proportion of the decisions concerning the initiation of the proceedings in bankruptcy was easily detected. In 2001-2002, there was a trend toward a reduction not only in the percentage, but also in the number of "positive outcomes" of bankruptcy procedures - the termination of proceedings, including as a result of an amicable settlement and restored solvency. Thus, the cause of the rise in the number of decisions concerning the initiation of the proceedings in bankruptcy in respect to "substantive" debtors in 2001, and even more so, in 2002, was not a growing number of petitions, but rather a stronger orientation of the procedures of observation and external administration toward bankruptcy proceedings. 


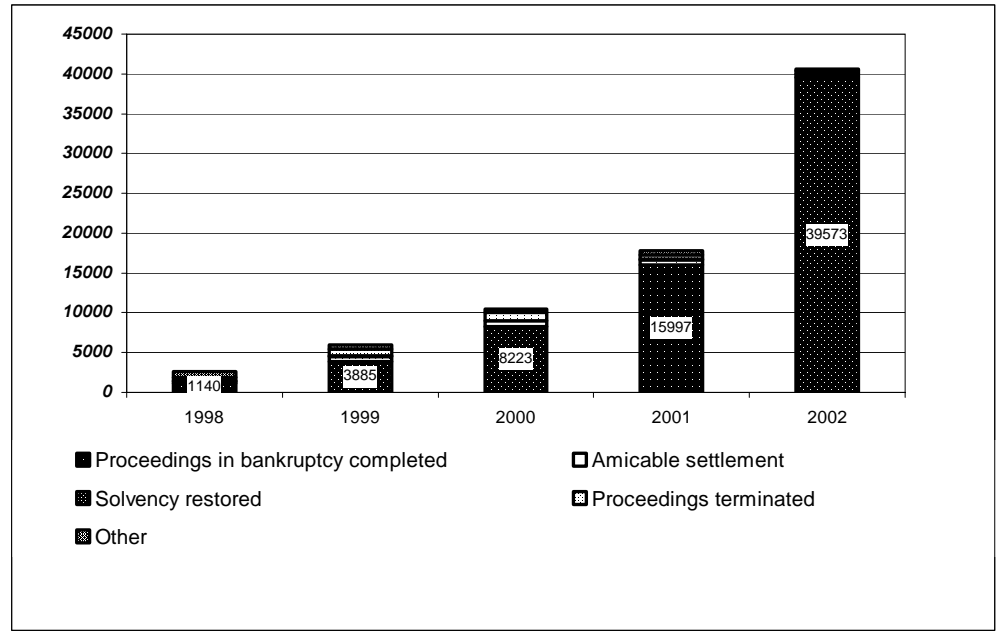

Fig. 4. Estimated "structure of outcomes" in bankruptcy procedures

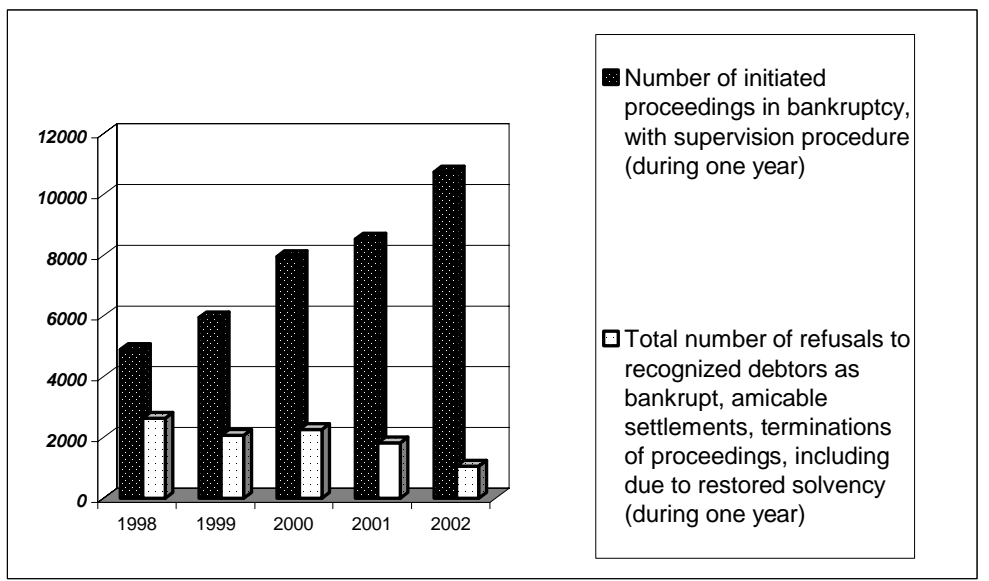

Fig. 5. Ratio between number of "positive outcomes" and number of bankruptcy cases in respect to "substantive" debtors

We believe it important to comment on the substantial dependence of the outcome of bankruptcy on the scope of a debtor's business. Ac- 
cording to our estimations, the larger and more important a business is, the more "sparing" are the bankruptcy procedures being applied to it. Thus, we have found that in 2001 the bankruptcy procedures initiated in respect to large, economically or socially important enterprises resulted in bankruptcy proceedings being initiated approximately in one-fourth of all cases, while in respect to the whole spectrum of "substantive" debtors - in two-thirds.

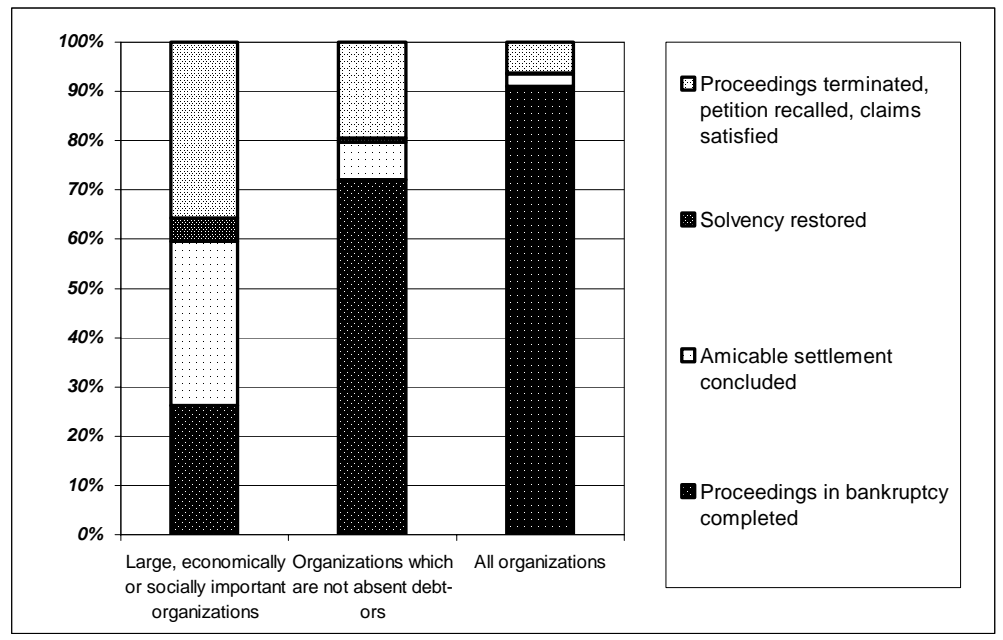

Fig. 6. Comparative estimation of "hardness" of bankruptcy procedures, depending on debtor's importance (2001)

However, two circumstances must be taken in consideration in this connection. Firstly, while, on the average, the processes of bankruptcy involve a negligible portion of economic subjects, in respect to large enterprises their scope is much wider (in 1998-2001, a total of 359 petitions in bankruptcy were filed against enterprises forming company towns). Secondly, even if a bankruptcy case involving a large enterprise does not culminate in bankruptcy proceedings, the business suffers substantial losses during the struggle for corporate control and/or asset withdrawal in the process of external administration (the period of which can be quite lengthy). 
Generally speaking, bankruptcy procedures have demonstrated not only their very low efficiency in terms of business restructuring, but also a rather low potential for debt repayment to creditors ${ }^{155}$. As seen by the results of the first half-year of 2001 , the fourth-priority creditors (in respect to arrears of mandatory payments to the State), as a result of bankruptcy procedures, received only $7 \%$ of the total amount of their claims, while the fifth-priority creditors (debts to creditors in bankruptcy) - about $4 \%$ of their claims, these figures varying greatly from region to region. By the end of 2001, as estimated by the FSFRB, the degree of debt repayment to the State rose to $31 \%$ and to $24 \%$ - to creditors in bankruptcy; however, in the first half-year of 2002 the index of stale debt repayment as a result of applying bankruptcy procedures, once again, declined to $15-17 \%$.

To reckon up our analysis, it seems necessary to pay attention to the following trends in the application of bankruptcy procedures in $2002^{156}$.

In 2002, a dynamic growth in the number of initiated bankruptcy cases continued - during that year, a total of about 95,000 petitions were filed, as compared to about 48,000 in 2001 . This growth was largely due to the suits against absent debtors. The proportion of cases involving absent debtors in the total number of accepted petitions in bankruptcy against debtors in 2002 grew to approximately $85 \%$. At the same time, the number of initiated bankruptcy procedures in respect to real enterprises did not change to a significant degree and amounted in 2002 , according to our estimations, to no more than 7500 .

The load on the judicial system grew considerably as a result of a rapid growth in the number of bankruptcy cases being considered - as

\footnotetext{
${ }^{155}$ Generally speaking, this is characteristic not only of Russia. Risk predictability for creditors at the macrolevel is ensured primarily by both the liquidation of defaulters and their timely petitioning to the court when they are incapable of fulfilling their obligations, and not by a high level of debt repayment.

${ }^{156}$ See also: Simachiov Yu. (2003), Institut nesostoiiatel'nosti v Rossii: spros, osnovnye tendentsii i problemy razvitiia (The institute of insolvensy in Russia: demand, main trends and problems of development). - In: Voprosy ekonomiki. 2003, No. 4; Golikova V., T. Dolgopyatova, B. Kuznetsov, Yu. Simachiov (2003). Spros na pravo v oblasti korporativnogo upravleniia: empiricheskiie svidetelstva (The demand for law in the field of corporate governance: empiric strategies). Series "Nauchnye doklady: nezavisimyi ekonomicheskii analiz" (Scientific reports: Independent economic analysis) In: No. 148. M.: Moscow Public Science Foundation. ANO "Proekty dlia budushchego: nauchnye i obrazovatel'nye tehknologii" (Projects for the future: science and education technologies), 2003.
} 
of 1 January 2003, almost 103,000 cases were uncompleted (as compared to about 53,000 as of 1 January 2002).

In 2002, there was a noticeable growth in the number of petitions filed by creditors. This occurred largely due to the expected adoption of the new 3rd Law on bankruptcy, which was to significantly limit the possibilities for initiating bankruptcy procedures.

The moderate growth in the number of petitions filed by debtors in 2002 in accordance with Article 8 of the $2^{\text {nd }}$ Law on bankruptcy was associated, among other things, with the desire to complete the procedures of fictitious and premeditated bankruptcy (including those with the purpose to avoid taxation) while the old Law was in force.

There was a stronger tendency toward a reduction not only in the percentage, but also in the number of "positive outcomes" of bankruptcy procedures (such as the termination of proceedings, including due to an amicable settlement and restored solvency). Thus, the growth in the number of decisions concerning the initiation of bankruptcy proceedings against "substantive" debtors resulted not so much from a greater number of petitions to this effect, but rather from a stronger orientation of the procedures of observation and external administration toward "bankruptcy proceedings".

\subsection{The $3^{\text {rd }}$ Law on bankruptcy: the first results of its application in 2003}

Judging by the results of applying bankruptcy procedures in 2003, some preliminary comments may be offered concerning the problems that have arisen in connection with the implementation of the new $\left(3^{\text {rd }}\right)$ Law on bankruptcy. Certainly, it can be argued that due to the absence of a well-established judicial practice of applying the $3^{\text {rd }}$ Law's provisions, its potential has not yet been fully realized; but nevertheless, we may still make judgments as to its most obvious limitations, both in terms of the estimated situation in the sphere of applying bankruptcy procedures and of the existing flaws in the norms established by this Law.

In 2003, the scope of applying bankruptcy procedures was markedly reduced: the number of petitions in bankruptcy against debtors went down by 7.5 times - from 10,6647 in 2002 to 14,277 in 2003; the 
reduction in the number of accepted petitions was even more dramatic by 9.8 times, from 94,531 in 2002 to 9,695 in 2003.

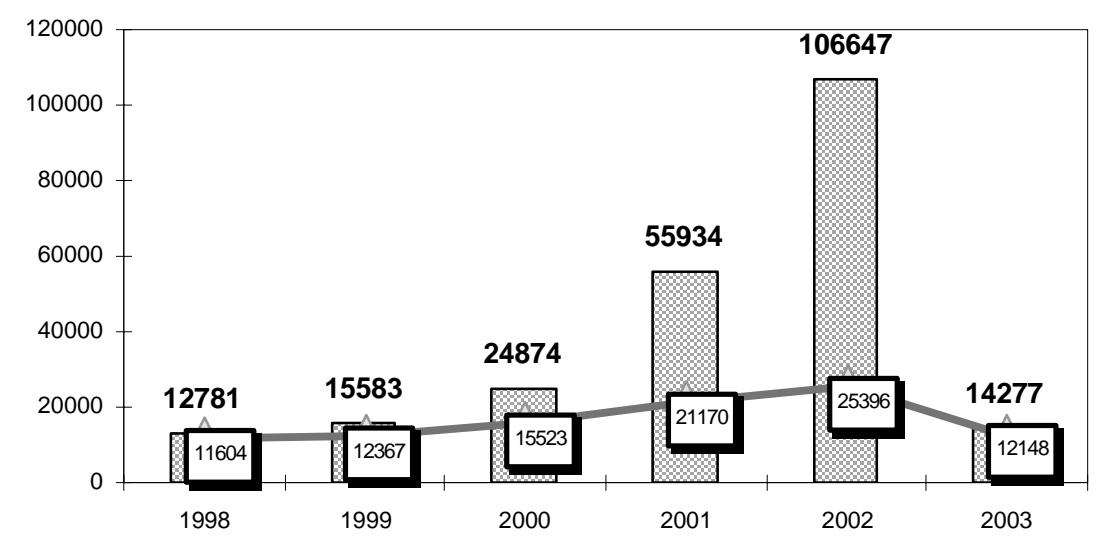

Total number of petitions $\longrightarrow$ Total number of petitions, without those filed in respect to absent debtors

Fig. 7. Changes in the number of petitions in bankruptcy

This dramatic reduction in the number of petitions filed was caused, in about $85 \%$ of cases, by the fact that the tax authorities were actually no more petitioning against absent debtors - in 2003, only 2129 petitions in respect to absent debtors were filed, against 81251 in 2002. Such was the "effect" of the norms of the $3^{\text {rd }}$ Law on bankruptcy stipulating that bankruptcy procedures be applied to absent debtors only when appropriate funds are available in the budget; however, as expected, in the 2003 budget there were no allocations for this purpose.

On the whole, the result was positive, because the system of arbitrage courts was relieved of an unreasonable burden; however, the problem of absent debtors has not yet been resolved by legislative means other than bankruptcy. Therefore, the leadership of the RF Supreme Arbitrage Court feel rather pessimistic about the nearest future, expecting that liquidation procedures might be soon renewed in re- 
spect to approximately 1.5 million actually absent enterprises and organizations through applying simplified bankruptcy procedures ${ }^{157}$.

Against the background of large-scale reduction in the number of petitions filed in respect to absent debtors, a similar reduction in respect to "substantive" debtors does not seem so significant; however, in actuality the number of such petitions dropped by approximately one-half. The number of accepted petitions, with supervision imposed, was 5351 in 2003, as compared to 10739 in 2002. This, obviously, was the result of toughened conditions for filing the petitions in bankruptcy: the norms of the $3^{\text {rd }}$ Law on bankruptcy determine that the initiation of bankruptcy procedures on a creditor's petition can be possible only after the latter has produced a writ of execution stating that the creditor has attempted to ensure debt repayment within the framework of execution proceedings. However, most probably, this effect is going to be short-lived - it is just possible that many creditors have not yet had time to "pass" their debtors through execution proceedings.

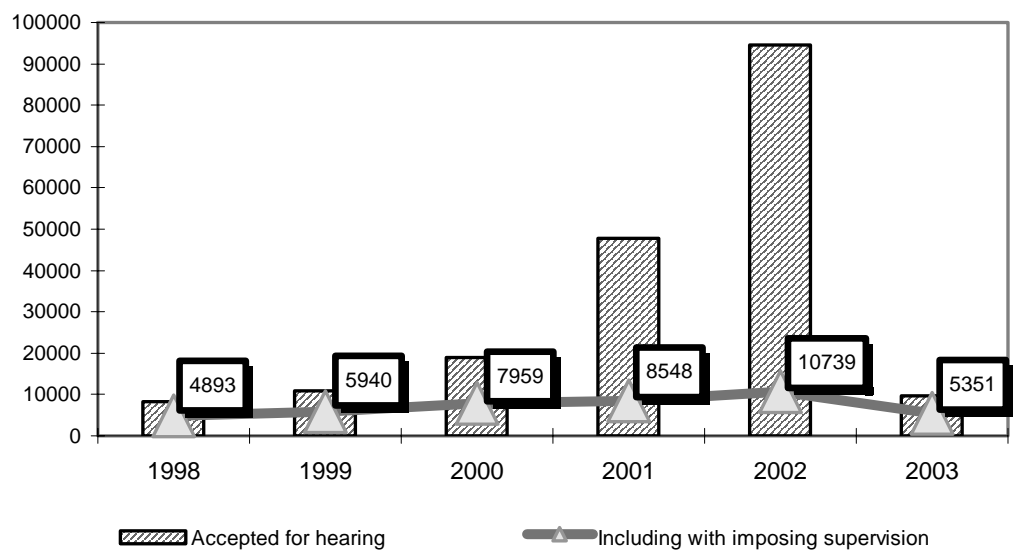

Fig. 8. Changes in the number of petitions in bankruptcy accepted for hearing

\footnotetext{
${ }^{157}$ Yakovlev V. F. Itogi raboty arbitrazhnykh sudov v 2003 g. Osnovnye zadachi na $2004 \mathrm{~g}$. (Results of the activity of arbitrage courts in 2003. Main goals for 2004.) Minutes of the conference of chairpersons of arbitrage courts of the Russian Federation. (11 February 2004).
} 
At a first glance, the more dramatic reduction in the number of accepted petitions in bankruptcy, as compared to the number of petitions filed, may be interpreted in terms of a higher "level of demands" to the petitions on the part of the courts. However, the growth in the number of accepted petitions witnessed in 1999-2002 was associated with a higher proportion of the number of petitions filed in respect to absent debtors, and so in 2003, while the initiation of simplified bankruptcy procedures was becoming markedly less active, the percentage of rejected petitions became higher.

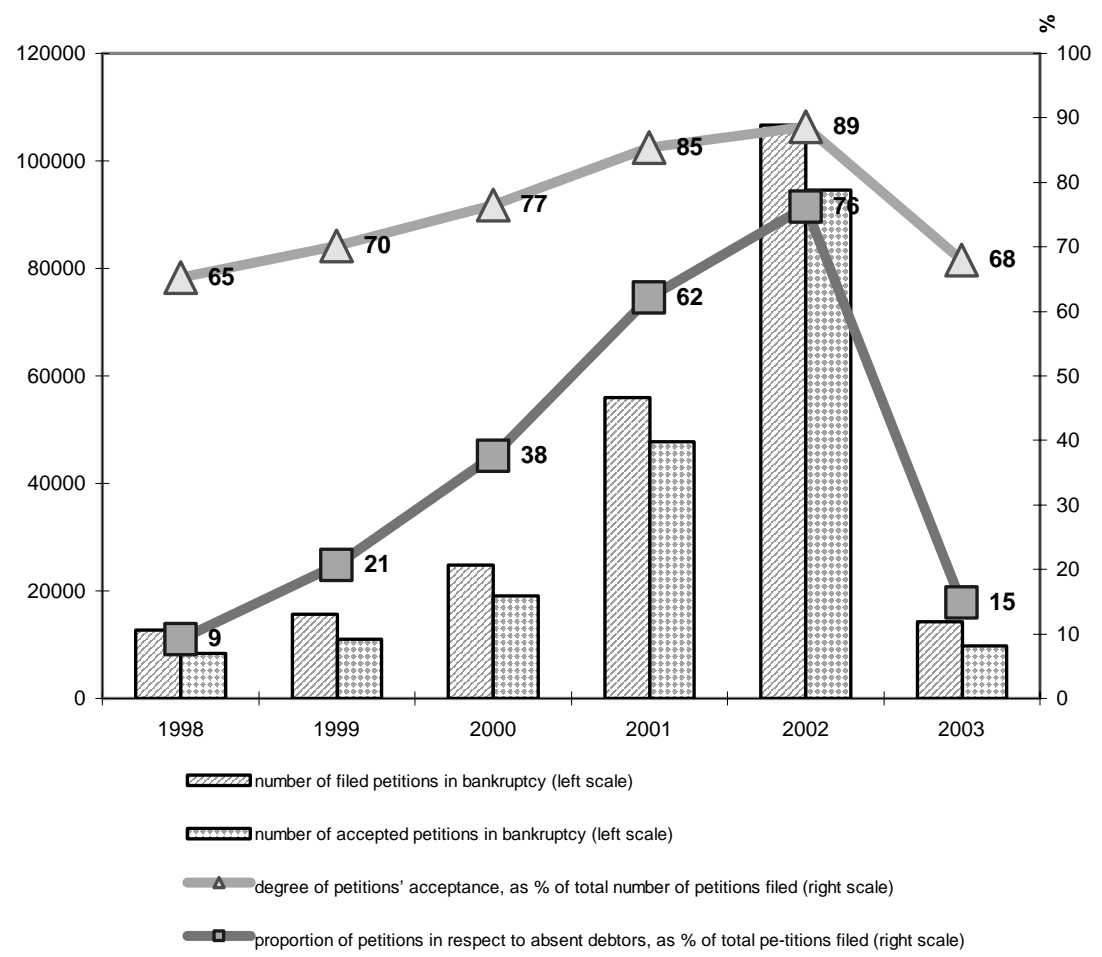

Fig. 9. Level of acceptability of petitions in bankruptcy

On the whole, the "exclusive character" of the application of bankruptcy procedures became markedly stronger, and its external aspect 
(by the number of petitions filed, the percentage therein of suits against absent debtors), in 2003, resembles, in terms of scope, the situation typical of 1998-1999.

The Law on bankruptcy continues to "compete", rather successfully, with the Law on privatization as regards the sphere of liquidation of unitary enterprises ${ }^{158}$. Although the number of cases initiated against "substantive" debtors in 2003, as compared to 2002, was reduced by half, the number of state unitary enterprises (SUE) in respect to which it was decided to initiate the proceedings in bankruptcy, did not go down very noticeably - from 643 in 2002 to 511 in 2003. According to the top officials of the Federal Agency for Managing Federal Property ${ }^{159}$, as soon as a plan emerges that a certain SUE is to become a joint-stock company, its assets are dispersed, and it is made bankrupt, as a rule, by its own CEOs.

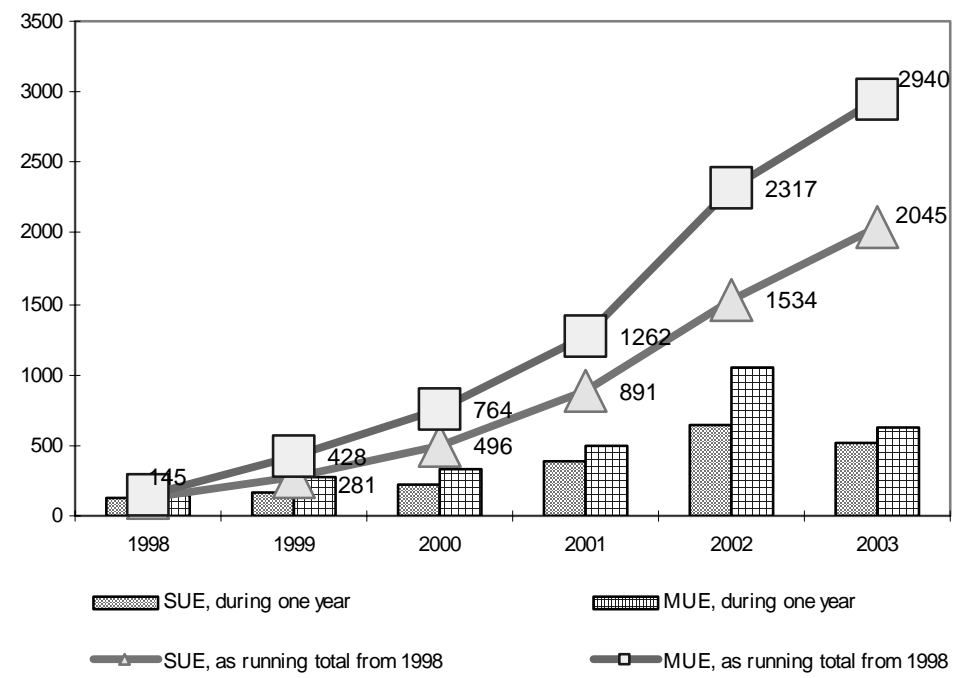

Fig. 10. Changes in the number of bankruptcy proceedings in respect to unitary enterprises

\footnotetext{
${ }^{158}$ In 2000-2003, about 500 federal state unitary enterprises were privatized.

${ }^{159}$ An interview with Valerii Nazarov, Head of the Federal Agency for Managing Federal Property. - Vedomosti, 18 May 2004.
} 
The practice of applying the 3rd Law on bankruptcy in 2003 does not make it possible to speak of any positive changes in respect to the solutions to problems associated with reorganization and rehabilitation of enterprises in the course of bankruptcy procedures.

Approximately in $70 \%$ the supervision procedures culminated in the initiation of bankruptcy proceedings. The trend toward a reduction in both the number and the percentage of the decisions concerning the imposition of external administration was still visible (547 in 2003, as compared to 931 in 2002). The number of approved amicable settlements went down remarkably: from 145 in 2002 to 54 in 2003.

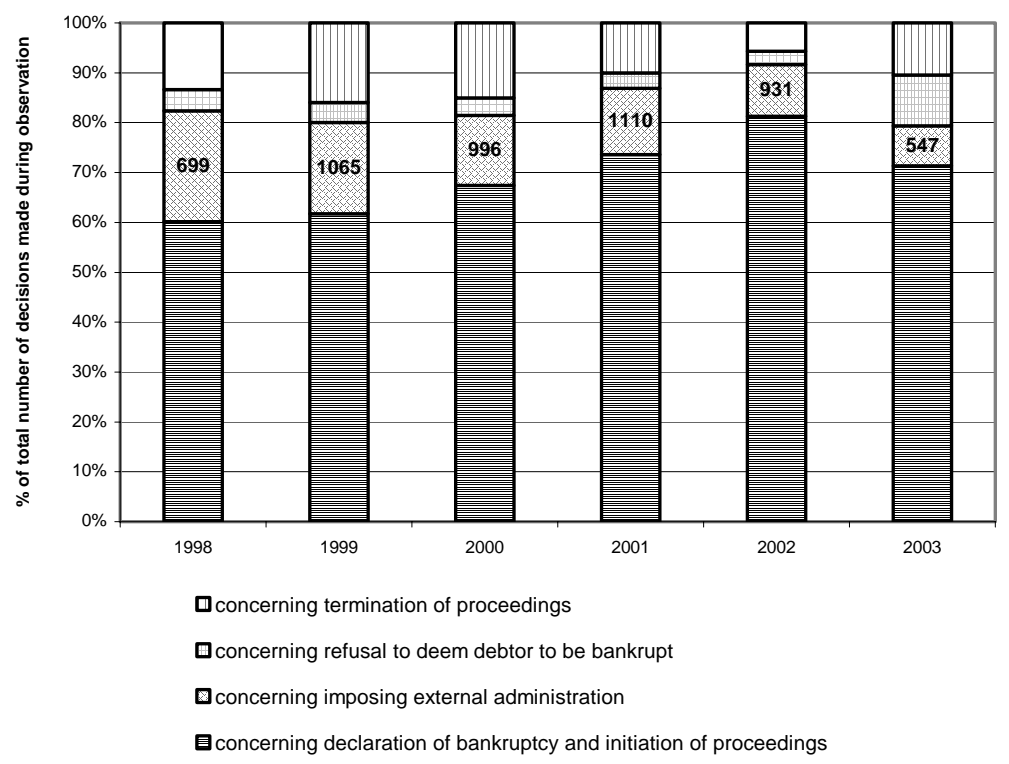

Fig. 11. Supervision: structure of decisions

At the same time, the percentage of refusals to recognize a debtor as bankrupt, as well as that of the decisions that the proceedings be terminated, became much greater, being an evidence of a higher role being played by arbitrage courts in protecting the interests of potentially solvent enterprises. Only due to these factors the general orientation of supervision procedures toward bankruptcy proceedings became somewhat more limited. 
The procedures of external administration were even less suitable for either amicable settlements or for the restoration of enterprises' solvency. In more than $90 \%$ of cases considered in the year 2003 , the procedures of external administration culminated in decisions to initiate bankruptcy proceedings. The trend toward a reduction in the number of amicable settlements was maintained (53 in 2003, as compared to 121 in 2002), while solvency was restored only rarely (in 28 cases).

On the whole, considering all their "phases", bankruptcy procedures in 2003 resulted in the rehabilitation of a debtor's business in approximately 230 cases: in 170, the proceedings were terminated due to amicable settlements, and in 56 - due to restored solvency and satisfaction of the creditors' claims.

Thus, despite the expanded mechanisms for preserving debtors' businesses (the 3rd Law on bankruptcy envisages, in particular, the possibilities for returning from bankruptcy proceedings to external administration, when there exists genuine chances to restore solvency, or for an additional issue of shares being carried out in the course of external administration with the consent of a debtor's owner), one may hardly speak of any positive changes. The practice of applying bankruptcy procedures in 2003 has shown that there is still a trend (even somewhat enhanced) of the orientation of bankruptcy procedures toward the actual bankruptcy proceedings.

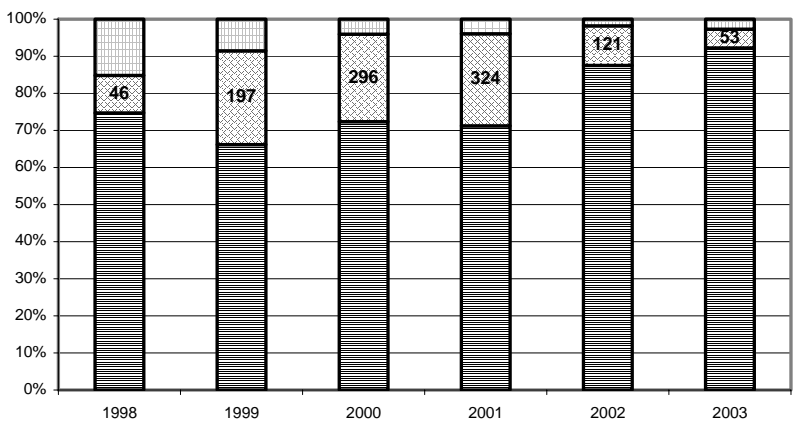

口proceedings terminated due to restored solvency

口proceedings terminated due to approval of amicable settlement

目decision made that debtor be deemed to be bankrupt and proceedings in bankruptcy be in

Fig. 12. External administration: structure of decisions 
When the norms established by the 3rd Law on bankruptcy were being elaborated, the owners' motivations for reorganizing and developing their indebted businesses were obviously overestimated. It was assumed that a considerable percentage of bankruptcies are not completed "peacefully" only because the owners had no opportunities for repaying the enterprises' debts and rehabilitate them. Therefore, the 3rd Law on bankruptcy has introduced, as participants in the process, the owners of a debtor enterprise. Besides, the Law has determined the right of a debtor enterprise, its owners and any third parties, at any stage, with the consent of the bankruptcy commissioner, to terminate the bankruptcy procedure by repaying the enterprise's debts. The Law has established a new reorganization procedure - financial recovery, which, as thought, was to make it possible, under certain conditions, for the debtor's founders (or participants) to keep control over the enterprise's destiny even in a situation of initiated bankruptcy procedures.

However, in fact, all these innovations were really in small demand. The procedure of financial recovery was introduced only in 10 cases. The procedures of external administration only in 28 cases were terminated by satisfying the creditors' claims. Only in 19 cases there was a transition from bankruptcy proceedings to external administration.

In our opinion, the practice of applying the 3rd Law on bankruptcy in 2003 has demonstrated the wrongness of the postulate (actively discussed in 2001-2002) that within the framework of bankruptcy procedures there occurs mass-scale violation of the rights of debtors and their owners who in the course of the implementation of bankruptcy procedures are being "prevented" from rehabilitating their enterprise and repaying its debts.

In 2003, there was sharp rise in the number of applications and complaints within the framework of bankruptcy cases, and the level of "disputability" of these cases also became higher, this being the consequence not only of the "novelty" of the Law on bankruptcy. The norms established by the 3rd Law on bankruptcy have considerably expanded the opportunities for bringing protests during bankruptcy proceedings for example, the right for an owners' representative to protest in the court against creditors' claims was introduced, as well as the possibility for appealing against the rulings made during bankruptcy procedures in 
respect to disagreements between the persons participating in the case.
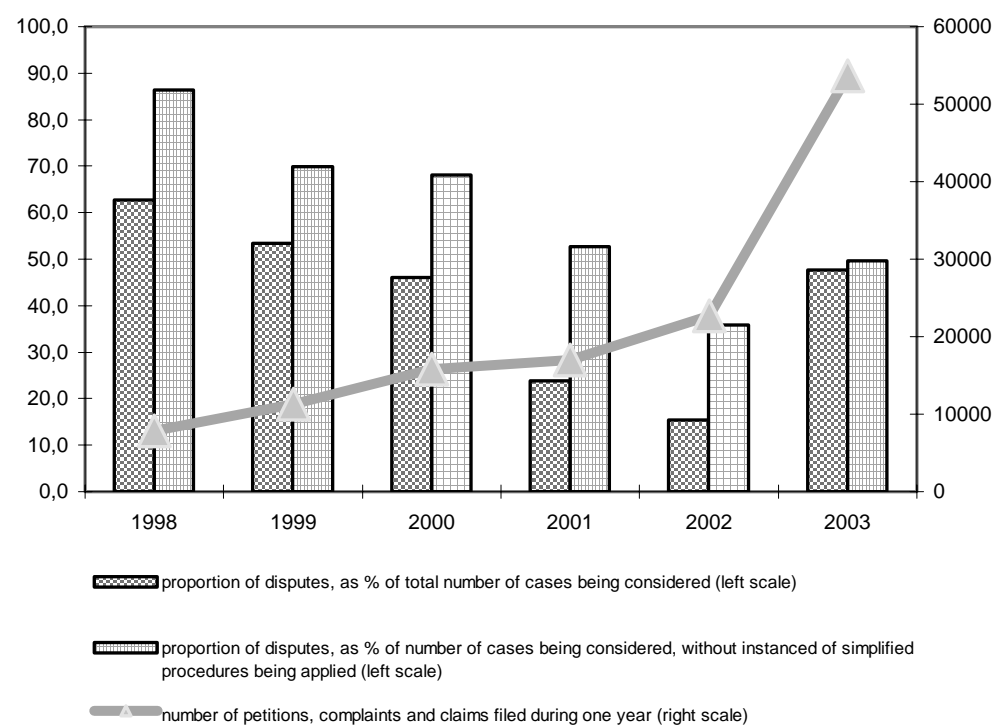

Fig. 13. Estimated disputability level of bankruptcy procedures

At the same time, it should be noted that among all the applications and complaints filed within the framework of bankruptcy procedures being applied to organizations in 2003 , more than $60 \%$ were relating to the determination of the amounts of creditors' claims. Thus, despite its declared intentions, the 3rd Law on bankruptcy has left open rather extensive opportunities for different interpretations of the principles for determining creditors' claims.

In conclusion, we believe it important to offer in this section the general estimates of the influence of the institution of insolvency on the demography of organizations ${ }^{160}$. In the period from 1 July 2002 to 1 July 2004 , a total of about 145,000 organizations terminated their activity, while at the same time almost 600,000 were created anew. In $77 \%$ of

${ }^{160}$ The estimations were based on the RF MTL's data concerning State registration of Russia's juridical persons in the Single State Register of Juridical Persons. 
cases, the termination of the activity of juridical persons during that period was due to their liquidation, and only in $20 \%$ of cases to their reorganization.

The liquidation of organizations in the majority of cases $(72 \%$ of the total) was associated with the application of bankruptcy procedures. On the whole, bankruptcy procedures during the two years resulted in the liquidation of $4.7 \%$ of all organizations as of 1 July 2002.

The importance of bankruptcy procedures for the liquidation of organizations varies considerably depending on their organizational and legal forms: there processes were more actively developing among industrial cooperatives and joint-stock companies.

\section{Number of bankruptcy procedures}

Table 12

\begin{tabular}{|c|c|c|c|c|}
\hline & \multicolumn{2}{|c|}{$\begin{array}{l}\text { Number of juridical } \\
\text { persons liquidated } \\
\text { in bankruptcy } \\
\text { procedures during period: }\end{array}$} & \multicolumn{2}{|c|}{$\begin{array}{c}\text { Proportion of organizations } \\
\text { liquidated in bankruptcy } \\
\text { procedures, } \\
\text { as percentages in total } \\
\text { number of organizations, } \\
\text { as of beginning of period: }\end{array}$} \\
\hline & $\begin{array}{l}1 \text { July } 2002- \\
30 \text { September } \\
2003 \\
\end{array}$ & $\begin{array}{c}1 \text { October } 2003- \\
1 \text { July } 2004\end{array}$ & $\begin{array}{c}1 \text { July } 2002- \\
30 \text { September } \\
2003\end{array}$ & $\begin{array}{l}1 \text { October } \\
2003- \\
1 \text { July } 2004\end{array}$ \\
\hline $\begin{array}{l}\text { All juridical per- } \\
\text { sons }\end{array}$ & 47531 & 32729 & 2.8 & 1.6 \\
\hline $\begin{array}{l}\text { Limited respon- } \\
\text { sibility and addi- } \\
\text { tional responsi- } \\
\text { bility societies }\end{array}$ & 14035 & 9575 & 1.6 & 0.8 \\
\hline $\begin{array}{l}\text { Joint-stock so- } \\
\text { cieties (closed, } \\
\text { open) }\end{array}$ & 3760 & 3223 & 2.5 & 1.9 \\
\hline $\begin{array}{l}\text { Industrial coop- } \\
\text { eratives }\end{array}$ & 1346 & 1302 & 5.5 & 5.1 \\
\hline $\begin{array}{l}\text { Unitary enter- } \\
\text { prises }\end{array}$ & 241 & 228 & 1.7 & 1.4 \\
\hline
\end{tabular}

The lowered relevance of bankruptcy procedures for the liquidation of organizations in the period between 1 October 2003 and 1 July 2004 was due both to the shorter period of observation and to the fact that this period (in contrast to the previous one) fully corresponds to that 
after the coming in force of the 3rd Law on bankruptcy, and so fully reflects the dramatic limiting of the practice of filing petitions against absent debtors. It can be noted that this reduction of the role of bankruptcy procedures in the liquidation of enterprises was not uniform throughout the categories of juridical persons. In depended on their organizational-legal form: the decrease in the intensity of applying bankruptcy procedures became most relevant for limited responsibility societies (among which the number of "abandoned" and "fly-by-night" companies is the greatest), and least relevant for industrial cooperatives and unitary enterprises. 


\section{Chapter 5. The practice of applying bankruptcy procedures for control takeover and property redistribution}

This section deals with important "applied" aspects of the institution of bankruptcy consisting in the use of the procedures involved as a method for "low-cost hostile takeover" of a debtor, or, on the contrary, as an instrument for hiding a debtor's assets from the creditor and creditor's claims.

\subsection{8 - late 2002}

According to some authors ${ }^{161}$, during the period of the 2nd Law on bankruptcy being in force, bankruptcy became the type of business activity whose main purpose was the redistribution of ownership rights and of the control over enterprises. Moreover, in Russia some powerful groups emerged, which specialized in this specific business. As a rule, the core of such a group was constituted by lawyers with an in-depth knowledge of the nuances of bankruptcy legislations. Quite often, such groups were joined by former judges and officials from lawenforcement agencies and other state structures directly related to economic regulation.

A sufficiently powerful group could have its own sources of financing; however, most often the necessary funds were provided by a client. The primary goal of such a group was to look for a "victim" enterprise and for potential clients who would order its bankruptcy. As a potential "victim", a company owning attractive real estate or other valuable or liquid assets was usually chosen. Its real solvency, in this connection, was not a relevant factor, because the economic situation faced by a majority of Russian enterprises was quire often uneasy, and it was not difficult to find stale debts among the "victim's" liabilities.

\footnotetext{
${ }^{161}$ See, e.g., Volkov A., Gurova T., Titov V. Sanitary i marodiory (Orderlies and marauders). Ekspert (Expert), No 8 of 1.03.1999; Butrin D. Neupravliiaemyi upravliiaushchii (Unmanageable manager). - Den'gi (Money), No 32 of 16.08.2000; Chernigovskii M. Bankrotstvo zakazyvali? (Have you ordered bankruptcy?). - Kommersant No 103/P of 18.06.2001, etc.
} 
Having unearthed the necessary debts, the group usually bought them out in the form of a bill of exchange (assignment of right of demand). Such an agreement is convenient in that it does not require a debtor's consent for the right of demand being assigned to another person - just a notification is sufficient. However, the very fact of assigning debt to an unrelated person could give rise to the debtor's suspicions and induce the company in question to resort to certain measures in order to repay the debt. Therefore, instead of the notification as required by the law, the company which have bought out the debt quite often would send to the debtor, in a registered letter, some advertising materials or just a blank sheet of paper. Then, in a similar manner, a claim for the payment of the debt would be sent to the debtor. Later, postal receipts and copies of the documents presumably contained in the letters thus mailed served as important evidence in the course of a court trial ${ }^{162}$.

The key role in "bankruptcy business" was to be played by arbitrage managers - temporary and external administrators, and receivers. A temporary administrator, appointed by an arbitrage court simultaneously with introducing the supervision procedure, among other things, was to check whether the attempt to effectuate bankruptcy had not been a premeditated one. However, in actual practice the administrators would often ignore even the most obvious indicia of premeditated bankruptcy.

Supervision was introduced at the Joint-Stock Company "Plastpolimer" as a result of a suit brought by the Closed Joint-Stock Company "Firma RDK" and the Closed Joint-Stock Company "UPTK "Khimprom". The temporary administrator appointed by the court, P. Panasenko, did not find out any indicia of premeditated bankruptcy. However, as it was revealed later, "Firma RDK" and "UPTK "Khimprom" had simply given incorrect bank requisites for the payment for their supplies, and so it was, in effect, impossible to repay the debt.

One of the main tasks for a temporary administrator was to form a register of the creditors in bankruptcy. In this connection, the administrator actually was determining the number of votes assigned to each creditor at a creditors' meeting. At this stage, the administrators quite often resorted to various violations and machinations.

${ }^{162}$ Chernigovskii M., ibid. 
The temporary administrator of the Joint-Stock Company "Kuzbassenergo", V. Zubkov, incorrectly stated the amount of credit indebtedness of the Joint-Stock Company to the Russian Joint-Stock Company "UES of Russia" as being 432 million roubles, instead of 1202 million roubles, and a month later increased its total debt from 2.9 billion roubles to 5 billion roubles. Resulting from these actions of the administrator, the share of "UES of Russia" at the creditors' meeting was artificially diminished approximately fivefold ${ }^{163}$.

A temporary commissioner had no full control over an enterprise the powers were limited to observation and analysis of the debtor's solvency status. However, if the administrator succeeded in proving that an enterprise's CEOs had set obstacles to his activity, these CEOs could be dismissed by the arbitrage court. Quire often the CEOs were, indeed, opposed to the interference of the temporary administrator. But even in absence of any opposition on their part, the administrator could simply fabricate appropriate evidence. Thus, instances have become known when, on the demand of temporary administrators, all accounting documentation was transferred to them, including the list of creditors. And after a certain period of time, the enterprise's CEOs would receive the request that the same documents be transferred once again. As a result, if no transfer act had been drawn up in confirmation of the temporary administrator having received such documents, the CEOs could not provide to the court an evidence that the demands of the administrator had already been satisfied, and therefore were dismissed from managing the enterprise ${ }^{164}$.

In the event of CEOs' dismissal, the temporary administrator would become a fully-fledged master of the enterprise. In this connection, the managerial costs of the activity of the administrator and of his "team" were to be covered by the enterprise as a first priority. Taking advantage of this circumstance, the administrators quite often would "blow up" their expenditures, including therein, for example, the cost of trips to foreign shareholders, or even of the redecoration of their own office. There were instances when, in order to provide funding for these expenditures, an administrator would sell the supervised enterprise's equipment and whole workshops.

\footnotetext{
${ }^{163}$ Butrin D. Neupravliiaemyi upravliiaushchii.

${ }^{164}$ Chernigovskii M. Bankrotstvo zakazyvali ?
} 
It should be noted that the owners of enterprises did find, early enough, the ways and instruments for minimizing bankruptcy's negative effects (including those of "orchestrated bankruptcies). Among these instruments, the main one became the so-called "debt pillow" - an artificially formed (as a rule) indebtedness of the enterprise to "related" companies (that is, affiliated to the shareholders and CEOs), the amount of which was very impressive, as compared to all its other debts. This "pillow", in fact, enabled an enterprise's owners and CEOs to retain control over it even if it had been declared bankrupt. It should be noted that in some cases the "debt pillow" was formed after the initiation of bankruptcy procedures, with direct participation of the temporary administrator. And the attempts to form the "pillow" without the latter's knowledge, as a rule, resulted in tragic consequences for the CEOs: the arbitrage courts, at the administrator's request, dismissed all the CEOs from managing the enterprise ${ }^{165}$.

The first creditors' meeting was empowered to replace a temporary administrator by an external one, whose candidacy was to be approved by the arbitrage court on the basis of the minutes of the first creditors' meeting. And the keeping of the minutes was not supervised by anybody - the temporary administrator was the sole one responsible for it. This circumstance enabled the temporary administrator and the arbitrage court to "pass" the candidates for the post of a temporary administrator, in fact disregarding the creditors' opinion.

The autumn of 1998. The European Shipping Company is becoming bankrupt. There are two creditors - a certain investment company and the State (in respect to taxes). The investment company is the initiator of bankruptcy procedings, and in its petition to the arbitrage court it points out its candidate for the position of a temporary administrator. This candidate is for some reason rejected, and the arbitrage court appoints another administrator. The latter calls and holds the first creditors' meeting, during which, in accordance with the law, keeps minutes. The creditors agree in their opinions as to the candidate for the post of an external administrator, but the temporary administrator does not enter his name in the minutes. So what does the judge do in this case? The judge looks into the minutes ... and appoints this same tem-

${ }^{165}$ Butrin D., Neupravliiaemyi upravliiaushchii. 
porary administrator the external administrator. It would be logical to conclude that somebody's order had been thus implemented ${ }^{166}$.

In contrast to a temporary administrator, an external administrator is, in fact, not limited in his powers. It is during external administration that takeovers of enterprises occurred and/or certain actions were committed in order to withdraw assets and thus to avoid the fulfillment of due obligations. For this end, a wide variety of schemes were applied - from the simplest, involving property removal, to rather intricate ones, envisaging the changing of the structure of a debtor's shareholders and the creation of affiliations. It should be noted that some of the schemes were "universal", i.e., could be applied, almost without changes, for taking over a debtor's business or for "protecting" it from creditors. For example, property removal was a "protective" measure, if it was received by structures related to the debtor's owners, and was a form of a business takeover, if the property was being transferred to creditors or their affiliated companies. Other schemes were "unidirectional": for example, the structure of a debtor's shareholders was usually changed for the benefit of some of the creditors, while the formation of affiliations, as a rule, was orientated at maintaining the control of the debtor's founders and CEOs over its most valuable assets. And the key role in implementing each of the schemes was to be played by the external administrator.

Example 1. The Moscow Electro-mechanical Plant No. 1 - a largescale supplier of electro-mechanical systems for specialized products.

November 1, 1997. An external administrator comes to the enterprise - Vladimir Aliabiev, recommended by the Guild of Anti-Crisis Managers, whose Head is Grigorii Yun. On the same day (!) he replaces the security staff at the enterprise.

November 3. The new security officers confiscate the passes and forbade the employees to enter the enterprise.

November 4. The Director of the Limited Partnership "Luka" is appointed to the post of director of operations, and orders that all supply contacts be rewritten, to make the Limited Partnership "Luka" the sole supplier.

December 11. The Guild's Head, Grigorii Yun, has a meeting with representatives of the enterprise's employees. They are informed that

${ }^{166}$ Volkov A. et al, Sanitary i marodiory. 
no wages will be paid. Money is promised only to those who will become employed by the Limited Partnership "Luka".

December 12-13. The tools from the central tools warehouse and the materials from the operation-material warehouse are being removed.

March 25, 1998. The enterprise, in effect, has terminated its existence. An order concerning the termination of operations is issued. The whole operation has been carried out within five months ${ }^{167}$.

Example 2. Achinsk Aluminous Combine (AAC). In the era of the Soviet Union, the Combine was considered to be the largest alumina producer and supplied aluminum plants with raw material, primarily the Krasnoyarsk plant (KAP). However, the Combine was unable to adjust to the market economy, and at the end of 1996 was, in effect, bankrupt. External administration was imposed, and the administrator's post was given to Gleb Fetisov, who previously had been employed by the "Alpha" Group. At that moment, the interests of the "Alpha" Group and the Krasnoyarsk plant coincided, and so the latter voiced no objections as to this candidate. However, in a year and a half, the CEOs in charge of the KAP were replaced, and by mid-1998 the KAP and "Alpha" were allies no more. In the summer of 1998, five Russian aluminum plants (including the Krasnoyarsk plant) came forth with the initiative to appoint a new person in Achinsk. The Arbitrage Court of Krasnoyarsk Krai gave support to this initiative, and on 30 July the nominee of the aluminum plants, Nail Nasyrov, was appointed external administrator. But when the new external administrator began to execute his responsibilities, he found that during the period when Gleb Fetisov had been in charge, all the AAC's main assets had become property of the companies affiliated to the "Alpha" Group.

The scheme according to which the Combine's property was alienated is somewhat more sophisticated than the one described in Example 1. In early 1997, the Achinsk Aluminous Combine took two loans from the Alpha Bank, in the total amount of 25 billion non-denominated roubles. Simultaneously, the Combine formalized two suretyship contracts with the Open Joint-Stock Company "Alpha-Eko", the main content of which was as follows. "Alpha-Eko" was guaranteeing that it

\footnotetext{
${ }^{167}$ It should be noted that this example occurred in the period during which the 1st Law on bankruptcy was in force.
} 
would be able to repay the loans instead of the AAC, but in that case the fines imposed on the Combine were to amount to 1 per cent per day. The fines became effective since the spring of 1997, after the Open Joint-Stock Company "Alpha-Eko" had repaid to the Alpha Bank the loans granted to the Combine. By February 1998 the Combine's total debt to "Alpha-Eko" had exceeded 100 million denominated roubles, due to which Gleb Fetisov, the bankruptcy commissioner, made the decision to repay the Combine's debt. Between March and May, the Achinsk Aluminous Combine repaid the debt, by transferring to "AlphaEko", in effect, all its main assets in the amount of 75 million roubles, finished products in the amount of 25 million roubles, as well as the right to a five-year lease of the property complex of the Kiia-Shaltyr mine, where the AAC's main raw material, nephelin, was extracted ${ }^{168}$.

Example 3. Leningrad Metallurgical Plant (LMP). The plant's external administrator, Yevgenii Guliaev, by commission of the creditors' council, submitted to the Federal Securities Commission the necessary documents for effectuating an additional issue of shares, without any decision to this effect on the part of shareholders. At the moment of this issue, the LMP was an object of interest for two large business structures: "Energomashinostroitel'naia korporatsia" (Power Machinebuilding Corporation) and "Interros". The former was the plant's main shareholder (32\%), the latter had in control a stake of $16 \%$ and the main bulk of its creditor indebtedness. And this additional issue of shares was to result in the growth of the stake owned by "Interros" to the size of a controlling stake $(51 \%)^{169}$.

Yet another one of the schemes mentioned above is as follows. In the course of external administration, it was found necessary to separate several (the most efficient) operation units into independent enterprises. The parent company (the bankrupt enterprise) established one or several subsidiaries, which it fully owned. Then the decision was made to more than double the subsidiaries' charter capitals. The shares additionally issued in this connection were not transferred to the parent company, but instead, for example, were cross-exchanged between the subsidiaries. As a result, the bankrupt enterprise lost control over its most valuable assets. Later, in the course of bankruptcy pro-

\footnotetext{
${ }^{168}$ Volkov A. et al, Sanitary i marodiory.

${ }^{169}$ Butrin D., Neupravliiaemyi upravliiaushchii.
} 
ceedings, only the non-controlling blocks of the subsidiaries' shares, which remained the enterprise's property, were offered for bidding ${ }^{170}$.

After the period of external administration is over, the external administrator may be replaced by a receiver, whose main task would be to sell the bankrupt enterprise's property. Among the most common abuses committed by receivers we may point out the sale of property at an underestimated price.

Within the framework of bankruptcy proceedings at the Petrozavodsk Aviation Plant, receiver Mikhail Mordashev effectuated the sale of the property, which constituted the mass of the bankrupt's estate, in a "very original" manner. For example, the price of the "Ka-26" helicopters was set at 70,000 roubles (their market price being \$20,000 $50,000)^{171}$.

As for the main "clients" who order bankruptcy procedures in order to take over a business (who are, in effect, the beneficiaries), in many instances there were large business group related to the bankrupt's area of activity. Bankruptcy, in this instance, represented just one of the lower-cost variants of integrating new enterprises and operation units into the target association's structure. During the period when the $2^{\text {nd }}$ Law on bankruptcy was in force, real empires were created, consisting of insolvent plants.

For example, the owners of the "Evroazmetall" Group, in two years, were able to create, by way of imposing external administration on those enterprises that were of interest to them, a very powerful metallurgical alliance, with an annual turnover of about $\$ 2$ billion ${ }^{172}$.

Beside private structures, active participants in "strange" bankruptcies were also regional administrations, striving to redistribute, for their own benefit, the control over their region's enterprises. The established procedures were thus applied by local authorities as a means for taking over the administration of enterprises owned by the federal center or by private investors, as well as an instrument for "protecting" the enterprises, which were (formally and actually) under their control, from unrelated creditors.

\footnotetext{
${ }^{170}$ Volkov A. et al, Sanitary i marodiory.

${ }^{171}$ Butrin D.,Neupravliiaemyi upravliiaushchii.

${ }^{172}$ Butrin D., Neupravliiaemyi upravliiaushchii.
} 
It should be noted that while business structures during the effectuation of orchestrated bankruptcies were relying primarily upon bankruptcy commissioners, local authorities, in addition, could "secure the support" of arbitrage courts, because the latter, as a rule, depended on regional bodies of authority. Of course, under Russian legislation, all arbitrage courts are in federal jurisdiction, and thus cannot be influenced by local administrations. However, in actual practice, due to the insufficiency of federal financing for arbitrage courts and the distance (both political and physical) from the federal center, arbitrage courts are highly dependent upon regional authorities.

The enterprise's CEOs were active allies of regional administrations in the struggle with the federal center and external investors. Regional leaders had an interest in keeping revenues inside their regions and maintaining a high level of employment, CEOs - in maintaining their control over enterprises. The former quite often guaranteed to the latter their protection in exchange for certain "services", like timely payment of all regional taxes, ensuring redundant employment, etc. And in the event of an enterprises bankruptcy being initiated, the governor, through pressure exerted on the arbitrage court, secured the appointment of "the necessary" commissioner (for example, one of the CEOs), who then acted for the governor's benefit ${ }^{173}$.

Concluding our discussion of the period during which the $2^{\text {nd }}$ Law on bankruptcy was in force, we should like to note that despite the massscale character of the abuses and violations of law committed by bankruptcy commissioners, they almost never were brought to serious responsibility for their actions. As a rule, the worst outcome for a bankruptcy commissioner (not counting the possibility of a criminal method of settling the scores with him) was the recalling of a professional license.

This was what the FSFRB did in respect to V. Zubkov, who, in the function of the temporary administrator of the Joint-Stock Company

\footnotetext{
${ }^{173}$ Sonin K., Zhuravskaia Ye. Bankrotstvo v Rossii: ni zashchity kreditorov, ni restrukturirovaniia (Bankruptcy in Russia: neither the protection for creditors, nor restructuring). Spetsial'nyi doklad. Obzor ekonomiki Rossii. Osnovnye tendentsii razvitiia (A special report. An overview of Russia's economy. Main trends of development). 2000. I. Transl. from English. - M., RECEP, 2000.
} 
"Kuzbassenergo", committed large-scale manipulations with debt amounts when forming the register of creditors ${ }^{174}$.

\subsection{Late $\mathbf{2 0 0 2}$ - the present time}

The inefficiency of the $2^{\text {nd }}$ Law on bankruptcy in the part concerning the prevention of "strange" bankruptcies (both of the "takeover" and "protection" types) became one of the main reasons for the elaboration and adoption of the new (third) Federal Law of 26.10.2002 No. 127-FZ "On insolvency (bankruptcy)". More than one and a half years has passed since its coming in force, but disputes thereof are still going on. It should be noted that at first - during the period of its elaboration and in the first few months after its enactment - this Law was regarded very sceptically (if not negatively) by the experts' community. However, even the most militant critics of the new Law remarked that it had a number of advantages, as compared to the federal law previously in force - that of "On insolvency (bankruptcy)" 08.01.1998 No. 6-FZ (hereinafter - the previous law), a more complicated procedure for the initiation of bankruptcy, tougher requirements to bankruptcy commissioners, their withdrawal from the sphere directly influenced by the State, and some oth$\mathrm{ers}^{175}$. However, at the same time, the majority of experts were sharing the viewpoint that despite having certain advantages, however important, the new Law, by the level of its quality, did not differ so much from the previous law, which had been very unsuccessful and imperfect. It was commonly believed that the new Law inherited the main limitation of the previous law - the inability to prevent corruption and violations by the interested parties in the course of the bankruptcy process ${ }^{176}$. In this context, some experts rather negatively estimated one of the principal innovations of the new Law - the requirement that the responsibility of bankruptcy commissioners be insured on a mandatory basis, because they believed that the necessity to seek considerable funds for the

\footnotetext{
${ }^{174}$ Butrin D., Neupravliiaemyi upravliiaushchii.

${ }^{175}$ See, e.g., Rubchenko M. Zachekhlit' ne poluchilos' (No success in covering). - Expert, 17 December 2001;

Fedotkin I., Khomiakov V. Rossiiu triasiot bankrotnaia likhoradka (Russia is being shaken by bankruptcy fever). - Moskovskiie novosti, 23-29 April 2002.

${ }^{176}$ See, e.g , Volkov A., Privalov A. Khudshii zakon Rossii (Russia's worst law)"- 2. - Expert, 4 March 2002.
} 
payment of the insurance premium would inevitably made bankruptcy commissioners dependent on the persons who had provided these funds, and would thus enable the latter to exert pressure on the commissioner and, consequently, to influence the process of bankruptcy.

The main participants in bankruptcy procedures - bankruptcy commissioners and judges - had also their reasons to be displeased with the new Law. Thus, for example, according to A. Yukhnin, member of the directorate of the Russian Association of Independent Experts, a very favorable environment for corruption was created by the stipulation in the new Law to the effect that a candidate for the post of bankruptcy commissioners must have an experience of a CEO, which in effect had "cut off" from this activity the most likely category of candidates young and ambitious managers of junior and medium status ${ }^{177}$. From the point of view of Deputy Chairman of Moscow City Arbitrage Court O. Sviridenko, the new Law did not eliminate the possibility of a transfer of some unique economic objects into the ownership of a limited circle of related persons, while the Law's imperfection in determining the procedure of bidding during the sale of a debtor's property potentially made it possible to obtain, at a very low price, some priceless scientific technologies and unique industrial equipment of any bankrupt enterprise, including a strategic one ${ }^{178}$.

It seems that the only positive estimations of the new Law during that period were offered by those officials who had in some way participated in its elaboration and adoption. Thus, according to V. Pleskachevskii, Chairman of the Committee for Property of the State Duma, the new Law made the whole procedure of bankruptcy more civilized, thus having insured a better equilibrium of the rights of its main participants the debtor and the creditor $^{179}$. In the opinion of Ts. Tserenov, Head of the Department for Regulation of Entrepreneurial Activity and Development of Corporate Governance of the RF Ministry for Economic Devel-

\footnotetext{
${ }^{177}$ Zaiko A. Russkii peredel. Dubl' tri. (Russian repartitition. Take 3). - Kompaniia, 22 April 2002.

${ }^{178}$ Sviridenko O. Naznacheniie i tseli instituta bankrotstva $v$ khoziiaistvennom oborote (Designation and purposes of the institution of bankruptcy in economic turnover). - Pravo i ekonomika, 2003, No. 3.

${ }^{179}$ Pleskachevskii V. "Novyi zakon o bankrotstve ne pozvolit kromsat' predpriiatiie za kopeiki (The new law will not allow to dismember an enterprise for kopecks)". - Biuro pravovoi informatsii (Bureau for legal information), (www.bpi.ru), 19.12.2002.
} 
opment and Trade, within the framework of the new Law, bankruptcy procedures would become more civilized; the market would develop civilized rules; bankruptcy, instead of being applied for property redistribution, would be turned into an instrument for getting rid of inefficient businesses and inefficient types of production ${ }^{180}$. On the whole, the new Law was estimated positively also by the FSFRB's top officials - T. Trefilova, its Director ${ }^{181}$, and First Deputy Director N. Kotsuba ${ }^{182}$.

It should be noted that just like the opponents of the new Law recognized its very substantial advantages, its proponents noted its certain drawbacks. Thus, according to V. Pleskachevskii, the provisions of the new Law determining the role of the State in the process of bankruptcy and the powers of self-regulating organizations needed to be further specified.

By late 2002 - early 2003, the initial, often hasty and disputable opinions of the experts concerning the enacted new Law had given way to more composed and better substantiated estimations ${ }^{183}$. It is noteworthy that the general tone of discussion became "moderately positive" - most experts had recognized the generally progressive charac-

\footnotetext{
${ }^{180}$ Tserenov Ts. "Gosudarstvo stanovitsia real'nym uchastnikom del o bankrotstve (The State is becoming a real participant in bankruptcy cases)". - Expert's Channel, OPEC.RU, 2002.

${ }^{181}$ See, e.g., Neimysheva N., Trefilova T. "Narushat' zakon dolzhno byt' nevygodno (It must be unprofitable to violate the law)". - Vedomosti, 12 August 2002; Kats K. Tatiana Trefilova: Zakon tiazheloi sud'by (A Law with hard luck)". - Gazeta of 14 August 2002; Trefilova T. Vtoroe dykhanie (Second wind). - Ekonomika i zhizn', 2003, No. 11.

${ }^{182}$ Kotsiba N. Voprosy antikrizisnogo upravleniia v usloviiakh deistviia novogo zakona o bankrotstve (Issues of anti-crisis administration under the conditions of the new law on bankruptcy being in force). - Vestnik FSFO RF, 2002, No 10.

${ }^{183}$ See, e.g., Zavadnikov V. Bankrotnye killery lishatsia raboty? (Killers in bankruptcy will lose their jobs?) - Rossiiskaiia gazeta of 2 November 2002; Kiperman G. Novyi zakon o bankrotstve (The new Law on bankruptcy) - Finansovaia gazeta. Regional'nyi vypusk (Regional Issue). 2002, No. 47; Yerofeev A. Bankrotstvo: budet li rabotat' novyi zakon? (Bankruptcy: will the new law work?) - Vedomosti, 27 November 2002; Khudoleev V. Osobennosti poriadka priznaniia nesostoiiatel'nosti (bankrotstva) predpriiatii i organizatsii (The peculioarities of the procedure for recognizing the insolvency (bankruptcy) of enterprises and organizations.- Konsul'tant buhkgaltera, 2003, No. 2; Samodurov V. Vlast' ne proshchaiet dolgi (The State does not forgive debts). An interview with the Director of the FSFRB of Russia Trefilova T. I. - Muzhskaia rabota, 2003, No. 4; V.Vitrianskii. Obzor osnovnykh polozhenii federal'nogo zakona "O nesostoiatel'nosti (bankrotstve)". (An overview of the main provisions of the Federal Law "On insolvency (bankruptcy)" - Antikrizisnoe upravleniie, 2003, No. 5-6.
} 
ter of the new Law. The most positive estimations were offered in respect to the following provisions in the Law:

- a 30-day "period of postponement" was established in the consideration by the arbitrage court of a bankruptcy case, after having accepted a petition that a debtor be deemed to be bankrupt, during which the debtor may repay its debts;

- the formation of the register of the creditors' claims was to be effectuated by a decision of the arbitrage court;

- a new participant was introduced in the bankruptcy process - a representative of the debtor's founders (or participants) or of the owner of the property of a debtor - a unitary enterprise;

- more precisely and in more detail the functions of bankruptcy commissioners were determined;

- it was envisaged that the debtor's opinion be taken into consideration when appointing a bankruptcy commissioner;

- when the debtor's director had been dismissed within the framework of the supervision procedure, his responsibilities were delegated by the arbitrage court to the candidate suggested by the representative of the debtor's founders (or participants) or of the owner of the property of a debtor - a unitary enterprise, and in the event of absence of such a candidate - to one of the deputy directors, or to another employee of the debtor;

- the State was made equal in its rights to the other creditors;

- the election of the creditors' committee was based on cumulative voting;

- a possibility was envisaged for a transition from bankruptcy proceeding to external administration;

- the sale of the debtor's property within the framework of bankruptcy proceeding in a general case was effectuated in an open bidding.

As for the criticism concerning the new Law, an absolute priority belongs to the provision concerning the institution of self-regulating organizations of bankruptcy commissioners (SROs). Some experts have voiced their doubts as to the feasibility of the very idea of creating such an institution. In particular, according to Deputy Chairman of the RF Supreme Arbitrage Court V. Vitrianskii, the activity of SRO "will be aimed only at building the system of a so-called business on debt. If formerly it 
was possible to speak of the engagement of only some of bankruptcy commissioners, now whole organizations with such goals will come into existence. In the West, the policy is oriented to making bankruptcy commissioners more independent, and here it has an opposite orientation. Our attitude to self-regulating organizations is very negative. They are the center of a specific business "on a debtor's bones". It is already known that the main bulk of the debtor's funds will be spent on paying for the services of the organizations accredited to the corresponding self-regulating organizations" ${ }^{184}$.

Other authors, while not rejecting the idea of creating the institution of SRO as such, expressed their strong doubts as to the possibility and advisability of its rapid implementation. In particular, according A. Yerofeev, the manager of "KPMG", "The idea in itself is good and is being widely applied in the world, but in its present form it would hardly bear a good fruit. The transfer of the regulatory functions to SRO, will become possible only when they obtain true force and reputation (instead of simply answering a number of formal criteria). Until this happens, it is better to leave the functions of attestation, observation and sanctions with a state body" 185 .

In addition to "ideological" criticism of the SROs, the experts also made some comments in respect to the specific forms of regulating their activity, which, with a certain generalization, may be boiled down to the following ones:

- insufficient precision of the regulation of the SROs' functions;

- inadequate sufficiency of the mechanisms of supervision over the SROs' activity;

- insufficient precision of the description of the procedure and the conditions for using the compensation fund, etc.

It should be noted that there have also been voiced some positive opinions concerning the SROs. However, these mostly belonged to state officials, who, due to the essence of their work, had been directly involved in the formation and regulation of such organizations (first of

\footnotetext{
${ }^{184}$ Obzor osnovnykh polozhenii federal'nogo zakona "O nesostoiatel'nosti (bankrotstve)". (An overview of the main provisions of the Federal Law "On insolvency (bankruptcy)". Antikrizisnoe upravleniie, 2003, No. 5-6.

${ }^{185}$ Yerofeev A. Bankrotstvo: budet li rabotat' novyi zakon? (Bankruptcy: will the new law work?) - Vedomosti, 27 November 2002.
} 
all, the FSFRB's officials ${ }^{186}$, and so their point of view can hardly be regarded as an objective one.

Beside the problems relating to the regulation, creation and functioning of the SROs, the following features were frequently mentioned as the new Law's limitations:

- the lack of adequate precision in determining the requirements concerning the unrelated status of a bankruptcy commissioner;

- the lifting of the moratorium on certain demands of the creditors;

- the lack of total clarity in respect to the choice of specific bankruptcy procedures, etc.

Finally, quite a few among the innovations introduced by the Law on bankruptcy have been subject to controversial estimations on the part of experts. The most important among these innovations, as well as the typical estimations thereof by the experts (both positive and negative) can be seen in the Table 13:

On the whole, judging by the experts' opinions, it should be recognized that the new Law on bankruptcy, as compared to the previous one, is more progressive. The proof of this is the presence in the new Law of a large number of positive innovations. At the same time, this document is not without its drawbacks, the most significant of which lie in the realm of creation and regulation of SRO.

The enactment of the new Law, just as expected, die not result in a complete elimination of "strange" bankruptcies. Below are some typical examples of the violations and abuses occurring during the period when the new Law on bankruptcy has been in force.

\footnotetext{
${ }^{186}$ See, e.g., Fomin S. Federal'naiia sluzhba Rossii po finansivomy ozdorovleniiu i bankrotstvu - na segodniashnii den' edinstvennyi gosudarstvennyi organ, kotoryi v sostoiianii ispolnit' funktsii upolnomochennogo organa dlia osushchestvleniia gosudarstvennoi politiki po realizatsii prav gosudarstva kak kreditors (The Federal Service for Financial Rehabilitation and Bankruptcy of Russia today is the only federal agency capable of performing the functions of an empowered body for implementing state policy aimed at realizing the rights of the State as a creditor). - Antikrizisnoe upravleniie, 2003, No 3-4; also see Samodurov V. Vlast' ne proshchaiet dolgi (The authority does not forgive debts). An interview with the Director of the FSFRB of Russia Trefilova T. I. - Muzhskaia rabota, 2003, No. 4; On-line conference with Trefilova T., by the "Garant" company, 20 May 2003.
} 
Experts' evaluations of innovations in the bankruptcy law

\begin{tabular}{lll}
\hline \multicolumn{1}{c}{ Innovation } & \multicolumn{1}{c}{ Advantage } & \multicolumn{1}{c}{ Limitation } \\
\hline $\begin{array}{l}\text { Initiation of bankruptcy } \\
\text { is made more difficult }\end{array}$ & $\begin{array}{l}\text { Applying bankruptcy proce- } \\
\text { dures as means of taking } \\
\text { control over enterprises has } \\
\text { become more difficult }\end{array}$ & $\begin{array}{l}\text { Rights of honest creditors are } \\
\text { restricted, liquidation of ineffi- } \\
\text { cient enterprises becomes } \\
\text { more difficult }\end{array}$ \\
$\begin{array}{l}\text { Procedure of financial } \\
\text { rehabilitation is intro- } \\
\text { duced }\end{array}$ & $\begin{array}{l}\text { More opportunities for re- } \\
\text { storing debtor's solvency }\end{array}$ & $\begin{array}{l}\text { Opportunities are created for } \\
\text { dragging-out } \\
\text { cases }\end{array}$ \\
$\begin{array}{l}\text { Candidates for bank- } \\
\text { ruptcy commissioners } \\
\text { are nominated by SRO }\end{array}$ & $\begin{array}{l}\text { Bankruptcy commissioners } \\
\text { havecome less dependent }\end{array}$ & $\begin{array}{l}\text { Bankruptcy } \\
\text { becomes dependent on SRO }\end{array}$ \\
$\begin{array}{l}\text { Tougher requirements } \\
\text { to bankruptcy com- } \\
\text { missioners }\end{array}$ & $\begin{array}{l}\text { Professional level of bank- } \\
\text { ruptcy commissioners has } \\
\text { become higher }\end{array}$ & $\begin{array}{l}\text { Circle of potential bankruptcy } \\
\text { commissioners is unjustifiably } \\
\text { narrow }\end{array}$ \\
$\begin{array}{l}\text { Insurance of respon- } \\
\text { sibility of bankruptcy } \\
\text { commissioner is en- } \\
\text { visaged }\end{array}$ & $\begin{array}{l}\text { Compensation for losses } \\
\text { caused by unlawful actions of } \\
\text { bankruptcy commissioners is } \\
\text { List of special debtor } \\
\text { categories is extended }\end{array}$ & $\begin{array}{l}\text { Bankruptcy } \\
\text { becomes dependent on party } \\
\text { that provided funds for paying } \\
\text { insurance premium }\end{array}$ \\
\hline
\end{tabular}

\section{Example One}

On December 2, 2002, after three months of supervision, the Arbitrage Court of Amur Oblast introduced external administration at the Open Joint-Stock Company (OJSC) "Dal'vostugol'". The enterprise's credit indebtedness was about 3 billion roubles, its main creditor being the State. The enterprise was in the sphere of interests of the company "Russkii ugol'" of the "MDM" Group, the latter having control over about $30 \%$ of its shares. A. Zinchenko (according to some information, a protŭgn̆of "Russkii ugol'") was appointed the external administrator of the OJSC "Dal'vostugol"".

During the next two months, the administrator developed an external administration plan which, according to the FSFRB's Director T. Trefilova, was contrary to the interests of the State and society and did not meet any of the requirements of the Law on bankruptcy. The main criti- 
cism concerning this plan was that it did not have as its goal the restoration of the enterprise's solvency as a whole, but instead envisaged, in fact, the beginning of its liquidation in the course of external administration, which, as stated by the FSFRB's Director, was contrary to the mission of external administration and impinged on the interests of the debtor and the creditors. The plan envisaged that the debtor's entire business be sold under a direct purchase/sale contract, without auctioning and attracting a large number of buyers. T. Trefilova estimated this approach as a wrong one, because the highest market price can be determined only as a result of open bidding with the greatest possible number of participants. In her opinion, the plan contained no economic substantiation for the conclusion as to the impossibility of achieving any positive results of the enterprise's activity without transferring the right of ownership to another party. Nevertheless, according to the FSFRB's Director, the balance-sheet receivables amounted to 1.4 billion roubles. And the first priority in the plan of external administration was to be given to measures aimed at their recovery, which, most probably, would have resulted in the repayment of the main bulk of the enterprise's debts.

T. Trefilova was also displeased by the fact that the plan did not guarantee full redemption of credit indebtedness, nor the execution in full of the enterprise's current liabilities.

On the whole, according to the FSFRB's Director, the plan prepared by $A$. Zinchenko was of a declarative character, was not substantiated by appropriate estimations, and, in fact, could not be implemented, being contrary to the law and the interests of the State and other shareholders and creditors.

Also, T. Trefilova noted that the FSFRB had demanded on three occasions that A. Zinchenko hold a creditors' meeting, with an amicable settlement on the agenda, and each time the latter refused, whereas in accordance with the law the administrator is obliged, having received such a demand, to call the meeting within two weeks.

However, despite the negative response on the part of the FSFRB's top officials, the external administration plan for the OJSC "Dal'vostugol'", prepared by A. Zinchenko, was approved by the creditors' meeting on January 28,2003 . In this connection, according to $\mathrm{T}$. Trefilova, who personally represented the state creditors at that meet- 
ing, a number of violations were committed in the course of the latter. In particular, the external administrator failed to place on the meeting's agenda the issue concerning an amicable settlement, which had been the FSFRB's initiative ${ }^{187}$.

\section{Example 2}

In 1998, the procedure of external administration was introduced at the Korshunovskii Mining-Processiing Combine (MPC) - one of the largest producers of iron ore, with about 5,000 employees, and a budget-forming enterprise for the city of Zheleznogorst-llimskii and Nizhneilimskii Raion of Irkutsk Oblast. According to some data, the main cause of the Korshunovskii MPC's bankruptcy were the arrears of payments accumulated by the exclusive consumer of its product - the West Siberian Metallurgical Combine, presently owned by "Evraz Holding".

In June 2000, the procedure of external administration at the Korshunovskii MPC was extended until 2008, against the suretyship of the Oblast and local administrations.

In April 2002, the West Siberian Metallurgical Combine almost entirely stopped its payments for the concentrate being supplied by the Korshunovskii MPC. The latter, having been forced to terminate its operations, in effect was faced by the prospect of bankruptcy proceedings. In this connection, "Evraz Holding", whose activity at the West Siberian Metallurgical Combine had become, in fact, the cause of the profound crisis being experienced by the Korshunovskii MPC, was named as the most likely buyer of the latter's property.

In November 2002, the situation in respect to the Korshunovskii MPC underwent a fundamental change: it signed an agreement on strategic cooperation with the Cheliabinsk Metallurgical Combine ("Mechel"). Within the framework of this agreement, the Korshunovskii MPC began to ship its product to the Cheliabinsk, Magnitogorsk and Orsk-Khalilovsk Metallurgical Combines. Soon the Korshunovskii MPC, together with "Mechel", put forth a proposal concerning an amicable settlement. This initiative was supported by the Legislative Assembly of Irkutsk Oblast, by the Administration of Nizhneilimsk Raion, by several federal departments, by the Trade Union of Mining and Metallurgical

${ }^{187}$ Based on reports of the "AK\&M" agency, RF FSFRB. 
Enterprises of Russia, as well as by the emlpoyees of the Korshunovskii MPC itself. Approximately at the same time the FSFRB conducted an on-site audit of the MPC, during which, according to observers' opinion, a number of serious errors and violations were committed. In particular, the value of the Korshunovskii MPC's net assets was underestimated by 100 million roubles. Besides, no due regard was given to the period of the MPC's fruitful cooperation with "Mechel". Anyway, the results of the audit did not reflect the fact that the enterprise's solvency had begun to be restored.

In 2003, the Korshunovskii MPC achieved a profitable level of operation. By the results of the first four months, the Combine's balancesheet profit amounted to about 10 million roubles. By the results of the first half-year of 2003, the Korshunovskii MPC's profit was already about 80 million roubles. The average wage at the enterprise rose by $20 \%$. "Mechel" made investments in the Korshunovskii MPC's basic production and simultaneously began to repay its current debts.

In mid-2003, the FSFRB demanded that the suretyship's issuers the Oblast and local administrations - repay in full the enterprise's debt that was subject to a moratorium, which had arisen before the imposition of external administration and amounted to more than 500 million roubles. About this time, the Korshunovskii MPC became part of the Steel Group "Mechel”, one of Russia's largest industrial holdings. The Steel Group purchased the Combine's controlling block of shares, as well as the main bulk of its debts from its creditors in bankruptcy. The other creditors received proposals concerning the sale of their debt notes. In particular, such a proposal was offered to the East Siberian Railroad (ESR), the Korshunovskii MPC's liabilities to it having amounted to 5 million roubles, or $0,25 \%$ of the total debts. However, the railroad refused to sell the debt, a few days later petitioning to the Oblast Arbitrage Court that the Korshunovskii MPC be deemed to be bankrupt, and the proceedings in bankruptcy be initiated in respect to it. This petition was supported by the Irkutsk Oblast Administration and the FSFRB.

On the eve of the court hearings, the Korshunovskii MPC, in accordance with the FSFRB demand, redeemed in full its debt on which a moratorium had been imposed. This fact was officially confirmed by the Raion Tax Inspectorate. Simultaneously, the debts due to the creditors 
in bankruptcy were repaid in full, except those to companies affiliated to the Steel Group "Mechel". The repayment of the debt to the budget made it possible for the MPC's creditors to hold a meeting and make a decision concerning an amicable settlement. However, before the moment of the hearings, the local tax authorities had received a letter from RF Deputy Minister for Taxes and Levies F. Sadygov, where it was stated that the money transferred by the Korshunovskii MPC for the redemption of the debt on which a moratorium had been imposed (about 500 million roubles) were to be registered as a repayment of current debts. This letter, in its essence, was contrary to the norms established by tax legislation, stating that the decisions as to the allocation of tax payments lay within the competence of none other but the debtor. On the basis of this letter, the FSFRB succeeded in making the arbitrage court recognize as null and void the decisions made by a previously held creditors' meeting, abolishing the decision concerning the amicable settlement and dismissing external administrator I. Pomelnikov, whose duties, on the FSFRB's initiative, were delegated to S. Rozhkov, who, according to some data, was the protŭğ of "Evraz Holding" and had been nominated by neither the Korshunovskii MPC's creditors' committee, nor by a creditors' meeting.

It is remarkable that after these decisions had been made by the arbitrage court, F. Sadygov sent another letter, which annulled the statements contained in the pervious one and recognized the redemption by the Korshunovskii MPC of its debt subject to a moratorium. The Combine promptly appealed against the court decisions, but the new administrator, S. Rozhkov, recalled the ensuing suits.

In July 2003, in accordance with the court's ruling, S. Rozhkov held a new creditors' meeting, which was considered to be unlawful by the lawyers of the Steel Group "Mechel". In their opinion, S. Rozhkov commited a number of gross violations of the law. In particular, he unwarrantedly altered the meeting's agenda, having suggested that the creditors choose a self-regulating organization and change the composition of the creditors' committee. Besides, despite the recognition, by the RF MTS, of the fact of the moratorium debt redemption by the Korshunovskii MPC, S. Rozhkov entered the FSFRB into the creditor's reg- 
ister. The new creditors' committee now included two representatives of the FSFRB and, importantly, a representative of "Evraz Holding"

\section{Example 3}

In June 2002, the Inter-Sectoral Commission for the Supervision of the Efficiency of the Management of State Property of Novosibirsk Oblast made the decision concerning the initiation of bankruptcy procedures in respect to the Federal State Unitary Enterprise (FSUE) "Kometa", which belonged to military industry and was in the jurisdiction of the Russian Ammunitions Agency. This decision and the actions of the Oblast Administration which followed resulted in a conflict between the Administration and the federal authorities.

As of 1 July 2002, the FSUE's credit indebtedness amounted to 118.5 million roubles. The commission estimated the situation faced by the FSUE "Kometa" as a crisis, and found it reasonable to impose arbitrage management. In their subsequent comments, representatives of the regional administration were justifying this decision by their desire to prevent the destruction of the enterprise's production capacity and "to attract efficient owners". In particular, as Chairman of the Administration's Committee for Industry, S. Bobrov, noted: "An investor would never come to a pre-bankrupt enterprise, which is, moreover, a stateowned one, because it would be a high financial risk. Within the framework of external administration the law allows that a business be created and sold - and in this case it would not be difficult to attract efficient investments".

However, the natural assumption -that one of the existing large financial-industrial groups (for example, those located in Moscow) would come forth as the investor - proved unrealistic. On the contrary, it soon became obvious that it was the Oblast Administration that had the intention to make use of the FSUE "Kometa"' operational potential, or, more exactly, to make it available to the Inter-Sectoral Foundation for Energy Conservation and Development of the Fuel and Power Complex of Novosibirsk Oblast, organized by the Oblast Administration back in 1995 for the purposes of developing energy conservation technologies and manufacturing plastic piping, heat meters, etc.

\footnotetext{
${ }^{188}$ Losev A. Kak zakhvatit' predpriiatiie (How to take over an enterprise). - Novaiia gazeta of 21 July 2003.
} 
The Department for Economic development and Industry of the Novosibirsk Oblast Administration submitted to the Inter-Regional Territorial Body (IRTB) of the FSFRB a petition that the financial status of the FSUE "Kometa" be reviewed and the issue be resolved "on site". For the post of bankruptcy commissioners, A. Kataev was recommended. However, the status of a federal state unitary enterprise required that the issue of its financial status be considered at the federal level - within the framework of the Interdepartmental Balance Commission at the FSFRB. The Commission's meeting took place in mid-2002; however, its conclusions and results were rather vague. And the Russian Ammunitions Agency's appeal to the FSFRB with arguments against the enterprise's bankruptcy was submitted too late.

As stated by Head of the IRTB of the FSFRB for Suberian Federal Okrug A. Kikin, "In Moscow, they agreed that bankruptcy was feasible, and gave us appropriate directions. We implemented all the measures necessary to initiate the procedure in accordance with the new Law "On insolvency (bankruptcy)". The FSUE "Kometa"'s director, Pavel Kantsler, was not persuasive in his arguments against bankruptcy, and therefore the next step was our petition to the court".

The plans of the IRTB of the FSFRB were suddenly disrupted by none other than P. Kantsler. In contradiction to his previously expressed wish that the FSUE "Kometa" was not to be deemed to be bankrupt, he himself filed a petition in bankruptcy. Also, according to some information, P. Kantsler coordinated his actions with the Oblast Administration. The director's petition, according to A. Kikin, was filed just several days ahead of a similar petition filed by the IRTB of the FSFRB. Thus, the latter found itself sidelined, as far as the issues pertaining to the FSUE "Kometa"'s situation were concerned, including the candidate for the post of anti-crisis administrator.

According to the representatives of the IRTB of the FSFRB, the initiation of bankruptcy procedures in respect to the FSUE "Kometa" was unlawful, because at that moment no due regard was given to the rights of its property's owner, the Russian Ammunition Agency. However, the IRTB's attempt to file an appeal with the arbitrage court to the effect that the enterprise's bankruptcy be recognized as unlawful had no success: the Arbitrage Court of Novosibirsk Oblast rejected the appeal. 
This example is remarkable in that the conflicting parties were not business structures but the federal and regional levels of authority. Also remarkable is that the FSFRB's territorial agency 's position was to oppose not the bankruptcy of a federal enterprise as such, but only the procedural actions of the Oblast Administration, as a result of which the said agency lost its leading role in the process of bankruptcy ${ }^{189}$.

\section{Example 4}

In February 2002, bankruptcy proceedings were started in respect to Nizhnii-Novgorod Chemical Combine "Korund" - Russia's largest producer of synthetic corundum and cyanides. The enterprise's total current and moratorium debts amounted to about 1.5 billion roubles, including the debts to "Nizhnovenergo" - in the amount of about 380 million roubles.

In mid-May of 2003, the Combine's receiver M. Gorchakov, without the creditors' consent, sold the shares of "Korund"'s three subsidiaries "Predpriiatie"Korund"", "Chernorechenskii" and "Chernorechenskii khimzavod "Korund"”, in whose fixed assets the main bulk of its liquid property was listed - to the Open Joint-Stock Company (OJSC) "Matis", which represented the interests of the "Energoprom" company (the UGMK's affiliated structure). Thereby the receiver undermined the auctioning of "Korund"'s property complex initiated by its largest creditor in bankruptcy - "Nizhnovenergo". Remarkably, the lowest price at the auction was to be 310 million roubles, whereas the receiver sold the shares of "Korund"'s key subsidiaries for only 51 million roubles, having explained this by the need to promptly redeem the arrears of wages, amounting exactly to about 50 million roubles. It should be noted that in early June of 2003 M. Gorchakov was dismissed from his post on a motion by the creditors' committee, which, however, made no difference as to the outcome of the case ${ }^{190}$.

In the context of discussing the current possibilities of applying the institution of bankruptcy for uncivilized property redistribution and for taking over the control over enterprises, it seems necessary to reflect

\footnotetext{
${ }^{189}$ Barsukova N. Padeniie "Komety": bez shuma ne oboshlos' (The fall of "Kometa": not without noise). - Kontinent Sibir', 14 February 2003.

190 Tselibeev S., M. Rozhkova. "Korund dostalsia "Energopromu ("Korund" was taken by "Energoprom"). - Vedomosti, 6 June 2003.
} 
the general standpoint of state officials in respect to this issue. Thus, according to Director of the FSFRB T. Trefilova, by mid-2003 the positive effect of the enactment of the new Law had already revealed itself in terms of property protection. ${ }^{191}$ As stated by First Deputy Director of the FSFRB N. Kotsuba, the new Law is an efficient obstacle in the way of applying "orchestrated" bankruptcies for the sake of hostile takeovers. The opinion of Chairman of the Moscow Committee for Insolvency N. Badaev, that the application of bankruptcy as one of the methods for a hostile takeover has been abolished almost entirely, largely due to the new Law on bankruptcy, is also noteworthy ${ }^{192}$.

Of course, the official status of these persons leaves room for doubts as to the sincerity of their words. Nevertheless, there can be no doubts in respect to the fact that after the enactment of the new Law on bankruptcy, the scandals and conflicts indicative of attempts to apply bankruptcy as a means of uncivilized property redistribution and seizure of the control over enterprises have become noticeably less common. This circumstance, in conjunction with the opinions of state officials cited above, has led to the conclusion that in the new Law the problem of "strange" bankruptcies has been resolved more effieicntly that in the previous one.

${ }^{191}$ On-line conference with T. Trefilova, by the "Garant" company, 20 May 2003.

${ }^{192}$ Based on the materials of the Bureau for Legal Information, (www.bpi.ru), 19.12.2002. 


\section{Chapter 6. The institution of bankruptcy commissioners in contemporary Russia}

\subsection{Main Principles}

A bankruptcy commissioner represents one of the key figures in the bankruptcy process. It is the bankruptcy commissioner's actions that largely influence the efficiency with which bankruptcy procedures are implemented and the necessary equilibrium of interests of different parties - the debtor, the debtor's founders, and the creditors - is maintained. Within the framework of this chapter, the main phases in the development of legal regulation of the activity of bankruptcy commissioners are being discussed, as well as the approaches to determining their juridical status, the practical functions of the institute of bankruptcy commissioners, and the possible impact on it produced by the new Law on bankruptcy.

Due to the tremendous importance of the role of bankruptcy commissioners in the process of bankruptcy, as assigned to them by current legislation, the issue concerning their legal status appears noteworthy. According to V. Borodin, the main purpose of involving a bankruptcy commissioner in the bankruptcy process is to limit, to a varying degree, the powers of the former management to run an organization that has become an insolvent debtor, as well as to have the bankruptcy commissioner implement a set of special measures. During the procedure of supervision, the activity of a temporary administrator appointed by an arbitrage court is aimed at safeguarding property and carrying out a comprehensive analysis of the debtor's estate. In this connection, a wide range of rights and duties is delegated to the temporary administrator, thus enabling him to efficiently enough achieve the abovementioned goals of this bankruptcy procedure. Especial attention is paid to the fact that the initiation of the supervision procedure cannot serve as the grounds for dismissing the director or other administrative bodies of the debtor. However, this procedure requires that they obtain, on a mandatory basis, the temporary administrator's consent for the effec- 
tuation of certain transactions. Besides, the debtor's administrative bodies are not allowed to make certain decisions on their own ${ }^{193}$.

One of the possible consequences of the observation procedure can be the imposition, by an arbitrage court, of the procedure of external administration, which results in a radical change in the procedure of administering the debtor. The debtor's director is dismissed, and the management of the debtor's affairs is delegated to the external administrator. In contrast to a temporary administrator, an external administrator enjoys a much wider range of powers in respect to the management of an insolvent debtor, being invested for the duration of the period of external administration, with almost all the powers of the director and all the other administrative bodies of the debtor. This, however, does not mean that no restrictions at all are imposed on the actions of an external administrator: the effectuation of major deals and transactions, with related parties involved, is possible only with a preliminary consent of the creditors' meeting or the creditors' committee. The law also envisages other restrictions to the external administrator's independent power to dispose of the debtor's property.

Thus, supervision and external administration are regarded as forms of restricting the dispositive legal capacity of a juridical person, and in this sense the legal status of bankruptcy commissioners (or, more exactly, temporary and external administrators) has much in common with that of trustees and guardians of a physical person, though, of course, the goals and objects of administration in bankruptcy and those of the institution of trusteeship and guardianship are fundamentally different.

Major differences exist between the legal status of temporary and external administrators and that of a receiver who participates in the effectuation of the final stage of the bankruptcy process, that is, bankruptcy proceeding. In this connection, bankruptcy proceeding as such may be represented as a system of measures being implemented under the supervision of an arbitrage court, whose goal is, firstly, to effectuate the debtor's liquidation (as a juridical person), and secondly,

\footnotetext{
${ }^{193}$ See Borodin V. Pravovaia priroda statusa arbitrazhnykh upravliaiushchikh v zakonodatel'stve o nesostoiatelnosti i ptoblema pravosub"iektnosti iuridicheskikh lits (The legal nature of the status of bankruptcy commissioners, as determined in legislation on insolvency, and the problem of the legal personality of juridical persons). - Posted at: www.lawfirm.ru.
} 
commensurate the satisfaction of the claims put forth by the debtor's creditors. When making the decision that a debtor be deemed to be bankrupt and bankruptcy proceeding be initiated, the arbitrage court appoints a receiver.

While discussing the legal meaning of the status of receivers, $\mathrm{V}$. Borodin agrees with the viewpoint of $\mathrm{G}$. Sheshenevich who regarded bankruptcy proceeding as a qualified execution proceeding. The legal nature of the status of receivers is based on the execution of the decision made by an arbitrage court that a debtor (juridical person) be deemed to be bankrupt. The activity of a receiver is formalized to a much higher degree than that of the other types of administrators and has a very concrete purpose - that of the fairest possible distribution of a debtor's property among its creditors. On the contrary, the legal status of temporary and external administrators is based on their relatively independent actions, which are to a much lesser degree are bound by decisions made by other agencies (including the arbitrage court).

A somewhat different viewpoint concerning the status of bankruptcy commissioners has been put forth by S. Rukhtin ${ }^{194}$. In the author's opinion, the emergence of the creditors' right to participate in the administration of the debtor's affairs during the process of bankruptcy, and in effect - to manage the debtor's property (reflected in the possibility to choose a bankruptcy commissioner, determine the type of bankruptcy procedure to be applied, perform the functions of supervision, etc.), is associated with a change in the debtor's legal status. Therefore, the consolidation to creditors of the right to participate in administering the debtor's property through influencing the bankruptcy commissioner's will is none other but the right to determine the status of a bankruptcy commissioner within the framework of concrete legal relations.

Resulting from the dismissal of the debtor's administrative bodies, the administrative powers are transferred to a bankruptcy commissioner, who, however, does not become an administrative body as such either by definition or by the content of his powers. A bankruptcy commissioner is an independent subject of law, i.e., has independent rights, interests and will, and therefore acts in legal relations of his own behalf.

\footnotetext{
${ }^{194}$ Rukhtin S. Pravosposobnost' nesostoiatel'nosti iuridicheskogo litsa. (Legal capacity of insolvency of a juruducal person). - Rossiiskaia iustitsiia, No. 7, 2001.
} 
It means that in the legal relation of bankruptcy the role of the debtor is, in fact, played not by a debtor but by another person - a bankruptcy commissioner.

Thus, the "disappearance" from the civil turnover of one person (the debtor) entails the appearance of another person (bankruptcy commissioners), into whose authority all the debtor's estate is transferred, with the exception of certain rights associated directly with the debtor's personality. However, the bankruptcy commissioner as such is not independent in respect to the administration of the debtor's property. His behavior is determined by both the norms stipulated in the law and by the decisions of creditors' meetings.

\subsection{Regulation of the activity of bankruptcy commissioners: phases of development}

The institution of bankruptcy commissioners is an important and indispensable part of the institution of insolvency, and therefore its development in this country has been inalienably related to the development of the procedures and instruments of bankruptcy.

As a precursor of the institution of bankruptcy commissioners in Russia, the special institutions of independent and administrative managers can be pointed out, introduced in respect to state-controlled enterprises by the RF President's Edict of 14 June 1992 No. 623 "On measures designed to support and rehabilitate insolvent state enterprises (bankrupts) and on applying to them special procedures". This document envisaged the transfer of an enterprise deemed to be bankrupt, in order to reorganize it on a competitive basis, into the independent administration and jurisdiction of entrepreneurs - juridical or physical persons (including foreign ones) for the period of 6 to 18 months. In the event the competition did not result in the determination of the winner, or if after the expiry of the established period the independent entrepreneur failed to achieve the necessary positive results of reorganization, it was envisaged that direct administration of the enterprise be introduced for a period of 3 to 12 months (for agricultural enterprises up to 18 months), with the appointment, on a contractual basis, of an administrative manager. In the event the enterprise had a sole owner (the State), the administrative manager was appointed by an appropri- 
ate body of state authority, in the event of several owners - by a board established by the enterprise's owners and creditors.

During the process of a bankrupt enterprise's administration, the following duties were imposed on the independent entrepreneur or the administrative manager:

- the preservation of no less than $70 \%$ of jobs;

- the guarantees of social protection to the enterprise's employees, including the rights and interests of the employees being dismissed during the reorganization;

- the repayment of the enterprise's debts;

- the enterprise's environmental safety during the reorganization and as a result thereof.

During the period of reorganization, the independent entrepreneur or the administrative manager acquired full rights to effectuate the enterprise's administration, including the rights to:

- change the structure of operations and the orientation of production;

- appoint and dismiss employees, including the enterprise's CEOs;

- dispose of the enterprise's property (except leasing it), including the sale or mortgage of its fixed assets (except buildings and facilities) or circulating assets. In this connection, no less than $80 \%$ of the proceeds from the sale of mortgage of fixed or circulating assets were to be used for the purposes of financial rehabilitation and repayment of the enterprise's debts;

- make decisions, in coordination with a committee for property management, and in the event of the existence of several owners of the enterprise - in coordination with the board of the owners' representatives, concerning the enterprise's division, as well as its reorganization into an open joint-stock company;

- directly manage the production process.

In the event when the reorganization resulted in eliminating the grounds for an enterprise's bankruptcy, the independent entrepreneur would become its owner. Then, his share in the enterprise's property was constituted by his funds invested in the enterprise during the reorganization, as well as the enterprise's profit, as of the moment of making the decision concerning the termination of the status of bankruptcy, less the existing debt liabilities of the enterprise. An administrative 
manager, having successfully effectuated an enterprise's reorganization, would receive a lumpsum remuneration from the enterprise's funds in the amount of 25 salaries envisaged in the contract, as well as would be appointed, with his consent, the enterprise's director.

Phase I.

The actual onset of the legal history of the institution of bankruptcy commissioners in this country should be considered to be the adoption of RF Law "On insolvency (bankruptcy) of enterprises" of 19.11.1992 No. 3929-1 (hereinafter - the $1^{\text {st }}$ Law on bankruptcy). This document specified two categories of commissioners - the bankruptcy commissioner proper, or a person appointed by the arbitrage court, to whom the function of external administration of a debtor's property is to be delegated, and the receiver - a person who effectuates bankruptcy proceeding.

The bankruptcy commissioner was to be appointed by the arbitrage court when the procedures of external administration of a debtor's property were initiated. The debtor and creditors were granted the right to nominate their candidates for the administrator's post. If there were several such candidates, the appointment of the bankruptcy commissioner was made on a competitive basis.

In respect to the candidacy for the bankruptcy commissioner, the following major requirements were established:

- the person should be a professional economist or lawyer, or have an experience of economic management;

- should be a no record of conviction;

- the person should submit a declaration of incomes and estate.

Besides, it was established that no representative of the debtor's or a creditor's administration could be appointed bankruptcy commissioner.

The amount of remuneration to the bankruptcy commissioner was determined by a creditors' meeting and was subject to the approval by the arbitrage court. The remuneration to the bankruptcy commissioner was paid from the debtor's estate ${ }^{195}$.

\footnotetext{
${ }^{195}$ In the event when the petition for introducing external administration was filed by a debtor enterprise's owner or by the creditors, and the arbitrage court thereafter made the decision concerning the termination of the external administration of the debtor's prop-
} 
The sphere of competence of the bankruptcy commissioner was to be as follows:

- the administration of the debtor enterprise;

- the dismissal, in the event of necessity, of its director from the execution of the responsibilities pertaining to the administration of the debtor enterprise, and hiring and dismissing its employees;

- the disposal of the debtor's property;

- the calling of creditors' meetings;

- the development of a plan for external administration of the debtor's property and the organization of its implementation.

The receiver was to be appointed by an arbitrage court in the event of a debtor being deemed bankrupt and of the initiation, in respect to the latter, of bankruptcy proceeding. The requirements to the candidacy for the receiver were exactly the same as those to the candidacy for the bankruptcy commissioner.

From the moment of bankruptcy proceeding being initiated, the rights and responsibilities of the debtor's director were to be transferred to the receiver, the former having been dismissed by the court from this post. The list of the receiver's main functions was as follows:

- the administration of the debtor enterprise;

- an analysis of the debtor's financial status, an investigation as to whether the creditors' claims are truly substantiated, with their recognition or rejection;

- the conduct of an inventory and evaluation of the debtor's property and liabilities with the help of outside experts;

- the formation of the mass of the debtor's estate, including the activity aimed at recovering receivables;

- the submitting to the arbitrage court and to creditors all the necessary information concerning the debtor's financial status and property as of the moment of the initiation of bankruptcy proceeding;

- the formation of a liquidation board and direction over its activity;

- the effectuation of the sale of the debtor's property;

erty, or concerning the appointment of a new bankruptcy commissioner due to the rejection, by the creditors' meeting, of the external administration plan, the remuneration in full or in part could be charged to the party which had filed the petition concerning external administration. 
- the preparation of a report on his activity and its submission to the arbitrage court.

The receiver is granted the right to contest at the arbitrage court the transactions concluded by the debtor during the six months preceding the initiation of bankruptcy proceedings, as well as the decisions of creditors' meetings which surpass a creditors' meeting's competence or limit the powers of the receiver.

The amount of remuneration to the receiver was to be determined by a creditors' meeting and was subject to the approval by the arbitrage court.

The person of a receiver emerged also within the framework of the procedure of a debtor's voluntary liquidation as determined by the $1^{\text {st }}$ Law on bankruptcy. In this case, the receiver was appointed by the debtor's owners on the recommendation by its director, while the creditors, in their turn, were granted the right to appoint a new receiver instead of that appointed by the owners.

From the moment of the appointment of the receiver, the debtor's property was transferred to his disposal, the director being dismissed from the execution of the debtor's administration. The receiver's functions in general coincided with the functions performed by a bankruptcy commissioner within the framework of bankruptcy proceeding.

Phase II.

The onset of a new phase in the development of the institution of bankruptcy commissioners in Russia was marked by the enactment of Federal Law "On insolvency (bankruptcy)" of 8.01.1998 No 6-FZ (hereinafter - the $2^{\text {nd }}$ Law on bankruptcy). First of all, it should be noted that this document considerably expanded the list of requirements to the candidacy for a bankruptcy commissioner, having established, in particular, the following criteria:

- a bankruptcy commissioner should be registered as an individual entrepreneur;

- a bankruptcy commissioner should have specialized qualification;

- a bankruptcy commissioner should hold a special license issued by am empowered state body. In this connection, the recalling of such a license in the period during which the bankruptcy commissioner 
was executing his duties served as the grounds for his dismissal, by the arbitrage court, from the execution of these duties;

- a bankruptcy commissioner had to be registered with the arbitrage court.

The following persons could not be appointed bankruptcy commissioners:

- $\quad$ persons having a relation to the debtor or the creditors;

- persons who had previously managed the debtor's affairs, excepting in the cases when no less than three years had passed from the moment of this person's dismissal from the management of the debtor's affairs;

- $\quad$ persons in respect to whom there were established restrictions as to the right to manage the affairs and property of other persons (disqualified persons);

- $\quad$ persons with record of conviction.

A bankruptcy commissioner enjoyed the following basic rights:

- to convene a creditors' meeting and the creditors' committee;

- to appeal to an arbitrage court in instances envisaged by the law;

- to be remunerated in the amount envisaged by the law in accordance with the procedure established thereby;

- to attract other persons, in order to provide for the execution of his duties, on a contractual basis, with the payment for their activity from the debtor's estate, if not otherwise established by the law or by an agreement with the creditors;

- to petition with the arbitrage court concerning a pre-term termination of his duties.

The main duties of a bankruptcy commissioner included:

- to implement measures designed to protect the debtor's property;

- to analyze the debtor's financial status, financial, economic and investment activities, as well as the debtor's position on commodities markets;

- to consider the declared claims of the creditors.

Non-execution or undue execution, by a bankruptcy commissioner, of his duties could serve as the grounds for his dismissal by the arbitrage court, and in the event of incurring losses to the debtor or creditors - for recalling his license. In this connection, the debtor and creditors were granted the right to demand that the bankruptcy commis- 
sioner make compensation for the losses incurred as a result of his actions, which had been a violation of the law.

The remuneration to a bankruptcy commissioner was to be determined by a creditor's meeting and (or) the arbitrage court, if not otherwise established by the law.

Among the fundamental innovations introduced by the $2^{\text {nd }}$ Law on bankruptcy, a new bankruptcy procedure - that of observation - should be mentioned, and, consequently, the introduction of a new figure participating in bankruptcy - that of a temporary administrator. The temporary administrator was to be appointed by an arbitrage court from among the candidates nominated by the creditors, and in absence of such candidates - from among the bankruptcy commissioners registered with the arbitrage court, and in absence of the latter - from among the persons suggested by an empowered state body.

A temporary administrator was granted the following basic rights:

- to submit to the arbitrage court, in his own name, the demands that certain transactions be deemed null and void, as well as concerning the application of the consequences of the recognition as null and void of transactions concluded or implemented by the debtor with a violation of the requirements established by the law;

- to petition with the arbitrage court that additional measures be implemented in order to secure the safety of the debtor's property and that its director be dismissed from his post;

- to receive any information and documents concerning the debtor's operation. In this connection, the managerial bodies of the latter were obliged to grant such information to the temporary administrator.

A temporary administrator was entrusted with the following duties:

- to implement measures designed to secure the safety of the debtor's property;

- to analyze the debtor's financial status;

- to determine the presence of the indicia of fictitious and premeditated bankruptcy;

- to determine the debtor's creditors and the amounts of their claims, to notify the creditors concerning the initiation of bankruptcy procedures;

- $\quad$ to convene the first creditors' meeting; 
- to submit to the arbitrage court, on the completion of the supervision period, a report on his activity, the information concerning the debtor's financial status and proposals concerning the possibility or impossibility to restore its solvency.

The bankruptcy commissioner involved in the procedure of external administration was named, in the $2^{\text {nd }}$ Law on bankruptcy, an external administrator. The external administrator was to be appointed by an arbitrage court simultaneously with the introduction of external administration, and in the event of lack of such a possibility - within one month's period from the moment of the initiation of external administration $^{196}$. The external administrator was to be appointed by the arbitrage court from among the candidates nominated by the creditors, and in absence of such candidates - from among the bankruptcy commissioners registered with the arbitrage court, and in absence of the latter - from among the persons suggested by an empowered state body. In this connection, the temporary administrator could be considered as a candidate for the post of external administrator.

From the moment of introducing external administration, the powers of an empowered director and the debtor's other administrative bodies were to be transferred to the temporary administrator, who was thus granted the following rights:

- to independently dispose of the debtor's property, with due regard to the limitations envisaged by the law;

- to conclude, on the debtor's behalf, an amicable settlement;

- to declare a refusal to execute the debtor's contracts.

The external administrator was invested with the following basic duties:

- to receive in his jurisdiction the debtor's property and to conduct its inventory;

- to open a special account for the execution of external administration and settlements with the creditors;

- to develop an external administration plan and submit it for the approval of a creditors' meeting;

- to carry out accounting and reporting, to keep financial and statistical records;

\footnotetext{
${ }^{196}$ In this event, prior to the moment of appointing an external administrator, a temporary administrator had executed his powers.
} 
- to declare, in the established procedure, objections concerning the creditor's claims to the debtor;

- to implement measures designed to recover debts to the debtor;

- to consider the creditor's claims, and to keep their register;

- to submit to a creditors' meeting a report concerning the results of implementing the external administration plan.

As for the receiver, the $2^{\text {nd }}$ Law on bankruptcy established in respect to his appointment the same procedure as for the external administrator's appointment, while no fundamental changes, as compared to the $1^{\text {st }}$ Law, were introduced by this document in regard to the legal regime regulating his activity.

One of the key innovations introduced by the $2^{\text {nd }}$ Law on bankruptcy was the requirement that a bankruptcy commissioner have a special license. In this connection, we should mention the Provision concerning the licensing of the activity of a physical person in the function of a bankruptcy commissioner adopted as a "sequence" to the $2^{\text {nd }}$ Law on bankruptcy (approved by Decree of the RF Government of 25.12.1998 No. 1544, hereinafter - the Provision on licensing). This document, in particular, established the following:

- the issuing of licenses for the activity of bankruptcy commissioners was to be effectuated by the Federal Bankruptcy Service (FBS);

- in instances envisages by the law, the FBS's officials were appointed bankruptcy commissioners;

- in order to obtain a license, an applicant had to pass an examination in accordance with an educational program established by the FBS.

The FBS issued three categories of licenses

- first-category license granted the right to act as a bankruptcy commissioner or a deputy bankruptcy commissioner when bankruptcy procedures were being initiated only in respect to absent debtors, citizens, individual entrepreneurs and small enterprises;

- second-category license granted the right to act as a bankruptcy commissioner or a deputy bankruptcy commissioner when bankruptcy procedures were being initiated in respect to citizens, individual entrepreneurs and organizations, except those who belonged to the category of large and economically relevant. In order to obtain such a license, an applicant had to provide documentation 
to prove a record of having been employed as a bankruptcy commissioner during no less than 6 months;

- third-category license granted the right to act as a bankruptcy commissioner or a deputy bankruptcy commissioner when bankruptcy procedures were being initiated in respect to citizens, individual entrepreneurs and organizations. In order to obtain such a license, the applicant had to provide documentation to prove that during the period of employment under a second-category license, no less than two procedures of external administration and (or) bankruptcy proceeding had been completed and received a positive opinion of an experts' board for administration in bankruptcy, as well as to pass an examination under a professional improvement program approved by the FBS;

- the period of operation for license of all categories was to be 3 years.

It should be noted that the norms contained in the Provision on licensing, establishing three categories of licenses and requiring that in order to obtain second- and third-category licenses an applicant was to have an experience of successful activity as a bankruptcy commissioner, and in the latter case - also to pass an additional examination, were recognized as unlawful and not applicable by Decision of the RF Supreme Court of 07.09.2001 No. GKPI 2001-778, 911. However, as early as on 23.11.2001, the operation of this Decision was suspended by the Deputy Chairman of the RF Supreme Court until the end of the supervision proceeding.

By way of conclusion, we should like to note that on 1.07 .2002 (i.e., still during the period of the $2^{\text {nd }}$ Law on bankruptcy being in force) the licensing of the activity of bankruptcy commissioners was terminated (Federal Law of 13.03.2002 No. 28-FZ), which entailed the abolition of the Provision on licensing (Decree of the RF Government of 23.12.2002 No. 918).

\section{Phase III.}

The current phase in the development of the institution of bankruptcy commissioners began with the coming into force of Federal Law "On insolvency (bankruptcy)" of 26.10.2002 No. 127-FZ (hereinafter the 3rd Law on bankruptcy, or the Law currently in force). Many of its 
provisions establishing the legal procedure for the functioning of the institution of bankruptcy commissioners are close in content to the corresponding norms established by the previous, $2^{\text {nd }}$, Law on bankruptcy, and so, for the sake of shortness, we are going to discuss here only its main innovations.

1. The Law currently in force has once again modified the requirements to a bankruptcy commissioner, stating that this function can be performed by a citizen of the Russian Federation who answers the following criteria:

- is registered as an individual entrepreneurs;

- has received higher education;

- has a CEO's record of no less than two years, in total. A CEO's record is recognized as that of a juridical person's director or deputy director, as well as of a bankruptcy commissioner executing the duties of a debtor's director, except in the event of bankruptcy procedures being implemented in respect to an absent debtor;

- has passed an examination in theory in accordance with the program for training bankruptcy commissioners;

- has had training for a period of no less than six months on the job of a bankruptcy commissioner's assistant;

- has no record of conviction for crimes in the sphere of the economy, as well as for crimes of medium gravity, grave and exceptionally grave crimes;

- is a member of one of the established self-regulating organizations (for details concerning such organizations, see below). In this connection, a bankruptcy commissioner has the right to be a member of only one self-regulating organization.

Besides, an arbitrage court cannot approve, as candidates for the post of a bankruptcy commissioner, the following persons:

- those who have a relation to the debtor or creditors;

- in respect to whom bankruptcy procedures have been initiated;

- those who have made no compensation for losses incurred by the debtor, creditors, or third parties during the previous execution by them of the duties of a bankruptcy commissioner;

- those who have been disqualified or deprived, in accordance with the established procedure, of the right to hold office as CEOs and (or) to engage in entrepreneurial activity in respect to the manage- 
ment of juridical persons, or to be members of boards of directors and (or) manage the affairs and (or) property of other persons;

- those who have not concluded, in accordance with the requirements of the Law currently in force, contracts for insuring the responsibility for the losses incurred by the persons participating in bankruptcy procedures.

Finally, a creditor in bankruptcy, an empowered state body or a creditors' meeting has the right to envisage additional requirements to the candidates for a bankruptcy commissioner:

- higher education in law, economics or in the specialty corresponding to the debtor's sphere of activity;

- a certain record of employment as an organization's director in a corresponding branch of the economy;

- $\quad$ an established number of bankruptcy procedures previously effectuated by a candidate to the post of a bankruptcy commissioner.

When putting forth these requirements, a creditor in bankruptcy, an empowered body or a creditors' meeting has the right to specify the amount of and the procedure for an additional remuneration to the bankruptcy commissioner.

2. As follows from the abovesaid, for a bankruptcy commissioner to be appointed, a special contract concerning the insurance of his responsibility should be concluded. This contract should be effective for a period of no less than one year, with its subsequent mandatory prolongation for the same period, the insured amount being no less that 3 million roubles per year.

Also, a bankruptcy commissioner, within ten days from the date of the approval of his appointment by an arbitrage court within the framework of a bankruptcy case, must additionally insure his responsibility in respect to the possibility of causing losses to persons participating in this bankruptcy case, in the following amounts:

- if the balance-sheet value of the debtors' assets amounts to between 100 and 300 million roubles - 3\% of the balance-sheet value of the assets in excess of 100 million roubles;

- if the balance-sheet value of the debtors' assets amounts to between 300 million roubles and 1 billion roubles -6 million roubles and $2 \%$ of the balance-sheet value of the assets in excess of 300 million roubles; 
- if the balance-sheet value of the debtors' assets is over 1 billion roubles -20 million roubles and $1 \%$ of the balance-sheet value of the assets in excess of 1 billion roubles.

3. In the 3rd Law on bankruptcy, the procedure for appointing a bankruptcy commissioner has been substantially modified. In particular, it has been established that an arbitrage court (when introducing an observation procedure), or a creditors' meeting (in all other cases) submits to a self-regulating organization an inquiry concerning the presentation of candidates for the post of a bankruptcy commissioner, with possible specification of the requirements to the candidate. After receiving the inquiry, the self-regulating organization makes a list consisting of three of its members who have expressed their consent to being appointed a bankruptcy commissioner, and when the inquiry contains certain requirements to the candidates - those who to the greatest degree satisfy the requirements. The candidates are entered in the list in the order of their diminishing compliance to the requirements, and in absence of such requirements - in the order of their diminishing professional quality.

Then, no later than five days after the receipt of the inquiry, the selfregulating organization submits to the arbitrage court, to the creditors' meeting or to the applicant (the creditor who has filed the petition in bankruptcy), as well to the debtor, a list of candidates for the post of a bankruptcy commissioner containing the information concerning their professional qualities, and when the inquiry contains certain requirements - a substantiated conclusion as to their compliance to these requirements. The debtor and the petitioner (or a representative of a creditors' meeting) each have the right to challenge one of the candidates presented, and the remaining candidate is then approved by the arbitrage court. In the event when the debtor and (or) the petitioner (or the representative of a creditors' meeting) have not used their right of challenge, the arbitrage court appoints the first candidate on the list presented by the self-regulating organization.

Finally, in the event when the self-regulating organization does not present the list of candidates during the established period, the arbitrage court must apply with a request to an empowered state body, which is obliged, within seven days from the date of the receipt of the 
request, to ensure that other self-regulating organizations present their lists of candidates.

It should be emphasized that the procedure described here is applied when bankruptcy commissioners of all the categories envisaged by the law (temporary administrators, administrative managers, external administrators and receivers) are appointed.

4. The 3rd Law on bankruptcy has, as compared to the $2^{\text {nd }}$ Law, introduced a new bankruptcy procedure - that of financial recovery, resulting from which the institution of bankruptcy commissioners is augmented by one more figure - that of an administrative manager.

The administrative manager is granted the following basic rights:

- to demand from the debtor's director information concerning its current operations;

- to participate in an inventory, in the event it is conducted by the debtor;

- to coordinate the debtor's transactions and decisions in instances established by the law, and to submit to the creditors information concerning such transactions and decisions;

- to petition with the arbitrage court that the debtor's director be dismissed in instances established by the law, as well as that additional measures be implemented in order to secure the safety of the debtor's property, or that such measures be repealed;

- to submit to the arbitrage court, on his own behalf, demands that transactions and decisions be deemed to be null and void, as well as concerning the application of the consequences of the recognition as null and void of transactions concluded or implemented by the debtor with a violation of the requirements established by the law.

The main duties of an administrative manager are as follows:

- to keep a register of the creditors' claims, excepting in the instances envisaged by the law;

- to convene creditors' meetings in instances established by the law;

- to effectuate control over the implementation of the financial recovery plan and the schedule of debt repayments, to consider reports submitted by the debtor, to submit to creditors' meetings information and opinions concerning the implementation of the said plan and schedule; 
- to ensure that the transfers of money to satisfy the creditors' claims (including current claims) be effected timely and in-full;

- in the event of the debtor's failure to execute the liabilities in accordance with the schedule of debt repayments, to demand that the persons who have issued a suretyship for the execution by the debtor of its liabilities, fulfill the obligations that follow from the suretyship.

5. It seems that the most substantial innovation in the 3rd Law on bankruptcy in respect to bankruptcy commissioner is the introduction of the institution of self-regulating organizations. In accordance with the norms established by this Law, such organizations are assigned a very important role in the bankruptcy process. It is suffice to mention that it is the self-regulating organizations (and not the creditors, as used to be established by the 2nd Law) that submit for the arbitrage court's approval the lists of candidates for the posts of bankruptcy commissioners.

In accordance with the Law currently in force, a self-regulating organization of bankruptcy commissioners is a non-commercial organization based on membership, founded by citizens of the Russian Federation, entered in the Single State Register of self-regulating organizations of bankruptcy commissioners, the purposes of whose activity are those of regulating and ensuring the function of bankruptcy commissioners.

The status of a self-regulating organization of bankruptcy commissioners is acquired by a non-commercial organization from the date of its entry in the Single State Register of self-regulating organizations. The basis for the organization's entry in the Register is its compliance with the following requirements:

- that no less than one hundred of its members meet the requirements established by the Law currently in force in respect to bankruptcy commissioners, excepting the requirements concerning mandatory membership in a self-regulating organization of bankruptcy commissioners;

- the participation of its members in no less than one hundred (in total) bankruptcy procedures, including on-going ones, excepting bankruptcy procedures in respect to absent debtors; 
- the existence of a compensation fund or property owned by a mutual insurance society, formed exclusively in the form of money from the members' contributions in the amount of no less than 50,000 roubles per member.

The compensation fund or the property owned by a mutual insurance society are formed for the purpose of providing financial security for the responsibility to compensate for losses inflicted by members of the self-regulating organization while executing the duties of a bankruptcy commissioner. The resources of compensation funds or the property owned by a mutual insurance society cannot be used for the execution of the liabilities of a self-regulating organization, or the liabilities of bankruptcy commissioners, if the emergence of such liabilities has not been associated with the execution of the functions envisaged by the Law currently in force.

A self-regulating organization of bankruptcy commissioners performs the following main functions:

- $\quad$ ensures that its members abide by legislation of the Russian Federation and the rules of professional activity of a bankruptcy commissioner;

- $\quad$ protects the rights and lawful interests of its members;

- ensures openness in respect to information concerning the activity of its members and bankruptcy procedures;

- $\quad$ promotes improvement of the level of professional qualification of its members.

Within a self-regulating organization of bankruptcy commissioners, beside an executive body, a standing collegial managerial body is formed, consisting of no less than seven persons. The competence of this body includes the approval of the rules of activity and business ethics of the self-regulating organization's members functioning as bankruptcy commissioners. State and municipal officials cannot be members in the administrative bodies of a self-regulating organization.

A self-regulating organization of bankruptcy commissioners enjoys the following basic rights:

- to represent the lawful interests of its members in their relations with bodies of state authority and local self-government; 
- to notify the arbitrage courts of the Russian Federation concerning the acquisition of the status of self-regulating organizations of bankruptcy commissioners;

- to appeal in the judicial procedure against those acts and actions of bodies of state authority and local self-government that violate the rights and lawful interests of any of its members or a group of members;

- to file suits for the protection of the rights and lawful interests of persons participating in bankruptcy cases;

- to apply to its members disciplinary measures envisaged by its constitutive documents or by other documents, including expulsion from the membership in the self-regulating organization;

- to petition to an arbitrage court that its members, whose actions (or lack of action) involved violations of bankruptcy legislation, be dismissed from the participation in bankruptcy proceedings.

A self-regulating organization of bankruptcy commissioners is obliged to:

- develop and establish rules of the professional activity of a bankruptcy commissioner, mandatory for all its members ;

- control the professional activity of its members in the part concerning the compliance with the requirements established by the Law currently in force and with the rules of the professional activity of a bankruptcy commissioner established by the self-regulating organization;

- consider the complaints against the actions of its member executing the duties of a bankruptcy commissioner in a bankruptcy case;

- develop and establish the requirements to be applied to citizens of the Russian Federation desiring to enter a self-regulating organization;

- to notify the arbitrage court which is considering the bankruptcy case concerning the expulsion of its member executing the duties of a bankruptcy commissioner in this bankruptcy case, no later than within three days from the date of this member's expulsion;

- to collect, process and store information concerning the activity of its members, which they disclose to the self-regulating organization in the form of reports; 
- to organize and perform the training of a citizen of the Russian Federation as a bankruptcy commissioner's assistant;

- to keep a register of the bankruptcy commissioners who are its members, and provide free access to the information entered in such a register for persons interested in obtaining such information;

- to ensure the formation of a compensation fund or a property owned by a mutual insurance society for the provision of financial security of the responsibility to compensate for losses caused by its members while executing the duties of a bankruptcy commissioner;

- to submit to a regulating body, for the purpose of subsequent publication, information on the changes made to the constitutive documents, rules and standards of the activity and professional ethics of bankruptcy commissioners, as well as other information, as established by the Law currently in force ;

- to submit, at the request of a regulating body, reports concerning the bankruptcy procedures effectuated by the bankruptcy commissioner, who are members of self-regulating organization. 


\section{Chapter 7. Canadian corporate bankruptcy: law and public policy ${ }^{197}$}

As in so many other areas of its national existence, Canada's bankruptcy law and practices stem from a joint Anglo-French heritage ${ }^{198}$. From the United Kingdom comes the backbone of a creditor-friendly bankruptcy law, so different from the relatively populist and debtorfriendly Bankruptcy Code of the United States ${ }^{199}$. It is leavened with a sprinkling of imports from the Napoleonic Code civile, still the source of commercial law in Quebec.

The intent of this paper, a contribution to studies by the Institute for the Economy in Transition of Moscow preparatory to further amendments to Russian corporate bankruptcy law, is to outline certain features of the operation of Canadian bankruptcy law, both in general and in light of specific problems facing Russian reformers. The paper opens with some observations on the characteristics of a good ("optimal" is too strong a word) bankruptcy system and moves on to a summary description of how the Canadian system works. This is followed by a brief section on how the system has changed in recent years and on the topics that will likely feature on an agenda for further reform in the new Parliament. A recent example, the insolvency of Air Canada, illustrates how the present system works in a highly complex case. The paper con-

\footnotetext{
${ }^{197}$ I thank the following individuals, who have variously contributed advice, documents, memories and warnings in the preparation of this report. From Aird \& Berlis, Lawrence J. Crozier and Stephanie Fraser; from Industry Canada, Marc Mayrand, the Superintendent of Bankruptcy, Jacques Hains, Gilles Gauthier, Jim Buchanan and Andrei Sulzenko; from Sussex Circle, Jim Mitchell; from the Council of Ontario Universities, lan Clark. The author remains solely responsible for errors and omissions.

198 "Parents unmarried and living abroad..." Earle Birney, "Canada: a case history," in F.R. Scott and A.J.M. Smith, The blasted pine, Toronto, Macmillan, 1957.

${ }^{199}$ The Americans spent more than a century, from 1793 to 1898 , trying to define a stable bankruptcy regime. The financial houses of the northeast wanted solid creditor protection, while the agrarian south, oriented toward states' rights, tended to be sympathetic to debtors, especially farmers, and wanted no federal law. Several laws were passed and then repealed during the course of the $19^{\text {th }}$ century. It was not until the reorganization of failing railroads became a matter of urgency in the aftermath of the Civil War that a stable regime was finally established under federal jurisdiction, and even then it took until 1898. D.A. Skeel, Jr., Debt's dominion: a history of bankruptcy law in America, Princeton University Press, 2001.
} 
cludes with a summary response to questions raised by Russian colleagues.

\subsection{Background: economics of bankruptcy}

Bankruptcy procedures are often stated as having the equitable administration of the remaining assets of a bankrupt person or corporation as their fundamental purpose. In the words of a leading Canadian authority ${ }^{200}$, "bankruptcy legislation is designed:

1. to distribute the proceeds of the bankrupt's assets equitably and in accordance with a scheme of distribution;

2. to punish fraudulent debtors where there are breaches of certain standards of conduct;

3. to reform debtors whereby individual bankrupts can relieve themselves from financial obligations and become rehabilitated;

4. to promote confidence in the credit system such that credit grantors can believe that the system operates fairly with a means of seeking redress for wrongdoing and treating all persons of a like class in the same manner."

Many of the commentators on bankruptcy tend to come from a legal background. It is thus unsurprising to see an emphasis on fair and equitable procedures and the punishment of wrongdoers in their writing. From the point of view of economic policy, however, there are really two classes of objective - equity and efficiency - with the latter, perhaps because of its analytic interest, usually taking precedence among economic commentators. The first three objectives above address equity, while the fourth deals squarely with one of the principal issues of economic efficiency. In reality, of course, all involve efficiency through the provision of a structure in which the consequences of financial failure can be administered in a manner more orderly and less wasteful of economic resources than, for example, self-help or debtor's prisons.

From the viewpoint of economic efficiency, two broad objectives should inform policy. One, as Bennett notes, is creating and maintaining faith on the part of creditors that they will be dealt with fairly and swiftly in the case of the ultimate test of the debtor. Only if there is a

\footnotetext{
${ }^{200}$ F. Bennett. Bennett on creditors' and debtors' rights and remedies, $4^{\text {th }}$ ed., Carswell, Toronto, 1994, 534.
} 
widespread belief, supported by everyday administrative experience in hundreds of cases, in the predictability, speed and certainty of bankruptcy procedures can both transaction costs and the costs of debt capital itself be minimized. Keeping such costs low is of the essence when it comes to investment and economic development. What happens in the desperate world of bankruptcy affects all companies by affecting the cost and availability of capital.

The second economic efficiency objective has to do with the bankrupt estate itself, and is especially relevant to the case of corporate bankruptcy. There is a social interest in transferring the assets of the failed owners and managers into new hands as swiftly as possible so as to forestall the economic losses attendant on prolonged inaction. A company in bankruptcy will find it difficult to obtain new orders, acquire supplies and credit, and attract and retain energetic, talented workers and managers. A business that is fundamentally sound - capable of profitably producing goods or services if unburdened of past errors - is itself an important piece of social capital. If its structure of customers, suppliers, employment and tax contribution is destroyed, it may well be that all its individual production resources will in time find other employment in the economy, but only after large transaction costs, including the loss of the value of the firm as a going concern. Externalities include such losses not provable as claims in bankruptcy as those suffered by suppliers and their workers, a lessening of investment by those firms, customer costs incurred in searching for new suppliers, and the contribution to local charities and community life offered by the lost firm. In Canada, any tax loss carry-forwards disappear on the dissolution of the firm, when its assets are sold off piecemeal, which is one reason that acquisition is a frequent means of ending financial distress. There is thus a broad interest in maintaining the entity, so long as its going-concern value exceeds its liquidation value. This usually means restructuring or reorganizing the business to deal with the consequences of past errors by management or owners.

In practice, this efficiency objective is best approached by putting energetic new owners and managers who have concrete ideas about how to rejuvenate the business in charge - swiftly, and at a price which assigns the consequences of past errors to those who made them. Those who get to "take a haircut," as the Street slang has it, include 
owners of common stock, owners of preferred stock, unsecured creditors, secured creditors, and the Crown, in that order. The new owners typically creditors who have exchanged their debt for equity - will appoint new directors, and the directors in turn can be expected to appraise with a cool eye the managers who brought the firm to its knees. Many will be replaced.

The fundamental operational question during a corporate bankruptcy therefore rests on a judgment about whether economic value is best preserved by keeping the business going, albeit with a price to be paid in terms of restructuring, or whether to break it up and let its individual assets dissipate, eventually finding new employment elsewhere in the economy. This judgment usually has to be made under stressful and hurried conditions, and is constrained by the equitable rights of the many parties to a bankruptcy. And the bigger the corporate failure, the more complex are the claims. One test of bankruptcy law is thus whether or not such judgments can be made and carried out coolly and objectively under conditions of great stress.

The way in which this crucial judgment is made depends on the mechanics of the judicial and administrative systems under which it takes place. Creditor-friendly regimes, like that of the UK or Canada before 1992, generally put the assets of the failing firm in the hands of a trustee who quickly liquidates them, possibly in a single sale, for the benefit of the creditors. Management, directors and shareholders bear an immediate price. In such regimes there is a tendency for bankruptcy filing to occur rather later than economically optimal, as an increasingly desperate management with nothing to lose hazards ever-larger bets with other peoples' money. At the other end of the spectrum, the US Chapter 11 procedure may be making it too simple for managements to use bankruptcy as an ordinary piece of business strategy. Delaney cites the cases of Manville, Continental Airlines and Texaco as examples ${ }^{201}$. Further, judges operating under the US Chapter 11 procedure may be insufficiently expert. Baird and Morrison argue ${ }^{202}$.

\footnotetext{
${ }^{201}$ K.J. Delaney. Strategic bankruptcy: how corporations and creditors use Chapter 11 to their advantage, Berkeley, University of California Press, 1998.

${ }^{202}$ D.R. Baird and E.R. Morison. "Bankruptcy decision making," J. Law, Econ. \& Org., 17:2 (2001): 366-7.
} 
Bankruptcy judges are imperfect substitutes for market actors. Market actors have their own money on the line and this makes them intensely interested in making good decisions. Moreover, there is a natural sorting mechanism, as only those market actors who make good decisions survive. There is no similar competitive process or sorting mechanism for bankruptcy judges. They are subject to reappointment only every 14 years and making the shutdown decision is a small part of their docket. Moreover, the people who make the reappointment decision (other federal judges) are not themselves well positioned to assess the bankruptcy judge's performance.

In addition, once the Chapter 11 case starts, the judge must stand at a distance. Section 341 of the [US] Bankruptcy Code forbids the bankruptcy judge from attending the meetings at which managers of the firm must turn over information to the creditors. Rules of judicial conduct limit the ability of the bankruptcy judge to gather information informally. She cannot even talk to any of the players outside the presence of the others, nor can she conduct her own investigations.

The comments in the first paragraph could apply equally to Canadian judges, most of whom (outside of Toronto) hear bankruptcy cases with no special expertise.

A key point is that making the delicate decision whether to reorganize or liquidate depends on the fullest disclosure of relevant information, as well as experience and sagacity. Systems which force the early production of a great deal of information to all parties will tend to have better outcomes, in the sense that bargaining strategies in those circumstances are more likely to drive toward solutions where all parties are better off than they would be in situations of strong information asymmetry $^{203}$.

Equity is the other great economic objective. Although its impulse is social, stemming from innate feelings about fairness and natural justice, especially for parties less able to protect themselves through access to information or through good contracts, it too has a relation to economic efficiency. Only if claimants are dealt with fairly and reasonably swiftly can the risks and costs of extending credit be minimized. Prof. Davis, in a thoughtful but unpublished paper prepared for Industry

${ }^{203}$ K.E. Spier, "Settlement with multiple plaintiffs: the role of insolvency," J. Law, Econ. \& Org., 18:2(2002): 295. 
Canada as part of its preparation for the next round of legislative amendments, notes that there are a number of possible definitions of both equity and efficiency, but that in practice they are mutually supportive ${ }^{204}$.

Davis goes on to note that an optimal bankruptcy system must take account of the size and industrial structure of the economy to which it applies. A country dominated by small enterprises in large places whose individual disappearance will cause few external costs may be best served by a swift, rules-based system, whereas a country with a relative handful of large enterprises in small towns may need the flexibility to tailor solutions to specific cases. Canada has both, which leads Davis to suggest that the co-existence of a rules-based system together with one based on more general standards may suit its requirements better than the uniform Bankruptcy Code of the United States ${ }^{205}$. In addition, there is ambiguity about whether a specialized bankruptcy court is better than having such cases heard by judges having broad responsibilities ${ }^{206}$.

\subsection{The Canadian system}

Canada is a confederation of the British North American colonies left over after the revolutionary departure of the United States. Most were "colonies by settlement," meaning that, in general, all English law then in force and applicable to the circumstances of the particular colony were continued in colonial practice. Newfoundland, despite subsequent transfers between English and French sovereignty, was in 1583 the original British colony by settlement. One colony, Quebec, became English by conquest in 1759. In such cases the imposition of English law over the pre-existing regime, while still generally favoured, was strongly affected by the nature of the new territory. In the case of Quebec, with its French law and language and its strongly Catholic religious base, caution and magnanimity both led to the Quebec Act of 1774 in which

\footnotetext{
${ }^{204} \mathrm{~K}$. Davis, "An economic analysis of the differences between Canadian and American commercial insolvency laws," Industry Canada, March 2002, 66 p.

${ }^{205}$ Cf. L. Kaplow, "Rules versus standards: an economic analysis," Duke Law J., 42(1992): 557; P. Povel, "Optimal 'soft' or 'tough' bankruptcy procedures," J. Law, Econ, \& Org. 15:3(1999): 659-684.

${ }^{206}$ Davis, op. cit., pp. 21-26.
} 
many of the legal traditions of the French regime were continued. This English statute is now part of the constitution of Canada.

Four colonies (Upper and Lower Canada, corresponding to Ontario and Quebec today, plus New Brunswick and Nova Scotia) were united as Canada by the British North America Act of 1867, an act now referred to as the Constitution Act, 1867. Rupert's Land, essentially the present Prairie provinces, the Arctic and the Hudson Bay lowlands, was included as the North West Territories in 1870, with the new province of Manitoba carved out. Prince Edward Island and British Columbia joined in 1871 , and the present map was completed with the admission of Newfoundland in 1949.

Early statutes dealt with debt, seizure, insolvency, and the relief of debtors in the several colonies before Confederation ${ }^{207}$. Typically based on English statutes going back to the Renaissance, they applied only to "traders" and required the surrender of a debtor's property to a courtappointed official ("curator"), who would distribute the bankrupt estate among the creditors. Many types of debt survived bankruptcy, however, and no provision was typically made for the bankruptcy of individuals farmers, for example - or types of firms other than traders. In many respects the inheritance from the Napoleonic Code civil was superior, especially in that it included detailed procedures for the administration of the bankrupt estate. Concepts from that legal tradition entered British and later Canadian law through the "monumental work of revision and codification" ${ }^{208}$ of Quebec law following 1857.

The first attempt at a post-Confederation statute was The Insolvent Act of 1875, which repealed the mass of pre-existing colonial laws and applied a uniform structure to all the provinces. Coverage was broadened somewhat from traders and trading partnerships, and voluntary assignments were dropped in favour of creditor-initiated processes when a debtor generally failed to meet his liabilities as they became due. "Creditors, however, had the alternative remedy of applying to the Court for a writ of attachment under which the property of the debtor

\footnotetext{
${ }^{207}$ L. Duncan and J.D. Honsberger, Bankruptcy in Canada, $3^{\text {rd }}$ ed., Canadian Legal Authors, Toronto, 1961, ch. 2, pp. 5-14.

${ }^{208}$ L. Duncan and J.D. Honsberger, Bankruptcy in Canada, $3^{\text {rd }}$ ed., Canadian Legal Authors, Toronto, 1961, ch. 2, p. 10.
} 
was seized"209. However, although it was amended in 1876 and 1877 , the Act was repealed in 1880 and for forty years there was no general bankruptcy law in force in Canada. "There was dissatisfaction with the method of administration [a strength of the Code civil], and the constant irritation caused by ill-considered legislative tinkering with so important a piece of legislation brought to a head the movement for the repeal of the Act" ${ }^{210}$.

Three statutes presently govern bankruptcy in Canada. All are federal statutes, since Section 91(21) of the Constitution Act, 1867 assigned the subject to the federal level of government ${ }^{211}$. The basic statute, used for both commercial and personal bankruptcies, is the Bankruptcy and Insolvency Act (BIA), first enacted in 1919 and amended in 1949, 1992 and $1997^{212}$. Based on the 1904 United Kingdom statute, the 1919 Bankruptcy Act focused (until the amendments of 1992) on

${ }^{209}$ L. Duncan and J.D. Honsberger, Bankruptcy in Canada, $3^{\text {rd }}$ ed., Canadian Legal Authors, Toronto, 1961, ch. 2, p. 16.

${ }^{210}$ L. Duncan and J.D. Honsberger, Bankruptcy in Canada, $3^{\text {rd }}$ ed., Canadian Legal Authors, Toronto, 1961, ch. 2, p. 17.

${ }^{211}$ Section 92(13), however, assigns to the provinces the exclusive right to make laws in relation to "property and civil rights." As in other areas where this sometimes vague $19^{\text {th }}$ century statute of Westminster creates potential conflicts between the two levels of government, the courts resolve the conflicts by considering the "pith and substance" of the legislation. "If the primary object or pith and substance ... falls within one of the enumerated subjects of section 91 , it will be considered to be within the federal power notwithstanding that it may incidentally affect a subject matter which has been assigned to the provinces. Therefore, while the powers of the federal government in respect of bankruptcy and insolvency include the power to enact ancillary legislation to give effect to its legislation on bankruptcy and insolvency, these matters are limited to those matters which, in pith and substance, fall within the definition of bankruptcy and insolvency." Sean F. Dunphy, "Bankruptcy and insolvency, reorganization and winding-up," chapter 12 in M.E. Grottenthaler, ed., Doing business in Canada, Stikeman Elliott, Montreal, 1997. In addition, the BIA provides that the decisions of one provincial court are enforceable by any other, and all are required to act in aid of each other. In these ways, through the slow piling up of case law and through administrative cooperation, conflicts between the specific federal jurisdiction over bankruptcy and the much broader provincial responsibility for property and civil rights are managed with remarkably little friction.

${ }^{212}$ There had been Insolvency Acts in 1869 and 1875, but these were repealed in 1880 . The current (1997) Act is reproduced with substantial annotations in two well-known books: F. Bennett, Bennett on Bankruptcy, CCH, Toronto, $7^{\text {th }}$ ed., 2002, and L.W. Houlden and G.B. Morawetz, The 2003 annotated Bankruptcy and Insolvency Act, Carswell, Toronto, 2002 (annual). The bare text of the Act may be found (July 2003) at http://laws.justice.gc.ca/en/B-3/text.html. 
liquidation rather than reorganization. In 1992, Part III was broadened to expand the powers of debtor companies to effect proposals and supervised reorganizations.

A second statute, the Companies' Creditors Arrangement Act (CCAA), was enacted in 1933 in response to the grim economic conditions of the Depression ${ }^{213}$. A brief, reorganization-oriented statute, it gave judges latitude to make broad compromises, suiting outcomes to the peculiar circumstances of the time. It was not much used until the 1980s, when enterprising lawyers discovered it could be useful in the complex situation of large corporate bankruptcies. It was amended in 1997 to make it more consistent with the BIA.

The final statute in the trio, the Winding-up and Restructuring Act $(\mathrm{WUA})^{214}$, applies primarily to insolvent banks and insurance companies; unlike the other laws, which fall to the responsibility of the Minister of Industry, WUA is jointly administered by the Ministers of Finance and Industry. It is rarely used ${ }^{215}$. In addition it is possible conjointly to use the corporate organization statutes of either the federal (Canada Business Corporations Act, or CBCA) or provincial governments (such as the Ontario Business Corporations Act) to effect a restructuring of share capital where the company is insolvent ${ }^{216}$.

The Bankruptcy and Insolvency Act (BIA). The BIA is the basic statute. Its scheme is that, following an act of bankruptcy, the assets of an insolvent corporation are transferred to a trustee, who liquidates them for the benefit of the creditors. A company may be reorganized or sold as a going concern, with its basic contractual structure intact, or its assets may be sold in pieces. Creditors are paid according to a set order of priorities (Annex C).

Under the BIA a company can go bankrupt on its own motion, or its creditors may petition the court to have it declared bankrupt. In the first

\footnotetext{
${ }^{213}$ Both Bennett and Houlden \& Morawetz (note 11) include annotated texts of the CCAA. The bare text is available on http://laws.justice.gc.ca/en/C-36/text.html.

${ }^{214}$ Text available at http://laws.justice.gc.ca/en/W-11/text.html.

${ }^{215}$ But when it is, the cases tend to be spectacular, as in the case of the failure of Confederation Life in 1994: R. McQueen, Who killed Confederation Life? Toronto, McClelland \& Stewart, 1996.

${ }^{216}$ In addition, a Farm Debt Mediation Act of 1998 replaced the 1986 Farm Debt Review Act. Both are specialized versions of personal rather than corporate bankruptcy arrangements.
} 
case an insolvent debtor company may make an assignment of all its property to an Official Receiver or may make a proposal to its creditors for a restructuring of debt. Creditors also have the right to petition the Court for a receiving order which, assuming the debt involved exceeds $\$ 1,000$ and the debtor has committed one or more acts of bankruptcy, will normally be granted, putting the debtor company into bankruptcy. In either case the Official Receiver, who is an officer of the Court, chairs the first meeting of the creditors. In the case of a proposal, the debtor engages a trustee to perform the day-to-day administration of the bankrupt estate; in the case of an assignment, the creditors select the trustee. In the latter case, the trustee thereafter has complete control and administration of the assets, subject to oversight from the Court, the Superintendent, and the inspector(s) appointed by the creditors at their first meeting. The directors and the management of the insolvent firm have no discretion and may in fact be unemployed, although with the approval of the inspectors, some or all of the former managers may be retained to assist with the administration of the firm or other proceedings in bankruptcy.

In the case of a proposal, the debtor remains in control of its assets under the supervision of a trustee. Ultimately, the debtor must within six months obtain creditor and Court approval of its proposal.

Since the first step into bankruptcy entrains such serious consequences, it is not taken lightly; nor is it easy for a creditor to act on some technical breach to throw out management and seize the assets. The Court must be satisfied, on evidence and with the ability of the impugned debtor to contest the petition, that one or more of the ten acts of bankruptcy enumerated in section 42 of the BIA (see Annex A) have occurred within the six months preceding the filing of the petition. The judge, the Registrar of the Court, the Official Receiver and the Superintendent all remain seized of the issue until final disposition.

Trustees. The key player is the trustee. Private professionals licensed and regulated by the federal government through the Superintendent of Bankruptcy, trustees are usually chartered accountants; in any case they must pass rigourous examinations and keep up to date with changes in law and practice. They must avoid conflicts of interest 
and abide by ethical rules established by the Superintendent ${ }^{217}$. As the powers of the trustee (Annex B) are considerable and must usually be exercised under emergency conditions, high standards of training, experience, supervision and public reporting are important. The inspectors appointed by the creditors function as a special kind of board of directors and many of the actions of the trustee are subject to their approval. The Court remains available to resolve disputes.

The trustee is responsible for making a list of all creditors, taking control of the business and all its books and assets, deciding (with the approval of the inspectors) whether liquidation or sale as a going concern will yield best value, realizing that value, and paying the proceeds, less his fees, to the creditors according to the rights of precedence established in the Act. The procedures to be followed, right down to the forms to be used, are specified in considerable detail in the Act and elaborated in the Superintendent's Directives, which like regulations have the force of subordinate law. The trustee's multiple roles - administrator, creditors' agent, advisor and counselor to debtor - can cause conflict and must be managed scrupulously ${ }^{218}$.

The Superintendent of Bankruptcy. This official is a federal civil servant. A senior officer in the Industry department, he or she is subordinated to the Minister and Deputy Minister only in regard to resources and routine administrative matters and not in respect of the matters of his office. This arm's-length relation with the political system is shared with other officials of that Department who are named in statute, such as the Commissioner of Competition, the Commissioner of Patents, and the Director under the CBCA. The Superintendent's colleagues and superiors are not entitled to know information about bankrupts that is not part of the public record and a breach of that confidentiality would subject the Superintendent to disciplinary action up to and including dismissal. Only in cases where the Superintendent's actions are impugned

\footnotetext{
${ }^{217}$ Canada, Office of the Superintendent of Bankruptcy, "Code of ethics for trustees in bankruptcy," Ottawa, 2000; on website at http://osb-bsf.ic.gc.ca.

${ }^{218}$ I. Ramsay, "Market imperatives, professional discretion and the role of intermediaries in personal bankruptcy: a comparative study of the Canadian trustee in bankruptcy," Am. Bankr. Law J., 74:4(2000): 399-460. Ramsay's study focuses on personal bankruptcy, where arguably the possibility of conflict is more acute.
} 
does the Minister become involved, and then by convention only through a distinguished proxy ${ }^{219}$.

The Superintendent oversees the administration of all estates and matters to which the BIA applies. He does this by establishing standards for the licensing of trustees and by licensing them following examination, by requiring bonds from them as surety for the faithful fulfillment of their duties, by publishing Directives (including a code of ethical conduct) and information memoranda for the guidance of trustees, by intervening in Court on administrative matters on his own motion, and by keeping and publishing records. Matters of record include complaints against trustees, proposals, bankruptcies, licenses, and notices sent to receivers. Since 1992 he has had a limited mandate to keep records regarding reorganizations under CCAA, but this is a relatively undeveloped area. The costs of the Superintendent's office are partly recovered by a levy on trustees' distributions to creditors.

Receivers. In the Canadian law of secured transactions, the major remedy given to secured creditors is to provide that on default, a receiver may be appointed to immediately take possession of the collateral and either operate or liquidate the business for the benefit of the security holder. This technique is known in Canada as a "receivership". Such situations may be unrelated to bankruptcy, may precede it, or may become an incident in it. Receivers are private professionals hired by the creditor to realize on security. They are almost always but not necessarily qualified as trustees in bankruptcy.

The Companies' Creditors Arrangements Act. Unlike the BIA with its carefully choreographed, time-limited steps, CCAA is quite openended. Action under the CCAA commences with a Court application by the debtor company, and relief is in the discretion of the judge. Thereafter, control of the proceedings is entirely in the hands of the judge. The Act provides relatively little in terms of procedural guidance, with the result that judges have wide latitude to fashion procedures, actions and remedies that fit the case in hand. This flexibility is generally believed by

\footnotetext{
${ }^{219}$ In a 1993 case, for example, a trustee was found by the Superintendent to have falsified records and stolen money from a bankrupt's assets. The trustee was dismissed and his license to practice revoked. Following his suicide, the widow claimed compensation for lost income. In such cases the appeal lies directly with the minister, who invariably appoints, on advice, a senior administrative law judge, usually retired, to hear the appeal and make a decision on his behalf.
} 
the business community and its professional advisors to be useful, especially in the case of large and complex bankruptcies. Since 1997, access to procedures under the Act has been limited to insolvencies where the assets involved exceed $\$ 5$ million.

Canada does not have a specialized bankruptcy court, but it does have some judges who have become expert in these proceedings. In Ontario, under the leadership of Mr. Justice James Farley, a subset of provincial court judges known as the Commercial List have come to handle most CCAA cases ${ }^{220}$. There is a debate in the literature about how much a judge can be expected to know of the affairs of a given company in a complicated industry and whether a specialized court is a good thing or not ${ }^{221}$. Under the BIA the trustee is advised by a creditors' committee made up of creditors' representatives known as inspectors. The trustee may engage members of the former management for dayto-day administration, thus easing the expertise problem. Under CCAA, a wise judge makes the parties do most of the work while requiring the debtor through a court-appointed monitor to provide the court and all other parties with the voluminous information that alone can lead to wise choices. This aggressive involvement of the bench in requiring the production of information, even to the extent of intervening on its own behalf, is one striking difference from the US Chapter 11 process, where the judge must be at pains to keep a distance from the proceedings and the players and act only on the motion of one of the parties ${ }^{222}$.

Reorganization proposals. A company in or approaching insolvency may opt for reorganization rather than liquidation. It may proceed either under Part III of the BIA or, if liabilities exceed \$5 million, under CCAA. In

\footnotetext{
${ }^{220}$ Farley $\mathrm{J}$. is in charge of the current headline-making case of Air Canada. His style is to move rapidly, setting aggressive deadlines for parties to settle specific issues and report them to the court for approval. In this way the expert and involved parties hammer out the details, relieving the bench of all but procedural and final decision-making. Recently lawyers for contending groups of Air Canada pilots were startled to be ordered to complete their negotiation by midnight on a Saturday and report the results in court on Sunday morning.

${ }^{221}$ Davis, op. cit. 21. An interesting comparison of Canadian versus Chapter 11 procedures suggests that Canadian reorganizations are swifter, cheaper, and more likely to be consummated: T.C.G. Fisher and J. Martel, "Should we abolish Chapter 11? Evidence from Canada," J. Legal Stud, 28(1999): 233-257.

${ }^{222}$ D.G. Baird and E.R. Morrison, "Bankruptcy decision making," J. Law, Econ \& Org., 17:2(2001): 356-72; see also Davis, op. cit.
} 
either case, the distressed company makes a proposal to its creditors, who then decide whether or not to support it. A stay of proceedings by unsecured debtors normally follows while the restructuring takes place. At the end of the process it is expected that the company will continue under different ownership, and probably different management. The processes differ in detail, however.

BIA proposals. Under the BIA, reorganization starts with a filing in provincial court by an insolvent company of either a proposed compromise or rearrangement of creditors' claims, or, since fully fledged "prepackaged" proposals occur only in simple cases, a notice of intention to file such a proposal. The notice of intention includes the name of the trustee who has agreed to serve and the names of all creditors owed more than $\$ 250$ and the amounts owed. Copies of the filing must be delivered to all known creditors within 5 days, followed within 10 days of the original filing of a cash flow statement attested to by the trustee. There is an automatic stay of proceedings by all creditors including secured creditors for 30 days, although unsecured creditors can petition for abridgment on the grounds that no proposal could gain support.

The stay of legal proceedings is critical. Without it, uncoordinated "sauve qui peut" actions by creditors will consume all executive time, leaving no resources for managing the business or putting together a proposal or plan of arrangement. But such a large interference with the rights, obligations and expectations under normal contracts must be carefully hedged and time-constrained. Under the BIA a 30-day stay is automatic. Thereafter, if the Court is satisfied that the debtor is working in good faith toward a viable proposal that will not materially prejudice the rights of secured lenders, three further stays of 45 days each may be granted. As the BIA has no super-priority for debtor-in-possession financing, the debtor must finance operations from cash flow, from pledges of unsecured assets, or by using secured assets. Under the circumstances the Courts will interpret "material prejudice" to secured interests with a degree of liberality. However, "a secured creditor whose collateral is being consumed without being replaced will be wellpositioned to demand an end to the stay of proceedings" ${ }^{\prime 23}$.

Once a proposal is filed, the trustee calls a meeting of creditors within 21 days, during which the stay remains in place. Each class of

${ }^{223}$ Dunphy, op. cit, §12.04[3]. 
creditor votes separately, and it takes two-thirds in value and half in number of the creditors in a class for the proposal to bind that class. The Court is asked to approve the proposal but will refuse to do so if the terms are unreasonable, if the debtor has committed specific offences enumerated in Sections 198-200 of the Act (bankruptcy offences, failure to disclose the fact of being undischarged, failing to keep proper books of account), or if no super-priority has been provided for Crown claims, certain wage and landlord lease payments, and trustee fees. If the proposal is rejected by the creditors, or if there has been any fraud or default by the debtor, the proposal fails and the debtor is deemed to have made an assignment in bankruptcy. Liquidation follows.

A successful proposal must be fully performed. Once that happens, the trustee so certifies to the debtor and the Official Receiver and an application for discharge follows. Assuming good behaviour of the bankrupt during the period of the reorganization, the Court will grant discharge.

"A basic difference between a proposal under the BIA and a Chapter 11 reorganization under the US Bankruptcy Code is that in Canada, there must be a trustee who, as an officer of the Court, is responsible for administering the proposal. There is no provision under the BIA for a debtor in possession administering its own proposal as there is in the United States" 224 .

CCAA Plan of Arrangement. CCAA is more flexible. The grant, scope and timing of any stay are in the discretion of the judge, though case law is firming up. While the scope of the stay may be broader than under the BIA, the judge must be satisfied that the stay is in the best interests of both debtor and creditors. Under CCAA all classes of creditors must approve the plan of arrangement. Since 1997, the same two-thirds of value and half in number of creditors as in the BIA must approve. Since the greater the number of classes, the greater the probability of a refusal by one class, and since Canadian law does not include the US concept of "cram down" under Chapter 11, the definition of classes becomes a matter of some art. The definitions are proposed by the debtor, may be opposed by creditors, and must be approved by the judge.

${ }^{224}$ L.J. Crozier, personal communication. 
Under CCAA, the judge remains an active player throughout the entire proceeding. He is entitled to all information about the plan of arrangement and actions taken by any party under it. He must, under the statute, appoint a monitor (who may or not be the debtor's auditor) as an officer of the Court to oversee financial reporting and the debtor's actions generally. He may make such procedural or orders as he judges likely to lead to the attainment of the reorganization objective of the Act, and he may do so on his own account or on the motion of any of the parties.

"The CCAA has gained popularity as an instrument for the reorganization of insolvent debtors because it is a less technical and more flexible statute than the BIA. In addition, unlike the BIA, it has the advantage that the failure of a plan to obtain creditor approval does not result in automatic bankruptcy. However, as all proceedings under the CCAA are directed by the Court they are generally more costly than a reorganization under the BIA. Thus, the CCAA tends to be used only in very large retailing and manufacturing reorganizations. Most reorganizations in Canada occur under Part III of the BIA"225.

\subsection{Legislative reform of the Canadian Acts}

The BIA and CCAA are important pieces of marketplace framework legislation whose provisions affect thousands of companies directly and many more indirectly. They have important effects on the cost and availability of capital throughout the whole economy. Their provisions need periodic updating to take account of changing technology, commercial practices and social norms. It may be thought surprising, therefore, that the 1919 BIA has been amended only three times - twice in the last decade - and CCAA only once, and then largely as a consequence of the 1997 BIA amendments.

\section{Politics of reform}

In fact there are several reasons for these long delays. At heart is the problem that there is never much of a consensus among the various stakeholders about what amendments should be made. Creditors and debtors are competitive players in a less-than-zero-sum game and

${ }^{225}$ L.J. Crozier, personal communication. 
fiercely defend or seek to extend their existing priorities. Arguments are often polarized by references to heartless bankers throwing innocent people out of work through a too-zealous concern about the rights of secured creditors, or by the wrenching claims of unpaid wage-earners, trade creditors, widows and orphans, and even farmers and fishermen. Weak parties with inadequate information or contractual rights to protect their own interests are protected to a degree by statute - often, it may be claimed, at the price of near-fatal compromises of the commercial credit system. It does not help in these heated and political arguments that the external costs of bankruptcy, including higher interest costs generally, are borne by firms and individuals who may never otherwise contact the bankruptcy regime. Organized lobbies of interested parties may find it difficult to pass amendments to their liking, but they have less difficulty in blocking those favoured by others.

Under these circumstances there is little reward for politicians to risk their re-election on a subject where, it seems, any given proposal is opposed by three-quarters or more of the affected parties. Indeed, this was the legislative fate of comprehensive BIA amendment bills on several occasions between 1975 and 1984, following the TassŭReport of $1970^{226}$. Three events came together to allow the first amendments in 44 years to be passed in 1993. First, the US greatly modernized its procedures in its Bankruptcy Code of 1978. Here as in other areas the Canadian government realized that there is a market for good framework legislation, and that if Canada did not keep up with developments abroad it could become less attractive as a place for investment. Second, the professionals in the bankruptcy business - the lawyers, accountants and trustees - started through their professional organizations to put forward well-argued and expert views that were not especially tainted by pecuniary interest. The Insolvency Institute of Canada, the Canadian Insolvency Practitioners Association, and the Canadian Association of Insolvency and Restructuring Professionals in particular have all been helpful in keeping the matter in the public eye and in putting forward well-reasoned proposals ${ }^{227}$. Third, the Department (at first

\footnotetext{
${ }^{226}$ Canada, Department of Justice, Report of the study committee on bankruptcy and insolvency legislation (TassŭReport), Ottawa, 1970.

${ }^{227}$ Cf. A.F. Kent et al, "Report of the Joint Task Force on business insolvency law reform," Insolvency Institute of Canada and Canadian Association of Restructuring Professionals,
} 
Consumer and Corporate Affairs and, after 1993, Industry Canada) learned that excellent analysis and legislative drafting done in secret had a wonderfully unifying effect on all interested parties when the surprise result appeared for first reading in the House of Commons. Unfortunately it tended to unify all parties against the Government proposal.

A breakthrough came in 1986 when, on the basis of the Colter Report $^{228}$, the government undertook wide consultations with a view to finding compromise and consensus on as many terms as possible. This process, called by the officials who led it as "putting the inmates in charge of the asylum" 229 , produced a reasonable consensus on a number of issues but fell short of the stem-to-gudgeon rewrite that many had hoped for. This is inherent in policy processes based on compromise and consensus but has the advantages of avoiding egregious error and smoothing legislative passage.

The 1992 amendments were thus explicitly seen as the first phase of a modernization process that would extend over many years - in fact, indefinitely. Taking as example the Bank Act, which contains a clause requiring Parliamentary attention every ten years, officials inserted a reopener clause in the 1992 amendments, a clause that survived in 1997 and which will assure Parliamentary attention to the Act again in 2005.

For the 1997 amendment package - phase two - an external Bankruptcy and Insolvency Advisory Committee of more than 100 individuals representing about 50 organized interests was created under the chairmanship of the deputy minister. All interested parties - lenders, lawyers, trustees, consumers, students, labour unions, academics were invited to spend many hours of mostly voluntary time over a period of some two years to hammer out the specifics of amendments that could be recommended by all. Sub-committees did research and reached workable compromises in a large number of specialized areas. Since the field of possible amendments was wide there was opportunity for a particular interest group to yield something in one area for a com-

March 2002. Some would even argue that there may be too much professional influence on legal draftsmanship: B.G. Carruthers and T.C Halliday, "Professionals in systemic reform of bankruptcy laws: the 1978 U.S. Bankruptcy Code and the English Insolvency Act 1986," Am. Bankr. Law J. 74:1(2000): 35-75.

${ }^{228}$ Canada, Consumer and Corporate Affairs, Proposed Bankruptcy Act amendments, Report of the Advisory Committee on Bankruptcy and Insolvency, $2^{\text {nd }}$ ed., Ottawa, 1986.

${ }^{229}$ M.R. Daniels, personal communication. 
pensating gain in another. The deputy minister promised that he would recommend all points of consensus to the Cabinet, with the high probability that these would pass into legislation since, as by definition noncontroversial items, they would consume relatively little parliamentary resources. Conversely, there were likely to be a small number of vital topics on which no consensus was possible. In that case, the promise was that the department's preference (not necessarily the Committee's) would form the basis of recommendations, and the Committee members would not get a chance to wordsmith the language. This was a powerful spur to cooperation and expanded consensus and in the end greatly eased passage through the House and Senate.

\section{Amendments of 1992 and 1997}

The main focus of the 1992 amendments was to shift the emphasis from straightforward asset liquidation to reorganization. A new commercial reorganization scheme, Part III, was added to the BIA. Secondary amendments streamlined the administration of bankruptcy and gave some protection to unpaid suppliers. Within five years of passage, some 3,000 reorganizations involving 17,000 jobs were performed under the new legislation, and about half the reorganized firms were still active and independent ${ }^{230}$.

Many of the 1997 reforms focused on ways to give effect to changing social norms in personal bankruptcy. On the corporate side, there were a number of reforms ${ }^{231}$ :

- Landlords' claims arising out of disclaimed leases could be for actual damages or for an amount determined by a formula (100 percent of the rent due in the first year after disclaimer, plus 15 percent of rent due over the remaining term, to an overall maximum not exceeding three years' rent), at the choice of the debtor.

- A super-priority was established for the governmental costs of environmental clean-up. Provinces in particular had been concerned about "orphan sites."

\footnotetext{
${ }^{230}$ By contrast, under the US Chapter 11 procedure, the success rate is about 8 percent.

${ }^{231}$ Summarized from the Senate briefing book prepared for the use of departmental officials in 1996; thanks to Jim Buchanan and Jacques Hains for the use of this historical document.
} 
- Trustees, however, were no longer personally liable for environmental damage unless caused by their gross negligence or willful misconduct. If issued a remedial order the insolvency practitioner can comply, contest the order, seek a stay to assess the economic consequences of compliance, or abandon the affected property.

- Disincentives to directors were removed in order to encourage them to stay on and make decisions necessary to salvage the insolvent business. Claims against directors could be compromised as part of a reorganization proposal, directors were provided with a due diligence defence against having paid a dividend while the corporation was insolvent, and a stay of proceedings on recourse against directors during reorganization proceedings was introduced.

- Domestic rules were clarified so as to increase cooperation and coordination in international insolvencies: courts could recognize foreign representatives, and could make facilitating or coordinating orders, including stays in Canada. BIA rules continue to protect $\mathrm{Ca}$ nadian creditors and assets, however.

- $\quad$ CCAA was amended to import some BIA rules ${ }^{232}$ for consistency and predictability while maintaining the flexibility to handle complex reorganizations. A threshold of $\$ 5$ million in liabilities was introduced. Financial disclosure by the debtor was greatly improved. A new officer of the Court, a monitor (who might be the debtor's auditor) could be appointed to examine the debtor's affairs and file reports with the court. An initial stay of up to 30 days, without automatic extension, was introduced, but certain financial contracts, letters of credit and guarantees were exempted from the stay.

- New provisions were added regarding securities firms. Regulatory bodies can now initiate petitions, and a special new act of bankruptcy was introduced: a suspension for failure to meet capital adequacy standards. Trustees may deal with securities accounts with-

\footnotetext{
${ }^{232}$ For example, as in the BIA, creditors and suppliers are no longer obliged to extend further credit or supplies; with respect to Crown claims, stays, priorities and distribution rights were made to mirror the BIA; use of only one statute was made mandatory; voting in creditor classes was made consistent at half in number representing two-thirds of assets; various standard BIA forms were imported; and the CCAA provisions relating to international insolvencies, environmental liabilities, and directors' liabilities were made consistent with the BIA.
} 
out waiting for permission from an inspector. Street name securities were vested in the trustee, pooled, and allocated to customers in proportion to their net equity claims.

- In addition a variety of technical amendments were introduced to improve administration.

The agenda for further reform

The Industry Canada report. Parliament commenced its 2004 review of the BIA, CCAA and related Acts with hearings before a Senate committee. In preparation, Industry Canada commissioned and published considerable research that has been boiled down into a summary report $^{233}$. Really a briefing book, the report isolates issues that may be ripe for reform and discusses options for their resolution without giving particular recommendations. Issues are grouped, however, in terms of the expected degree of consensus or controversy they will arouse.

The most controversial issues are thought to be the following:

- Wage-earner protection: the degree to which wage and pension income is protected. No consensus: this is the nexus of the classic less-than-zero-sum game.

- Unpaid pension contributions: whether the existing protection for unpaid contributions and unfunded liabilities of pension plans is adequate. Same comment.

- Debtor-in-possession (DIP) financing. There is agreement that in Pareto-efficient cases where secured debt would not be materially compromised new debt should be allowed to take precedent over old. The BIA does not contemplate this while CCAA seems to allow judges to do anything at all that they find to be in their "inherent jurisdiction." There is some envy about the rules on debtor-inpossession financing in Chapter 11 of the US Bankruptcy Code.

- Unpaid suppliers: as it stands, only suppliers of goods, not services, are given limited protection. Repossessing a service once performed, or information once provided, is difficult to say the least.

\footnotetext{
${ }^{233}$ Canada, Industry Canada, Corporate and Insolvency Law Policy Directorate, Report on the operation and administration of the Bankruptcy and Insolvency Act and the Companies' Creditors Arrangement Act, Ottawa, September 2002; available July 2003 on http://strategis.ic.gc.ca/epic/internet/incilp-pdci.nsf/vwapj/3040-

Bankruptcies.pdf/\$FILE/3040-Bankruptcies.pdf.
} 
- UNCITRAL: should the model law on cross-border insolvencies of the UN Working Group on Insolvency Law replace Part III of the BIA? Reciprocity may be part of the answer.

The second group of issues is thought to be bridgeable by compromise and careful drafting and include the following:

- Survival of contracts: real property leases as well as software licenses pose some novel problems.

- Integration of the BIA and CCAA: This appears to be a matter of editorial neatness more than substance, as there is broad agreement that both the BIA and CCAA styles of reorganization ought to continue to exist - perhaps with better provision of information under the CCAA regime.

- Directors' liability: Is the balance between attracting capable directors (and retaining them when, in a crisis, they are most needed) and creating sufficient onus to focus their attention correct?

- Likewise, sanctions for director and officer conduct detrimental to creditors: are they optimal, given the same need for balance?

- Transfers at undervalue and unfair or fraudulent preferences: these provisions have not been updated since 1949.

Finally, there were a number of uncontroversial, largely technical items that will almost certainly be added to the eventual Bill:

- Securities firm bankruptcies: there needs to be a better definition of customer name securities to give certainty to Registered Retirement Savings (and Education) Plan holdings, and trustees should be allowed to sell securities and distribute proceeds in cash rather than as securities.

- WUA: There is consensus that the Winding-up Act should be used only in the insolvency of a financial institution.

- Should stays of legal proceedings during reorganization apply to provincial regulators such as securities commissions and stock exchanges? No.

- Trustee liability for successor employer obligations and pension claims: there is broad agreement that the moves to circumscribe trustee liabilities in 1992 and 1997 should cover these remaining open-ended liabilities.

- Supervision of reorganizations under the CCAA: It is likely that the Superintendent will be called on to supplement the work of the 
Court by keeping records in a national and public registry, require monitors to be qualified trustees, handle complaints, and intervene at Court when necessary. In this way the presently scattered and inconsistent public records of CCAA actions can be brought up to BIA standards, leading among other things to better possibilities for research and analysis.

- Funding and operations of the Office of the Superintendent of Bankruptcy: New money and permission to use new technology is needed.

These issues are discussed in the Industry Canada report cited above. Another matter which may arise concerns the rules for the calculation of contingent liabilities and the degree to which they are to be taken into account in determining solvency. It is sometimes possible for new public policy, legal decisions, or other 'accidents' to lead a firm's management to choose a strategic bankruptcy or other disruption of normal commercial proceedings. This has been a problem in the US in the case of product liability suits, where courts have awarded astonishingly large damages, and may be the reason why the Ontario government has been unable to privatize Ontario Power Generation. In this case, despite (or perhaps because of) new federal legislation, the environmental liabilities for nuclear waste management are not calculable.

The Senate committee report. The Senate Standing Committee on Banking, Trade and Commerce took all these matters under advisement and held extensive hearings, reporting in November $2003^{234}$. The Report will doubtless carry much weight when the new House of Commons is convened in the fall of 2004.

The Committee made a number of recommendations. The most important, including those likely to be of most interest to Russian reformers, were as follows:

- Debtor-in-possession financing, which has appeared in Canadian practice on an ad hoc basis in CCAA proceedings, should be recog-

\footnotetext{
${ }^{234}$ Canada, Standing Senate Committee on Banking, Trade and Commerce, Debtors and creditors sharing the burden: a review of the Bankruptcy and Insolvency Act and the Companies' Creditors Arrangement Act, Ottawa, November 2003. This thoughtful and wide-ranging report contains, i.a., a summary of the history of Canadian insolvency legislation at Appendix $B$ and a useful review of legislation in other English-speaking countries at Appendix D.
} 
nized under both statutes, subject to approval by the Court. The lien of the DIP lender would be able to rank ahead of any existing security interests that the Court may specify, after hearing evidence on seven considerations proposed by the Joint Task Force on Business Insolvency Law Reform ${ }^{235}$, namely:

- $\quad$ "what arrangements have been made for the governance of the debtor during the proceedings;

- whether management is trustworthy and competent, and has the confidence of significant creditors;

- $\quad$ how long it will take to determine whether there is a going concern solution, either through a reorganization or a sale, that creates more value than liquidation;

- $\quad$ whether the DIP Ioan will enhance the prospects for a going concern solution or rehabilitation;

- the nature and value of the assets of the debtor;

- whether any creditors will be materially prejudiced during that period as a result of the continued operations of the debtor; and

- $\quad$ whether the debtor has provided a detailed cash flow for at least the next 120 days."

- Noting that the provisions against fraudulent preferences and transfers at undervalue had not been updated since 1949 and were thus subject to a wide variety of provincial procedures under ordinary debtor-creditor law, the Committee called for both Acts to be amended to ensure consistent and simplified rules for challenging such transactions. The Committee did not, however, specify the content of a possible new code, a matter that will require some thought. Considerable work will be necessary before amendments in 2005 can be drafted to deal with the subject in a durable manner.

- On a related matter, the sale of substantial assets or even parts of the business during reorganization should be allowed, but only with the prior approval of the Court. The Court would take into consideration whether the sales process was fair, reasonable, and transparent to the creditors. No sales to directors, officers or shareholders of the debtor would be allowed other than in exceptional circumstances.

\footnotetext{
${ }^{235}$ This entity brought together the views of the three principal professional organizations in the field and is evidence of the growing importance of such organizations in law reform.
} 
- Under both Acts, the Committee recommended that the Court have discretion to replace some or all of the debtor's directors if their presence was impeding reorganization, and that the Court have the power to approve the equity structure of the debtor in a reorganization plan, with or without shareholder approval.

- The potential conflicts of interest in the roles played by monitors (especially) and trustees should be addressed and eliminated, and all insolvency practitioners should be governed by a possibly expanded ethics code.

The foregoing recommendations have the effect of strengthening the already robust provisions against predatory and fraudulent takeovers and asset stripping by requiring greater transparency and by putting substantial new powers of approval and even independent action in the hands of judges. Other important recommendations include:

- The UNCITRAL model code for international insolvencies should be adopted, possibly with a requirement for reciprocity, and in any case with the addition of a Canadian creditors' committee, all subject to the supervision of the Court.

- The treatment of qualifying debt as "distress preferred shares," a measure which provides lower cost restructuring since dividend income is treated more favourably than interest in Canadian tax law, would be made easier. Tax obligations from the period prior to the point of bankruptcy would also be treated as pre-filing claims, allowing the reorganized company a fresh start from a tax point of view. The Department of Finance will probably object on revenue grounds to this tilting of the rules of the game toward reorganization and away from liquidation.

- The plea that equity claims should mimic US practice was rejected on the reasonable grounds that investors knowingly took the risks of equity, including the risk that issuers lied or withheld material facts, when they made their decisions.

- Of this class of other important recommendations, the most significant have to do with the disclaimer or assignment of executory contracts. Executory contracts are those that impose a performance obligation that continues past the date of contract signing. The Senate Committee recommendation would move Canadian practice toward that of the US by allowing both the disclaimer of executory 
contracts in force at the time of filing, and the assignment of such contracts by those in charge of liquidation or reorganization. In the first case, contracts such as collective labour agreements may impede or even make impossible a restructuring. Labour unions argued strenuously that they always bend when the choices become stark - i.e., they always behave reasonably when faced with dismal alternatives - and should not be forced to accept unilateral abrogation of freely bargained contracts. Executory contracts involving intellectual property issues like software licenses and copyrights also raise a number of questions where current practice does not yet offer robust guidance, either with respect to disclaimer or assignment. These are controversial matters and will not pass into legislation without a fight in the House of Commons.

The Senate Committee also made a number of recommendations for minor changes, most of which will not be controversial. The more controversial are those at the top of the following list:

- Repeal the protection for unpaid suppliers (unless they be among those politically potent lobby groups, fishermen or farmers);

- Reinstate the priority for claims by provincial workmen's compensation boards that was removed in 1997;

- Extend the exemption from stays to most provincial regulators, including securities regulators, and quasi-judicial tribunals;

- Create a general due diligence defence against personal liability for company directors;

- Likewise make it clear that trustees are not "successor employers" by clarifying the distinction between the personal liability of an insolvency practitioner from that of the debtor's estate;

- Expand specialized judicial education;

- Update the tariff of fees that may be charged by insolvency practitioners;

- Add rules regarding the insolvency of business trusts: this is a relatively novel form of business organization in Canada under which the entity is not taxed but passes on its profits and losses directly to the unit holder;

- Refrain from consolidating the BIA and CCAA, but on the other hand ensure that CCAA takes on the scheme of priorities now in the BIA, 
and arrange for a five-year review not just of these two acts but also the Winding-Up Act and the Farm Debt Mediation Act;

- Clarify the BIA definition of "net equity" and the status of cash in the accounts of bankrupt brokerages; and

- Allow the Superintendent of Bankruptcy to use certain dormant fund balances for research and practitioner education.

As may be seen, there is an imperfect overlap between the list of issues and options by Industry Canada and the recommendations of the Senate Standing Committee. All these materials, and the updated briefs by concerned parties, will come before a committee of the House of Commons when it meets again in the fall of 2004. The prospect for the passage of controversial measures in a minority government is not great, however, and it is for question at this point whether Parliament will get around to further reform of the insolvency statutes before another election.

Two general points arise from this discussion of bankruptcy reform in Canada. One is the importance of the rise of a cadre of professionals judges, lawyers, trustees, receivers, monitors, and the institutions and firms that house them - in terms of both pushing for reforms and sidelining the special pleadings of interest groups. Skeel makes the point that the US did not develop stable law in the area until the rise of an "elite" bar during the period of railroad reorganization following the Civil $W^{2}{ }^{236}$. In both countries the rise of professions objectively mediating between creditors and debtors in insolvencies has made the laws, and the system of practice, much more serviceable and less subject to abuse.

The second point is that creating space for a balanced assessment of the merits of reorganization versus liquidation is a good thing. It leads to a higher success rate in reorganizations, and conversely to swifter liquidation where that is the preferred conclusion; in so doing it minimizes the negative externalities caused by bankruptcy. In Canada, as noted, about half of BIA restructurings are still in business as independent entities five years after emergence from the stay of proceedings. In the US the comparable figure may be as low as eight percent - prima facie evidence that Chapter 11, in its lenience toward debtors, may be

${ }^{236}$ Skeel, op. cit., 48-70. 
trying too hard to save the unsalvageable at too high a price to the economy at large.

\subsection{The example of Air Canada}

On April 1, 2003, Canada's national airline filed for creditor protection under CCAA while it restructured its finances. This prominent case illustrates how the Canadian bankruptcy system works under conditions of complexity, large scale, and high stress.

Factors leading to insolvency

Most of the world's best-known air carriers grew up in an era of protectionism that privileged the various national flag carriers. Like agriculture, air transport largely escaped the strong thrust toward international trade liberalization that has characterized most developed-country industries since World War II. Firms enjoyed strong elements of monopoly. Regulated control over entry to markets gave airlines substantial power to set prices, with the result that no strong drive toward internal efficiency was long manifest in most firms. The result was predictable: inefficient route systems and labour practices, high costs, and high prices.

In 1979, the US government broke the logjam. Deregulation of prices and market entry began on a large scale. The effects were remarkable. Storied names like Pan Am, Braniff and Eastern went bankrupt - sometimes, given the vagaries of the US Bankruptcy Code's Chapter 11, passed into law the previous year, several times. Dozens of new airlines sprang up, many only to fail after a few years. Between 1979 and 2001, 137 U.S. carriers filed for bankruptcy ${ }^{237}$. A few, notably Southwest Airlines, understood that a new model was needed for a new era of truly mass air travel.

The Southwest story is well known, but since its emulation in Canada is a large part of the Air Canada story, it is worth noting its salient features. Only one type of aircraft, the Boeing 737, is used, thus simplifying maintenance and training. Labour costs are kept low by avoiding unionization, by multi-tasking, by creating unbureaucratic authority struc-

\footnotetext{
${ }^{237}$ George F. Will, "Always a bumpy ride," The Washington Post, May 9, 2002, p. A31, quoted in McArthur (note 41).
} 
tures, and by making a share of compensation dependent on the results of the whole airline. There is great emphasis on employee enthusiasm. Luxuries like multi-class seating, fine meals and wines, and loyalty programs with their build-up of deferred obligations, are avoided. The result is a cost per seat-mile that is often on the order of half that of the old-line companies.

Air Canada was born as Trans-Canada Airlines in 1937, a Crown corporation organized by a legendary Canadian industry minister, C.D. Howe $^{238}$. For historically accidental reasons it was initially a subsidiary of the state-owned Canadian National Railway. Federal regulators guaranteed its financial stability by awarding it a monopoly on transcontinental and international routes, even though rivals from the private sector were emerging and wished to be allowed to compete.

What was tolerable in Depression and war, and even in the expansionary 1950s and 1960s, became less so as the economy matured in the period after the Canadian centennial in 1967. Deregulation began with the election of a Progressive Conservative government in 1984. In 1985 Air Canada was privatized. At that stage, Canada had two competing national airlines, Air Canada and Canadian Pacific Airlines (CP), a private company owned by the Canadian Pacific Railway conglomerate. CP's difficulties led to its purchase by an upstart western airline, Pacific Western, which also acquired the highly reputed charter operator Wardair. The new mainline competitor flew under the name of Canadian Airlines International Limited (CAIL), though its call letters were still the old CP. The rivalry between these two high-cost national flag carriers was intense and was exacerbated by the western regional roots of CAIL and the eastern hub (Toronto) and head office (Montreal) of Air Canada. Even after the privatization of Air Canada in 1985, Canadian was seen as the champion of free enterprise, while Air Canada carried the reputation of an arrogant, out-of-touch state-owned enterprise.

Twice, in 1992 and again in 2000, Air Canada tried to take over CAIL. Its misfortune was winning in 2000 . Both times its tactics and the politics of the day made it appear heavy-handed and arrogant. Throughout the 1990s, CAIL was failing faster than Air Canada. Both were premium-

\footnotetext{
${ }^{238}$ A comprehensive and readable account of Air Canada's history is provided by Keith McArthur in Air monopoly: how Robert Milton's Air Canada won - and lost - control of Canada's skies, McClelland \& Stewart, 2004.
} 
price airlines whose profitability depended strongly on business travelers willing to pay high fares for comfort and convenience. When that model was threatened in the recession of 1990-92, both airlines lost money but CAIL nearly failed. Only government intervention in the form of a $\$ 75$ million loan guarantee kept it flying. Business conditions improved during the rest of the 1990s, but discount airlines began taking market share or forcing the majors to lower fares to compete. The problem was that fares that made WestJet and other discounters profitable were ruinous to lines with the high costs of CAIL and Air Canada.

In 2000, following a complex multi-party game of bids, bluffs, threats and counter-threats involving the airlines, their alliance partners, equipment suppliers, financiers, competitors ${ }^{239}$, and governments, Air Canada took over CAIL as a going concern. In so doing it took on CAIL's enormous debts and a labour force that had been taught to hate its old competitors. In retrospect Air Canada probably wishes it had taken the bloody-minded course of letting CAIL go bankrupt, leaving it free to cherry-pick among the routes, workers and assets of a liquidated firm. The federal government, however, did not want to see thousands of unemployed CAIL employees and hundreds of trade creditors out in the cold on the eve of a federal election. While not wanting to appear to take sides in an ostensibly private sector war, the government faced serious embarrassment if liquidation were to be the result of its airline competition policy.

Air Canada's projections in 2000 were rosy. As a monopoly it would have considerable pricing power, and it would not have to schedule poor-yielding flights just to keep market share from its rival. Rationalization would offer large savings. So confident was Robert Milton, Air Canada's president, that he guaranteed all the unions concerned that there would be no layoffs before the spring of 2002 at least.

\footnotetext{
${ }^{239}$ The major competing bidder was AMR, the parent of American Airlines, an alliance partner of CAIL and the provider of its vital reservation and passenger management systems, which teamed with Toronto-based Onex Corporation, a major Canadian player in the market for corporate control and restructuring. Onex was headed by a principal financial contributor to the Prime Minister and his party. In the end, the Onex-AMR bid was quashed by the Court, which ruled that the statutory 25 percent limit on foreign ownership would be breached by its acceptance. The implicit reliance on a political fix failed spectacularly.
} 
No sooner had the deal been struck, however, than things began to go seriously wrong. The tech-sector bust of 2000-01 took large numbers of the highest-yielding business class passengers out of the skies altogether, or consigned them to economy. In September 2001 the use of airliners to attack New York and Washington caused an enormous crisis for all airlines: traffic volumes fell disastrously - much more rapidly than airlines could shed capacity - while costs for security and insurance leapt. For Air Canada, furious actions, including the breaking of promises to unions about layoffs, turned a 2001 loss into a small profit in 2002, but then the third blow fell. The United States went to war in Iraq in March 2003, which substantially lowered traffic on the critical North Atlantic routes. And at roughly the same time, Toronto, the hub of Air Canada's worldwide operations, became the major non-Asian locus for Severe Acute Respiratory Syndrome (SARS). Weakly recovering Asia-Pacific volumes plummeted. By this time Air Canada had used up all its sources of financial resilience. Supplier prices and employee's wages had been forced down, aircraft and their engines sold and leased back, lines of credit drawn tight. Even so, insolvency was inevitable. On April Fool's Day 2003 Air Canada petitioned for protection from its creditors pending reorganization under CCAA. Mr. Justice James L. Farley, a Commercial List judge of the Superior Court of Ontario, granted the protection and appointed Murray McDonald of Ernst \& Young as monitor.

\section{Hammering out a proposal}

Air Canada has now been moving toward a restructuring proposal for more than a year. A reorganized Air Canada, one that would have good prospects of permanence, would have to be profitable in the new world of changed consumer demand, public policy, and competition that was emerging in the new millennium. Overwhelmingly this meant substantial cost reductions in order to reclaim market share from the upstart discounters as well as the farther-off threat of international competition cabotage - in home markets. A lower-cost airline might then be able to command the financial strength to be able to withstand the inevitable ups and downs of demand in an industry in which capacity (cost) was largely fixed in the short run. The strategy that has emerged so far has the following main thrusts: 
- Lower labour costs by about $\$ 1.3$ billion a year. This is to be accomplished through lower wages, reduced pension risks and benefits, reduced levels of passenger service, greater automation, and the contracting out of certain jobs to low-wage, non-unionized suppliers.

- Lower supplier costs, notably through the renegotiation of leases for aircraft and engines and through lower prices for onboard food. While General Electric Capital Aviation Services (GECAS) was willing to make some accommodation on leases, essentially through lengthening the terms so as to lower short-term cash requirements, the latter meant, for example, that CARA, the long-time supplier of Air Canada's in-flight meals, would have to lower the wages it paid its employees from $\$ 22$ to $\$ 12$ an hour, or see the work go abroad. Commissions to travel agents would disappear entirely, and customers would be required either to wrestle with the opacities of the Internet themselves or pay agents to do it for them.

- Lower fares aggressively to compete with the discounters - on routes where they offered competition.

- $\quad$ Seek new equity to replace that which had vanished ${ }^{240}$.

The new corporate strategy is outlined in the plan of arrangement published on June $30^{241}$. Older aircraft with high operating costs are being retiured and replaced with more efficient and generally smaller aircraft, thus improving load factors while maintaining flight frequencies. Forty-eight old aircraft are leaving the fleet and being replaced by a larger number of Embraer and Bombardier planes worth some $\$ 2$ billion. Employee headcount will decline by 6,300 and related expenses by

\footnotetext{
${ }^{240}$ Under the Air Canada proposal, the present common stock would become worthless. Since the date of filing, however, they have generally traded in the range of $\$ 1.00$ to $\$ 1.50$, a point which may have implication for the theory of efficient markets.

${ }^{241}$ Air Canada, Notice of meeting and proxy statement pertaining to a consolidated plan of reorganization, compromise and arrangement under the Companies Creditors Arrangements Act (Canada), the Canadian Business Corporations Act, and the Business Corporations Act (Alberta) involving Air Canada and ACE Aviation Holdings Inc. and certain of their subsidiaries, and preliminary short form prospectus pertaining to a rights offering of ACE Aviation Holdings Inc., Montreal, 30 June 2004. A primary source of public information as complex CCAA negotiations proceed is the periodic reporting of the monitor to the Court. As circumstances warrant, but on average every two weeks in the Air Canada case a detailed report, including recommendations where appropriate, is filed with the Court. These and other documents are available at www.stikeman.com/ac.
} 
$\$ 1.1$ biullion annulally. Several business units are to be set up as quasiindependent limited partnerships, including a technical services unti, Aertoplan, a groundhandling unit, an Air Canada online unit, and Jazz. In each case, a new holding company, ACE Aviation Holdings Inc., will be the general partner and Air Canada, an ACE subsidiary, will be the initial limited partner. Financially, all of the old Air Canada equity will have vanished and more than $\$ 5$ billion of its debt will have been compromised, to be replaced by $\$ 850$ million of new ACE common shares, $\$ 250$ million of preferred shares, and $\$ 2.3$ billion in long-term debt and capital leases.

An early decision under the restructuring plan was setting the requirement for new equity at $\$ 1.1$ billion. The question for management and existing creditors was how much of the firm had to be given away to a strategic investor in order to raise about 60 percent of that amount. The smaller the proportion the higher the implicit valuation of the firm and the more equity would be available at a cut rate to creditors in trade for compromised debt. With this in mind, Air Canada and its financial advisors sought bids from qualified investors where, in essence, the winner would be the investor specifying the lowest percentage of equity it would require for its $\$ 650$ million.

Air Canada's management set the qualifications for equity bidders. In addition to the statutory nationality limitations, Air Canada's management sought a stable, long-term financial shareholder that would acquire effective control but confine its interventions to financial performance rather than operational matters. Several US "vulture" capital firms were interested, but management feared these as short-term investors who might strip assets, flip shares to other undesirable investors at the earliest opportunity, or impose difficult conditions on or even replace management. One of Air Canada's lawyers, Calin Rovinescu of the distinguished Montreal legal firm Stikeman Elliott, knew the Li family of Hong Kong, which already had substantial investments in Canadian oil and real estate. Both of Li Ka-Shing's sons had Canadian citizenship, meaning that a Li bid would not be contingent on changing Air Canada's governing legislation, which set a limit of 25 percent on foreign ownership. Rovinescu joined Air Canada as Robert Milton's second in command and chief restructuring officer. 
In the event, Victor Li's Trinity Time Investments Inc. became a bidder for the new Air Canada equity, offering $\$ 650$ million for 31 percent of the reorganized airline and leaving 56 percent available to the company's creditors, who would have to pay $\$ 450$ million in new cash. Deutsche Bank (DB) guaranteed to buy any of the 56 percent not taken up by the creditors, at a premium of 15 percent. Outside the deal structure itself, Victor Li offered Rovinescu and Milton "retention bonuses" of about $\$ 21$ million each.

There were other offers, in particular from Cerberus Capital Management LP, a US based vulture fund. Either offer would provide Air Canada with new cash equity of $\$ 1.1$ billion. On November 8 2003, Air Canada announced it had selected the Li bid.

Cerberus countered with a sweetened offer, but one that was outside the rules for the bidding process that Air Canada had previously imposed. Its key feature was significantly improved creditor recovery, as the only voters in this election were to be offered $\$ 850$ million of new shares, with Cerberus guaranteeing to buy any not subscribed for at a premium of 20 percent. In terms of the original auction criterion, Cerberus would be paying $\$ 650$ million for only 25 percent of the equity, though its guarantee meant that there was a possibility that the US firm would wind up owning more than the 25 percent the law allowed. The offer was also crafted to appeal to Air Canada's unions by proposing to pay down the unfunded liabilities in the pension plan more quickly. But Air Canada's top executives would not be offered immediate retention bonuses ${ }^{242}$. Financial market commentators estimated that the Cerberus offer would improve creditor recoveries by 9 to 16 percent. Air Canada restated its preference for Trinity Time on grounds of lower execution risk - no changes to the policy regarding foreign ownership would be required - thus setting the stage for a series of decisions by the court ${ }^{243}$. Judge Farley had approved the November 8 selection of Trinity Time but made allowances for "best and final" offers by both parties by a fixed deadline. An appeal by a creditor was dismissed, with the

\footnotetext{
${ }^{242}$ Keith McArthur, "Rival Air Canada bid sees more for creditors," Globe \& Mail, 25 Nov. 2003 , B1.

${ }^{243}$ Keith McArthur, "Air Canada seeks rapid approval," Globe \& Mail, 26 November 2003, B7.
} 
Court of Appeals strongly supporting the management of the case by Judge Farley.

Mr. Justice Farley also approved an anomalous side deal over the objections of a group of unsecured creditors. Air Canada either had to renew its lucrative code-sharing arrangement with Lufthansa, including guaranteeing priority repayment of $\$ 300$ million owed to Lufthansa, or face an immediate and complete cut-off of a crucial element in its longterm recovery plan. Despite the principle that creditors should be treated equally, Judge Farley approved the deal, remarking only that it "should not become an accepted practice" ${ }^{244}$.

On 22 December 2003, Air Canada's board once again chose the Trinity Time offer, in part because in the interim back-up arrangements had been struck not just with DB but also with GECAS, which improved creditor recovery by about 15 points $^{245}$. Dissident creditors tried to arrange a marriage of the best features of the Cerberus offer and the DBGECAS back-up arrangements, but failed. Both offers were highly complex, depending as they did on a variety of actions by other parties by specified times as well as on a number of assumptions about the future of the airline business in Canada, and were thus technically difficult to value precisely. In the end, it was the unwillingness of DB and GECAS an affiliate of GE Capital Corporation, whose GE Canada Finance Holding Co. was the provider of $\$ 954$ million in debtor-in-possession financing - to be separated from Trinity Time that left theirs the only bid standing. The Court's final approval, despite much creditor grumbling and legal manoeuvring, left it the sole choice available. With the support of the monitor behind the Trinity Time bid, creditor opposition subsided by mid-January $2004^{246}$. With the equity issue ostensibly settled, attention turned to labour issues.

The first to surface was the $\$ 1.4$ billion shortfall in the pension account. The unions and the federal pension regulator, the Office of the Superintendent of Financial Institutions (OSFI), both wanted the shortfall to be repaid within the regulatory maximum of 5 years. Air Canada

\footnotetext{
${ }^{244}$ Paul Waldie, "Air Canada, Lufthansa deal approved despite objections," Globe \& Mail, 18 December 2003, B20.

${ }^{245}$ Keith McArthur, "UCC fights Air Canada monitor," Globe \& Mail, 7 January 2004.

${ }^{246}$ Keith McArthur. "Air Canada creditors drop bid opposition," Globe \& Mail, 16 January 2004, B1.
} 
management needed the cash for investment. A compromise was reached on 10 years, but the compromise did not include OSFI.

During these negotiations, a rogue issue suddenly arose. Trinity Time said that as a condition of its investment it wanted the unions to switch from defined benefit to defined contribution pension plans ${ }^{247}$. The unions, which had in principle given up $\$ 1.1$ billion a year in employees' wages and benefits, balked. An arcane issue became a dealbreaker. After seven weeks of furious bargaining, supervised by the Court, Victor Li withdrew his bid. ${ }^{248}$ Four days later, Calin Rovinescu resigned.

In addition to this central blow to Air Canada's restructuring plans, other distractions arose. The federal Minister of Transport chose this moment to state publicly that the government would not bail out the company $^{249}$. Air Canada, alleging that a WestJet executive who had formerly worked for Air Canada had systematically stolen flight management and fare planning information from an Air Canada intranet, sued WestJet for damages ${ }^{250}$. And the Greater Toronto Airports Authority (GTAA), unveiling losses stemming from lower than expected passenger traffic (as well as its grandiose construction program) set the stage for much higher landing fees at Air Canada's hub airport ${ }^{251}$. The everhelpful GTAA also attempted to renege on an agreement about gate access.

\footnotetext{
${ }^{247}$ Under defined benefit plans, the company is ultimately responsible for ensuring that there are sufficient funds to pay specified nominal pension amounts. Employer and employee contributions may be varied to take account of changing economic conditions and the investment performance of the pension fund. The contingent liability to the company may be large, which means that the underlying assumptions and the eventual payouts tend to be conservative. A defined contribution plan takes in fixed contributions from employers and employees, with the amounts eventually paid to pensioners wholly dependent on the performance of the fund in the interim. It is quite improbable, but not impossible, for employees to wind up worse off in this case. But the idea that pensioners should take any risk, however small, no matter how large the potential reward, was simply unacceptable to the unions, who felt strongly that fund management risks should be borne by the employer - or guaranteed by the state.

${ }^{248}$ John Partridge, Paul Waldie, Andrew Willis and Simon Tuck, "Li walks from plan to rescue Air Canada," Globe \& Mail, 3 April 2004, A1; Janet McFarland, "Many good reasons the Li deal didn't fly," Globe \& Mail, 3 April 2004, A4.

${ }^{249}$ Murray Brewster, "Air Canada flying solo, Valeri says," Globe \& Mail, 13 April 2004.

${ }^{250}$ Paul Waldie, "WestJet banned from using information," Globe \& Mail, 16 April 2004.

${ }^{251}$ Richard Bloom, "GTAA's loss more than triples in 2003," Globe \& Mail, 16 April 2004.
} 
Despite these distractions, intense negotiations with Air Canada's remaining financiers followed. DB made the key move, continuing with its offer to take up $\$ 450$ million and extending this to a guarantee to purchase any of a further $\$ 400$ million not taken up by creditors (though at a reduced premium of 7.5 percent). A further $\$ 250$ million would be dealt with later. Other parties made accommodations to spread the risk. The government announced that it would allow a rise in foreign ownership to 49 percent and would contemplate limiting the rent increases demanded by unaccountable airport authorities. OSFI reluctantly agreed to the ten-year plan for making up the unfunded liabilities in the pension plan. GE Capital Corporation agreed to continue with its offer of $\$ 1.8$ billion to finance new aircraft once the airline emerged from creditor protection. But both GECAS and DB imposed a requirement for a $\$ 200$ million annual cut in labour costs on top of the $\$ 1.1$ billion reluctantly agreed but not fully implemented by the unions in 2003 , and set demanding time limits on the negotiations and subsequent steps ${ }^{252}$. With a positive recommendation from the monitor, the Court speedily approved the new plan $^{253}$. The stage was thus re-set for the final battle: the wresting of the remaining concessions from the unions.

Several weeks of intense and occasionally histrionic bargaining followed. Again, the Court declined to impose a settlement. At one point, Mr. Justice Winkler ordered the Air Canada president and the head of the most recalcitrant union to meet and negotiate personally, in meetings he would chair. The required $\$ 200$ million was apportioned to each of the seven unions involved and agreement finally reached on May 20, subject to ratification votes by members ${ }^{254}$. The management group, including chief executive Robert Milton, also took salary cuts. Although a number of other events had to take place according to a demanding

\footnotetext{
${ }^{252}$ Keith McArthur, John Partridge and Simon Tuck, "Deutsche Bank to share bailout risk," Globe \& Mail, 26 April 2004, B1; John Partridge and Keith McArthur, "GE Capital extends Air Canada loan deadline," Globe \& Mail, 30 April 2004.

${ }^{253}$ Canadian Press, "Air Canada's plan to find new investor gets thumbs up," Globe \& Mail, 1 May 2004.

${ }^{254}$ John Partridge and Paul Waldie, "Hargrove and Air Canada finally cut a deal," Globe \& Mail, 21 May 2004, A1. Details of the final apportionment are in John Partridge, "Air Canada faces new series of critical deadlines," Globe \& Mail, 22 May 2004, B5.
} 
schedule over the spring and summer ${ }^{255}$, these hard-fought labour negotiations broke the back of the restructuring. The end result was forecast to be a decline in labour costs from $\$ 3.1$ to $\$ 2.0$ billion, in aircraft leases by $\$ 100$ million from $\$ 1.1$ billion, in supplier costs from $\$ 3.1$ billion to less than $\$ 2.8$ billion, and with interest payments drastically reduced from the 2002 level of $\$ 290$ million $^{256}$.

On June 23, a deal with an affiliate of Cerberus Capital Management LP was announced regarding the final $\$ 250$ million of new equity ${ }^{257}$. Cerberus will get convertible preferred shares with a stock dividend of 5 percent, meaning that its initial 9.2 percent of the company's equity will grow to 12.3 percent in seven years, when Air Canada can require its conversion to common. Cerberus gets three seats on an 11-member board to Deutsche Bank's four.

These cuts will still leave the company with costs per seat-mile substantially above those of WestJet and other discount airlines ${ }^{258}$. It will take some time to see whether, in a period of strongly rising fuel prices and continued terrorist threats, all of the present players in the Canadian airline market will survive.

\section{Public policy issues}

There were a number of public policy issues external to the insolvency of Air Canada itself that affected the actions taken by the federal government and thus the calculus of each of the creditors and unions involved.

Ownership. Under the Air Canada Public Participation Act, R.S.C. 1985, the statute under which Air Canada was privatized, non-residents were not permitted to own more than 25 percent of the shares of the

\footnotetext{
${ }^{255}$ The main steps are: arranging for a final $\$ 250$ million equity tranche (June 23), drawing up a final plan of arrangement (June 30), union ratification votes (July 9), creditor approval (August 15), and emergence from protection under the CCAA (September 30).

${ }^{256}$ Keith McArthur, "Cuts take harsh toll on Air Canada employees," Globe \& Mail, 21 May 2004, B1.

${ }^{257}$ John Partridge, "Air Canada strikes funding deal with Cerberus: U.S. vulture fund to invest \$250-million," Globe \& Mail, 24 June 2004, B1.

${ }^{258}$ In the fourth quarter of 2003 , with the bulk of the labour cost savings but not the advantages of the reconfigured fleet factored in, Air Canada was reported to face cost per seatmile of 18 cents, against 10.4 cents for WestJet, its principal domestic discount rival. Derek DeCloet, "Air Canada creditors deserve shot in cockpit," Globe \& Mail, 28 April 2004.
} 
company. In terms of any potential future restructuring, this was the most onerous of the clauses that separated Air Canada from run-ofthe-mill companies. It was the rock on which the proposed OnexAmerican Airlines takeover of CAIL foundered, and it complicated the search for new equity investors during the period of reorganization under the CCAA. Other conditions included the obligation to continue to provide services in both of Canada's official languages, to maintain repair and overhaul bases in Winnipeg, Montreal and Toronto, and to maintain the head office of the corporation in Montreal.

Competition. Canada has a moderately robust competition policy, embodied in its Competition Act, R.S.C. 1985. Even in a regulated sector like air transport, successive governments have tried to engineer a healthy degree of competition as a means of ensuring efficient service. With privatization and deregulation, the Minister of Transport was constrained to rely even more heavily on competition to ensure a healthy marketplace. It was the Minister's unavailing desire to keep at least separate organizations and brands active in the market that prolonged the agonies of CAIL, and subsequently visited on Air Canada a debt load and fractious labour force that were material causes of its eventual insolvency. When Air Canada acted, especially in the difficult 1999-2001 period, in the way textbooks suggest monopolists would, it was the threat (and reality) of regulation under the Competition Act, as well as the threat of allowing cabotage, that acted to moderate the behaviour of the airline.

Airports. A large anti-competitive element in air transport is the system of terminals. The availability of gates and landing slots, as well as their cost, can have a material impact on the success or failure of an airline. In Canada, the main airports used to be owned by the federal government. By 1990, however, this model had become unsustainable. A federal government then running large deficits could not afford the large capital investments required by new terminals and runways and was unwilling to pass the costs directly to passengers. The terminals looked more like utilitarian warehouses than the architecturally imaginative transit and retail establishments that the public had come to prefer. So the federal government turned their management over to a new class of entity, airport authorities, which were responsible to local governments and to airport users. In most cases this worked reasonably well. Montreal, Vancouver, Ottawa and other cities built new 
well. Montreal, Vancouver, Ottawa and other cities built new facilities that combined ease of use with moderate prices. The Greater Toronto Airport Authority, however, hired a visionary American who embarked on a $\$ 4$ billion expansion - just as traffic started to slacken at the turn of the century. Air Canada's central hub went from being a low-cost center to one of the highest in the world in three years - at the very time when its own crisis was at its worst ${ }^{259}$.

Regionalism and the temptation of direct investment. The identification of Air Canada with eastern Canada and CAIL with the west had led the federal government, much against its will, to prop up CAIL with loan guarantees during its struggle in 1992. In 2003-04, with the prospect of the disappearance of a national, not just regional, champion, the temptation to re-nationalize Air Canada was a powerful one, especially as an election was foreseen for the spring of 2004. In the event, marketminded ministers won, but not without a struggle behind the closed doors of the Cabinet room. The greatest excursion from established policy turned out to be a relaxation of the 25 percent rule: the government let it be known that going as far as 49 percent would be acceptable. Had the government not been firm in its stance, the incentive for the company and its unions to fight to an agreement on wages and work rules would have been impaired, probably fatally.

Liquidation's externalities. Mention has been made of the externalities consequent on bankruptcy and liquidation. In this case, substantial costs would be borne well beyond the ambit of Air Canada's managers, employees, and creditors. Airport authorities would be left with large if temporary deficiencies in their cash flow, with consequent impairments in their credit ratings and possible calls on governments for bail-out finance. The governing federal party, facing an election too close to call, might have found the shock enough to change the result. Consumers would lose frequent-flyer points worth hundreds of millions of dollars. Firms in the supply chain would lose a substantial market, at least until the rise of new carriers to fill the void left by the vanished airline. By that token, of course, enormous business opportunities would have been created for WestJet, CanJet, Jetsgo and the remaining domestic discount airlines, and for foreign carriers with respect to the lucrative trans-oceanic routes.

${ }^{259}$ Eric Reguly, "Terminal turbulence," Globe \& Mail, 30 April 2004. 
Stock market regulation. Air Canada's stock continued to trade on the Toronto Stock Exchange after its CCAA filing, despite explicit warnings from management that it was worthless under any scenario. Why the stock exchange or its regulator, the Ontario Securities Commission, failed to suspend trading remains a mystery.

\section{Issues under CCAA proceedings}

The most fundamental issue in an insolvency is whether to liquidate the remaining assets and distribute them among the creditors, or whether to attempt a reorganization. From a public policy point of view, the answer turns on external factors that transcend the concerns of the debtor and creditors in the action. In this sense it is somewhat anomalous that the decision, at least in the case of CCAA and other debtorfriendly regimes, is taken primarily at the instigation of the debtor, who remains in charge of the enterprise. Creditors' powers are, in the main, those of restraining or moderating the actions of the insolvent. It is instructive to observe the ways in which the embattled management of Air Canada dealt with the issues and parties in their insolvency.

Power of management. Reorganization has a far greater chance of rewarding incumbent management ${ }^{200}$ than does liquidation. In the latter case, under the BIA or a Court-ordered process, a third party is charged with a process that leaves at best only shards of the original business still in existence under new ownership, with the rest of the assets and workforce idled. Certain of the failed managers may be retained in the short term by the trustee in order to assist in the process, but at the end of that period they usually become unemployed. Shareholders, who may include members of the failed management, typically receive nothing or only a token amount for their shares. Directors lose their emoluments and prestige, and their reputations and hence hopes of future appointments are often diminished. There is thus a powerful inducement to select a process that maintains the power of manage-

\footnotetext{
${ }^{260}$ In the Air Canada case, as noted, the president and his chief restructuring officer were promised bonuses worth about $\$ 21$ million apiece by one bidder if that particular bidder was selected to provide the necessary new equity and thereby gain control of the airline. This clearly had the appearance of a conflict of interest. It is not surprising that management and the board that supported them persisted in their advocacy of this bidder rather longer than an objective view would have required. Only the collapse of the Li bid kept this issue from assuming more prominence, or possibly attracting the notice of the Court.
} 
ment as long as possible. Overwhelmingly, managements and boards of directors prefer reorganizations. It is thus incumbent on the Courts to intervene to protect the external public interest.

It is no surprise that the perennially optimistic management of Air Canada chose the reorganization route, and therefore filed under the reorganization-oriented CCAA, with a parallel filing under the Bankruptcy Code in the US.

Timing. Management's first choice has to do with timing. A premature application to the courts may be refused, or may be expensively objected to by an aggrieved creditor. This is what happened in the subsequent case of Stelco, the Hamilton, Ontario steel producer, where the labour union refused to accept the calculations of Stelco management and caused the company to spend time and good will it did not have in proving the point. Leaving it too late, however, exposes the company to pre-emptive actions by creditors, such as the seizure of assets for unpaid debts or a petition under the BIA. It was the threat of seizure of aircraft by unpaid airport authorities that precipitated the bankruptcy and sale of Canada 3000 , one of the several discount start-ups of the 1990s.

In the case of Air Canada, cash available to pay short-term liabilities had been eroding all through the fall and winter of 2002-03, leading the company to sell assets and to negotiate with its labour unions for lower wages and more relaxed work rules. When matters were at their most parlous, SARS struck, and revenues (but not costs) nose-dived. Air Canada, having pursued all options in an increasingly public manner, made application to the court only in extremis, and probably not long before pre-emption by one creditor or another.

Choice of Court. Air Canada could have applied to the courts of several provinces, though the real choice lay between Ontario, home of its major hub, and Quebec, where its headquarters were. Ontario, however, had established a "commercial list" within its Superior Court of judges experienced in bankruptcy and insolvency as well as other business issues. It was to this court that Air Canada applied, where the judge assigned was the highly experienced Mr. Justice James L. Farley. An important element of Justice Farley's style is a refusal to let particular interests delay an overall solution and a determination to keep parties moving toward solutions. A frequent tactic is to require parties with 
opposing interests to negotiate a solution on an urgent basis, under threat of the Court imposing a solution that, almost by definition, will be less than optimal. Distinguished lawyers have often found their nights and weekends commandeered by a judge whose experience tells him that delay is the great enemy of all.

Air Canada would certainly have preferred to file under Chapter 11 in the US, as that statute allows as a fairly automatic provision the setting aside of labour contracts and the "cramming down" of provisions which may be deeply unpalatable to a few creditors in the hope of saving the whole enterprise. In certain international cases a company may have, effectively, some degree of choice regarding the legal regime that is used to regulate a matter. But in this case the locus of activity was so clearly Canadian that no choice was possible. A last-ditch attempt to persuade the federal government to amend CCAA so as to make the nullification of labour contracts a normal rather than judicially discretionary act was rejected, as was a request for a billion-dollar loan or loan guarantee.

Defining the creditor classes. Under a CCAA plan of arrangement, each creditor class must approve the proposal. At least half of the creditors, representing at least two-thirds of the value of the assets of the class, must vote in favour. The ability to define the classes is thus a powerful tool. Under CCAA, it is the incumbent management, under the general guidance of the Court to group like creditors together, which gets to make the initial proposal. Even when appeals to the Court cause the initial design to be varied, the variances are normally only just enough to satisfy a judge's sense that a particular creditor has not been treated unjustly. In practice, the management proposal will avoid creating any more classes than necessary, since each wields a veto, and may have elements of gerrymandering, in the sense that designing class memberships so as to distribute probable objectors more or less evenly is much to be desired from the point of view of the sitting management.

Debtor-in-possession finance. Under CCAA, by definition the assets of the failing firm, including its shareholders' equity, are insufficient to satisfy obligations to creditors as they fall due. Under such circumstances the claims of all creditors are impaired, in accordance with the statutory priorities. No rational lender would step forward unless, at the 
least, his new loans were granted a super-priority over all existing claims. It is in the interest of existing creditors to grant that superpriority if so doing raises the probability that an injection of new funds will make all creditors better off. It is in the interest of society as a whole to grant super-priority if the new funds mean that the sum of creditor losses and external costs are likely to decrease - an important distinction. That is why a Court is called on to decide the issue, as the interests of the creditors and those of society at large may diverge. In such a case, the magnitude of the difference and the probability with which it may occur become important considerations, as the Court may be called upon to act against at least the short-term interests of the creditors.

Air Canada, working in necessary secrecy in the days before its filing, arranged \$954 million in debtor-in-possession financing from an affiliate of GE Capital Corporation. Later, it sold Aeroplan loyalty points to CIBC, a Canadian bank, for $\$ 350$ million.

Disclaiming collective agreements. In US practice, filing under Chapter 11 gives management a discretionary right to unilaterally modify or even abandon collective agreements with unions. Wages may be lowered, benefits and pension rights abrogated, and work rules changed to promote efficiency. CCAA contains no such automatic provision. The presiding judge may, in extreme circumstances, approve a company's application to set aside a collective agreement, but the matter is contentious and only used with great reluctance and as a last resort.

In the Air Canada case, any of seven unions could, by failing to agree to its share of the pain, bring down the whole house of cards. Mr. Justice Farley opted not to repudiate the agreements but rather to appoint a fellow judge, Mr. Justice Warren Winkler, to preside over marathon last-minute negotiations, reserving the threat of direct intervention if unions and management failed to find a solution acceptable to the new investors. The combination of threat and suasion - Justice Winkler appears to have been at least as tough, behind closed doors, as Justice Farley is in the courtroom - eventually worked, but not until three days after the 'deadline' imposed by DB and GECAS, the major new investors. 


\section{Some lessons}

Lessons for policy. A workable bankruptcy regime is fundamental to any market economy. Business failures are inevitable, and there needs to be an efficient process for recycling the economic assets involved. To the degree that the system is not equitable, swift, predictable in outcome, and proof against predatory behaviour by persons wishing to exploit the system as part of the market in corporate control, the price of capital for all firms will rise. Such unnecessary risk poses a deadweight burden on the entire national economy as the price of credit rises to an unhealthy new equilibrium.

In the Air Canada case, the system appears to be working well. A reorganized Air Canada is scheduled to emerge from creditor protection on September 30 with reasonable prospects, in the views of the creditors most concerned, of success thereafter. Some $\$ 9$ billion in debt will be cut by more than half, new equity of $\$ 1.1$ billion raised, new aircraft financed within the new debt structure, and costs will have been substantially lowered. The former shareholders will get nothing, and the former directors will be fired. The new owners - once and future creditors, for the most part - will have decided to keep the present managers in place, apparently judging that they were not entirely responsible for the 2003 insolvency and cannot be immediately replaced by demonstrably superior ones.

The system worked in other senses, too. The 2000 bid for CAIL involved politically well-connected people. Unperturbed, a fearless Court dismissed the bid for failing to respect the plain language of the law, and the politicians did not try to trump the judgment by changing the rules in the middle of the game. The Court also demonstrated the desirability of a statute with sufficient flexibility to allow an unconventional ruling based on a balance of risks, as in the case of Mr. Justice Farley's allowance of a super-priority for the Lufthansa code-sharing arrangement.

Finally, the system worked in the government's favour as well. By refraining from subsidy or nationalization the government kept management, financiers and unions at the bargaining table. Only when it became clear, for example, that the government was not going to socialize the pension obligation that the unions finally bargained in earnest. In sticking to its role as designer of the bankruptcy system the govern- 
ment attained its greatest and paradoxically least visible victory: the continued assurance to capital markets that Canada had a wellfunctioning system and that lenders would not have generally to increase credit costs across the whole economy.

Political restraint aside, the elements of success, in summary, are the following.

Competent supervision. Less-than-zero-sum games require strong referees. The judicial system in Canada produces competent, independent, and apparently incorruptible judges. Appointments to all the superior courts are made by federal order-in-council - in practice, by the prime minister on the recommendation of the attorney general and minister of justice, following advice from the bar and senior public servants in the Department of Justice. Once appointed, they are free of political constraint, as they may serve until 75 . They may be removed only by a resolution of both Houses of Parliament, following censure by the Canadian Judicial Council, which is composed of the Chief and Associate Chief Justices of the provinces and the Chief Justice of the Supreme Court of Canada. Judicial salaries are set by independent commissions to avoid even the impression that governments could affect outcomes by withholding pay. These salaries place judges in the top two to three percent of Canadian incomes - not, perhaps, as much as senior partners in large law firms might make, but more than enough for a comfortable life, and with a generous pension on retirement. The social prestige that attaches to being a judge is worth forswearing the very highest incomes, at least for a sufficient number of lawyers, and is itself a strong incentive to maintaining probity.

Under the BIA, as noted, the Office of the Superintendent of Bankruptcy licenses trustees, regulates their behaviour ${ }^{261}$, and sanctions malfeasances. Nor is this done privately: all sanctions are published for the world to $\mathrm{see}^{262}$. Parties aggrieved by trustee improprieties may complain to the Superintendent, who has a duty to investigate, and ultimately to the Court. Trustee fees, as well as the salaries of officials in

\footnotetext{
${ }^{261}$ Office of the Superintendent of Bankruptcy Canada, Code of ethics for trustees in bankruptcy, Ottawa, 2000; see also http://osb-bsf.ic.gc.ca.

${ }^{262}$ The OSB Newsletter, published twice annually, publishes summaries of cases dealing with professional conduct matters. The full texts are available under the heading "Trustees" and the sub-heading "Licencing and professional conduct" on the website noted above.
} 
the Office of the Superintendent, are sufficient to provide a comfortable living.

Transparency. The power of a free press, abetted by rules of procedure that require all actions under the CCAA to be open to the scrutiny of interested parties and ultimately the public, is fundamental to maintaining probity. In the Air Canada case, the details of restructuring proposals, the actions of various parties, and the outcomes of negotiations on such matters as collective agreements were reported frequently to the Court by the monitor, and were published instantly on the web. Even minor excursions from lawful propriety would be seized on by one party or another, and would become matters of public notoriety through the press very quickly. As most of the players in this drama, notably banks, accounting consultancies, judges and other officers of the court, and even company directors value their reputations for probity beyond any conceivable pecuniary advantage in a given case, the incentives for good behaviour are strong.

Timeliness. The melting away of the remaining corporate assets during a prolonged insolvency proceeding constitutes a large economic risk. The credit of the firm is necessarily impaired, notwithstanding the stay of proceedings. Old suppliers restrict credit, and new ones do not come forward. Employees, led by the most capable and marketable, consider leaving for more secure situations. Customers find alternative carriers. Time is of the essence in a successful bankruptcy regime. In the Air Canada case, Mr. Justice Farley granted stays under the CCAA for limited periods, always threatening to lift the stay and open the company to liquidation by its creditors if progress toward restructuring was insufficiently swift. The pressure on all parties was unrelenting. There were no days and few nights off for the parties. Even so, the airline has operated under CCAA for fifteen months at this writing, and is not scheduled to emerge until September 30, 2004. Eighteen months is not long by the standards of Chapter 11, however, which perversely offers some comfort to lenders and commercial partners of Air Canada. The complexity of the case has been a matter of daily proof in the press, and the experience of US airline bankruptcies has given observers of the present case a sense that reasonable outcomes are not unlikely.

Predictability of outcomes. A good bankruptcy system must offer all concerned parties an ability to predict outcomes and thus to arrange 
their own affairs in the most advantageous way possible in the circumstances. This is as true with the myriad details of the process as it is with the overall case itself. If a creditor knows that there is an objective and Court-supervised process for compromising his rights equitably with those of others in his circumstances, if the priority of creditors is known and unchallengeable, if there is light at the end of the tunnel in terms of equity for compromised debt (or in the limit in terms of a dividend from the bankrupt estate), then market players will be content to let the process unfold in a rational manner. In the Air Canada case, the predictability of process and outcomes meant that collapse during restructuring was much less likely. From a public policy point of view, there is much value in a legal process that is allowed to accumulate precedents over a long period of time. Overly frequent or radical changes in the basic procedure may cause years of heightened uncertainty. It is in this sense that a government that can restrain itself from intervening even (or especially) in notorious and embarrassing cases is helping to improve long-term confidence and keep down the cost of credit generally.

Balance between liquidation and reorganization. There is no doubt that in large cases with substantial externalities the mood of the times has swung away from the debtor-friendly UK laws of 1904 and 1919 toward regimes that give every opportunity for the survival of a reorganized company. Small bankruptcies, however, pose few such external costs. The continued co-existence, as the Senate Committee recommends, of the BIA and the CCAA thus accords with economic common sense. The BIA handles small business and consumer cases efficiently, while CCAA allows judges considerable discretion within a general framework of procedures to design a process that has a high probability of a successful outcome.

Generality of process. Both CCAA and BIA are designed to work with firms in any sector or region. With the small exception of the Winding Up Act for financial institutions, the same legal framework applies to all insolvent companies ${ }^{263}$. This seems appropriate as the fundamentals of

\footnotetext{
${ }^{263}$ The exception is state-owned or Crown corporations that are "agents" of government i.e., have a public policy purpose that transcends commerce - but as they rely on the "full faith and credit of the Crown," their insolvency is impossible without the prior bankruptcy of the country as a whole.
} 
debt, credit and solvency are quite general, applying to all organizations.

It is hard to draw broad lessons from single cases, but the Air Canada case will likely cause Parliament to reflect on one or two of the reforms being recommended by the Senate Committee, as well as certain established practices. For instance, if the failed management and board are to be left in place during a restructuring, might there not be strictures against conflicts of interest? Trinity Time Investments, the Li equity vehicle, promised large financial rewards - from its own pocket, be it said, not Air Canada's - to Robert Milton and Calin Rovinescu if they were the successful bidders. This raised apprehensions of bias in the preference shown to this bid for some time thereafter. It is not clear that the presiding judge, short of inventing a new aspect of "inherent jurisdiction" under the CCAA, was in much of a position to quash this side deal.

On the other hand, the labour negotiations, while exhausting, were ultimately successful. No fewer than seven different unions had to accept their share of an aggregate of $\$ 1.1$ billion in cost reductions to meet the conditions established by Deutsche Bank and GECAS, the main providers of new capital in the plan of arrangement. In the end past the deadline, after much public histrionics and private hard bargaining, they did. It is to be expected that the details of these new agreements are more acceptable to both sides than an abrogation and redefinition by one side only. Faced with the stark alternative of liquidation the unions bargained for their lives. The case makes it more difficult to argue for importing a Chapter 11-style right of management to repudiate collective agreements.

Air Canada's reorganization is not yet complete. A number of steps remain to be taken, any of which could in principle imperil success or push back the forecast completion date of September 30, 2004. Nevertheless the main steps have been taken.

\subsection{Matters of special interest in Russia}

In general, how is probity assured? How are the interests of all parties, including owners, assured? The proximal answer is that disinterested professionals are interposed between creditors and debtors: trustees, judges and receivers. Strongly reinforcing the probity of these 
professionals is the extensive transparency afforded bankruptcy cases, with forced disclosure of relevant information to all parties, the involvement of all creditors on a committee and the delegation of some of their powers to inspectors. Simply put, there are too many players involved in a corporate bankruptcy to allow improper behaviour to pass unnoticed.

How are receivers and trustees regulated? A senior federal official, the Superintendent of Bankruptcy, whose office has extensive and detailed oversight of trustee activities, regulates trustees. The Superintendent establishes standards for the training of trustees, examines them, grants licenses as long as their professional qualifications continue to meet the established standards, hears complaints and where necessary takes disciplinary action.

How are priorities for the distribution of bankrupt estates established? These contentious priorities, including those of the state itself, are established by Parliament under Section 136 of the BIA.

Has an insurance fund been considered to protect certain classes of creditors from malfeasance by regulated officials? No; in such a case, a creditor would have a claim against the tortious official, and perhaps against the Superintendent if there has been negligent oversight. If malfeasance is by a civil servant the Crown may be sued. There has from time to time been consideration of a special fund, perhaps an offshoot of the Employment Insurance scheme, which would bear the costs of a super-priority to unpaid wage claims, but that is another matter. Malfeasance of this kind is quite rare.

How are insolvent state corporations dealt with? If such corporations are "agents of Her Majesty," the normal case, they operate with the full faith and credit of the state. Insolvency is thus impossible in principle, as there is no end to the credit that will be extended in such a case. In practice, the federal Treasury Board Secretariat and Department of Finance exercise sufficient controls over Crown corporations that threatening situations are dealt with before they become dangerous. Two examples: when the federal government privatized the Canadian National Railway in 1996 it was necessary to "clean up its balance sheet" quite substantially before a reasonable sale could be concluded. And the concentration of exposures on the books of the Export Development Corporation is such that it is unlikely that it could borrow at rea- 
sonable rates without reliance on the financial resources of the government as a whole.

There are a small number of cases where the government owns a company or an interest in a company that is expressly declared not to be an agent. In such cases the ordinary procedures of the BIA or CCAA would apply. Needless to say, this would be an embarrassment, so reasonable oversight is maintained to ensure that problems are dealt with before they become notorious.

Are particular sectors dealt with differently? Companies with more than $\$ 5$ million in liabilities may use the provisions of CCAA or the BIA, but not both. All others, with the exception of financial corporations who would use the Winding Up and Restructuring Act, must use the BIA. Other than that, no distinctions are made on a sectoral, geographical, or sole-employer basis.

Do the provinces play any role? Section 91(21) of the Constitution Act, 1867 assigns bankruptcy exclusively to the federal government. However, it also assigns matters of property and civil rights to the provinces. Where they tend to meet is in respect of the exemptions from seizure in personal bankruptcies, where individual provinces (as states in the United States) may have somewhat different lists, and in some of the broader aspects of creditor-debtor law. In these cases, courts will defer to the law most closely related to the constitutional basis on which it is erected. A large volume of case law provides a high degree of certainty.

Provinces will act as any interested creditor group when priorities are at issue in legislative amendments. They sought and won a superpriority for environmental damage in 1997, and insist that their other Crown super-priorities rank pari passu with the federal government. Their protection does not, however, extend to their legislative creatures the municipalities, who must take their place in the dreary queue of ordinary creditors.

What about international conflicts in law and the recognition of foreign bankruptcy decrees? This is a matter of evolving practice, principally involving trans-border bankruptcies where assets are located in both the US and Canada ${ }^{264}$, although other genuinely multi-national

\footnotetext{
${ }^{264}$ The US side has given attention to practical procedures for such cases: cf. American Law Institute, Transnational Insolvency Project, "Principles of cooperation in transnation-
} 
cases, such as those of the airlines, have been testing the framework lately. Under the BIA/CCAA reforms of 1997, the steps courts had been taking on a case-by-case basis to recognize and coordinate with procedures in other countries received statutory blessing. Canada has been an active participant in the United Nations Commission on International Trade Law (UNCITRAL) and its proposed model law on international insolvencies may be adopted soon, perhaps on a basis of reciprocity.

What are the responsibilities of parent corporations toward failing subsidiaries and their creditors? In general, these are defined as matters of contract law. The creditors of a failing subsidiary cannot call on the resources of the parent absent an explicit guarantee; indeed one of the reasons for elaborate corporate group structures is to isolate certain risks. Project finance agreements, for example, usually specify limited or no recourse beyond the resources of the project itself.

As a matter of good corporate governance, of course, a parent corporation would normally exercise such oversight over the activities of a subsidiary as to take corrective measures before a risky situation descended into bankruptcy. For most companies, reputational risk is consciously planned for.

What are the personal liabilities of directors and officers of a company that is insolvent or in the vicinity of insolvency? Directors are liable during a bankruptcy for unpaid wages, unremitted payroll deductions for taxes, Employment Insurance and the Canada Pension Plan, and for dividends paid or other transactions that do not meet a financial test if the company is insolvent. For all these matters a due diligence defence is available and would normally be covered by an indemnity from the company or by standard Directors' and Officers' liability insurance. Directors are also liable for many other items in the ordinary course of business ${ }^{265}$, but these are the special ones that are likely to arise in the context of a bankruptcy.

als insolvency cases among the members of the North American Free Trade Agreement," Philadelphia, 2000.

${ }^{265}$ McCarthy Tetrault, Directors' and officers' liabilities in Canada, Butterworths, Toronto, 1997. 


\section{Annex A: The ten acts of bankruptcy}

According to Section 42 of the BIA, a debtor company commits an act of bankruptcy if, in the six months before the filing of the petition:

- in Canada or elsewhere it makes an assignment of its property to a trustee for the benefit of its creditors generally, whether it is an assignment authorized by the Act or not;

- in Canada or elsewhere it makes a fraudulent conveyance, gift, delivery, or transfer of its property or any part thereof;

- in Canada or elsewhere it makes any conveyance or transfer of its property or any part thereof, or creates any charge thereon, that would under this Act be void as a fraudulent preference;

- (for individuals:) with intent to defeat or delay its creditors, he departs out of Canada, or, being out of Canada, remains out of Canada, or departs from his dwelling-house or otherwise absents himself;

- the debtor permits any execution or process issued against the debtor under which any of the debtor's property is seized, levied on or taken in execution to remain unsatisfied until within five days from the time fixed by the sheriff for the sale thereof or for fifteen days after the seizure, levy or taking in execution, or if any of the debtor's property has been sold by the sheriff, or if the execution of other process has been held by the sheriff for a period of fifteen days after written demand for payment without seizure, levy or taking in execution or satisfaction by payment, or if it is returned endorsed to the effect that the sheriff can find no property whereon to levy or to seize or take, but where interpleader proceedings have been instituted with respect to the property seized, the time elapsing between the date at which the proceedings were instituted and the date at which the proceedings are finally disposed of, settled or abandoned shall not be taken into account in calculating the period of fifteen days;

- it exhibits to any meeting of its creditors any statement of its assets and liabilities that shows that it is insolvent, or presents or causes to be presented to any such meeting a written admission of its inability to pay its debts; 
- it assigns, removes, secretes or disposes of or attempts or is about to assign, remove, secrete or dispose of any of its property with intent to defraud, defeat or delay its creditors or any of them;

- it gives notice to any of its creditors that it has suspended or is about to suspend payment of its debts;

- it defaults in any proposal made under this Act; and

- it ceases to meet its liabilities generally as they become due.

Since 1997, the suspension by a regulatory authority of a securities firm for capital inadequacy has constituted an eleventh act of bankruptcy.

As any of these acts are criminal in nature, the onus of proof lies on the petitioning creditor(s), and the judge must hold a hearing on the proof of statements in the petition if the matter is opposed.

\section{Annex B: Powers and liabilities of trustees under the BIA}

The function of the trustee is to take possession of the deeds, books, records and documents and all property of the bankrupt as quickly as possible... and to make an inventory of all of the property of the bankrupt. The trustee should change the locks on the bankrupt's property and redirect mail and in this regard, the trustee is in the same position as if he were a receiver of the property of the bankrupt appointed by the court. In addition, the trustee possesses various remedies to recover property of the bankrupt that is in the hands of third parties [...subject to] the rights of secured creditors... [A] trustee in bankruptcy may not oust a receiver appointed by a creditor with valid security.

Once the trustee has gathered in the property of the bankrupt, the trustee is obliged to realize upon it and distribute the proceeds to the creditors of the bankrupt in accordance with the priority of distribution established in the BIA.

Prior to the first meeting of creditors, the trustee may dispose of property that is perishable or is likely to depreciate rapidly in value and may carry on the business of the bankrupt.

Subject to such extension as the court may grant, it is the duty of the trustee to prepare a list of creditors as soon as possible after the bankruptcy and, within five days after the trustee's appointment, to send to creditors and the Superintendent notice of a first meeting of creditors 
which in turn is to be held within twenty-one days of the trustees appointment. At their first meeting [chaired by the Official Receiver], the creditors will vote upon the appointment of at least one and up to five inspectors of the estate of the bankrupt. The inspectors provide advice and directions to the trustee, subject to the authority of the creditors at a meeting or the bankruptcy court to override such directions...

Following the first meeting of the creditors the trustee can, with the permission of the inspectors, sell the property of the bankrupt, lease real property, carry on the business of the bankrupt, bring or defend any action or other legal proceedings relating to the property of the bankrupt, engage a solicitor or agent to conduct business sanctioned by the inspectors, accept security from debtors of the estate, incur obligations, borrow money and give security on the property of the bankrupt, compromise debts and claims, divide property among the creditors which cannot be easily sold, elect to retain, assign, surrender or disclaim any lease of any property of the bankrupt and appoint the bankrupt to aid in the administration of the estate on such terms as the inspectors may direct.

In carrying on the business of the bankrupt, it is possible for the trustee to incur personal liability. For this reason, trustees will normally contract in their capacity as trustees only, and specifically stipulate that they are not acting in their personal capacity. However, not all personal liability can be contracted out of...

The trustee is not personally liable for environmental damage occurring before the trustee's appointment or after the appointment unless it was the result of the trustee's failure to exercise due diligence; but, the trustee is obliged to make any report or disclosure required by federal or provincial legislation.

The bankrupt or any of the creditors or any other person aggrieved by any act of the trustee can apply to the court and the court may confirm, reverse, or modify the act complained of; but, the trustee is protected by the court against improper, frivolous and vexatious suits or proceedings arising out of the administration of the estate.

If a trustee refuses or neglects to take any proceeding which a creditor requests the trustee to take...the creditor may obtain from the court an order authorizing the creditor to take the proceeding in the creditor's name and at the creditor's expense. In order to take such a step, all 
other creditors of the bankrupt must be afforded an opportunity to participate in the proceeding. The fruits of such a proceeding, if any, belong to participating creditors to the full extent of the claim after expenses. The balance, if any, reverts to the estate.

A trustee is a private professional. As such, it is up to the creditors to strike a bargain over fees and expenses, which are paid out of the estate and therefore reduce the creditors' recovery. As trustees' risks and liabilities can be large and only partly mitigated by insurance, itself not cheap, their fees can be considerable. In this respect, the limitation of environmental liability in the 1997 amendments played an important role in moderating fees, and indeed in persuading trustees to take on certain cases at all.

\section{Annex C: Statutory priorities in business insolvencies}

Section 136 of the BIA establishes the following priorities for the distribution of money from the bankrupt estate. All claims of a higher class are paid before any claims of the next class.

1. Super-priorities:

(a) Compensation to the Crown for the costs of environmental damage.

(b) Unremitted wage deductions for Canada Pension Plan and employment insurance premiums, and for employee tax withholdings.

(c) Fees and expenses of the trustee.

2. Secured creditors.

3. Preferred creditors.

(a) Funeral expenses of the bankrupt, if applicable.

(b) Costs of administering the bankruptcy (trustees' fees and legal expenses).

(c) Levy on all estates to help defray the expenses of the Office of the Superintendent of Bankruptcy.

(d) Wage claims up to $\$ 2,000$, plus $\$ 1,000$ in salesmen's expenses.

(e) Alimony and maintenance claims.

(f) Municipal taxes.

(g) Landlords' claims for rent.

(h) Costs of the creditor who first executed against the debtor, and 
(i) Claims of workers not covered by Workers' Compensation.

4. Ordinary (other unsecured) creditors.

5. Preferred shareholders.

6. Common shareholders. 


\section{Conclusion}

The problem of protecting the rights of both the debtor and the creditors during the effectuation of bankruptcy procedures has a fundamental importance in terms of promoting the investment activity of Russian enterprises. Thus problem must be solved on a comprehensive basis, within the framework of the protection methods developed in the sphere of law of obligations (indirect protection of property rights), corporate law, bankruptcy procedures, tax regulation, and execution proceedings.

The threat of an enterprise's bankruptcy and the transfer of control to its creditors have traditionally represented the most important instrument for protecting the rights of the latter. Nevertheless, the application of the institution of bankruptcy for asset seizure, the special role of the State as a creditor, the traditions of soft budget constraints, the socio-political barriers in the way of implementing genuine bankruptcy procedures in respect to loss-making enterprises (especially to large or forming company towns), the numerous technical difficulties associated with an objective estimation of the financial status of potential bankrupts, and corruption have all been the reasons why legislation, as it emerged in the 1990s and the early 2000s, had low efficiency.

It is, nevertheless, necessary to admit that there exist no perfect laws capable of immediately eliminating one or other problem. Specialists in the sphere of law note that the regulation of insolvency represents a most dynamically developing area of law in developed countries, where the national economies necessitate continual updating of certain norms. Thus, in objective terms, a similar approach becomes even more inevitable for Russia's economy in transition.

\section{Economic and institutional aspects}

By now, all the basic elements of the institution of bankruptcy have already come into being in Russia.

Nevertheless, the existing institution of bankruptcy, despite a rather rapid growth in the number of bankruptcy cases, is still very "pinpointed' as regards the scale of its application. Therefore, it cannot solve on the macro-level the problem of withdrawing inefficient enter- 
prises from the market and that of repaying the debts due to creditors (though the character of this institution is explicitly pro-creditor). This situation has resulted from heavy indebtedness of enterprises to the State and from the low predictability of bankruptcy procedures. In general, the institution of bankruptcy does not ensure any predictable distribution of risks for the creditors.

While referring to the "pin-pointed" application of bankruptcy procedures, it is necessary to take into consideration the significant hidden role played by the institution of bankruptcy in safeguarding payment discipline. The very possibility of petitioning to a court of justice that a debtor be deemed to be bankrupt has become an efficient instrument for securing the fulfillment of contractual liabilities.

The scale of application of bankruptcy procedures is dynamically broadening, but the institution of bankruptcy has failed to become a real instrument for achieving the withdrawal of inefficient enterprises from the market and for guaranteeing the repayment of debts to creditors (despite its pro-creditor character). The proportion of unprofitable enterprises is too high for the State to initiate mass bankruptcies of debtor enterprises. At the same time, despite all the shortcomings of the application of the institution of bankruptcy, we cannot share the widespread "catastrophic" view of bankruptcy as the sole source of all evils. Within the framework of corporate law alone, there occur many more violations and abuses in absolute terms than those associated with the said institution.

In general, in the years 2000-2002 the institution of bankruptcy was rather actively made use of by the State. At that time, the State, in the person of its tax authorities, was seeking a solution to the problem of eradicating the abandoned enterprises, while in the person of the Federal Service for Financial Recovery and Bankruptcy of Russia - to that of intimidating the debtors to the budgets and those persons who had outstanding debts in other mandatory repayments. In 2002, more than $90 \%$ of bankruptcy petitions regarding debtors was filed by various state bodies. The tax authorities apparently decided not to lose the opportunity still existing in the year 2002 and to apply bankruptcy procedures in order to liquidate "empty" enterprises.

The role played by the Federal Service for Financial Recovery and Bankruptcy (FSFRB) in initiating bankruptcy procedures remained rela- 
tively active. Excepting the bankruptcy petitions filed by the tax authorities, the proportion of petitions filed by the FSFRB with respect to the general amount of petitions concerning "substantive" debtors, according to our estimates, amounted to approximately 30\% in the year 2002 .

As regards non-governmental structures, the institution of bankruptcy found its major use as an instrument for redistributing property, reorganizing enterprises and overtaking control thereof. The first two usages were determined by the dynamic processes of integration, by the necessity to carry out organizational restructuring of the enterprises and by the smaller costs (as compared to other methods) of the application of bankruptcy procedures in order to solve these problems. The third usage had more to do with the existing opportunities for fraud and abuse within the framework of managerial procedures.

The significant shifts towards a greater protection of minority shareholders' rights have provided additional stimuli to the demand for bankruptcies as an efficient instrument for solving various corporate problems ranging from protecting the manager from the owner to carrying out a hostile takeover.

There have been noticed recently a number of new tendencies with respect to the application of the institution of bankruptcy.

Firstly, bankruptcy of debtors is becoming an increasingly important instrument for safeguarding payment discipline and for guaranteeing the compliance of enterprises with their liabilities in respect to payments to the budgets and other mandatory payments. From early 2002 onwards, the State has become more active in the application of bankruptcy procedures to enterprises with arrears of taxes and other mandatory payments. According to our estimates, by early 2003 the procedures in bankruptcy had already "tied up" more than $15 \%$ of enterprises' arrears of taxes, as compared to only 5\% in mid-2001. Thus, there appeared first signs that the State, which had already exhausted the opportunities for restructuring debts, had begun to use the institution of bankruptcy on a major scale as an instrument for safeguarding payment discipline and for leveling-off budgetary restrictions in respect to debtors with arrears of mandatory payments.

Secondly, an increasing proportion of Russian businesses is becoming interested in guaranteeing stable, transparent and predictable conditions for their economic activities. In this connection, the losses 
caused by the shortcomings of the imperfect and unpredictable institution of bankruptcy procedures are being considered as increasingly significant, as compared to the advantages brought about by a seizure of a business.

The results of our analysis of the application of bankruptcy procedures in the year 2003 have made it possible to offer some preliminary remarks concerning the problems associated with putting into effect the new (third) Law on bankruptcy.

1) In the year 2003, there was a sharp reduction in the scale of application of bankruptcy procedures. The number of petitions in bankruptcy dropped by 7.5 times - from 106,647 in 2002 to 14,277 in 2003, while the reduction in the number of petitions accepted for hearing was even greater - by 9.8 times, from 94,531 in 2002 to 9,695 in 2003.

2) Approximately $85 \%$ of such a dramatic decline in the number of submitted petitions resulted from the fact that the tax authorities had almost entirely stopped to petition against absent debtors. In 2003, only 2,129 petitions were filed against absent debtors, as compared to 81251 in 2002. Such was an "effective" consequence of putting in force the norms of the 3rd Law on Bankruptcy, stipulating that bankruptcy procedures be used in respect to absent debtors only if appropriate funds are available in the budget, but the budget for the year 2003, not unexpectedly, did not envisage any expenditures in respect to these purposes.

3) Against the background of a major fall in the number of petitions filed against absent debtors, the decline in the number of petitions concerning "substantive" debtors seemed rather moderate, but in fact was approximately two-fold. The number of cases accepted for consideration after the introduction of observation in the year 2003 amounted to 5351 , as compared to 10739 in the year 2002. In all likelihood, this decline resulted from the tightening of the terms for filing the petitions in bankruptcy. Thus, the "pin-pointed" application of bankruptcy procedures clearly became more visible.

4) In general, the "degree of extraordinariness" of the application of bankruptcy procedures became significantly higher. Outwardly (by the number of the petitions filed and by the proportion of claims to absent debtors), the application of bankruptcy procedures in the year 2003 was resembling, by its scale, the situation witnessed in 1998-1999. 
5) The Law on Bankruptcy has continued to rather successfully "compete" with the Law on Privatization, as far as the liquidation of unitary enterprises is concerned. Though the number of petitions accepted for consideration against "substantive" debtors reduced twofold in the year 2002, as compared to the year 2002, the number of state unitary enterprises regarding which it was decided to initiate proceedings in bankruptcy, did not decline quite so dramatically (from 643 in 2002 to 511 in 2003). According to the Federal Agency for Federal Property Management, as soon as the plans emerge to transform a state unitary enterprise into a joint-stock company, its assets begin to disperse, and the bankruptcy, as a rule, is effected by its own management.

6) The situation in 2003 was not indicative of any substantial shifts in finding solutions to reorganization and rehabilitation problems arising in the course of bankruptcy procedures. Approximately in $70 \%$ of cases, the supervision procedures were culminating in the initiation of the proceedings in bankruptcy. There was a continuation of the tendency towards a reduction in the number and the percentage of decisions concerning the imposition of external administration (547 in the year 2003, against 931 in the year 2002). There was a considerable fall in the number of approved amicable settlements: from 145 in the year 2002 to 54 in the year 2003. At the same time, there was a significant increase in the percentage of refusals to declare debtors bankrupt and in the percentage of decisions to terminate proceedings, which was demonstrative of the increased role played by arbitrage courts in protecting the rights of potentially solvent enterprises. Only due to these factors, the bankruptcy-oriented character of supervision procedures was mitigated to a certain extent.

7) The procedures of external administration proved to be even less relevant to the conclusion of amicable settlements and the restoration of enterprises' solvency. Thus, despite the emergence of additional mechanisms for the preservation of a debtor's business (the 3rd Law on bankruptcy envisages, in particular, the possibility for return from proceedings in bankruptcy to external administration, if there exists a realistic opportunity for restoring solvency, and the possibility of an additional issue of shares in the course of external administration, provided that the debtor's owner has agreed to this measure), it is still doubtful 
whether any positive shifts have actually occurred. The practice of application of bankruptcy procedures in the year 2003 is indicative of the preservation and even strengthening of the tendency of bankruptcy procedures to culminate in bankruptcy proceedings.

8) The authors of the norms envisaged by the 3rd Law on bankruptcy have clearly overestimated the owners' determination to reorganize and develop debtor enterprises. It was assumed that a significant percentage of bankruptcies did not end up "amicably" only because of the owners' inability to repay the debts of an enterprise and to carry out its reorganization. Therefore, the provisions of the 3rd Law on Bankruptcy make the owners of a debtor enterprise one of the participants in the process. Apart from this, the Law specifies the right of the debtor enterprise, its owners and any third parties to discontinue the bankruptcy procedure at any stage on the approval expressed by the bankruptcy commissioner, after repaying the enterprise's debts. The law envisages the introduction of a new reorganization procedure (financial recovery), which is designed, under certain conditions, to preserve the founders' (participants') right to determine the fate of the enterprise in question, even after the proceedings in bankruptcy have been initiated. Nevertheless, all these innovations have not, apparently, been widely applied. The procedure of financial recovery was effectuated only in ten cases.

In our opinion, the practice of applying the 3rd Law on bankruptcy in the year 2003 is a testimony to the inconsistency of the thesis actively debated in 2001 and 2002, according to which bankruptcy procedures create a framework for mass violation of debtors' rights, as well as those of their owners, who are "hampered" in their efforts to reorganize the enterprise and to repay its debts in the course of bankruptcy procedures.

9) In the year 2003, there occurred a sharp rise in the number of applications and complaints within the framework of bankruptcy proceedings, while the level of "disputability" of such cases also went up, which had other reasons beside the "novelty" of the Law on bankruptcy. The provisions of the 3rd Law on bankruptcy have significantly widened the opportunities for filing protests in the course of consideration of bankruptcy cases - for example, there was introduced the right, on the part of representatives of a debtor's owners, of protesting in courts against the demands filed by the creditors. Thus, despite all the intentions 
stated, the 3rd Law on bankruptcy is still rather ambiguous, and permits various interpretations of the principles for determining the demands of creditors.

It should also be acknowledged that the institution of bankruptcy cannot be considered as a stable and efficient mechanism of corporate governance aimed at reorganizing corporate finances and management. Nevertheless, there exist certain objective indications that the 2002 Law on bankruptcy has already been effectively implemented: during one year the State received six times more money than throughout the whole period during which the previous version of the Law was in effect, while the repayment of debts increased from 20 to $60 \%$, and there was also a considerable decline in the number of "orchestrated" bankruptcies $^{266}$.

\section{The general trends in legislation modification}

Some promising, though apparently remote prospects can be associated with the upgrading of judicial practice in general. For example, in order to protect enterprises from any illegal seizure of control over them (or some of their assets) by means of bankruptcy procedures, it is necessary to extend the practice when judicial instances do not apply bankruptcy procedures as a regular instrument designed to achieve debt repayment. Such actions ought to be recognized as law violations in accordance with Article 10 of the RF Civil Code, from which follows the necessity to ensure the transparency of judicial procedures and the responsibility on the part of judges.

In the nearest future it will be necessary to modify the adopted norms in the following three aspects:

1) It is possible to characterize the provisions of the new Law on bankruptcy, which stipulate that, with respect to the demands concerning mandatory payments, the State shall acquire a constituent power equal to that enjoyed by creditors in bankruptcy, but as regards the satisfaction of demands, the former shall be in the same priority (third) as the latter, as generally reasonable. Moreover, as regards the demands concerning mandatory payments, the State has acquired the right to

\footnotetext{
${ }^{266}$ An interview with Chairman of the Committee for Prperty of the State Duma of the RF Federal Assembly V. S. Pleskachevskii. - Upravleniie sobsyvennost'iu, 2004, No. 1, p. 3.
} 
participate in the conclusion of an amicable settlement. Nevertheless, this approach is not free from some considerable drawbacks, either.

Firstly, unless the institution of representatives of the State is significantly extended in respect to bankruptcy procedures, there will occur a sharp increase in the risk of corruption growth, owing to the "trade" in government voices in the course of decision-making at the meetings of creditors, and also in the risk of intensifying the activity of local authorities aimed at carrying out covert nationalization and property redistribution in favor of third parties. As regards the State's participation in the bankruptcy procedures involving economically or socially important enterprises, it seems equally desirable to envisage the establishment of a Board of authorized representatives of the State intended to guarantee a balanced representation of various interests of the State.

Secondly, the State's direct participation in an amicable settlement can considerably increase the risk of an unequal approach to different enterprises. It is necessary to legislatively determine at least the framework conditions on which the State can agree to an amicable settlement. Apparently, it will require the introduction of alterations and amendments to the Tax and Budget Codes.

3) The principles on which the State (its control bodies) bases its decision as to whether to initiate proceedings in bankruptcy are "not transparent" for both the market participants and the control bodies. Given the absence of any criteria for delimiting the range of enterprises in respect of which it is inexpedient for the State to implement bankruptcy procedures, the actions of individual executive bodies of state authority can be characterized as opportunistic and suffering from lack of system when the proceedings in bankruptcy are initiated against a debtor enterprise. Under these conditions, the institution of bankruptcy, on the one hand, loses its role of an instrument stimulating the enterprises to timely settle budgetary payments, while on the other, it significantly increases the risks involved, due to the unpredictability typical of the application of bankruptcy procedures against individual enterprises. Moreover, the absence, in actual practice, of any criteria regarding the initiation of proceedings in bankruptcy by the State leads to the substitution of state regulation by a "regulation" carried out by individual officials, thus extending the basis for corruption on the part of the state apparatus. 
Given the fact that the very criteria for the initiation of bankruptcy procedures have undergone no essential changes, and the State is still capable of filing claims against a substantial proportion of medium-size and large industrial enterprises, it is extremely important for the State to develop its own criteria for the initiation of bankruptcy of debtor enterprises, so that only a limited proportion of industrial enterprises will be affected by the process, thus permitting these criteria to be applied in actual practice without any reservations.

3) The problem of reciprocal indebtedness of the State to enterprises, for example, under a state order, still to a certain degree remains unsolved. In some instances, this became the reason for the emergence of the enterprises' arrears of payments to the budgets.

When concluding a contract of operating under a state order, an enterprise enters into equal civil-law relations with the customer, that is, the State, thus bearing the burden of responsibility when incorrectly estimating the risks associated with non-fulfillment of the contract by the customer. However, the enterprise is not always free in its choice: e.g., in accordance with the Law on the State Defense Order, in the event when there are no candidates for participating in a tender for the placement of a military order, or when no head contractor has been determined by the results of such a tender, the defense order becomes mandatory for state unitary enterprises, as well as for other organizations that are dominating the commodities market or have a monopoly on performing works necessary to implement this defense order. Moreover, the entering in a state contract designed to maintain mobilization capacities is mandatory for all organizations, if the fulfillment of such a contract does not entail any losses. The latter stipulation is purely formal, because the contract's terms, while being initially profitable, later may remain unfulfilled, which happens fairly often.

This problem has not been solved within the framework of the new law on insolvency, either. It seems feasible to augment it by provisions stipulating that authorized bodies or local authorities may not file a creditor's petition to the arbitrage court on behalf of the Russian Federation, the Russian Federation's subject, or a municipal formation in the event when the debtor has debit indebtedness to the budget of the Russian Federation, the budget of the Russian Federation's subject, or the budget of a municipal formation under a state or municipal order, 
and the difference between the amount of the debtor's liabilities to a budget in question and the said debit indebtedness does not exceed an established margin. At the same time, this stipulation would be reasonable only if the obligations pertaining to interbudgetary relations are executed in full, otherwise conflicts become inevitable, in the course of which local authorities will maintain that they have been deprived of any possibilities to settle their debts to the enterprise because of delayed and/or incomplete transfers from the federal budget.

4) The procedures of rehabilitation of debtors envisaged by the 1998 law have proven to be of very low efficiency. In this connection it can be noted that the new law on insolvency has substantially expanded the set of available instruments, as well as improved their "quality" and protection from misuse. However, there remains a number of problems that are worthy of noting.

Firstly, the necessity for the State to participate in bankruptcy procedures considerably distorts the motivations by which each involved party is guided. Therefore, appropriate measures should be envisaged that would help to regulate the outstanding debts of enterprises against their payments to the budgets and other mandatory payments outside bankruptcy procedures. The mechanisms of debt restructuring appear to be efficient enough for this purpose; however, the incentives for applying the restructuring procedure are not equally strong for all the shareholders (owners) of an enterprise. In fact, the decision concerning restructuring at the level of an enterprise may be vetoed by minority shareholders. Also, if at some later stage the State does initiate a bankruptcy procedure, all shareholders will be placed under equal conditions. So, it appears important to set different rights during bankruptcy procedures for shareholders voting "for" and "against" debt restructuring.

Secondly, the new law on insolvency, just as the previous one, contains the norms of pre-trial reorganization that have never yet worked in actual practice (Article 31). The absence, within the framework of the new law on insolvency, of any mentioning of the necessity for the State to envisage appropriate items of expenditure in the federal budget does not mean that these must not be previously determined in the budget. Thus, there emerge the tasks of estimating the minimum amount of expenditures to be envisaged in the budgets for financing pre-trial reor- 
ganizations and including such expenditures in the draft budget. Besides, it is necessary to single out the limited set of those enterprises in respect to which, in the event of an unfavorable situation, the State will resort to pre-trial reorganization, and (most importantly) to preliminarily determine the necessary content of the debtors' liabilities to the State within the framework of pre-trial reorganization.

Thirdly, the new law on insolvency has introduced a new bankruptcy procedure - financial recovery (Chapter 5, Articles 76-92). This procedure can become an important instrument for reorganizing and reforming an enterprise under its owners' control (including the State, as a shareholder). At the same time, attention should be paid to the fact that this procedure may be initiated by the arbitrage court without the creditors' consent (Items 2 and 3 of Article 75, Item 1 of Article 80). However, the plan of financial recovery and the schedule of debt repayment prepared by the debtor's owners are to be approved by the creditors' meeting. It is necessary to fill the following important gap in the law: what are the solutions available in the event of the creditors' meeting's refusal to approve the plan of financial recovery (which can be quite probable if the creditors' meeting is opposed to initiating this procedure).

Fourthly, it is necessary to remove the contradictions between the provisions in Chapter 5 (e.g., Items 1 and 2 of Article 77) and the norms contained in corporate legislation (in particular, the provisions of the Federal Law "On Joint-Stock Companies") designed to protect the interests of minority shareholders.

Fifthly, one of sufficiently efficient mechanisms for preserving the business activity of large enterprises of economic and social importance could become the exchange, during the implementation of bankruptcy procedures, of an enterprise's debts for shares being transferred to the creditors. The previous Law on bankruptcy did not contain any provisions concerning additional issues of shares. Nevertheless, this mechanism was applied in practice, and in some instances the shares of a newly created enterprise (which absorbed debt-free assets of the debtor) were transferred to the creditors, whereas in others the latter received the shares of an additional issue emitted by the debtor.

In accordance with the new law on insolvency (in the part that regulates the new issues of shares during external administration), share- 
holders have the right of priority when purchasing the newly placed shares; the placement is made only by close subscription; the additionally issued shares can be paid for only by money. Thus, the situations when the State is one of the shareholders have not been given due attention. On the one hand, there exist legislative restrictions to the "dispersion" of the State's stake during a new issue of shares. On the other, the State, due to the peculiarities of its status as a legal subject, cannot be duly efficient in making use of its (shareholder's) propriety right to purchase additional shares - the period during which shareholders may execute their propriety right to purchase the shares of an additional issue cannot exceed 45 days from the date on which their placement has begun. As a result, this form of business rehabilitation may be found inefficient in respect to the enterprises in the public sector.

Sixthly, one of the provisions of the new Law on bankruptcy concerning the sale of strategic enterprises during the implementation of bankruptcy procedures is especially noteworthy: in accordance with Item 8 of Article 195 of the new Law, the creditors in bankruptcy and their affiliated persons may not participate in bidding. This provision, while being reasonable in its essence, in specifically Russian situations may give rise to some serious problems when large enterprises go bankrupt.

Under the conditions characterized by a well-developed actual affiliation of the financial structures (including through industrial enterprises), by a high level of concentration of financial resources, and by the presence of large debtor enterprises with numerous different creditors, the range of potential financially prosperous buyers may become quite limited. This can be fraught not only with losses to creditors (including the State, as one of the creditors) when an enterprise is sold at a reduced price, but also with a possible transition (when it is impossible to sell an enterprise as a whole entity) to sales of the enterprise's separate assets. Besides, the process of discovering the affiliation of different persons may become very difficult, quarrelsome and timeconsuming, as the practice of the antimonopoly agencies has shown. This creates still more opportunities for corruption and voluntarism and for disputes arising after the completion of bankruptcy procedures.

At the same time, if the State effectively applies its right (in accordance with the new law) of priority purchase when strategic enterprises are sold, the risks discussed above will become less important. 
Seventhly, the problems relating to a comprehensive financial rehabilitation of several enterprises within the framework of technological chains or an industry, or a region, remain as yet unsolved. Indeed, a successful rehabilitation of one enterprise in some instances may have only a short-term effect, because the inefficiency of certain enterprises may be conditioned primarily not by its intrinsic problems but by the status of its contractors.

Eighthly, one of the efficient forms of maintaining a business may become the sale of an enterprise (as a property entity) to an organization forming a company town. In the previous law, the terms of sale (Article 137) were too burdensome for the buyer, and so this form of reorganization has not become widespread. Therefore, by softening the requirements to the buyer in Article 175 of the new Law on bankruptcy (reduction in the required number of preserved jobs from $70 \%$ to $50 \%$, introducing a limit for such a requirement (a period of three years), increased possibilities of changing an enterprise's orientation), it will become possible to make enterprises forming company towns more attractive in terms of purchasing them as single entities.

At the same time, the formal (non-economic) character of the requirements to the buyer has been preserved. Indeed, a dishonest buyer may slightly reduce the number of personnel, simultaneously dramatically lowering the wages at the enterprise. This, in fact, may result only in the preservation or even in a growth of "hidden" unemployment. Therefore, it is believed necessary to additionally establish a certain framework for changing the enterprise's wages fund as a whole, while expanding the possibilities for job-cutting.

Ninthly, it is necessary to define the peculiarities of the bankruptcy of enterprises forming company towns more precisely (Articles 168176). The "modification" of the criteria for placing enterprises within this category that has actually taken place remains rather disputable. Though the definition of an enterprise forming a company town has been made more strict, the formal approach to this category of enterprises has remained as before. It would be feasible to make use of criteria like the share of an enterprise's total tax payments within the total amount of taxes collected in a given urban entity; the enterprise's dominant status on the commodities market; etc. Besides, the new law on bankruptcy has dramatically reduced the possibilities for reorganiz- 
ing enterprises forming company towns, because the period of financial recovery or external administration can be extended to no more than one year (Article 172), and the terms of even this short-term prolongation have become more strict. At the same time, enterprises forming company towns probably represent one of the most complicated objects in terms of financial recovery.

\section{The law-enforcement practice and the problem of infrastructure}

Although legislation on bankruptcy underwent rather serious changes during the last few years due to the enactment of the new law "On insolvency (bankruptcy)", the latter has failed to provide solutions to all the problems existing in this sphere. Consequently, it would be reasonable even now to make a number of amendments to the present law.

Firstly, it is necessary to introduce certain changes in the procedure of initiating proceedings in bankruptcy as it is established by the Law «On bankruptcy», that is:

1) It would be feasible to further extend the 30-day period during which the creditor in bankruptcy or an authorized agency responsible for monetary liabilities has the right to petition the court, by introducing amendments to Item 2 of Article 7 of the Law "On bankruptcy".

2) It is necessary to consider the issue concerning the imposition of limitations to the settlement of the creditors' claims at the expense of the debtor's property categorized as capital assets, against which bankruptcy procedure can be initiated.

3) The list of juridical persons that can be deemed to be insolvent (bankrupt) consolidated in Item 1 of Article 65 of the RF Civil Code should be revised and brought into agreement with Item 2 of Article 1 of the Law "On Bankruptcy".

Secondly, the Law "On Bankruptcy" has changed the procedure of nomination and activity of bankruptcy commissioners; these norms also need to be further specified and amended; in particular, the following ones:

1) In accordance with Article 20 of the Law "On bankruptcy", it is mandatory that a bankruptcy commissioner must be a member of one of self-regulating organizations. This stipulation in the law, in fact, con- 
tradicts the RF Constitution, wherein Article 30 states that "No one may be coerced into joining any association or into membership thereof". The issue of the constitutionality of this requirement of the law must, in our opinion, be resolved by the RF Constitutional Court.

2) It would be reasonable to expand the list of the grounds on which bankruptcy commissioners may be recognized as having an interest in respect to the debtor or the creditors.

3) Article 45 of the Law "On bankruptcy" must contain clearly determined criteria for estimating the professional skills of bankruptcy commissioners.

4) It is necessary to establish criteria for the filing of objections to the candidates for the job of bankruptcy commissioners by the debtor and the petitioner (representative of a creditors' meeting).

5) It would be advisable to reconsider the norms contained in the Law "On bankruptcy" that determine the procedure liability insurance for bankruptcy commissioners. In particular, the Law should determine what the consequences would be of an instance when a bankruptcy commissioner nominated by the court is unable to pay the sum of insurance on his (or her) own.

Thirdly, one of the essentially new provisions of the new Law "On bankruptcy" is the introduction of a new procedure - that of financial recovery. Presently, this procedure is not sufficiently widespread. Nevertheless, an analysis of the norms consolidated in Chapter V "Financial Recovery" of the Law "On bankruptcy" has led to a conclusion that the application of certain provisions of the Law "On bankruptcy" that determine the procedure of financial recovery may give rise to complications, and therefore they need to be amended.

1) It is necessary to reconsider the provisions consolidated in subitem 3 of Item 2 of Article 75 of the Law "On Bankruptcy", in the part regulating the periods of debt redemption.

2) Amendments are needed to be made to Item 3 Article 75 the Law "On bankruptcy", in order to expand the list of methods for fulfilling obligations.

3) The contradictions between Article 79 of the Law "On bankruptcy", whose provisions envisage that an agreement be concluded concerning the fulfillment of the debtor's obligations, and the norms of Section 6 of Chapter 23 of the RF Civil Code, which do not envisage any 
agreements between the guarantor and the beneficiary, must be eliminated.

4) It is necessary to further elaborate the norm consolidated in Item 1 of Article 69 of the Law "On bankruptcy", in the part that contains the list of violations or the criteria for estimating the violations of the law made by the debtor's director and serving as the grounds for the director's dismissal by the arbitrage court.

5) Item 4 of Article 69 of the Law "On bankruptcy" must be augmented by the provision to the effect that in the event of delegating the director's responsibilities to one of the employees, the said employee must occupy one of the top administrative positions within a given organization. It is advisable to consider the issue of developing more detailed requirements to the employee to whom the court delegates the responsibilities of the debtor's director.

6) Article 69 of the law must be augmented by a provision to the effect that the arbitrage court may delegate the responsibilities of the debtor's director to a given person only with his or her preliminary written consent.

Fourthly, it is also necessary to introduce amendments to certain norms of the Law «On Bankruptcy» that determine the procedure of performing external administration.

1) It is advisable to legally consolidate the definition of interrelated transactions and to establish a finalized list of instances when transactions may be recognized as interrelated.

2) It is necessary, in a legislative procedure, to clearly establish the notion of an indirect alienation or the possibility of an indirect alienation of the debtor's property.

3 ) In order to prevent any violations in the course of managing the debtor's property externally, we believe it necessary to expand the list of instances when a transaction relating to the managing the debtor's property is to be recognized as a transaction with an interest involved.

4) In order to avoid controversial interpretations of the clause "coordination with a creditors' meeting (or a creditors' committee)", we believe that the said clause in Item 4 of Article 101 of the Law "On bankruptcy" must be replaced by "with the consent of a creditors' meeting (or a creditors' committee)". 
5) Item 5 of Article 103 of the Law "On bankruptcy", in our opinion, must be excluded from the law as incompatible with existing legislation and limiting the rights of the founders (or participants) of juridical persons to withdraw from the body of participants (or founders), simultaneously withdrawing their stake (or share) in the debtor's property.

6) It would be feasible to augment the Law "On bankruptcy" by a provision similar to that consolidated in Article 86 of the 1998 Law "On bankruptcy", which stipulates that "in the event when the main type of the debtor's activity shall be performed only on the basis of a permit (or a license), the buyer of the enterprise shall acquire a priority right to obtain the said permit (or license)".

7) Item 2 of Article 110 of the Law "On bankruptcy" should be amended in order to further specify the list of the debtor's administrative bodies to be authorized to make the decision as to including the sale of the enterprise in the plan of external administration.

Fifthly, many of the norms contained in the Law "On bankruptcy" that regulate the procedure of bankruptcy proceedings also need to be further specified.

1) It is necessary to establish a uniform order of priority for satisfying the claims of creditors, as stipulated in Article 134 of the Law "On bankruptcy" and in Article 64 of the RF Civil Code.

2) It is advisable to reconsider the provisions contained in Article 138 of the Law "On bankruptcy" that establish the procedure of satisfying the claims of secured creditors, their priority over other creditors, with the exception of liabilities to the creditors of first and second priority, and the claims that had occurred before the agreement on a secured credit was concluded.

3 ) Item 3 of Article 138 should be augmented by a provision to the effect that the sale of the object that secures a credit may take the form of close bidding in instances envisaged by legislation.

4) It is necessary to make amendments to Article 141 of the Law "On bankruptcy" and to word the provision consolidated in Item 1 of Article 141 , beginning with the phrase "all creditors" as "the creditors the debtor's liabilities to whom shall be secured by the debtor's property".

5) Item 1 of Article 141 of the Law "On bankruptcy" also needs to be made more specific, to the effect that the decision as to replacing the debtor's assets must be made in an ordinary procedure by a majority of 
votes of creditor in bankruptcies and authorized agencies, on the condition that the adoption of the said decision has been voted for by all the debtor's creditors secured by the debtor's property.

Sixthly, it would be feasible to eliminate the gaps in the regulation of the concluding of an amicable settlement as stipulated in the Law "On bankruptcy", that is:

1) The stipulations contained in Item 2 of Article 151 - 154 should be made more specific, to the effect that an amicable settlement is subject to coordination (or approval) by the debtor's administrative bodies.

2) In order to eliminate the possibility of a double interpretation of Item 2 of Article 150 of the Law "On bankruptcy", the said norm needs to be amended, by adding a clause to the effect that decision of a creditors' meeting concerning the conclusion of an amicable settlement is to be considered effective on the condition that it has been voted for by all the creditors entered in the register of creditors secured by the debtor's property.

3) It would be reasonable to specify the definition of the violation of the rights and lawful interests of the persons participating in a bankruptcy, the third parties participating in an amicable settlement, and other persons whose rights and lawful interests have been violated or may be violated by the amicable settlement, as stipulated in Article 162 of the Law "On bankruptcy", by making amendments to the said Article, or by issuing an official interpretation of this norm.

4) We believe it feasible to establish a deadline for an appeal against the court decision concerning the approval of an amicable settlement on the grounds that new circumstances have been revealed.

5) It is necessary to make amendments to Article 165 of the Law "On Bankruptcy", by excluding the provisions stipulating that the arbitrage court may cancel the amicable settlement in respect to certain creditors.

Seventhly, multiple problems are presently arising due to the application of the norms contained in the Law on bankruptcy concerning an absent debtor, and therefore the corresponding provisions of the Law "On bankruptcy" that determine the procedure of filing a petition in bankruptcy against an absent debtor need to be amended, in particular, along the following lines: 
1) The Law "On bankruptcy" should determine the procedural consequences of petitioning that an absent debtor be deemed to be bankrupt in the event of absence of appropriate resources required to finance the bankruptcy procedures.

2) It is necessary to consolidate, in a legislative procedure, the norm stipulating that the actions in bankruptcy against absent debtors initiated before the enactment of the Law "On Bankruptcy" in 2002, concerning which no court decisions as to recognizing such debtors as bankrupt have been issued, are to be abated directly in accordance with the Law "On bankruptcy".

3) It would be advisable to legislatively determine the procedure of liquidation and exclusion of an absent debtor from the register of juridical persons in the event when the resources needed to finance the procedure of declaring such a debtor bankrupt will eventually not be found.

4) In order to improve legislation on bankruptcy and liquidation of juridical persons, as well as to spend more economically the resources of the federal budget, it would be reasonable to basically reconsider the concept of liquidation of idle juridical persons and to make it possible to liquidate them in a simplified procedure.

5) With the purpose of eliminating contradictions between the abovesaid norms of the Law "On bBankruptcy", it is necessary to amend it, with specific explanations as to whether the norms that regulate mandatory publication of the information concerning bankruptcy extend to the instances of bankruptcy of an absent debtor, and also which period for closing the register of creditors is applicable in the instance of bankruptcy of an absent debtor.

Eighthly, in order to avoid judicial errors that may arise in the case of bankruptcy of a debtor being liquidated, it would be advisable to amend Article 224 of the Law "On Bankruptcy" by augmenting it with a provision to the effect that a creditor also may have the right to petition the court that the debtor being liquidated be deemed to be bankrupt.

Ninthly, as the practice of bringing to civil, administrative and criminal responsibility for violations of bankruptcy legislation has shown, the norms that regulate it, which are consolidated in Article 10 of the Law "On Bankruptcy", as well as in Article 14.12, 14.13 of the RF Code of Administrative Violations, as well as in Articles 195-197 of the RF Criminal Code are almost never applied, and therefore it 
would be feasible to reconsider all the abovesaid norms not on a fragmentary basis, but as essential concepts.

It should also be noted that despite a number of indisputable achievements, the new law is in principle incapable of providing solutions to a number of cardinal problems existing outside the framework of technical procedures.

Firstly, the granting to the State the same rights as all other creditors enjoy will entail the creation of appropriate infrastructure that would ensure that its interests be adequately represented. It is unlikely that adequate resources will ever be allocated to this end. Therefore, a few hundreds of enterprises will indeed enjoy an improvement in the development of and the control over bankruptcy procedures, but the majority of others will, more probably, face greater corruption and an interest in the buying-up of "the administrative resource". The latter scenario is quite probable also because it would be the easiest for the State to initiate the procedure of bankruptcy, there being no need for the State to confirm its claims in court.

Secondly, the tightening of the rules by which bankruptcy procedures may be initiated will not substantially restrict the processes of property redistribution. This is an objective process, and while it has not been resolved within the framework of the law on joint-stock companies, it will still go on, this time within the framework of execution of judgment.

Thirdly, when introducing specific principles of insolvency in certain specific sectors, the incentives are created for debts being dumped on these sectors. However, when this is not done, social cost becomes too high. Besides, the issue of placing a given enterprise in the category of "natural monopoly", or of enterprises forming company towns, or strategic enterprises, is also quite controversial.

Fourthly, a considerable portion of the proposals concerning legislative reform have resulted not from the imperfection of existing regulation, but rather from the underdeveloped infrastructure for its application. One of the main problems in this sphere is the dependence of the arbitrage courts on local authorities and the inadequate level of qualification of the judges dealing with complicated economic disputes.

Fifthly, many of the changes in legislation on insolvency have been the consequences of a reestimation of certain problems, and therefore 
some of the norms contained in the new law on insolvency have been as yet only rarely applied.

According to the EBRD's estimates, a rapid bankruptcy procedure makes it possible to avoid delays which could be damaging in respect to both the debtor and the creditors, as well as to avoid overloading the judicial system. A most essential goal for the transitional economies of the Central and Eastern Europe and the CIS is to eliminate, in their legislations on bankruptcy, all the norms that may impede the realization of the rights of the debtor and its creditors. Nevertheless, as the available estimations have demonstrated, legislation on bankruptcy procedures in the countries with economies in transition is not as well-developed as that regulating other spheres of commercial law. This is especially true in terms of efficient application of this legislation. The proceedings in bankruptcy are often protracted and fruitless. The qualification of nominated external administrators is also questionable. Despite the serious steps that have been taken in these countries in recent years toward improving both legislations and their practical application in the sphere of corporate bankruptcies, no dramatic improvement has been seen so far.

Important prospects - although, obviously, realizable in distant future - are associated with improving the judicial practice as a whole. For example, in order to protect enterprises from unfair seizures of control over all or some of their assets by means of applying bankruptcy procedures, it is necessary to expand the practice of refusal, on the part of judicial agencies, to apply bankruptcy procedures as a routine measure of debt redemption. Such actions must be treated as law violations in accordance with Article 10 of the RF Civil Code, and both the transparency of the judicial procedure and the responsibility of the judiciary must be ensured.

Accordingly, more time will be needed for the emergence of an appropriate infrastructure and its adaptation to the new legislative norms. Therefore, the possibility of further expansion of the practice of bankruptcy of large potentially attractive enterprises may be quite real. Most probably, during that period the controversial influence of bankruptcy on the economic development will become even more obvious. Additional efforts will be required to develop self-regulating organizations of bankruptcy commissioners. 


\section{Bibliography}

Dmitrii Arefiev. O Federal'nom zakone "O nesostoiatel'nosti (bankrotstve) (On the Federal Law "On insolvency (bankruptcy)" (new version). Posted at www.bpi.ru.

Barsukova N. Padeniie "Komety": bez shuma ne oboshlos' (The fall of "Kometa": not without noise). - Kontinent Sibir', 14 February 2003.

Bekker A. Pogonshchiki slonov (Elephants' shepherds). (An interview with V. Pyl'nev). - Vedomosti, 7.06.2000.

Borodin V. Pravovaia priroda statusa arbitrazhnykh upravliaiushchikh v zakonodatel'stve o nesostoiatelnosti i ptoblema pravosub"iektnosti iuridicheskikh lits (The legal nature of the status of bankruptcy commissioners, as determined in legislation on insolvency, and the problem of the legal personality of juridical persons). - Posted at: www.lawfirm.ru.

Burmistrova T., Karelin A. Bankrotstva v sovremennoi Rossii. Resul'taty i praktika primeneniia (Bankruptcies in contemporary Russia. Results and practice of their application.) - Pravo i ekonomika, 2004, No. 3.

Butrin D. Neupravliaemyi upravliaushchii (Unmanageable manager). Den'gi (Money), No. 32 of 16.08.2000.

V. Vitrianskii. Novoe zakonodatel'stvo o nesostoiatel'nosti (bankrotstve). (New legislation on insolvency (bankruptcy). - Khoziaistvo i pravo. No. 3, 1998.

V. Vitrianskii. Obzor osnovnykh polozhenii federal'nogo zakona "O nesostoiatel'nosti (bankrotstve)". (An overview of the main provisions of the Federal Law "On insolvency (bankruptcy)" - Antikrizisnoe upravleniie, 2003, No. 5-6.

V. Vitrianskii. Puti sovershenstvovaniia zakonodatelstva o bankrotstve. (Ways for improving bankruptcy legislation). - Vestnik VAS RF, No. 3, 2001.

V. Vitrianskii. luridicheskii analiz novykh polozhenii zakona "O bankrotstve", priniatogo Gosudarstvennoi Dumoi. (A legal analysis the new provisions in the Law "On bankruptcy" adopted by the State Duma). Posted at: http://bankr.tsr.ru/proekt2/preview.phptable=arbi_zakon\&id=68.htm on 12.08.2002.

Volkov A., Gurova T., Titov V. Sanitary i marodiory (Orderlies and marauders). - Ekspert (Expert), No. 8 of 1.03.1999. 
Volkov A., Privalov A. Khudshii zakon Rossii (Russia's worst law)"- 2. Expert, 4 March 2002.

Golikova V., T. Dolgopyatova, B. Kuznetsov, Yu. Simachiov (2003). Spros na pravo $v$ oblasti korporativnogo upravleniia: empiricheskiie svidetelstva (The demand for law in the field of corporate governance: empiric strategies). Series "Nauchnye doklady: nezavisimyi ekonomicheskii analiz" (Scientific reports: Independent economic analysis) In: No. 148. M.: Moscow Public Science Foundation. ANO Proekty dlia budushchego: nauchnye i obrazovatel'nye tekhnologii" (Project for the future: science and education technologies), 2003.

Gorelov A. P. Mozhno li primeniat' normy ob otvetstvennosti za prestupleniia $\vee$ sfare bankrotstva.(Can the norms determining the responsibility for crimes in the sphere of bankruptcy be applied.). - Zakonodatel'stvo, 2004, No. 1.

Gorelov A. P. П. Neopredelionnost' norm ob otvetstvennosti za ekonomicheskiie prestupleniia kak neustranimye somneniia $v$ vinovnosti litsa. (The vagueness of the norms determining the responsibility for economic crimes as persisting doubts determining a person's guilt). Adviokat, 2003, No. 2.

Gorelov A. O rossiiskoi spetsifike instituta bankrotstva (On the Russian specificity of the institution of bankruptcy). - Rynok tsennykh bumag, 1998, No 19.

Guev A.N. Kommentarii k UK RF dlia predprinimatelei. (A commerntary in respect to the RF Criminal Code for entrepreneurs). - M.: InfraM-Norma, 2000.

Dannye arbitrazhnoi statistiki za 1998-2003. Vestnik Vysshego Arbitrazhnogo Suda Rossiiskoi Federatsii (The herald of the Supreme Arbitrage Court of the Russian Federation), 1999 No. 3; 2000 No. 3; 2001 No. 4; 2002 No. 4; 2003 No. 4; 2004 No. 5.

Data provided by a survey of enterprises of processing industries, conducted in April-May of 2000. The poll among 438 industrial enterprises was conducted by GfK and ordered by NERA (UK) and Bureau for Economic Analysis.

Report "Preduprezhdeniie bankrotstva: analiz statisticheskikh dannykh za 2003 god (Prevention of bankruptcy: an analysis of statistical data for the year 2003". 
Yegorov A.V. - Nekotorye problemy opublikovaniia svedenii, sviazannykh s bankrotstvom (na primere otsutstvuiushchego dolzhnika). (Some problems associates with the publication of information concerning bankruptcy (as exemplified by an absent debtor). Vestnik Vysshego Arbitrazhnogo Suda Rossiiskoi Federatsii (The herald of the Supreme Arbitrage Court of the Russian Federation), No. 12/2003.

Yen'kov A. Yu. Kommentarii k FZ "O nesostoiatel'nosti (bankrotstve), priniatom na zasedanii Gosdumy 27.09.02" (A commentary in respect to the Federal Law "On insolvensy (bankruptcy)", adopted at the State Duma's session on 27.09.02). Posted at the web site of the Regional Agency for Debt management: http://www.raud.spb.ru.

Yerofeev A. Bankrotstvo: budet li rabotat' novyi zakon? (Bankruptcy: will the new law work?) - Vedomosti, 27 November 2002.

Zavadnikov V. Bankrotnye killery lishatsia raboty? (Killers in bankruptcy will lose their jobs?) - Rossiiskaiia gazeta of 2 November 2002.

Zaiko A. Russkii peredel. Dubl' tri. (Russian repartitition. Take 3). Kompaniia, 22 April 2002.

Zakliucheniie po zakonoproektu "O vnesenii izmenenii i dopolnenii v Federal'nyi zakon "O nesostoiatel'nosti (bankrotstve)". (An estimation of the draft law "On insolvency (bankruptcy)"). Rossiiskoe obshchestvo nezavisimykh ekspertov i antikrizisnykh upravliaiushchikh (Russian Society of Independent Experts and Crisis Managers). February 1999.

Institut bankrotstva stanovitsia vsio bolee vostrebovannym ekonomikoi mekhanizmom (The institution of bankruptcy is becoming a mechanism the demand for which is ever growing in the economy.) An Interview with Head of a Department of the RF Ministry for the Management of State Property Tseren Tserenov. See www.opec.ru.

An interview with Chairman of the Committee for Property of the State Duma of the RF Federal Assembly V. S. Pleskachevskii. - Upravleniie sobsyvennost'iu, 2004, No. 1, p. 3.

An interview with Valerii Nazarov - Head of the Federal Agency for Managing Federal Property. - Vedomosti, 18 May 2004.

On-line conference with Trefilova T., by the "Garant" company, 20 May 2003.

Karpov P. "O prichinakh nizkoi sobiraemosti nalogov (neplatezhei fiskal'noi sisteme), obshchikh prichinakh "krizisa neplatezhei" i vozmozhnosti vosstanovleniia platezhesposobnosti rossiiskikh predpriiatii". 
Otchiot mezhvedomstvennoi balansovoi komissii." (On the causes of low tax collection (non-payments in the fiscal system), the general causes of "the crisis of non-payments" and possibilities of restoring solvency of Russian enterprises. Report of the Inter-Departmental Balance Commissions). Moscow, 1997.

Kats K. Tatiana Trefilova: Zakon tiazheloi sud'by (A hard-luck law)". Gazeta of 14 August 2002; Trefilova T. Vtoroe dykhanie (Second wind). Ekonomika i zhizn', 2003, No. 11.

Kiperman G. Novyi zakon o bankrotstve (The new Law on bankruptcy). - Finansovaia gazeta. Regional'nyi vypusk (Regional Issue). 2002, No. 47.

Komarov Yu. Glavnoe - finansovoe ozdorovleniie (The main thing is financial rehabilitation). (An interview with G. K. Tal'). - Zhurnal dlia aktsionerov (Journal for shareholders), 1998, No. 11.

Kommentarii k UK RF. (A commentary in respect to the RF Criminal Code). Ed. by lu. I. Skuratov, V. M. Lebedev. M.: Infra-M-Norma, 1999.

Kommentarii k Federal'nomu zakonu "O nesostoiatel'nosti (bankrotstve) (A commentary to the Federal Law "On insolvency (bankruptcy)", ed. by V.V. Zalesskii. - M. Izdatel'stvo g-na Tikhomirova M.Yu., 2003.

Kommentarii k Federal'nomu zakonu "O nesostoiatel'nosti (bankrotstve) (A commentary to the Federal Law "On insolvency (bankruptcy)": (detailed and applied), ed. by Popondopulo V.F. - M. 2003.

Kotsiba N. Voprosy antikrizisnogo upravleniia $v$ usloviiakh deistviia novogo zakona o bankrotstve (Issues of anti-crisis administration under the conditions of the new law on bankruptcy being in force). - Vestnik FSFO RF, 2002, No. 10.

Kuznetsov B., Simachiov Yu. Praktika i rezultaty bankrotstva (Practice and results of bankruptcy). In: Rossiskaiia promyshlennost': institutsinal'noe razvitie (Russian industry: institutional development). - M: "TEIS". - 2002.

Kuznetsov N. Ocherednost' udovletvoreniia trebovanii kreditorov. (Priorities of satisfying crediors' claims). Pravo i ekonomika, 2003, No. 6.

Kuznetsov O. A. Fiktivnoe bankrotstvo organizatsii: kollizii grashdanskogo, ugolovnogo i protsessual'nogo prava. (An organization's fictitious bankruptcy: collisions of civil, criminal and procedural law). Sudebno-arbitrazhnaia praktika Moskovskogo regiona (The arbitration- 
court practice of Moscow Region). - Voprosy pravoprimeneniia. 2003, No. 3.

Lambert-Mogilianskaia A., Sonin K., Zhuravskaia Ye. Politicheskie aspekty bankrotstva $\vee$ perekhodnyi period (The political aspects of bankruptcy during transition). - M., Russian-European Center for Economic Policy, 2000

Losev A. Kak zakhvatit' predpriiatiie (How to take over an enterprise). Novaiia gazeta of 21 July 2003.

Medlit' s sozdaniiem effektivnogo mekhanisma bankrotstva opasno. Interv'iu s D. Nokologorskim. (It is dangerous to delay the creation of an efficient mechanism of bankruptcy. An interview with D. Nikologorskii). Rynok tsennykh bumag, 1997, No. 12.

Nabliudenie - novaia protsedura v zakone o bankrotstve. (Supervision is a new peocedure in the law on bankruptcy. - Rynok tsennykh bumag, No. 12. 1999.

Neimysheva N., Trefilova T. "Narushat' zakon dolzhno byt' nevygodno (It must be unprofitable to violate the law)". - Vedomosti, 12 August 2002.

O. Pak'e, R. Seligman. Ugroza bankrotstva i restrukturizatsii (na primere moskovskikh predpriiatii). (The threat of bankruptcy and restructuring (as exemplified by Moscow enterprises) - Predprinimatel'stvo v Rossii, 1997, No. 2.

Petrov D. A. K voprosu o bankrotstve likvidiruemogo doilzhnika. (Concerning the issue of a debtor being liquidated). Zhurnal rossiiskogo prava, No. 3 (87), 2004.

Pleskachevskii V. "Novyi zakon o bankrotstve ne pozvolit kromsat' predpriiatiie za kopeiki (The new law will not allow to dismember an enterprise for kopecks)". - Biuro pravovoi informatsii (Bureau for legal information), (www.bpi.ru), 19.12.2002.

Popov A. V. Finansovoe ozdorovlenie kak novaia protsedura bankrotstva. (Financial rehabilitation as a new bankruptcy procedure. - Zakonodatel'stvo, No. 3, 2003.

Popondopulo V.F. Novelly Zakona "O nesostoiatel'nosti (bankrotstve) (Kratkii kommentarii glav I, II, XII). (Innovations in the Law "On insolvency (bankruptcy)" (A brief commentary to Chapters I, II, XII). - lurist i bukhgalter 2002, No. 4, p. 81. 
Project of the Bureau for Economic Analysis "Napravleniia i faktory restrukturizatsii promyshlennykh predpriiatii" (Areas and factors of restructuring industrial enterpreises) (Project Director - Kuznetsov B. V.).

Pudrov lu. Bankrotstvo likvidiruemogo doilzhnika. (The bankruptcy of a debtor being liquidated), Communication of 21.03.2001 17:43:00, On-line Conference "Bankruptcy", by the Association of Independent Tax Consultants and Internet Auditors of Russia, http://yedelkin.annkiar.ru/conference/messages.asp?IDConf=14\&IDT heme $=46$.

Radygin A. Sobstvennost' i integratsionnye protsessy $v$ korporativnom sektore (Property and integration processes in the corporate sector). - Voprosy ekonomiki, 2001,No. 5.

Radygin A., Entov R. Korporativnoe upravlenie i zashchita prav sobstvennosti: empiricheskii analiz i aktual'nye napravleniia reform (Corporate governance and protection of property rights: empirical analysis and vital areas of reforming). Moscow, 2001.

Radygin A.D, Gontmakher A. Ye., Mezheraups I.V., Turuntseva M. Yu. Ekonomiko-pravovye factory i ogranicheniia $v$ stanovlenii modelei korporativnogo upravleniia (The economic and legal factors and limitations during the consolidation of corporate governance models). M., IET, 2004.

Radygin A. D, Entov R. M., Mezheraups I. V. Osobennosti formirovaniia natsional'noi modeli korporativnogo upravleniia (The peculiarities of the formation of the national model of corporate governance). Naucnye trudy No. 55-R, Moscow, 2003.

Razorionov N. V. Kto krainii pri bankrotstve (Who is the scapegoat in bankruptcy). - Grazhdanin i pravo, 2003, No. 2.

Rubchenko M. Zachekhlit' ne poluchilos' (No success in a coverup). - Expert, 17 December 2001.

Rukhtin S. Pravosposobnost' nesostoiatel'nosti iuridicheskogo litsa. (Legal capacity of insolvency of a juruducal person). - Rossiiskaia iustitsiia, No. 7, 2001.

Samodurov V. Vlast' ne proshchaiet dolgi (The State does not forgive debts). An interview with the Director of the FSFRB of Russia Trefilova T. I. - Muzhskaia rabota, 2003, No 4. 
Sviridenko O. Naznacheniie i tseli instituta bankrotstva v khoziiaistvennom oborote (Designation and purposes of the institution of bankruptcy in economic turnover).- Pravo i ekonomika, 2003, No. 3.

Svit Yu. Vosstanovitel'nye protsedury - sposob predotvrashcheniia bankrotstva. (Rehabilitation procedures - a way of preventing bankruptcy). - Rossiiskaia lustiysiia, No. 3, 1998.

Simachiov Yu. (2003), Institut nesostoiiatel'nosti v Rossii: spros, osnovnye tendentsii i problemy razvitiia (The institute of insolvensy in Russia: demand, main trends and problems of development).- In: Voprosy ekonomiki. 2003, No. 4

Simachiov Yu. Masshtaby i formy gosudarstvennoi podderhzki promyshlennykh predpriiatii, biudzhetnye ogranicheniia na mikrourovne, vliianiie na reformirovaniie biznesa (Scope and forms of state support to industrial enterprises, budget constraints at the microlevel, influence on business reforming). - ASPE Seriia nauchnykh dokladov (Series of scientific reports). M.: Trovant, 2002.

Skliarova I. President nastaivaet na maksimal'nom usilenii roli gosudarstva v protsedure bankrotstva (The President insists on a maximum strengthening of the role of the State in the bankruptcy procedure). Published at www.bpi.ru.

Sonin K., Zhuravskaia Ye. Bankrotstvo v Rossii: ni zashchity kreditorov, ni restrukturirovaniia (Bankruptcy in Russia: neither the protection for creditors, nor restructuring). Spetsial'nyi doklad. Obzor ekonomiki Rossii. Osnovnye tendentsii razvitiia (A special report. An overview of Russia's economy. Main trends of development). 2000. I. Transl. from the English. - M., Russian-European Center for Economic Policy, 2000.

Stepanov V. Nesostoiatel'nost' (bankrotstvo) v Rossii, Frantsii, Anglii, Germanii. (Insolvency (bankruptcy) in Russia, France, England, Germany). - M., "Statut", 1999.

Teliukina M. Osnovy konkursnogo prava (The basics of bankruptcy law). - M., Volters, Kluver, 2004, c.77-82.

Teliukina M. Osobennosti novogo zakonodatelstva o nesostoiatel'nosti (bankrotstve) (The peculiarities of new legislation on insolvency (bankruptcy). - Zakonodatel'stvo (Legislation), No. 5, 1999.

Teliukina M. V. Kommentarii k Federal'nomu zakonu ot 26 oktiabria 2002 goda No 127-FZ "O nesostoiatel'nosti (bankrotstve) (A commen- 
tary to the Federal Law "On insolvency (bankruptcy)" of 26 October 2002 No. 127-FZ. - Zakonodatel'stvo i ekonomika, No. 3-12, MarchDecember 2003. Source - reference law system "Garant".

Teliukina M. V. Prodazha predpriiatia v ramkakh vneshnego upravleniia. Problemy novogo pravogogo regulirivaniia. (Sale of an enterprise within the framework of external administration. The problems of new legal regulation.). - Zakonodatel'stvo, No. 4, 2003.

Ugolovnoe pravo. Osobenaiia chast': uchebnik dlia vuzov. (Criminal law. Special part: A textbook for higher educational establishments). Ed. by I.la. Kozachenko, Z.A. Neznamova, G.P. Novosiolev. - M.: Norma, 2001.

Fedotkin I., Khomiakov V. Rossiiu triasiot bankrotnaia likhoradka (Russia is being shaken by bankruptcy fever). - Moskovskiie novosti, 23-29 April 2002.

Fomin S. (The Federal Service for Financial Rehabilitation and Bankruptcy of Russia today is the only federal agency capable of performing the functions of an empowered body for implementing state policy aimed at realizing the rights of the State as a creditor). - Antikrizisnoe upravleniie, 2003, No. 3-4.

FSFO. Analiticheskii obzor finansovogo sostoiianiia krupnykh, ekonomicheski ili sotsial'no znachimykh organizatsii, podlezhashchikh obiazatel'nomu monitoringu so storony FSFO (An analytical overview of the financial status of large, economically or socially relevant organizations which are subject to mandatory monitoring by the FSFRB of Russia. October 2000.

Khudoleev V. Osobennosti poriadka priznaniia nesostoiiatel'nosti (bankrotstva) predpriiatii i organizatsii (The peculiarities of the procedure for recognizing the insolvency (bankruptcy) of enterprises and organizations. - Konsul'tant buhkgaltera, 2003, No. 2.

Tselibeev S., M. Rozhkova. "'Korund' dostalsia 'Energopromu'" ("Korund" was taken by “Energoprom"). - Vedomosti, 6 June 2003.

Tserenov Ts. "Gosudarstvo stanovitsia real'nym uchastnikom del o bankrotstve (The State is becoming a real participant in bankruptcy cases)". - Expert's Channel, OPEC.RU, 2002.

Tsygichko A. Innovatsionnye pigmei, chlenstvo v VTO i zakonodatel'stvo o bankrotstve (Innovational pygmies, membership in the WTO and legislation on bankruptcy). See www.rsppr.ru, 2001. 
Chernigovskii M. Bankrotstvo zakazyvali ? (Have you ordered bankruptcy?). - Kommersant No. 103/P of 18.06.2001.

Code of ethics for trustees in bankruptcy. - Office of the Superintendent of Bankruptcy Canada Ottawa, 2000.

Yakovlev V. F. O khode realizatsii Federal'noi tselevoi programmy razvitiia sudebnoi sistemy Rossii na 2002-2006 gody, itogakh raboty v 2002 godu i novykh zadachakh arbitrazhnykh sudov. (On the course of the implementation of the Federal target program of the development of Russia's judicial system in 2002-2006, the results of the activity in the year 2002 and the new tasks of arbitrage courts). An address at the Conference of chairpersons of arbitrage courts on 19 February 2003. Vestnik Vysshego Arbitrazhnogo Suda Rossiiskoi Federatsii (The herald of the Supreme Arbitrage Court of the Russian Federation), No. 4, 2003.

Yakovlev V. F. Ob itogakh raboty arbitrazhnykh sudov $v 2001$ godu i o zadachakh po realizatsii sudebnoi reformy i federal'noi tselevoi programmy razvitiia sudebnoi sistemy Rossii v 2002-2006 godakh. (On the results of the activity of arbitrage courts in 2001 and on the tasks relating to the implementation of judicial reform and the federal target program of the development of Russia's judicial system in 2002-2006). Report at the conference of chairpersons of arbitrage courts on 18 February 2002.

Yakovlev V. F. Itogi raboty arbitrazhnykh sudov v 2003 g. Osnovnye zadachi na $2004 \mathrm{~g}$. (Results of the activity of arbitrage courts in 2003. Main goals for 2004.). Shorthand report of the conference of chairpersons of arbitrage courts of the Russian Federation. (11 February 2004).

Yani P. Kriminal'noe bankrotstvo. Bankrotstvo prednamerennoe i fiktivnoe. (Crinimal bankruptcy. Premeditated and fictitious bankruptcy). Zakonodatel'stvo, 2000. No. 3. P. 65.

Aghion P., O. Hart, J. Moore Insolvency Reform in the UK: A Revised Proposal. - "Insolvency Law and Practice" Vol. 11, 1995, pp. 67-74.

Allen F., D. Gale A Welfare Comparison of the German and U.S. Systems. - "European Economic Review", 1995. Vol. 39, pp. 179-209.

Allen F., D. Gale "Comparing Financial Systems" MIT Press: Cambridge, 2000.

Baird D. The Uneasy Case for Corporate Reorganizations. - "The Journal of Legal Studies", 1986. Vol. 15, pp. 127-147. 
Baird D., R. Gertner, R. Picker Game Theory and the Law. - Harvard University Press: Cambridge, Mass, 1998.

Baird D.R. and Morison E.R. Bankruptcy decision making. - J. Law, Econ. \& Org., 17:2 (2001): 366-7.

Baird D.G. and Morrison E.R., "Bankruptcy decision making," J. Law, Econ \& Org., 17:2(2001): 356-72

Bebchuk L. A New Approach to Corporate Reorganizations. - "Harvard Law Review", 1988. Vol. 101, pp. 775-804.

Bebchuk L. "Using Options to Divide Value in Corporate Bankruptcy". NBER Working Paper No. 7614, Cambridge, Mass, 2000.

Beck T., A. Demigı Kunt, R. Levine 2003 Law, Endowments and Finance. - "Journal of Financial Economics" Vol. 58.

Bennett F., Bennett on creditors' and debtors' rights and remedies, $4^{\text {th }}$ ed.. - Carswell, Toronto, 1994, 534.

Bennett F., Bennett on Bankruptcy, CCH, Toronto, $7^{\text {th }}$ ed., 2002.

Bergman Y., J. Callen Opportunistic Behavior in Debt Renegotiations and an Interior Optimal Capital Structure of the Firm Without Deadweight Costs. - "Journal of Financial Economics", 1991. Vol. 28, pp. 109-123.

Berkovich E., R. Israel Optimal Bankruptcy Laws Across Different Economic Systems. - "The Review of Financial Studies", 1999. Vol. 12, pp. 347-377.

Berkovich E., R. Israel, J. Zender Optimal Bankruptcy Law and Firm Specific Investments. - "European Economic Review", 1997. Vol. 41, pp. 487-497.

Berkovich E., R. Israel, J. Zender The Design of Bankruptcy Law: a Case for Management Bias in Bankruptcy Reorganizations. - "Journal of Financial and Quantitative Analysis", 1998. Vol. 33, pp. 441-464.

Birney Earle, "Canada: a case history," in F.R. Scott and A.J.M. Smith, The blasted pine. - Toronto, Macmillan, 1957.

Bloom Richard, "UABT's loss more than triples in 2003". - Globe \& Mail, 16 April 2004.

Brewster Murray, "Air Canada flying solo, Valeri says". - Globe \& Mail, 13 April 2004.

Bolton P., D. Scharfstein Optimal Debt Structure and the Number of Creditors. - "The Journal of Political Economy", 1996. Vol. 104, pp. 125. 
Booth P., P. Hutchison Distinguishing Between Failing and Growing Firms: a Note on the Use of Decomposition Measure Analysis. - "The Journal of Business Finance and Accounting", 1989, pp. 267-271.

Bryant J. Bank Collapse and Depression. - "The Journal of Money, Credit, and Banking", 1981. Vol. 13, pp. 454-464.

Canadian Press, "Air Canada's plan to find new investor gets thumbs up". - Globe \& Mail, 1 May 2004.

Carruthers B.G. and Canada, Consumer and Corporate Affairs, Proposed Bankruptcy Act amendments, Report of the Advisory Committee on Bankruptcy and Insolvency, $2^{\text {nd }}$ ed., Ottawa, 1986.

Claessens S., S. Djankov, D. Klingebiel "Financial Restructuring in East Asia: Halfway There?" in: "Resolution of Financial Distress: An International Perspective on the Design of Bankruptcy Laws" ed. by S. Claessens, S. Djankov, A. Mody. World Bank: Washington, 2000.

Coase R. The Problem of Social Cost. - "Journal of Law and Economics", 1960. Vol. 1, pp. 1-44.

Code of ethics for trustees in bankruptcy. - Office of the Superintendent of Bankruptcy Canada, Ottawa, 2000.

Coricelli F., G.-M. Milesi-Ferreti On the Credibility of "Big Bang" Programs: A Note on Wage Claims and Constraints in Economy in Transition. - "European Economic Review", 1993. Vol. 37, pp. 387-395.

Davis K. An economic analysis of the differences between Canadian and American commercial insolvency laws. - Industry Canada, March 2002, $66 \mathrm{pp}$.

Debtors and creditors sharing the burden: a review of the Bankruptcy and Insolvency Act and the Companies' Creditors Arrangement Act. - Canada, Standing Senate Committee on Banking, Trade and Commerce Ottawa, November 2003.

Delaney K.J. Strategic bankruptcy: how corporations and creditors use Chapter 11 to their advantage. - Berkeley, University of California Press, 1998.

Derek DeCloet, "Air Canada creditors deserve shot in cockpit". Globe \& Mail, 28 April 2004.

Diamond D., P. Dybwig Bank Runs, Deposit Insurance, and Liquidity. "Journal of Political Economy", 1983. Vol. 91, pp. 401-419.

Duncan L. and Honsberger J.D., Bankruptcy in Canada, $3^{\text {rd }}$ ed. - Canadian Legal Authors, Toronto, 1961, ch. 2, pp. 5-14. 
EBRD Transition Reports, 1999-2003. EBRD.

Fisher T.C.G. and Martel J., "Should we abolish Chapter 11? Evidence from Canada," J. Legal Stud, 28(1999): 233-257.

George F. Will, "Always a bumpy ride". - The Washington Post, May 9, 2002, p. A31.

Gilson S., K. John, L. Lang Troubled Debt Restructurings: an Empirical Study of Private Reorganization of Firms in Default. - "Journal of Financial Economics", 1990. Vol. 27, pp. 315-354.

Halliday T.C, "Professionals in systemic reform of bankruptcy laws: the 1978 U.S. Bankruptcy Code and the English Insolvency Act 1986," Am. Bankr. Law J. 74:1(2000): 35-75.

Hart O. "Firms, Contracts and Financial Structure" Clarendon Press: Oxford, 1995.

Hart O., R. La Porta Drago, F. Lopez-de-Silanes, J. Moore A New Bankruptcy Procedure That Uses Multiple Auctions. - "European Economic Review", 1997. Vol. 41, pp. 461-473.

Janet McFarland, "Many good reasons the Li deal didn't fly". - Globe \& Mail, 3 April 2004, A4.

Hotchkiss E. Postbankruptcy Performance and Management Turnover. - "The Journal of Finance", 1995. Vol. 50, pp. 3-21.

Houlden L.W. and Morawetz G.B., The 2003 annotated Bankruptcy and Insolvency Act, Carswell, Toronto, 2002 (annual).

Kaplow Cf. L. Rules versus standards: an economic analysis. -Duke Law J., 42(1992)

La Porta R., F. Lopes-de-Silanes 2001 "Creditor Protection and Bankruptcy Law Reform" in: "Resolution of Financial Distress: An International Perspective of the Design of Bankruptcy Laws" Ed. by S. Claessens, S. Djankov, A. Mody. World Bank Washington.

La Porta R., F. Lopes-de-Silanes, A. Shleifer, R. Visny Legal Determinants of External Finance. - "The Journal of Finance", 1997. Vol. 52, pp. 1131-1150.

La Porta R., F. Lopes-de-Silanes, A. Shleifer, R. Vishny Law and Finance. - "Journal of Political Economy", 1998,. Vol. 106, pp. 11131155.

La Porta R., F. Lopes-de-Silanes, A. Shleifer, R. Vishny Investor Protection: Origins, Consequences, and Reform. - "Journal of Financial Economics", 2003. 
Mas-Collel A., M. Whinston, J. Green "Microeconomic Theory" Oxford University Press: New York, 1995.

Merton R. On the Pricing of Corporate Debt: The Risky Structure of Interest Rates. - "The Journal of Finance", 1974. Vol. 29, pp. 449-470.

Milgrom P., J. Roberts Relying on the Information of Interested Parties. - "Rand Journal of Economics", 1986. Vol. 17, pp. 18-32.

McQueen R., Who killed Confederation Life? Toronto, McClelland \& Stewart, 1996.

Keith McArthur. Air monopoly: how Robert Milton's Air Canada won and lost - control of Canada's skies, McClelland \& Stewart, 2004.

Keith McArthur, "Rival Air Canada bid sees more for creditors". Globe \& Mail, 25 Nov. 2003, B1.

Keith McArthur, "Air Canada seeks rapid approval". - Globe \& Mail, 26 November 2003, B7.

Keith McArthur, "UCC fights Air Canada monitor ". - Globe \& Mail, 7 January 2004.

Keith McArthur, "Air Canada creditors drop bid opposition". - Globe \& Mail, 16 January 2004, B1.

Keith McArthur, John Partridge and Simon Tuck, "Deutsche Bank to share bailout risk". - Globe \& Mail, 26 April 2004, B1.

Keith McArthur, "Cuts take harsh toll on Air Canada employees". Globe \& Mail, 21 May 2004, B1.

Kent Cf. A.F. et al, "Report of the Joint Task Force on business insolvency law reform," Insolvency Institute of Canada and Canadian Association of Restructuring Professionals, March 2002.

McCarthy Tetrault. Directors' and officers' liabilities in Canada. Butterworths, Toronto, 1997.

Ogden J., F. Jen, P. O'Connor "Advanced Corporate Finance: Politics and Strategies".

Partridge John, Paul Waldie, Andrew Willis and Simon Tuck, "Li walks from plan to rescue Air Canada". - Globe \& Mail, 3 April 2004, A1.

Partridge John and Keith McArthur, "GE Capital extends Air Canada Ioan deadline". - Globe \& Mail, 30 April 2004.

Partridge John and Paul Waldie, "Hargrove and Air Canada finally cut a deal". - Globe \& Mail, 21 May 2004, A1.

Partridge John "Air Canada faces new series of critical deadlines". Globe \& Mail, 22 May 2004, B5. 
Partridge John "Air Canada strikes funding deal with "Serberes»: U.S. vulture fund to invest \$250-million". - Globe \& Mail, 24 June 2004, B1.

Prentice Hall: Upper Saddle River, N.J. 2003.

Principles of cooperation in transnationals insolvency cases among the members of the North American Free Trade Agreement. - American Law Institute, Transnational Insolvency Project, Philadelphia, 2000.

Posner R. "Economic Analysis of Law". 5-th ed. A Wolters Kluwer Company, 1998.

Povel P. "Optimal "Soft" and "Tough" Bankruptcy Procedures" Financial Markets Group. Discussion Paper No. 240, London School of Economics: London, 1996.

Ramsay I., "Market imperatives, professional discretion and the role of intermediaries in personal bankruptcy: a comparative study of the Canadian trustee in bankruptcy," Am. Bankr. Law J., 74:4(2000): 399460.

Report of the study committee on bankruptcy and insolvency legislation (TassŭReport), Canada, Department of Justice Ottawa, 1970.

Report on the operation and administration of the Bankruptcy and Insolvency Act and the Companies' Creditors Arrangement Act. - Canada, Industry Canada, Corporate and Insolvency Law Policy Directorate, Ottawa, September 2002; posted in July 2003 at website http://strategis.ic.gc.ca/epic/internet/incilp-pdci.nsf/vwapj/3040Bankruptcies.pdf/\$FILE/3040-Bankruptcies.pdf.

Roland G. "Transition and Economics: Politics, Markets, and Firms" The MIT Press: Cambridge, Mass, 2000.

Sean F. Dunphy, "Bankruptcy and insolvency, reorganization and winding-up," chapter 12 in M.E. Grottenthaler, ed., Doing business in Canada Stikeman. - Elliott, Montreal, 1997.

Skeel D.A., Jr., Debt's dominion: a history of bankruptcy law in America - Princeton University Press, 2001.

Spier K.E. Settlement with multiple plaintiffs: the role of insolvency. J. Law, Econ. \& Org., 18:2(2002): 295

Stiglitz J. Information and the Change in the Paradigm in Economics. "American Economic Review", 2002. Vol. 92, pp. 460-501.

Rubinstein A. Perfect Equilibrium in a Bargaining Model. - "Econometrica", 1982. Vol. 50, pp. 97-110. 
Von Thadden "Optimal Liquidity Provision and Dynamic Incentive Compatibility" Center for Economic Policy Research. Working Paper. London, 1995.

Waldie Paul, "Air Canada, Lufthansa deal approved despite objections," Globe \& Mail, 18 December 2003, B20.

Waldie Paul "«Westjet» banned from using information." - Globe \& Mail, 16 April 2004.

Warner J. Bankruptcy Costs: Some Empirical Evidence. - "The Journal of Finance", 1977. Vol. 32.

Weiss L. Bankruptcy Resolution: Direct Costs and Violation of Priority of Claims. - "Journal of Financial Economics", 1990. Vol. 27, pp. 285314.

White M. Corporate Bankruptcy as a Filtering Device: Chapter 11 Reorganizations and Out-of-Court Debt Restructurings. - "Journal of Law, Economics, and Organization”, 1994. Vol. 10, pp. 268-295.

Wruck K. Financial Distress, Reorganization, and Organizational Efficiency. - "Journal of Financial Economics", 1990 Vol. 27, pp. 419-444.

\section{Websites}

http://www.bpi.ru

http://bankr.tsr.ru

http://yedelkin.annkiar.ru

http://www.lawfirm.ru

http://www.raud.spb.ru

http://www.opec.ru

http://www.bankrot.ru

http://laws.justice.gc.ca

http://osb-bsf.ic.gc.ca.

http://strategis.ic.gc.ca

http://www.stikeman.com/ac.

http://osb-bsf.ic.gc.ca

http://www.rsppr.ru 